Historic, Archive Document

Do not assume content reflects current scientific knowledge, policies, or practices. 

$62,2=62.63$

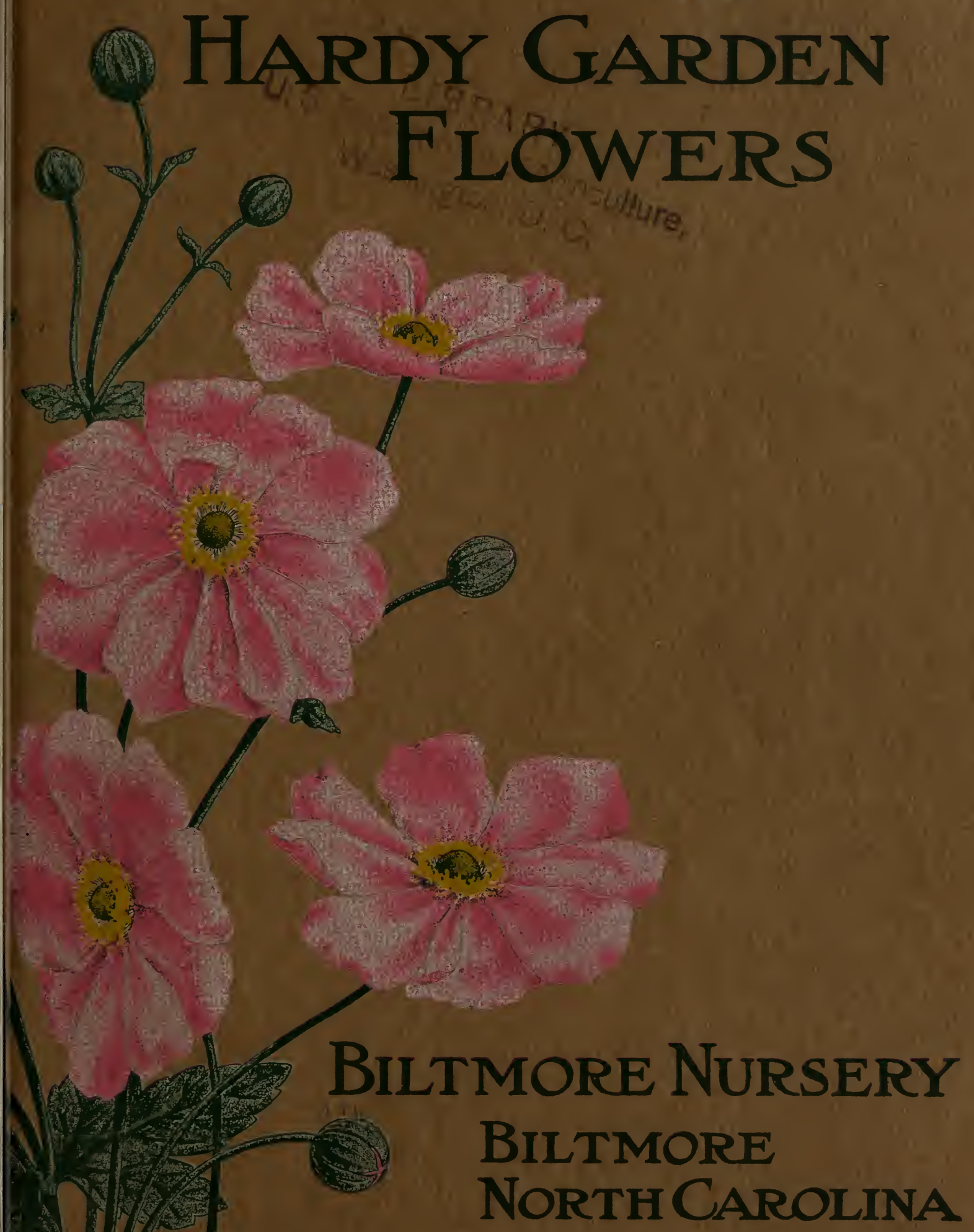




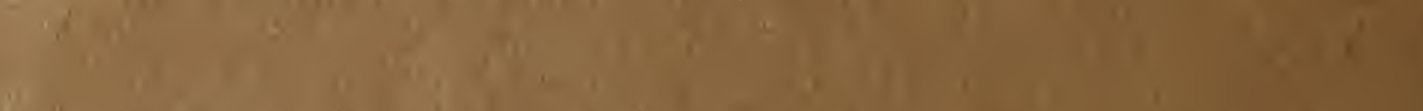
Q

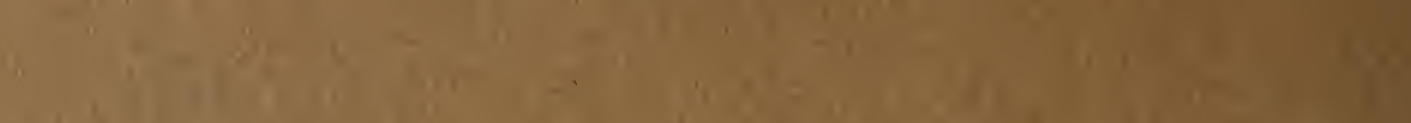

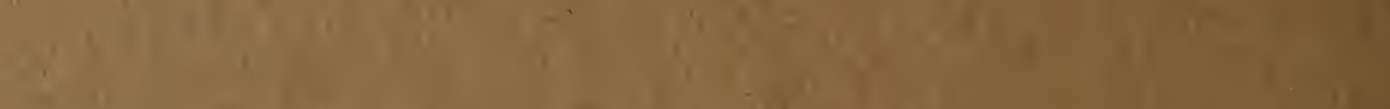

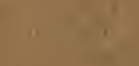

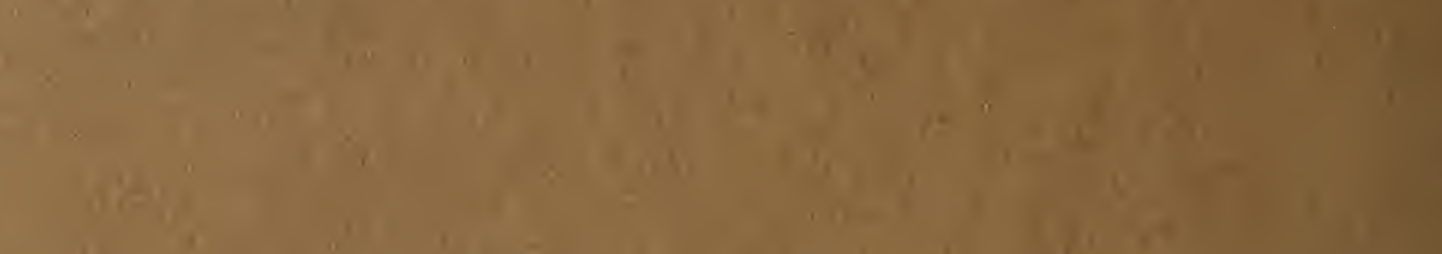

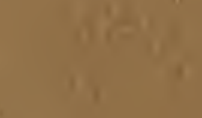

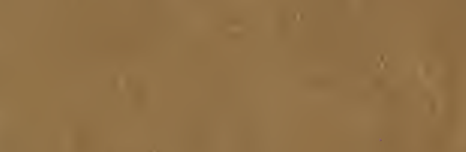<smiles>CCCCCCCCC</smiles>
$+2=$

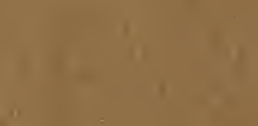
. 


\section{Hardy Garden Flowers}

\section{BILTMORE NURSERY}

BILTMORE, N. C. 


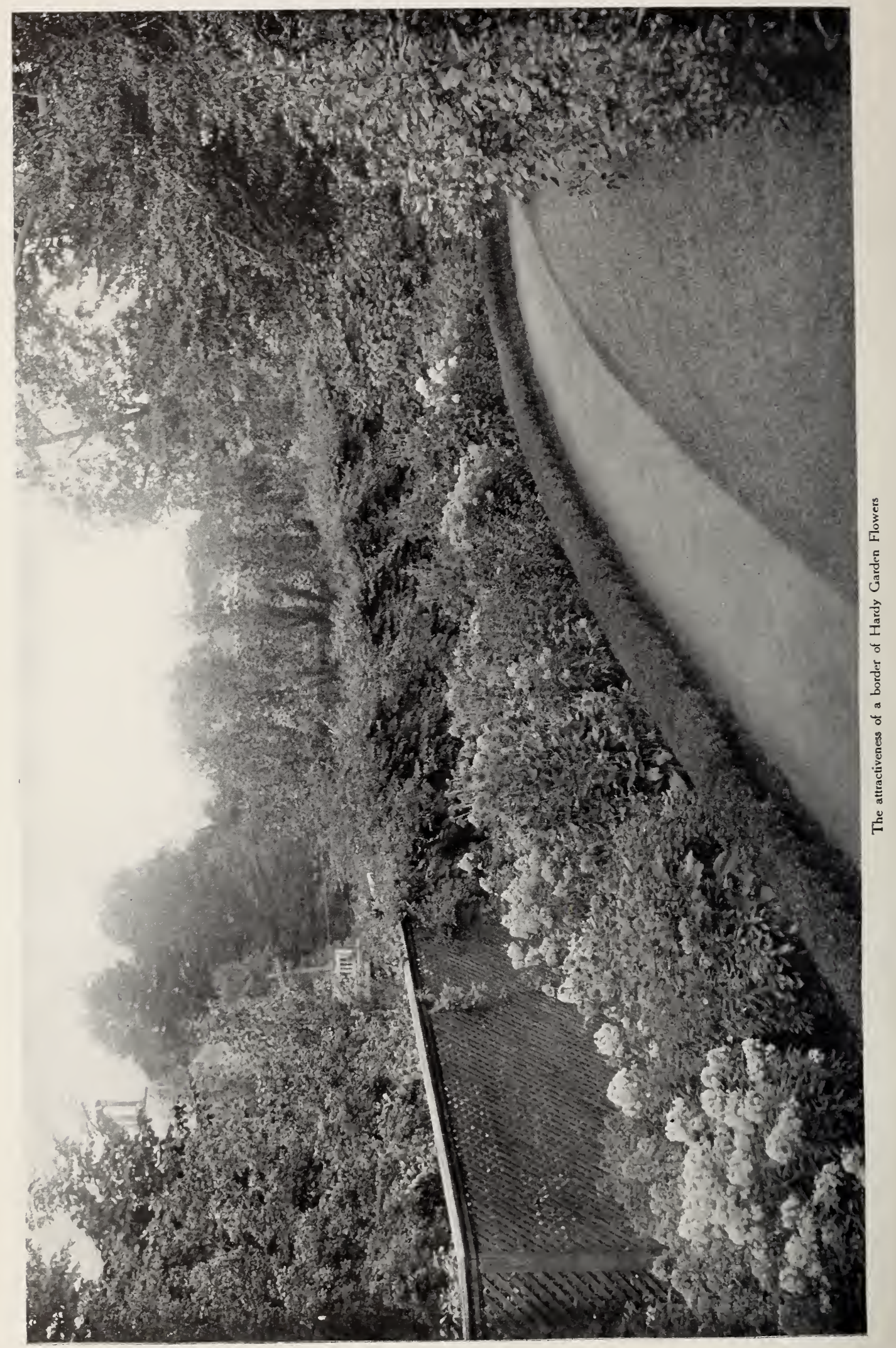




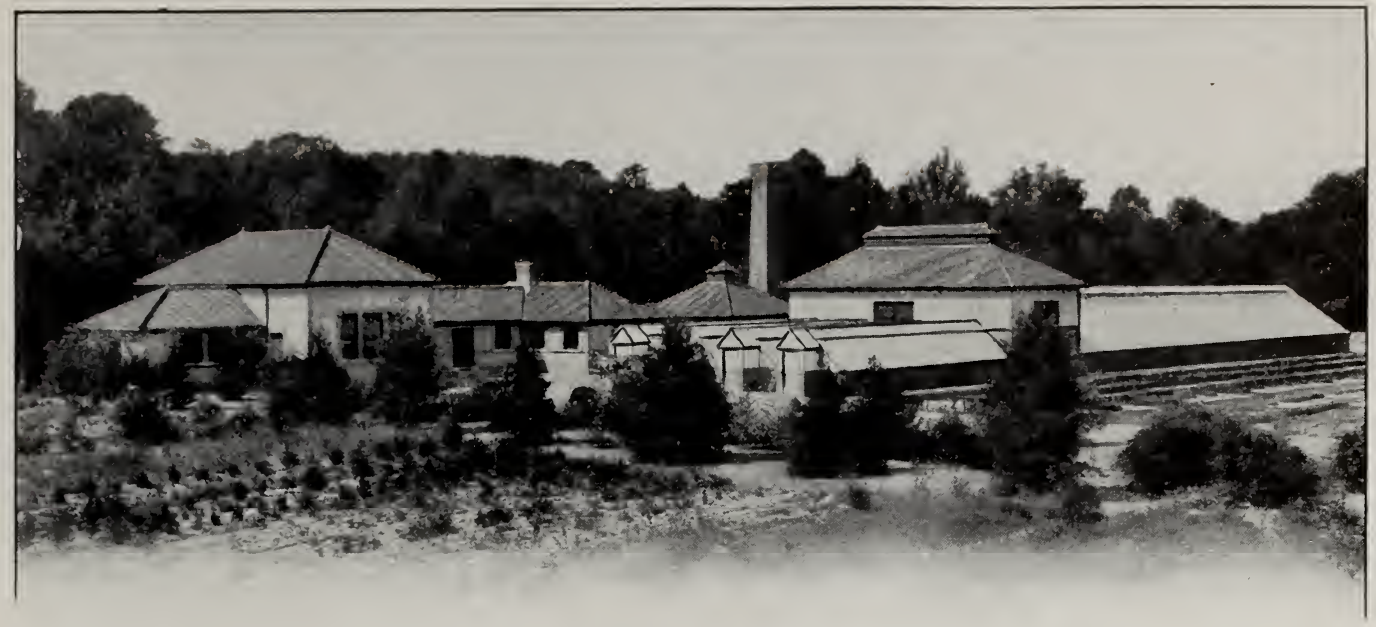

NURSERY BUILDINGS

\section{Introduction}

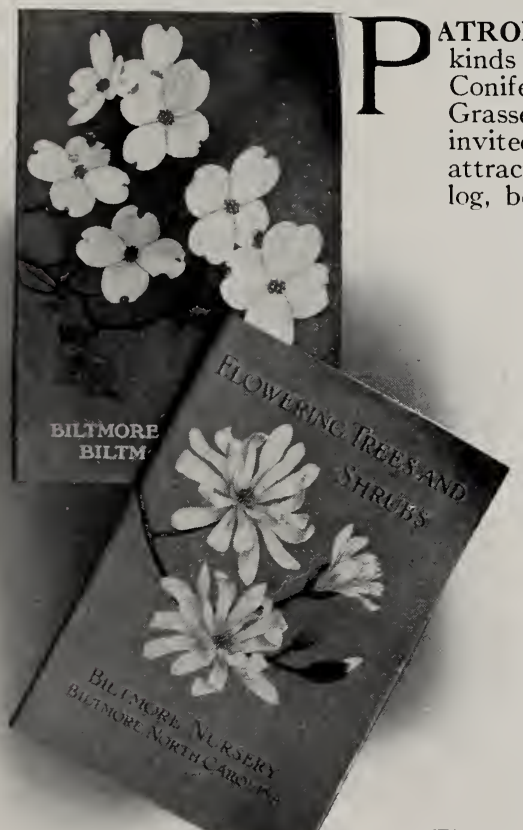

AND PROSPECTIVE BUYERS who are interested in other kinds of plants, such as Flowering Trees and Shrubs, Evergreens, both Coniferous and Broad-leaved; Roses, Shade Trees, Vines, Ornamental Grasses and Bamboos, Aquatic and Bog Plants or Hardy Ferns, are invited to write for any of our catalogs. In particular you should see the attractive booklet "Flowering Trees and Shrubs," or our complete cata$\mathrm{og}$, both of which are replete with pictures and information concerning Biltmore plants. The illustrations opposite show the cover designs of these publications. Free, on application, to any customer or prospective purchaser.

BILTMORE TREES AND PLANTS have been widely sought by discriminating buyers; the demand increasing to such an extent that we have been compelled to more than double our plantations and to prepare unique and attractive catalogs to place in the hands of enquiring friends and patrons who seek the best strains of ornamentals for their lawns and gardens. We appreciate the public confidence and the increasing patronage which has been bestowed upon us, and our efforts to uphold the high standard of our stock have been greatly stimulated by this encouragement.

BILTMORE NURSERY was established in i889. The experience of many years is blended in the production and handling of our plants. We have no connection whatever with any other nursery, and employ no agents, our entire business being transacted from our office at Biltmore, North Carolina.

OUR LOCATION is in the heart of the mountains of Western North Carolina, at elevations between two and three thousand feet above sea-level, where the temperature ranges from ninety degrees above to, in the instance of our higher fields, twenty degrees below zero. The main nursery is located on the northerly bank of the Swannanoa River, near its confluence with the French Broad and between the corporate limits of Biltmore and Asheville. The manager's office is in Biltmore, three minutes' walk from the terminus of the Asheville-Biltmore electric railway, and diagonally opposite the Southern Railway passenger depot. The superintendent's office is at the greenhouses, ten minutes' walk from the end of the trolley line. We invite inspection of our grounds any day except Sunday.

EXTENT AND CAPACITY. Nearly three hundred acres are devoted to the cultivation of trees and shrubs. Our greenhouses and coldframes cover an area of seventy-five thousand square feet, which, in connection with seed-beds to the extent of more than three acres, a large force of trained men and many varieties of carefully tilled soils, give us especial facilities for growing choice trees and plants on an extensive scale both in numbers and kinds.

QUALITY OF STOCK. The variations in temperature peculiar to the Southern Alleghany region, its evenly distributed and bountiful rainfall, and rich but shallow soil, combine to produce a quality of stock remarkably superior in root-formation, thriftiness and hardiness. Biltmore Nursery is inspected annually by the State Entomologist and a certificate pronouncing the stock free from all insects designated as dangerous pests, and apparently healthy in every respect, will be attached to every shipment. We are prepared to fumigate with hydrocyanic gas all or any nursery stock when state laws or customers require such treatment. 
PLANTING PLANS AND HORTICULTURAL QUESTIONS. We are pleased to answer inquiries from friends or patrons concerning what to plant, how to plant, and when to plant. Our experience is at your command. Not only are we prepared to give advice, supply names of trees, shrubs and plants, either cultivated or wild, or to prescribe for plant diseases or attacks of insects, but we will gladly undertake, at small cost, to prepare plans for beautifying the home surroundings, showing a pleasing arrangement of paths and drives combined with an artistic

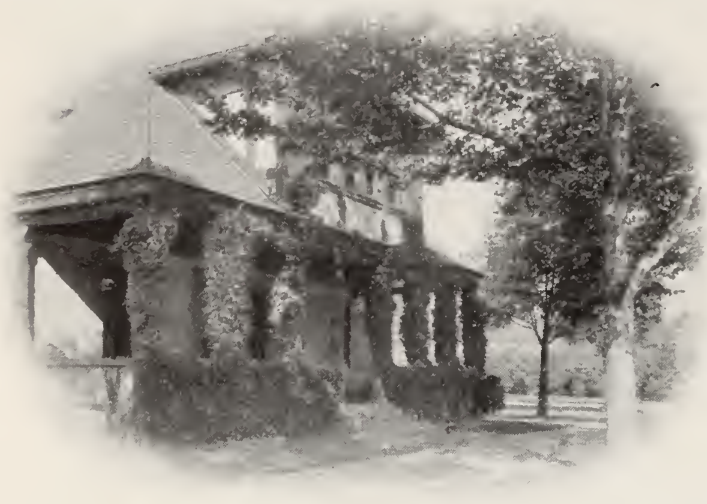

Main office grouping of trees and shrubs.

BILTMORE TREES AND PLANTS are growing from Maine to California and from Canada to Mexico, besides several countries across the seas. From the wording of the descriptions, it is an easy matter to select plants adapted to the local conditions of the average planter, whether it be a !ocality where severe cold reigns in winter, or one where warmer sun prevails.

SHIPMENTS. We have suitable plants of each grade of all the varieties listed. Such plants have been frequently transplanted, are shapely and select specimens, and represent honest values. They may be sent safely to any point having transportation facilities. Prepaid shipments are, of necessity, made up of smaller plants than those traveling at purchasers' expense; but invariably they are robust, well-established field-grown plants, and eminently satisfactory where the inconvenience or expense of heavier shipments is a deterrent. We reserve the right to forward prepaid orders by express or mail, and in the instance of packages weighing in excess of one hundred pounds, to effect delivery by freight.

OUR RESPONSIBILITY. We refer you to any bank or bankers in Asheville, N. C. We guarantee safe arrival and satisfactory condition of all shipments, unless, from the lateness of the season or extreme causes, we write for consent to waive responsibility. We are most careful to have all plants correctly labeled, and hold ourselves prepared to replace, on proper proof, all that may prove untrue to label, or to refund the amount paid therefore; but it is understood that, in case of error on our part, we shall at no time be held responsible for a greater amount than the original price of such plants.

PACKING. The utmost care will be used in digging and preparing the plants for shipment. There are no charges for packing or packing-cases, or for delivery to our freight or express depots, except in the instance of shipments to foreign countries, where the preparation is often an important item of expense.

RATES AND PRICES. The prices quoted in this catalog are net, and apply to unit quantities: but six plants of any one kind will be furnished at five times the single rate, and a dozen plants of any one kind at ten times the price for each plant.

TERMS CASH on or before delivery to forwarding agents. We prefer remittances by Post Office Money Order, Express Money Order, Bank Draft, or in Registered Letter. Money may be sent at our risk if forwarded by any of these methods; but we cannot assume responsibility for any remittance or order that fails to reach us, unless sent as above directed.

PACKING SEASON. We ship from October I to May I, with the usual interruptions during winter.

CARE OF STOCK ON ARRIVAL. Promptly on arrival, the trees or plants should be unpacked and planted, or else the roots should be protected from sun or air by covering with moist earth. If the ground is frozen outside, or the packing material in the cases frozen, store the original package in a cool, moist cellar until the conditions are favorable for handling. Care should be taken in choosing soil and environment, to the end that success may reasonably follow your labors in planting.

CATALOGS SENT UPON REQUEST. We will gladly mail catalogs to any one interested in plants, or to friends in whose hands you would care to place a copy.

TREES AND PLANTS AS ANNIVERSARY PRESENTS. Orders are frequently received from patrons to send plants to special addresses as gifts or anniversary presents, with requests to convey to the recipients the proper form of acknowledgement, and in due time the items of stock selected. All such orders will be most carefully handled, and the plants definitely reserved for forwarding during the planting season.

CONCERNING BILTMORE PLANTS. We are frequently asked if plants grown in the North Carolina Mountains are adaptable to the climatic and other conditions existing in many sections of the country. They are, indeed, peculiarly resistent to changes of environment. Mother Nature develops her sturdiest children on the mountain plateaus, and they carry the vigor of the hills with them when transplanted to the plains and valleys. Experience has shown that trees, shrubs and plants grown in high elevations are remarkably hardy and vigorous when transplanted to lower levels, growing year after year in the new locations with undiminished vigor. A trial order, if nothing more, will result in lasting pleasure. 


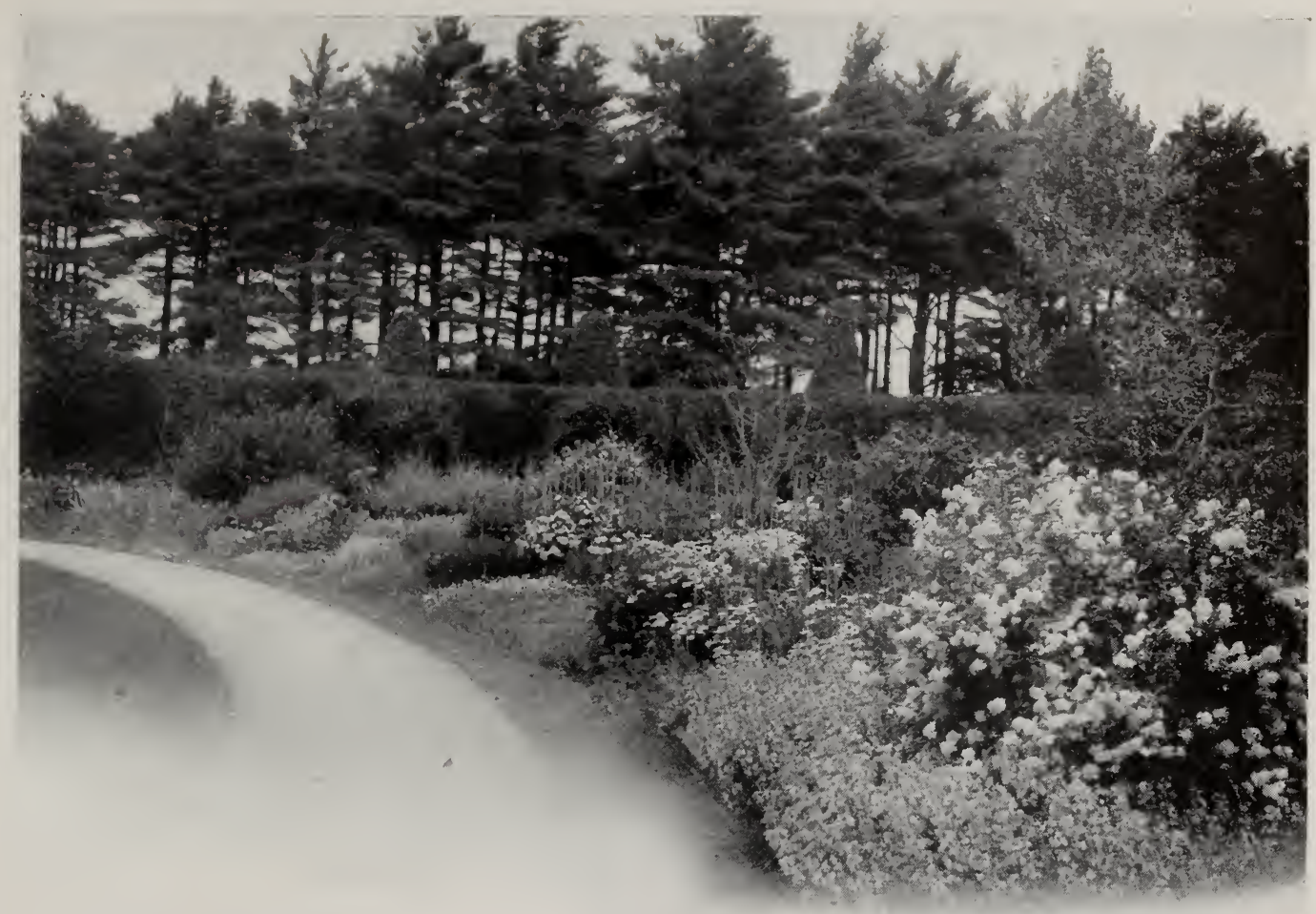

\section{Hardy Garden Flowers}

The spirited and perpetual charm of hardy gardens has won for them wide and intense enthusiasm. While natural and restful in general effect, their beauty is yet ever varying and ever appealing, for flowers may be found in them throughout the season-something new of interest every day. Inspiration for the best work of recent years has come from gardens planted long ago. We have seen them grow into richer, fuller and mellower beauty, instead of fading with time; and how colonies of Hemerocallis or Fraxinella sometimes outlive, on the same spot, three generations of owners. Thus we are learning to take the finer, more enduring old gardens for our models, welcoming back to our borders the drifts of Snow-pinks, the gay Peonies and Hollyhocks, sweet-breathed Day Lilies, brilliant Poppies, the Larkspurs, Phloxes, Irises, and all the year's train of old-time hardy flowers. Yearly we find new uses for them entirely within the bounds of real landscape art, as, for instance, the use of pretty, creeping plants for covering bare spots rejected of the grasses, and the planting of tall perennials among trees and shrubs for life and color during the hot, dull days of midsummer. This reinstatement of Hardy Herbaceous Perennials rejoices the heart of the landscape gardener, for it means his emancipation from petty. futile efforts with tender foreign materials, and a return to broader, freer, more permanent effects with less expensive materials. By this renaissance the heart of the true amateur gardener, with perhaps only a strip of informal hardy border at his disposal, is also made glad, and that of the nurseryman who knows what magic may be wrought with even a few of the better species. tastefully planted.

\section{Acanthus}

Acanthus mollis. BEAR's BREECH. As a crown for its great, handsome leaves that for centuries have been familiar to the world in classic architectural designs, this, the most striking of the Acanthads, has in late summer tall spikes of curious, rose-purple flowers. Rising for 2 feet or more above the deeply cleft, heartshaped leaves, which are about 2 feet long and a foot wide, the flower-spikes give the plant a stature of about

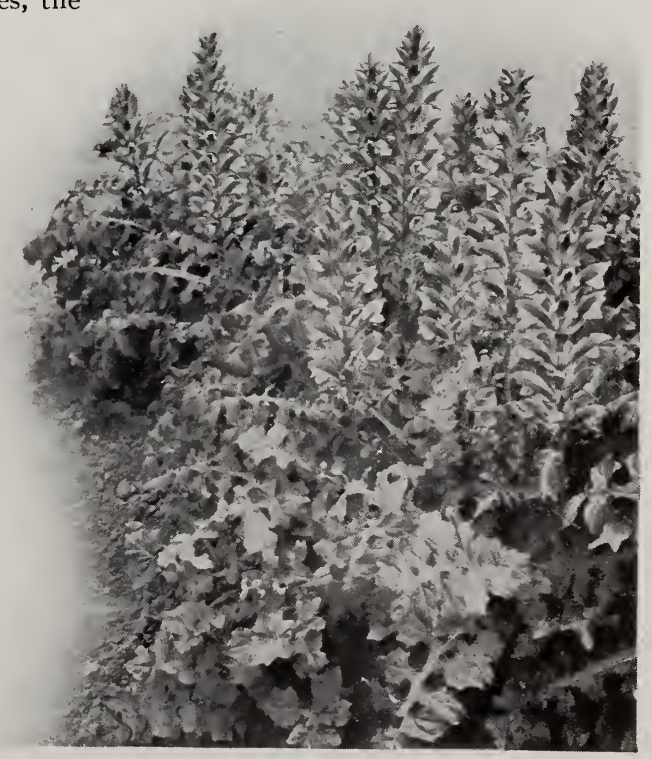

Acanthus mollis 
Acanthus mollis, continued

4 feet and a peculiar tropical stateliness. These odd, showy flowers should be cut away as they fade, in order that the plant's vigor may be kept for a long succession of them and for an undiminished beauty of its leaves, which are velvety in texture and without the objectionable spininess of other varieties. The Acantlus thrives best in full sunshine and a rich, light, welldrained soil; for excess of moisture in winter and spring injures the roots more than cold. In planting isolated specimen clumps, two or three good crowns should be placed near together to give a fine effect the first year. A good mulch of long litter or evergreen boughs is appreciated in winter by clumps newly planted, or by old ones in severe climates. A superb plant for tropical gardening, tall borders and backgrounds. Strong plants, prepaid, $25 \mathrm{cts}$. each; larger sizes, purchaser paying transportation, $25 \mathrm{cts}$. and 35 cts. each.

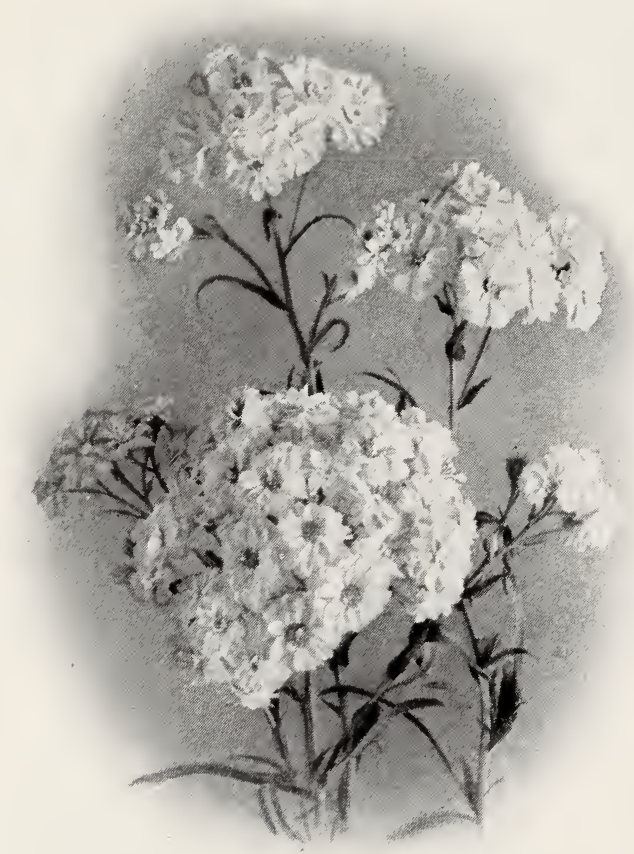

Achillea prarmica, The Pearl

\section{Achillea - The Yarrows}

Among the quaint, old-fashioned Yarrows and Tansies of this group are found some of our very best hardy flowers. The leaves of most sorts are finely cut, often silvery or hoary, with a myrrh-like fragrance. The blossoms grow upon long, slender stems in dense, flattened clusters, keeping up a continual cheery shine of color all summer long. Some white-flowered species are admirable for cutting, as they bloom so prodigally and their branching clusters of dainty blossoms give grace and harmony even to faulty arrangements in the vase and bouquet. The plants grow freely in all soils; dwarf species making thick carpets for dry, sunny places or rockwork, while the tall forms are valuable for wild gardening and borders. All increase rapidly from creeping root-stocks, and quickly form a dense sod.

Achillea eupatorium. FERN-LEAVED YARROW. The neat, finely cut foliage of this species is especially
Achillea eupatorium, continued

pretty; its large clusters of brilliant yellow flowers last in full beauty all summer. 4 to 5 feet.

A. filipendulina. NOBLE YARROw. Of lower growth than the preceding, but unusually vigorous and showy. The dense, flat corymbs of golden yellow flowers are lavished in radiant masses all through the hottest months. 2 feet.

A. ptarmica flore pleno, The Pearl. DOUBLE-FLOWERED White TAxsy. This garden form of the European White Tansy is one of those graceful and spiritual white flowers so constantly needed for cutting without stint to mingle with other blossoms less refined, and one responsive to the need almost all season. Its daintily formed, quite double flowers are borne in long-stemmed, branching sprays so profusely as to give a refreshingly cool, airy effect through summer heat and late into fall. Nothing is better for lighting up a somber spot, or easier to establish in a dry sunny one. In moderately fertile soil the flowers are about half an inch across, on stems from I to 2 feet high.

A. tomentosa. WOOLLY YARROW. An oddly attractive little plant, perhaps the most useful of the dwarf species, as it spreads a thick carpet of handsome, deeply cut, down-whitened leafage over rockwork and dry, sunny slopes. The bright yellow flowers are most abundant in June. 8 to 12 inches.

Any of the Achilleas, strong plants, prepaid, $15 \mathrm{cts}$. each; larger sizes, purchaser paying transportaion, 15 cts. and 25 cts. each.

\section{Aconitum - The Monk's-Hoods}

On account of their odd shapes and rich, peculiar shades of blue, the Monk's-hoods are always striking and interesting. With their petals curved into such quaint hood and helmet shapes they are really the "blue bonnets" of the garden, beneath which impish or fairy faces are less difficult to imagine than monkish ones. Irregularly arranged in tall, clustered spires of bloom, they give a wonderful display of millinery through summer and fall, often persisting in beauty until snow falls. Another valuable characteristic of these plants is that they grow well in shade, and thus may be planted under tall trees which protect them from frost, so that bright, perfect flower-spikes can frequently be gathered in November.

Aconitum autumnale. Autumn Aconite. From September until pitiless cold the showy b'ue or lilac flowers of this species cluster on branching pyramidal spikes from 3 to 5 feet tall. One of our richest and freest blooming autumn plants.

A. napellus. MoNk's-HooD. Taller, often growing 5 or 6 feet high, with flowers in a number of darker. more intense shades of lavender-blue, set more thickly along branching spikes that appear a month or two earlier. This is one of the easiest sorts to establish and multiplies very fast. Every year a quantity of new tubers is formed around the older ones, so that, to obtain the finest flower-spikes, division every few years is necessary. A species that endures shade especially well and blooms for a long time; its spikes last well in water and are favorites for cutting.

Either of the above, strong plants, prepaid, 25 cts. each; larger sizes, purchaser paying transportation, 25 cts. and $35 \mathrm{cts}$. each.

\section{Adonis}

Adonis vernalis. PHEAsANT's Eye. One of the very early and cheery spring plants that blooms with the Snowdrop and Crocus. An advantage over its early associates is given by the dense mound of delicate, feathery leaves that form so fine a foil for the large, glowing yellow flowers tipping every branchlet. These are from 2 to 3 inches across and shaped much like Anemones. The plants grow from 8 to 12 inches tall, according to soil and latitude; in coldframes it is easy to flower them for St. Patrick's day. Planted in light, 

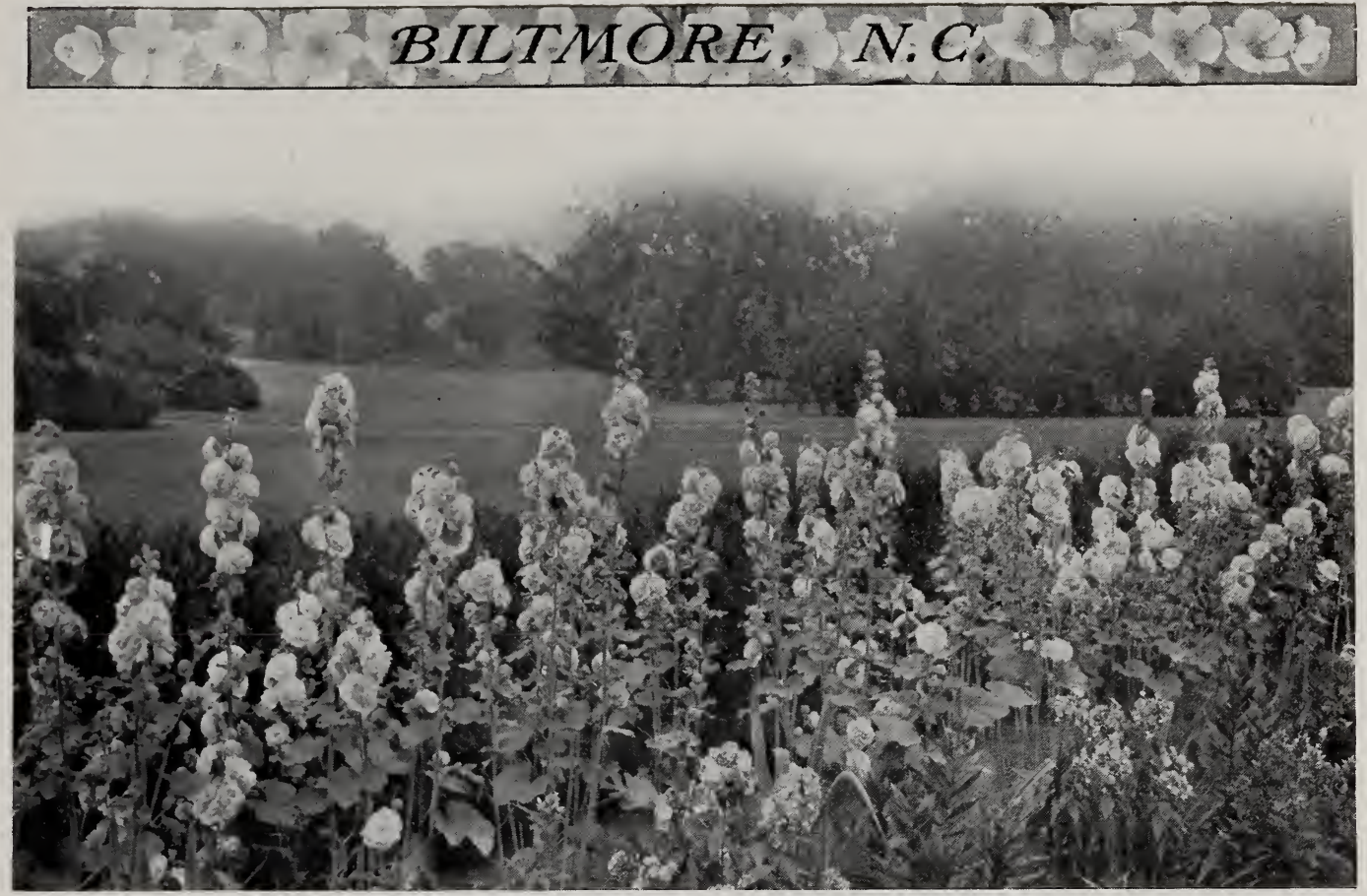

Hollyhocks should be seen in long rows to exhibit the most striking effect

Adonis vernalis, continued sandy soil in sunny borders or nies that grow on happily for years. A "good luck" symbol in Japan. One of our choicest spring flowers. Strong plants, prepaid, 25 cts. each; larger sizes, purchaser paying transportation, 25 cts. and 35 cts. each.

\section{Agrostemma $\cdot$ Rose Campions}

The following species of Agrostemma, sometimes classed as Lychnis, are among the best known of the old hardy garden flowers. Sun-loving, gay-flowered, stout and erectgrowing, they are always conspicuous and admired from the contrast of their brilliant blossoms with their downy white foliage. Gayest in June and July.

Agrostemma coronaria, MULLEIN PINK. The large, rosy crimson flowers are $\mathrm{I} / 2$ inches across, curiously fringed at the throat, circular in outline, and borne at the tips of branchlets on stems I to 2 feet tall. A good old border plant, sturdy enough to flourish even under trees.

A. flos-jovis. FI,OWER OF JOVE. Not so striking, because of its lower growth, but quite charming in its way. The leaves grow in a close rosette about the root the flowers, on stems 12 to 18 inches high, are bright red or rose, about $1 / 2$ inch across and
A grostemma f1os-jovis, continued clustered in dense umbels held well up above the foliage. Either of the above, strong plants, prepaid, $15 \mathrm{c}$. each; larger sizes, purchaser paying transportation, $15 \mathrm{cts}$. and $25 \mathrm{cts}$. each.

\section{Ajuga}

Ajuga reptans. Bugle VINE. A pretty little creeping plant with blue flowers shaped like bugles and borne in spicate whorls. The glossy leaves and fast-spreading stems form a fine setting for the flowers, which embroider the low, dense vine quite thickly in early summer. Excellent for rockeries and edgings and for carpeting shaded slopes where grass will not grow, as it maintains a bright green sod the year round. Strong plants, prepaid, I5 cts. each; larger plants, purchaser paying transportation, 15 cts. and $25 \mathrm{cts}$. each.

\section{Althaea - Holly- hocks}

Althaea rosea. HOLLYHOCKs. Among the very finest of old hardy garden plants the Hollyhock still holds a proud place and may be termed one of the great powers of July. It has the largest llowers and widest range of colors among tall garden plants, combined with vigor, hardiness, noble aspect and stately beauty. In his charming book, "The Garden's Story," George El1wanger says of it: "Classed usually as a biennial, it might come under the head of perennials, being as permanent as 


\section{Q BILTMORE NURSERY TWE}

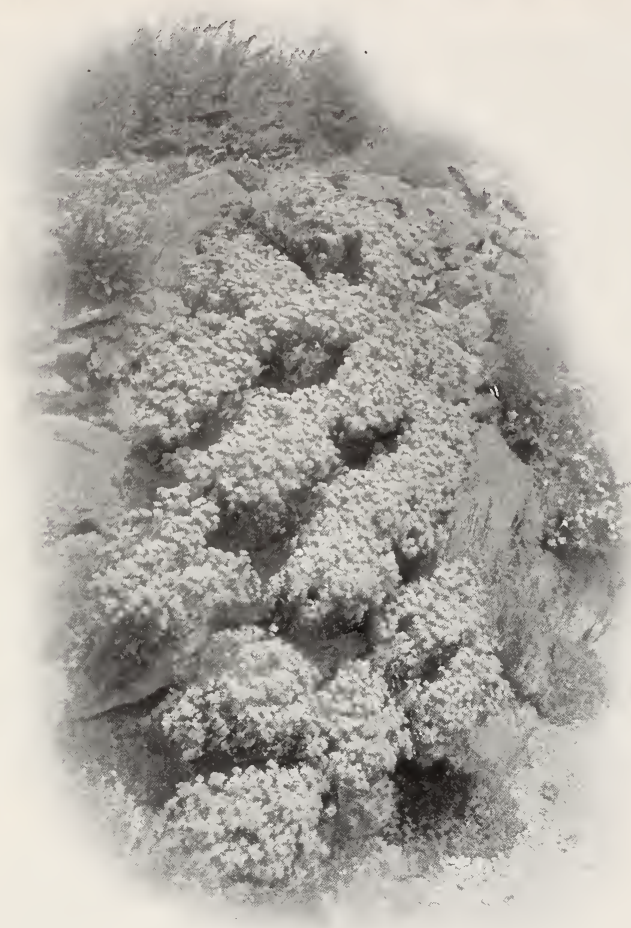

Alyssum saxatile compactum

Althaea rosea, continued

many true perennials. It should be seen in long rows in well-drilled color columns to exhibit the most striking effect, each plant a sentinel in uniform, and each with rosettes brighter than his fellows. The Hollyhock will grow anywhere; it will grow doubly well with deep cultivation and when liberally manured and watered during dry weather." Under favorable conditions the plants grow from 6 to I2 feet high, the large, funnel-shaped flowers of their tall spikes measuring 4 to 5 inches across. From deep, velvety crimson-black through shades of red, rose and scarlet, both soft and brilliant, the colors reach cream-white and pearl-white; there are also exquisite tints of canary and lemon-yellow. While the single-flowered varieties are accounted hardiest and most artistic, the double sorts last longer. Both are admirable as a background for tall borders. Frequent renewal is necessary in localities where the rust infests old plants. Spraying the plants while still young with a weak solution of permanganate of potash is a preventive of the latter in its incipient state. Strong plants, prepaid, I $5 \mathrm{cts}$. each; extra-large plants, purchaser paying transportation, I 5 cts. and 25 cts. each.

\section{Alyssum}

Alyssum saxatile compactum. GoLD TUFT. A mat of the fragrant, golden yellow flowers of this choice little creeping perennial gives to the garden very early in spring one of its sumniest touches. In less than a year single plants will easily cover a square foot of earth and produce many hundreds of compact little yellow flower-heads. The greyish foliage remains fresl through winter if the plants are in a dry, open position and thus it is best used as an edging, border, or rockery ornament. Strong plants, prepaid, I5 cts. each larger sizes, purchaser paying transportation, I5 $\mathrm{cts}$ and $25 \mathrm{cts}$. each.

\section{Amsonia}

Amsonia tabernaemontana. A plant so shrub-like in its appearance that it is frequently planted among low shrubs or in front of tall ones. Leaves and stems are light green and resemble those of a willow; the starlike, lavender-blue flowers are borne in terminal cymes and are delicately pretty. The root is so vigorous that a fine clump is soon formed. 2 feet. Strong plants, prepaid, 5 cts. each; larger sizes, purchaser paying transportation, $15 \mathrm{cts}$. and $25 \mathrm{cts}$. each.

\section{Anchusa}

Anchusa italica. Italian Alkanet. A tall, interesting perennial of tropical appearance, with large, rough, shining leaves above which great terminal heads of deep blue flowers are produced from June to September. It makes a good border plant and is also at home among shrubs. Vigorous, sun-loving, 3 to 5 feet high. Strong plants, prepaid, 25 cts. each ; larger sizes, purchaser paying transportation, $25 \mathrm{cts}$. and $35 \mathrm{cts}$. each.

\section{Anemone - The Windflowers}

In a soil rich and moist, but well drained, and an open, sunny situation, the Anemones spread rapidly from underground rootstocks and are easily established in large colonies that glorify their garden space and give myriads of exquisite flowers for cutting. For the latter use their long, slender yet wiry stems, airy poise and perfection of outline give them unusual value. The leaves grow in dense tufts from the base of the flower-stems.

Anemone canadensis ( $A$. pennsylvanica). CANADIAN WINDFLower. From June to midsummer this, the prettiest of our native Windflowers, is bright with a profusion of starry white blossoms, swaying on slender stems a foot or more in height. The leaves are

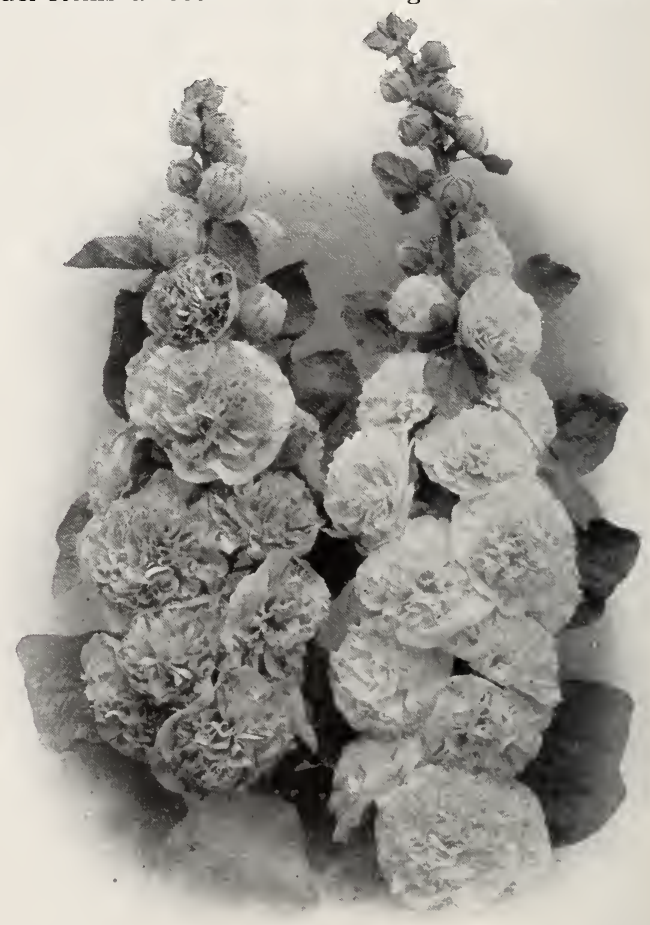

Althaea rosea, Double Hollyhock 


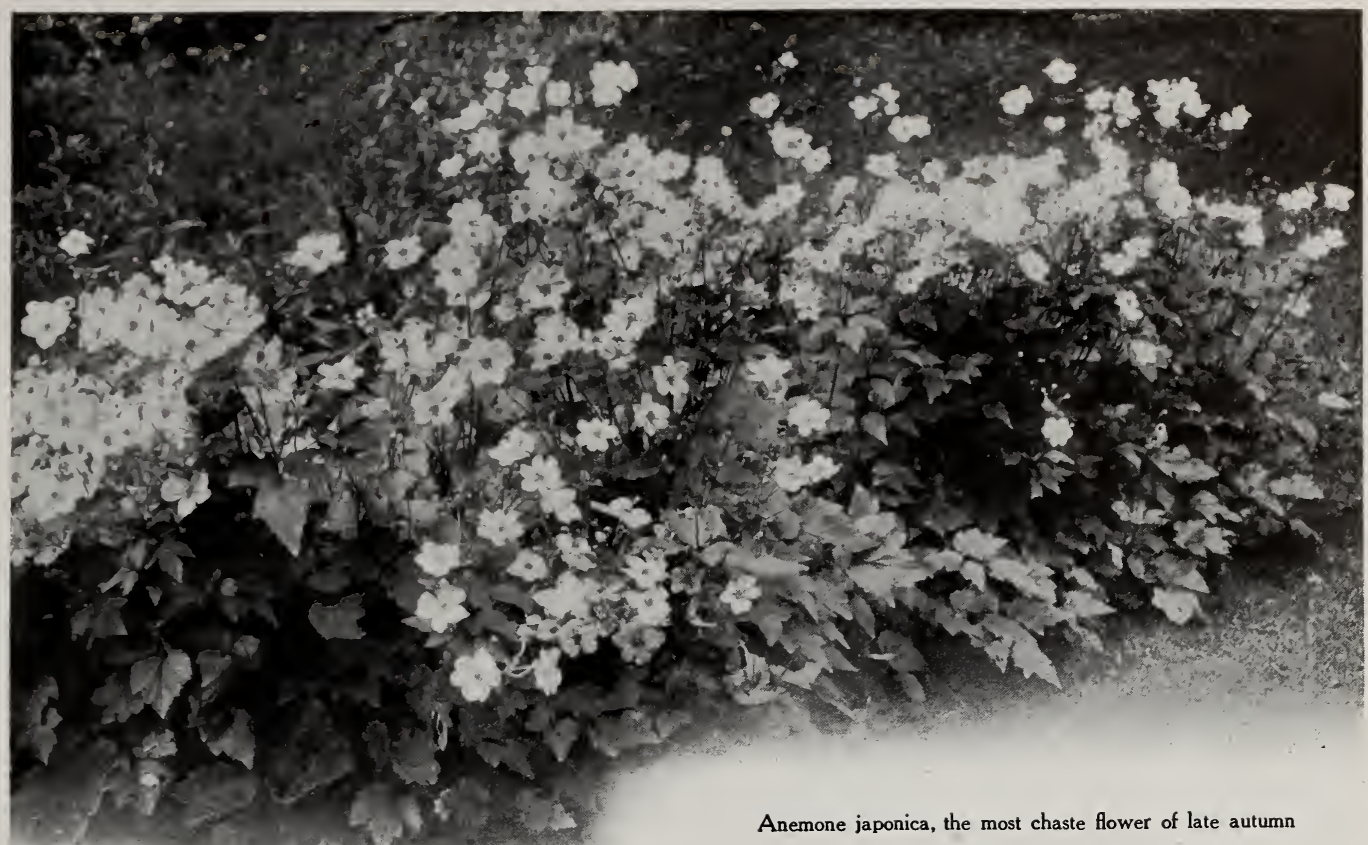

\section{Anemone, continued}

Anemone canadensis, continued

long-petioled and quaintly cleft. The blithe beauty of the flowers, together with the plant's quick growth, hardihood and faculty of growing happily in sun or shade, make it valuable for a ground cover in the shrub border, or for colonizing in open, moist woods. Strong plants, prepaid, I5 cts. each ; larger sizes, purchaser paying transportation, $15 \mathrm{cts}$. and $25 \mathrm{cts}$. each.

A. japonica. JAPANESE WINDFLOWER. The enthusiasm with which this Anemone was first hailed has been well sustained through many seasons of wide testing. Its different varieties are freely planted for mass effects, for grown singly their full beauty is not appreciated. There is an elegance and distinction about them not achieved by Chrysanthemums and other late flowers. They begin to bloom earlier than Chrysanthemums and continue until heavy frosts stop growth, lighting the waning garden with new life and color. From every joint in their tall, branching flowerstems many buds are produced that open out in uninterrupted succession day after day, making it possible to cut rich sheaves of the blossoms from a good strip of border almost daily. The first flower-stems of a newly set colony may not be more than a font high, but the moist, cool weather of late summer eventually sends them up to a height of 3 or 4 feet. The leaves also, which in this group are particularly handsome, resembling somewhat those of the grape when seen from a distance, grow broader and darker with the advancing season. Japanese Anemones like a rich. moist soil and open situation. Prepare the ground deeply before planting and topdress annually.

Alba. The most chaste flower of late autumn; Madonna-like in stateliness, perfection of outline and snowy purity of petals. A thick circle of golden yellow stamens lights the center of the flower. Cool nights only seem to give its petals a more satiny whiteness; in places where they can thaw gradually the blossoms sometimes recover fully after heavy frosts. Quite lasting as a cut-flower.

Lady Ardilaun. In this variety the petals are somewhat broader and thicker, overlapping each other and forming great blooms of dazzling white.

Prince Henry. Notably rich and showy in effect. The blossoms are quite large, full-double and of a deep, bright pink color. Extra free-flowering and one of the brightest.
Queen Charlotte. A charming sort, with semi-double flowers of fine size and graceful poise, softly flushed with silvery pink.

Whirlwind. This pioneer of the semi-double sorts is still one of the best. Its large flowers, decked with several rows of glistening petals, are produced as freely as those of single varieties.

Any of the Japanese Anemones, strong plants, prepaid, 25 cts. each; larger sizes, purchaser paying transportation, $25 \mathrm{cts}$. and $35 \mathrm{cts}$. each.

SPECIAL OFFER. A collection of three Japanese Anemones, no two alike, our selection of varieties, thrifty plants, prepaid, $60 \mathrm{cts}$; larger sizes, purchaser paying transportation, $60 \mathrm{cts}$. and $85 \mathrm{cts}$.

\section{Anthemis}

Anthemis nobilis. Chamomile, Like most plants of the great group of Composites, the different species of Anthemis are soldier-like in their endurance of heat, drought, cold and other untoward conditions. They form mounds of delicate feathery foliage that is pleasantly fragrant when stirred, and are beautiful even when flowerless. This species has small white blossoms-the medicinal ones of commerce-from July to September.

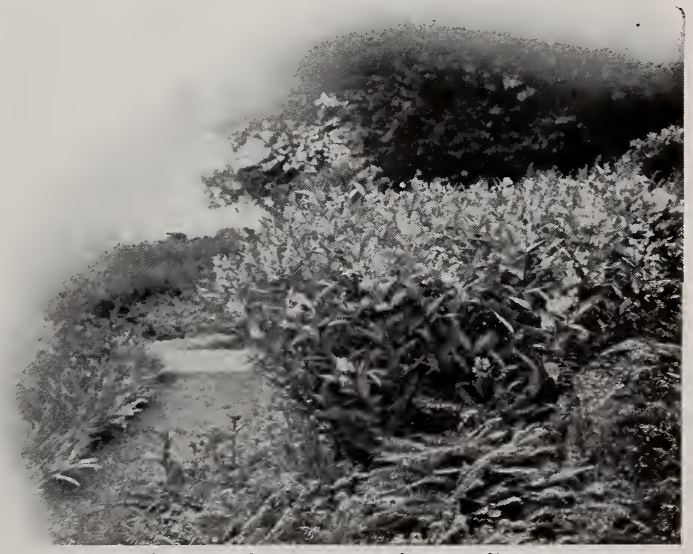

Amsonia tabernaemontana (see page 8) 


\section{BILTMORE XURSERY}

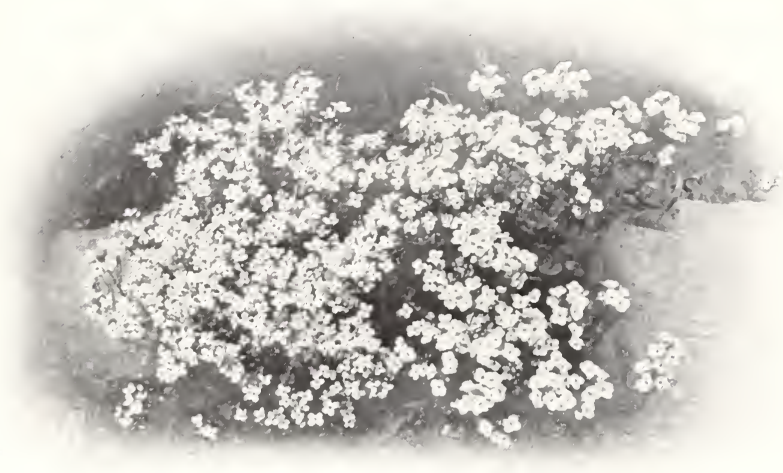

Arabis alpina (see page 11 )

Anthemis, continued

A.tinctoria. HARdy Goldex MARguerite. Taller and showier, with innumerable bright yellow, daisylike flowers, from I to 2 inches across, glittering against the delicate leaves a!l summer long. It is useful for cut-flowers, for borders and even for dry banks, but in more fayored situations blooms much longer, sometimes into November.

Either of the above, strong plants, prepaid, $15 \mathrm{cts}$ each; larger plants, purchaser paying transportation, 15 cts. and $25 \mathrm{cts}$. each.

\section{Anthericum}

In their style of flowering the Anthericums are like miniature Lilies, pure white within and greentipped without. They have hardy, tuber-like rhizomes more permanent in character than those of most Lilies. The leaves all cluster above the root and are grass-like in appearance; from the center, flower-stems a foot or two high spring up in early summer. The species below are natives of middle Europe and by their popular names recall the lifesaving monks of the Alps. In border culture mulch with leaves or litter in winter and give plenty of water when in bloom.

Anthericum liliago. ST. BERNARD's LILy. A pretty, graceful plant abont 15 inches tall, with branching spikes of dainty white flowers in Mlay and June.

A. liliastrum. ST. BRUNo's Lily. Tal!er than the preceding, about 2 feet high, and blooms longer, sometimes from May to August. Both plants furnish a quantity of flowers that are exquisite for cutting. This species is sometimes classed under Paradisea.

Either of the above, strong plants, prepaid, $15 \mathrm{cts}$. each; larger sizes, purchaser paying transportation, 15 cts. and $25 \mathrm{cts}$. each.

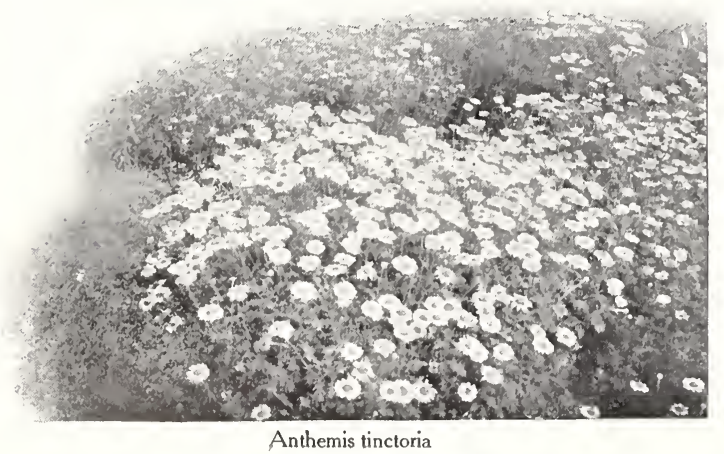

Aquilegia $\cdot$ The Columbines

This is an especially attractive and picturesque family of flowers, combining elegance of foliage and habit with delicately or vividly bright colors in blossoms of bird-like poise and piquant shape. Throughout their bloom. ing season, hummingbirds hover persistently over these curious little "fluted cups and horns of honey." People who like to make collections of all the best varieties of a handsome plant-race will find this one unusually interesting. It is most showy during spring and early summer, but some varieties scatter blooms through the season. Columbines are among the very best plants for borders and rockeries; fine, also, for planting among lilies, to hide the bare stems of the latter with a wealth of pretty leafage. They like spots somewhat sheltered, but sunny, with sandy soil and good drainage.

Aquilegia caerulea. Rocky Mountan Colmanine. Perhaps the loveliest of the large-flowering species:

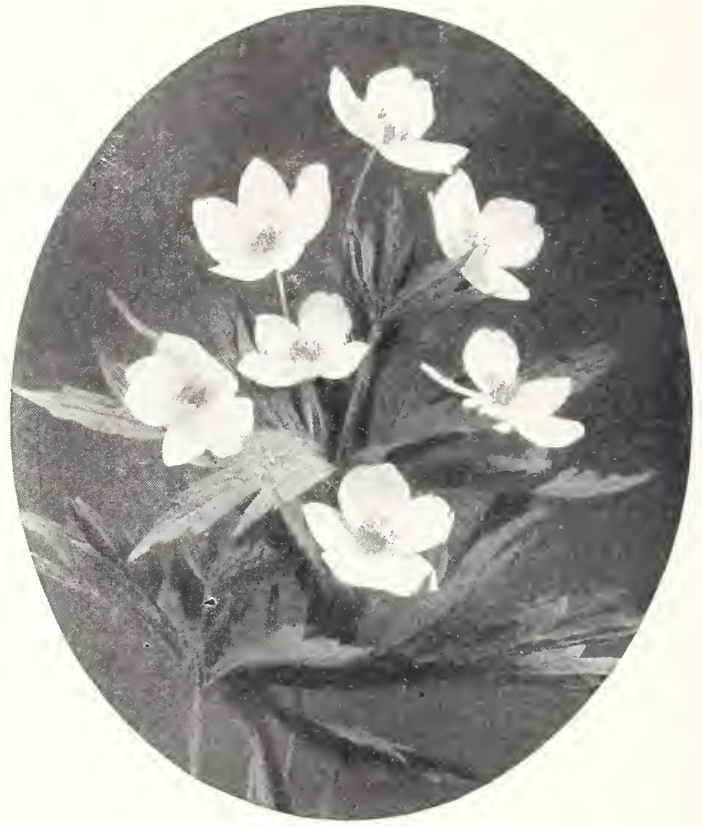

Anemone canadensis (see page 8 )

very distinct in color and habit. Both sepals and petals spread widely, forming flowers about 2 inclies across and very erect. The sepals vary from sky-blue to deep blue; the petals are white or cream-color. The plant grows from is to is inches tall and blooms from May to July:

A. canadensis. AMeriC.IN RED Colunine. Gay, nodding flowers, with yellow cups and scarlet spurs. The tender voung growth of filmy foliage is also tinged with red. The stems are much branclied and from i to 2 feet high. One of the earliest-flowering species, glinting in brilliant patches of color among our gray mountain boulders in April and May.

A. chrysantha. GOLD-SPuRren Columbine. This tallest of all the species grows from 3 to 4 feet high and is lavish of its heautiful flowers all summer, even into September. The blossoms are of fine size, with marvelously long and spreading spurs; the color varies from pure, light primrose to canary-yellow, sometimes tinted with red or claret on the sepals. 


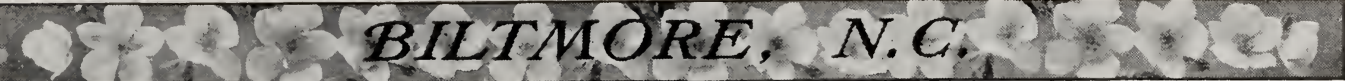

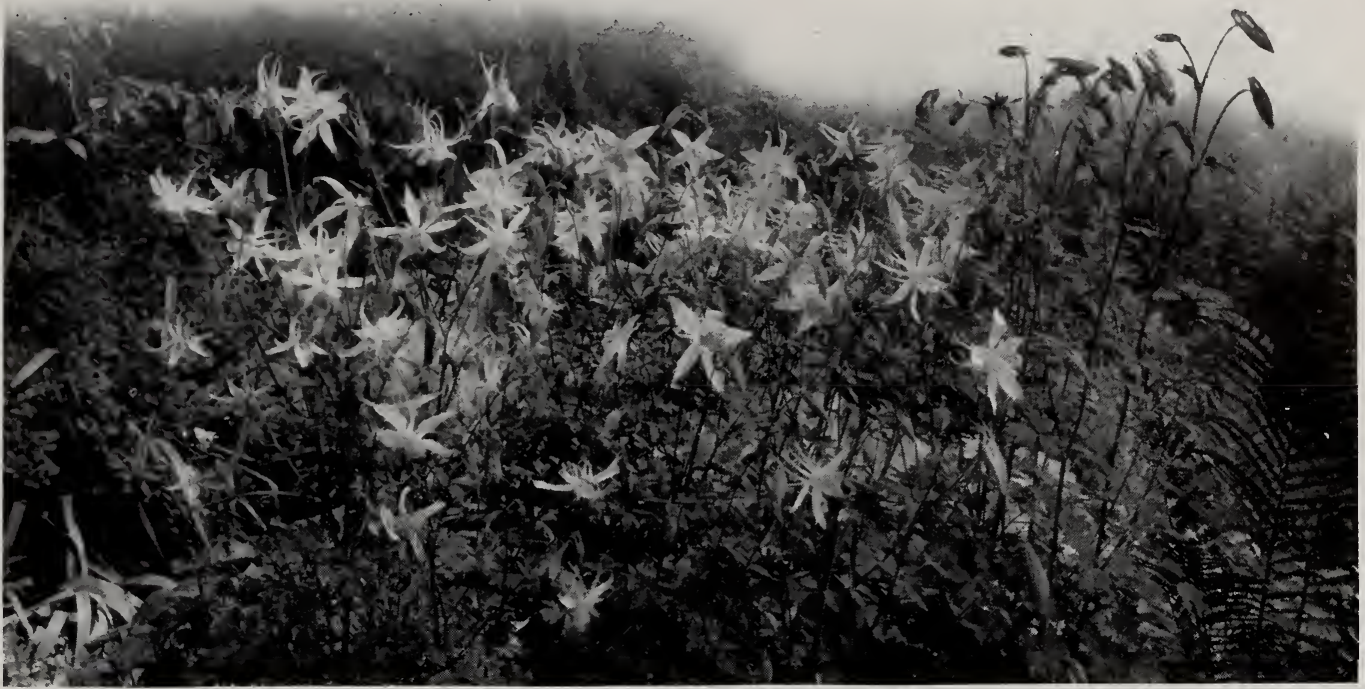

Aquilegia, with " fluted cups and horns of honey"

Aquilegia, continued

Aquilegia vulgaris. EUROPEAN COLUMBINE. A robust and variable species, with flowers in several pretty shades of purple, blue and violet; sometimes almost white. Branching and free-blooming in habit; 18 to 24 inches high.

Any of the Columbines, strong plants, prepaid, $15 \mathrm{cts}$. each; larger plants, purchaser paying transportation, $15 \mathrm{cts}$. and $25 \mathrm{cts}$. each.

SPECIAL OFFER. One each of the four Columbines, strong plants, prepaid, 50 cts.; larger sizes, purchaser paying transportation, 50c. and $85 \mathrm{cts}$.

\section{Arabis}

Arabis alpina. Rock CREss. This pretty creeping plant is an evergreen and a native of Switzerland, where it blooms in March. Its showy, clear white flowers are about $3 / 4$ of an inch across and, in our climate, borne quite thickly on long-stalked, loose corymbs through spring and early summer. It is perfectly hardy and thrives well in any situation except a damp, shaded one. In addition to its ordinary uses for edgings and rockeries, there is now a great demand for it for carpeting beds of spring-flowering bulbs. Strong plants, prepaid, I5 cts. each ; larger sizes, purchaser paying transportation, $15 \mathrm{cts}$. and $25 \mathrm{cts}$. each.

\section{Armeria}

Armeria maritima. SEA THRIFT. A charming little edging or border plant that carpets the ground thickly with low, even tufts of bright green foliage all the year. Almost continuously from early spring until late in autumn these green cushions are gayly stud-
Armeria maritima, continued

ded with many dense heads of rosy pink flowers carried stiffly erect upon wiry stems about 9 inches high. The plant grows thriftily almost anywhere. It is native to seashores and valuable there. Its evergreen, sod-like habit makes it useful for borders and rockwork, or for use in the foreground of taller plants. One of the cheery, dainty little blossoms needed more plentifully in our grounds to give them a more happy expression. Strong plants, prepaid, I5c. each; larger sizes, purchaser paying transportation, $15 \mathrm{c}$. and $25 \mathrm{c}$. each.

\section{Artemisia}

Artemisia abrotanum. SOUTHERNwOOD. The fragrant herbs of oldfashioned gardens are among our pleasantest and most clinging memories of them. Sometimes they were grown in little "herb plots," in sunny corners; sometimes each one had space of its own, or was used for "filling in" among the shrubbery. The more fragrant and permanent sorts that endured persistent cutting-back were grown as an edging to flower beds and along walks where every breeze that stirred their leaves scattered perfumes through house and garden. The Southernwood lias delicately cut leaves of
ravish green, with a spicily aromatic odor, and heads of creamy white or yellow flowers. Its 2 or 3 feet of stature give it the entrée among shrubs, but yield obligingly to the shears when the plant is grown as an edging. Other fragrant herbs are described under Achillea, Anthemis, Asperula, Lay-
Aquilegia cærulea 


\section{BILTMORE NURSERY X N}

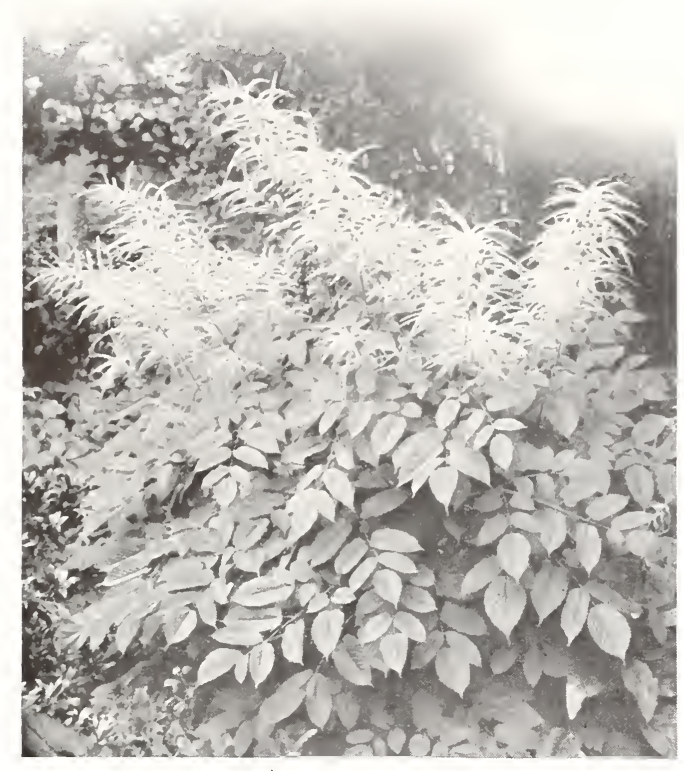

Aruncus aruncus

Artemisia abrotanum, continued

andula, Tanacetum, Thymus and Valeriana-enough to gratify almost any individual preference in filling scent-bags for linen closets and chests, or for making delightfil the garden. Strong plants, prepaid, I5 cts. each: larger sizes, purchaser paying transportation, 15 cts. and 25 cts. each.

\section{Aruncus - Goat's Beard}

Of all the many plants once popularly called Spireas, the groups Aruncus, Astilbe and Ulmaria are much the most attractive. The different species of Aruncus are particularly handsome. Given room and time to establish themselves, they become fine, broad clumps of light and graceful leafage crownec. through June and July with tall, sweeping plumes of delicate white flowers. They grow in any ordinarily good soil, but succeed best in one that is

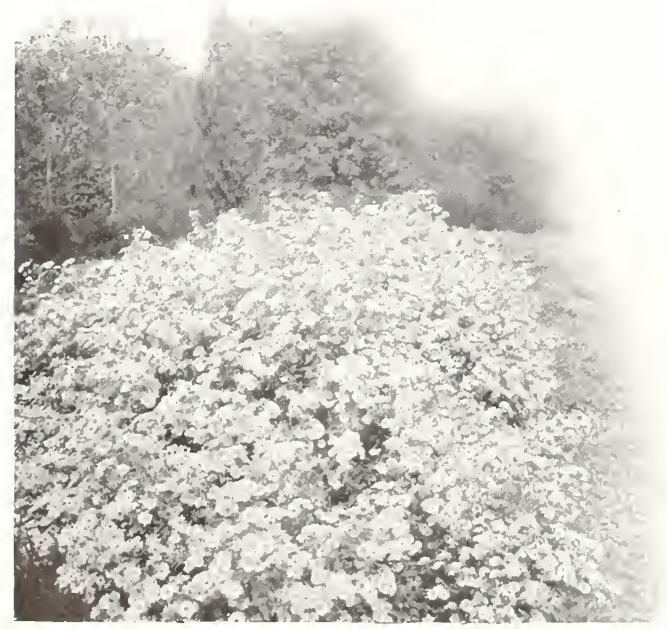

The staceful Hardy Asters (see page 14)
Aruncus, continued

moist and partially shaded. A rainy season that discourages other plants shows the Aruncus at its best keeping its rather sensitive foliage full and fresh. As border plants, this group has both beauty and distinction. Grouped with the species of Iris that bloom near the same time they are always greatly admired For wild gardening nothing could be better, while for cutting, the creamy white, half-curling sprays of some species are ideally beautiful.

Aruncus aruncus (Spircea aruncus; Aruncus sylves ter). GOAT's BEARD. Quite stately, carrying its great branching flower-panicles on 3- to 5 -foot stems. The sprays are more informal, curling and lighter in effect than those of the following species, falling in fluffy rings over the leaves, which are pinnate and of a particularly bright, fresh green.

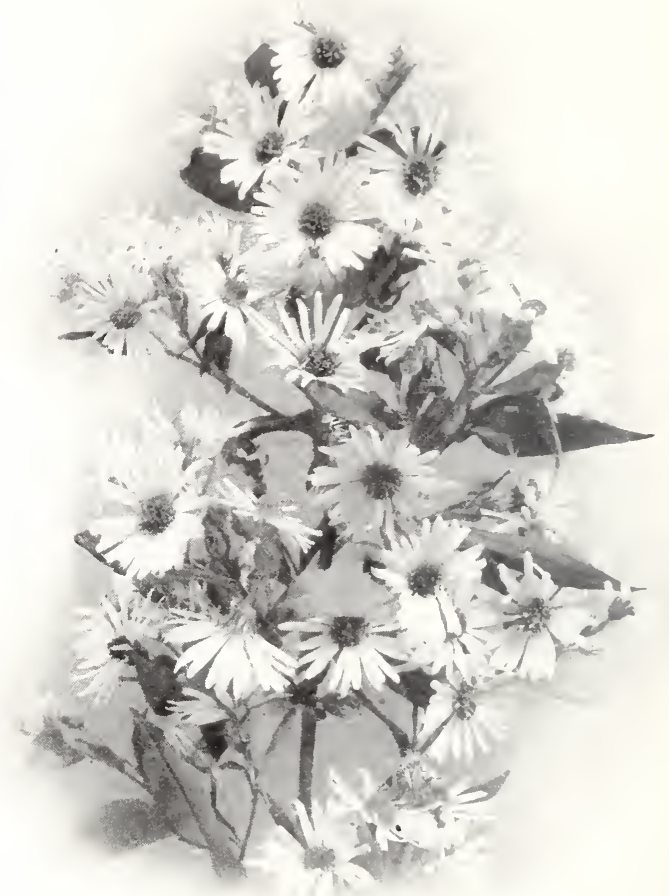

Aster puniceus (see page 14)

A. astilboides (Spirea astilboides). J.IPANEsE Goit's BEARD. Those who find the beatitiful Astilbe japonica difficult to grow should try this plant, which greatly resembles it but is smaller and less exacting. It is also denser and more compact in growth than the true Goat's Beard. The leaves are dark green, serrate and thrice pinnate, the clustered stems about 2 feet tall, with a plumy white crest of large, graceful flowerpanicles.

Either of the above prepaid, 15 cts each; larger plants, purchaser paying transportation, $15 \mathrm{cts}$. and 25 cts. each.

\section{Asclepias}

Asclepias tuberosa. BuTterFLy IVFED. Through spring and early summer this Asclepias, which, next to the Cardinal Flower, is perhaps our most brilliant native plant, is quite unassuming in appearance, waiting to blossom out under the intense heat of July and August into a wonderful brilliancy and purity of color distinguishable even at long distances. From its thick, 


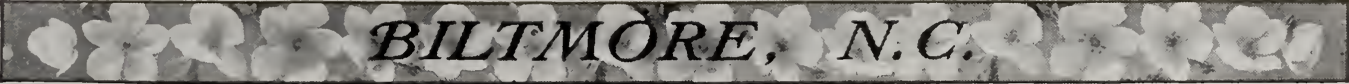

\section{Asclepias tuberosa, continued}

fleshy root, catalogued along with the tubers by some Europeans, several stout, leafy stems grow to a height of 2 or 3 feet, branching near the top and terminating in many corymbs of glowing orange flowers. These are quaintly formed; the narrowly oblong petals are sharply reflexed and above them appendages of almost equal length stand erect in a crown about the center of the flower. As in all Silkweeds, they are followed in autumn by large, hoary pods containing silvery white down. The plants thrive amazingly in any soil that is well drained and sunny, even in sterile spots and near the sea. Landscape gardeners see in it great possibilities, as it can be grown from Michigan to Texas and can be used for brilliant touches of color against belts of shrubbery and groves of evergreens, as well as in the garden. Strong plants, prepaid, 15 cts. each ; larger sizes, purchaser paying transportation, is $\mathrm{cts}$. and 25 cts. each.

\section{Asperula}

Asperula odorata. SweET WOOODRfF. This is the IValdmeister of the Germans, used by them for flavoring their Maitrank, or May wine. Its small, white, 4petaled blossoms are borne in pretty clusters on 6- to 8 -inch stems, above whorls of dark green leaves that have a pleasant odor. The herb is grown as much for the fragrant leaves as for its flowers, which are abundant from May until July. In half-shaded, moist situations it grows luxuriantly until late fall; in dry, sunny ones it soon languishes. Valued for edgings and carpeting shaded places. Strong plants, prepaid, $25 \mathrm{cts}$. each; larger sizes, purchaser paying transportation, 25 cts. and 35 cts. each.

\section{Aster - The Michaelmas Daisies}

Our gardeners, as a rule, have not sufficiently considered the possibilities for garden brightness after frosts, else in American gardens, as well as in English ones, the race of graceful hardy Asters or Starworts, would be given as much attention as the stiffer annual ones. It is a mistake to ignore Hardy Asters for the garden merely because every brookside shows what wonderful effects they are capable

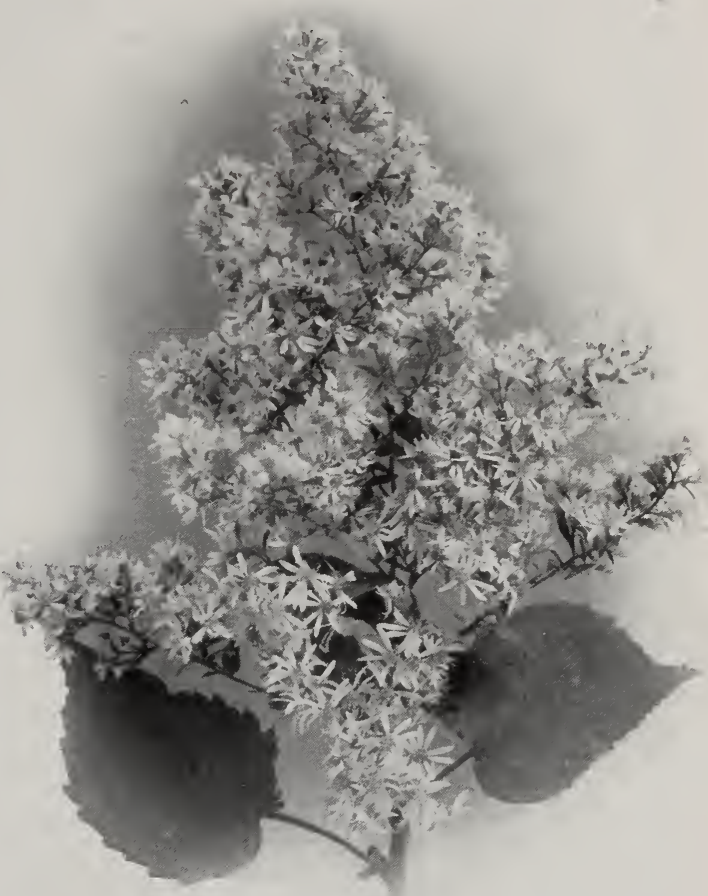

Aster lowrieanus (see page 14)

Aster, continued

of, even in neglect. "The hardy garden really needs the violet of the New England Aster in late summer and autumn, when all else is conspiring in the whole gamut of yellows, and no color is in better harmony

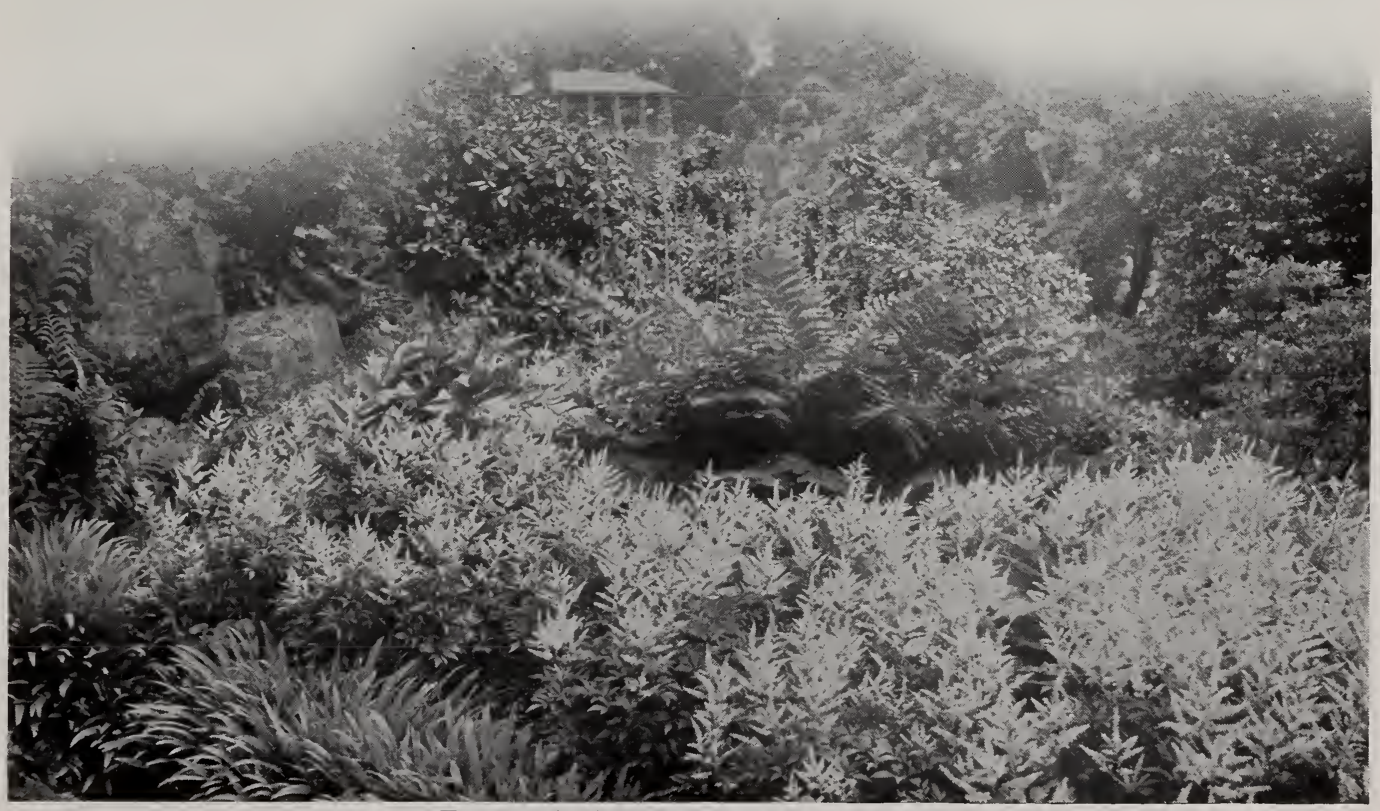

The beautiful and hardy Astilbe japonica (see page 14) 


\section{Q TR BILTMORE' NURSERY WW}

Aster, continued

with the sunshine shades," says a noted landscape gardener. We urge a more plentiful planting of these Asters in the larger beds of the flower garden, among shrubbery and in wild gardens. Usually they are not planted in sufficient quantity to give as grand mass effects as they are capable of producing. The long lineage of the Starworts gives them a greater claim upon gardens of the older type than most flowers. Virgil celebrated them in his Georgics, showing them then to be so much esteemed as to be used for offerings in religious rites; and in 1633 Gerarde sang their praises in his "Great Herball." They are easily cultivated and respond quickly to good care with larger, brighter flowers than those of wildings. A number of the showier forms are described below.

Aster curtisi. Curtis' Aster. A handsome, slender species, indigenous to our North Carolina and Tennessee mountains. The large and showy blossoms are violet-purple, often quite brilliant. Two to 4 feet tall; leaves narrowly lanceolate.

A. lowrieanus. Lowrie's Aster. The sky's own color is reflected in the broad, loose flower panicles of this species, which completely cover stems and leaves, so that a border mass shows only lighter, deeper and silvery tones of blue. Stems clustered, 2 to 3 feet tall.

A. novaeangliae. NEw ENGLAND Aster. This, the richest and gayest of our native Asters, has the largest flowers and is usually conceded to be the finest. Bailey ranks it "among the hest of all hardy border plants." Its stout, leafy stems vary from 3 to y 6 feet in height, according to soil, and
its beautiful violet-pur-
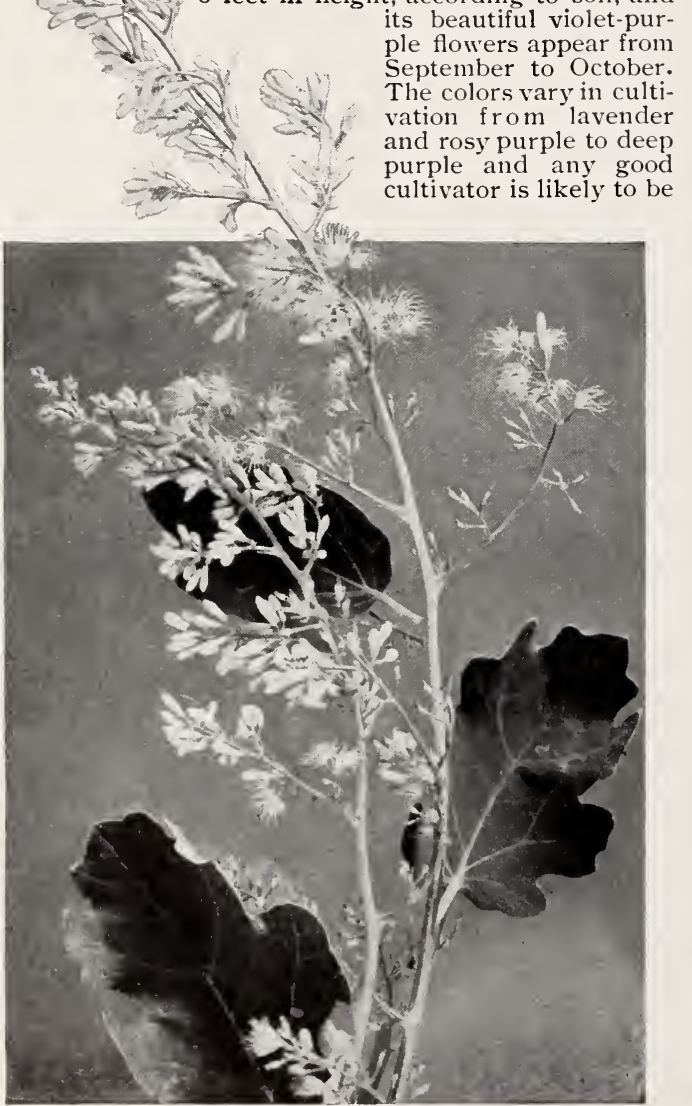

Bocconia cordata (see page 16)

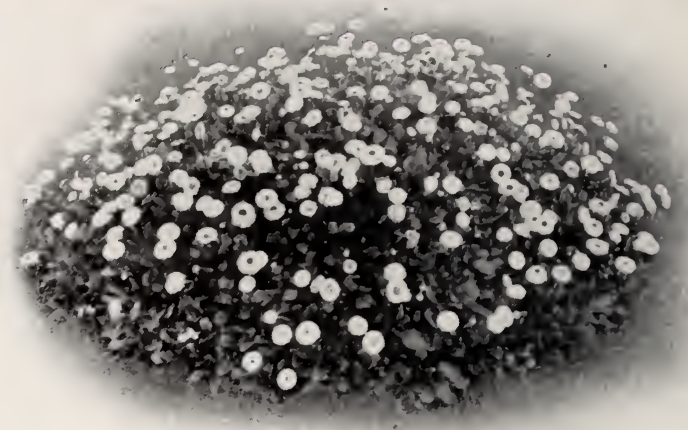

Bellis perennis

Aster novae-angliae, continued

rewarded with sub-varieties that have been honored with special names. A moisture- and sun-loving species, sturdy enough, however, to grow well in any good soil.

A. patens. Late Purple Aster. Flowers deep violet or bluish purple. Very bright and attractive. Two to 3 feet high.

A. puniceus. Purple-stem Aster. A tall and notably beautiful species, much branched near the top and curving with the weight of its lavish bloom until the effect is that of many waves or plumes of violet color, purplish in the shadows, silvery on the crests. Extra robust, spreading rapidly and loving best moist, sunny spots. 3 to 5 feet.

A. undulatus. WVAvy-LeAF Aster. Another species that in its blooming season seems to be composed chiefly of pale violet flower racemes on spreading, bushy stems 2 to 3 feet high. Leaves ovate, or heartshaped. Extra late-flowering.

Any of the Hardy Asters, strong plants, prepaid, 15 cts. each ; larger plants, purchaser paying transportation, 15 cts. and 25 cts. each.

SPECIAL OFFER. A collection of four Hardy Asters, strong plants no two alike, prepaid, 50 cts.; larger sizes, purchaser paying transportation, 50c. and $85 \mathrm{cts}$.

\section{Astilbe}

Astilbe japonica. JAPANESE Astilbe. A perfectly hardy plant, so beautiful and appropriate to Easter forcing that it is given nuch space under glass. It is not difficult to grow in any well-made border and produces as fine plumes of small, pure white flowers outdoors in May if well treated, as it does indoors. Its stems are clustered into dense clumps and the leaves are dark green, displaying the flowers well. Once known as Spirea japonica. Strong plants, prepaid, I5 cts. each; larger plants, purchaser paying transportation, $15 \mathrm{cts}$. and $25 \mathrm{cts}$. each.

\section{Baptisia}

Baptisia australis. Brte INDIgo. This plant has distinction and attractiveness in both leaves and flowers. It forms rounded masses of compound bluish green foliage, and has stems 3 to 4 feet high, terminating in long racemes of pea-shaped indigo-blue flowers in midsummer. Well suited to dry, sterile soils on account of its deep root system and nitrogen-gathering trait. Strong plants, prepaid, $15 \mathrm{cts}$. each; larger sizes, purchaser paying transportation, $15 \mathrm{cts}$. and $25 \mathrm{cts}$. each.

\section{Bellis}

Bellis perennis. ExGlish DAIsy. That a plant so small and dainty as this one should be so hardy is rather astonishing. Sometimes it outstrips all other early plants, opening small pink and white rosettes of 


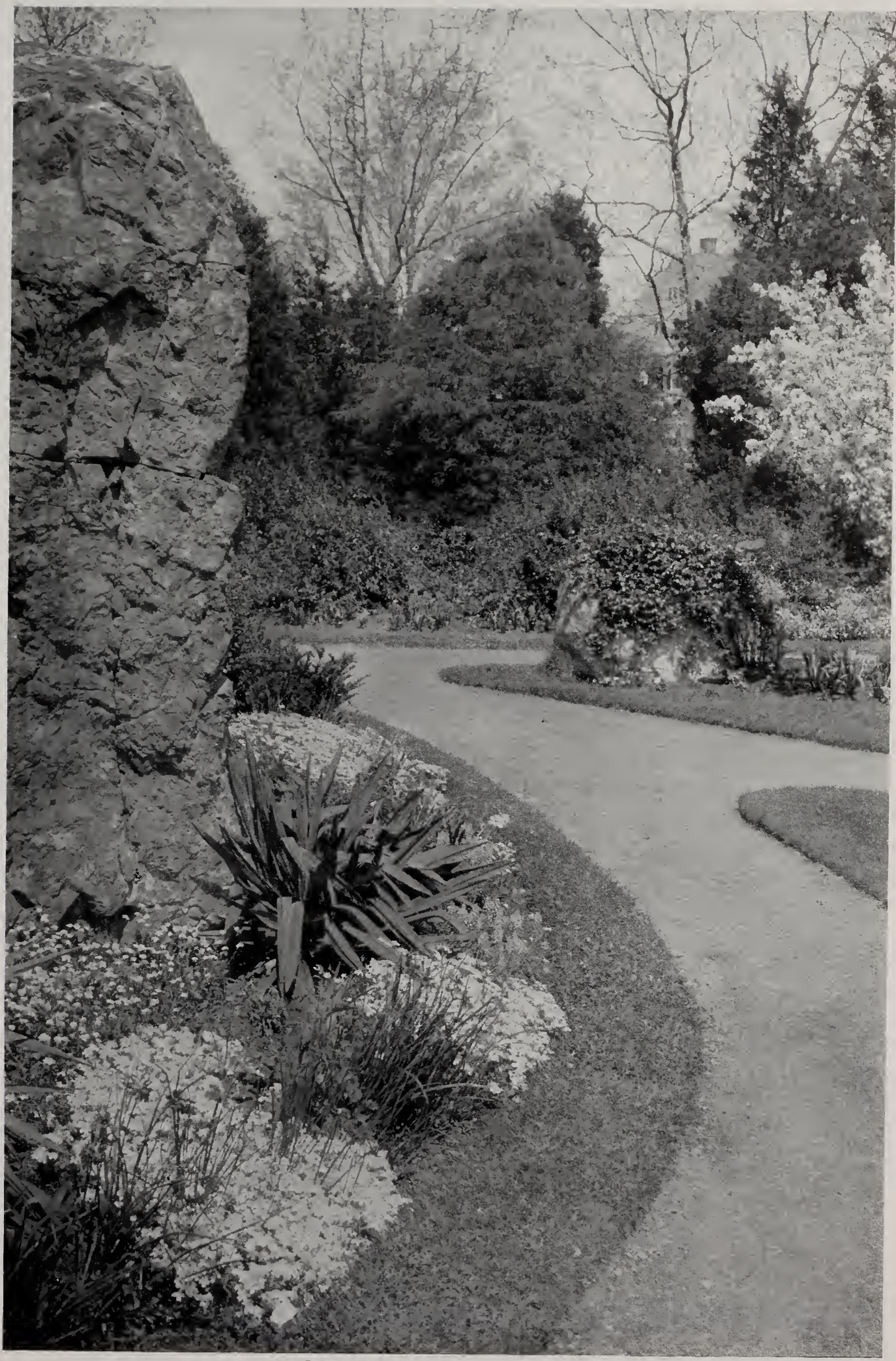

The first spring flowers of a charming garden 


\section{Q RILTMORE NURSERY TWOS}

Bellis perennis, continued

flowers on sturdy 6-inch stems above rosettes of fresl green leaves and keeping up a good succession of them from March through June. Often in cool autumn weather the cheerful rosy blossoms will again appear. English native though it be, we have adopted the Daisy for many uses, and successfully naturalized it in several instances. Children eagerly claim it for their gardens and watch closely for its first spring flowers. It is one of the best edging plants for cool, moist soils, and divides the honors with Pansies and Violets in winter coldframes. Strong plants, prepaid, i5 cts. each; larger sizes, purchaser paying transportation, I5 cts. and $25 \mathrm{cts}$. each.

\section{Bocconia}

Bocconia cordata. Plume Poppy. The Bocconia is worthy of a place in all gardens that can give it room. Few other perennials are at once so bold, handsome and picturesque. Its close-growing stems sometimes reach a height of 9 feet, spreading outward a grand dome of deeply veined, silvery, irregularly lobed leaves, and terminating in great plumes of delicate, misty flowers. These are shaded from ivory-white to reddish brown and remain fresh through many weeks of hottest weather. The nut-brown stems of the withered blossoms should not be cut away, for they will furnish an autumn picture as beautiful as the gradation of tones seen earlier in the flowers. Planted in masses for distant effects about the grounds this tall perennial gives noble pictures, and when seen growing at the back of wide herbaceous borders, associated with such plants as Arundo, Spirea and Delphinium, we forget in admiration the fact that its lusty roots are ramblers. It is a capital plant for the wild garden, where it holds its own with native vegetation. Grown in bottomless tubs or boxes, or where the soil about them need not be disturbed too often, the roots give less trouble. Strong plants, prepaid, I5 cts. each; larger plants, purchaser paying transportation, $15 \mathrm{cts}$. and $25 \mathrm{cts}$. each.

\section{Boltonia - The False Chamomiles}

The Boltonias, like the Asters, open their flowers simultaneously by thousands in late summer and autumn, giving very bright garden pictures. They are more upright in growth than the Asters, with flowers facing upward, require no staking and but a minimum of care.

Boltonia asteroides has pure white flowers on stems 4 to 8 feet high. and spreads into fine masses.

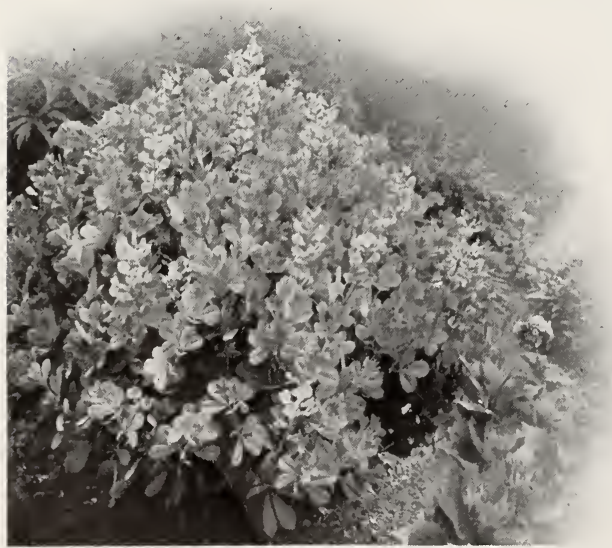

Baptisia australis (see page 14)

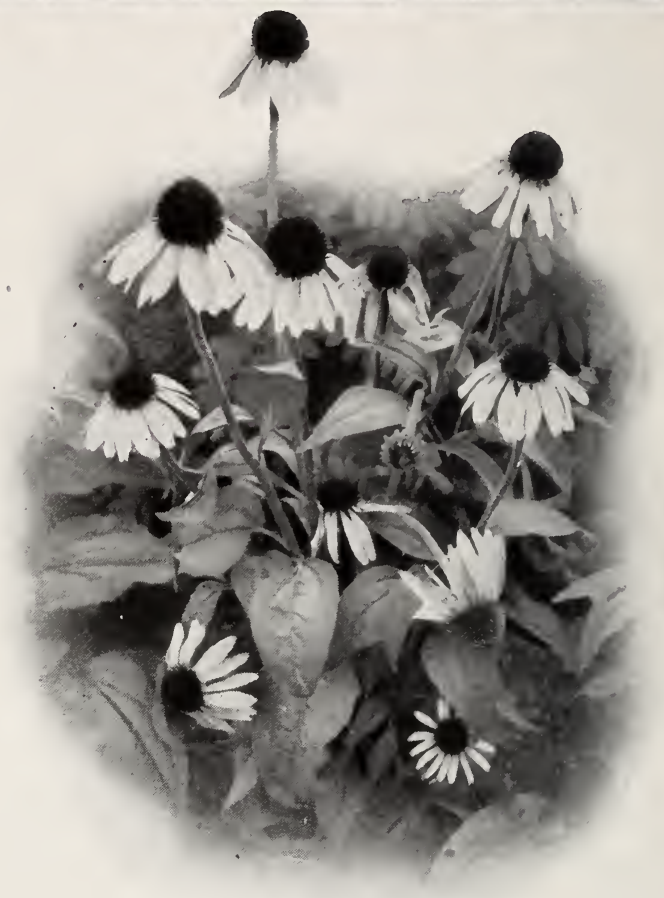

Brauneria purpurea

Boltonia, continued

Boltonia latisquama. This species has larger flowerheads, varying from pink to soft pinkish lavender and blue tints. 4 to 6 feet.

Either of the above, strong plants, prepaid, $15 \mathrm{cts}$. each; larger sizes, purchaser paying transportation, 15 cts. and 25 cts. each.

\section{Brauneria}

Brauneria purpurea (Echinacea purpurea). PURPLE Coneflower. A robust perennial, with large, reddish purple flowers that are most admired in border backgrounds. The common name is suggested by the high central disk of brown which is the apex of the cone formed by the downward-pointing petals. Stout and perhaps a little coarse in appearance, but the 4inch flowers, when seen at a distance, are quite attractive and are abundant for two months or more of late summer. 2 to 3 feet. Strong plants, prepaid, I5 cts. each; larger plants, purchaser paying transportation, I 5 cts. and 25 cts. each.

\section{Callirhoe}

Callirhoe involucrata. POPY MALlow. All through summer this pretty trailing plant produces a good supply of showy, poppy-like flowers varying in color from rosy crimson to cherry-red and rose, with a white central disk. The leaves are deeply 5-to 7-lobed and palmate in appearance. Thrives in sunny situations and in any well-drained soil. Strong plants, prepaid, I5 cts. each: larger sizes, purchaser paying transportation, $15 \mathrm{cts}$. and $25 \mathrm{cts}$. each.

\section{Caltha}

Caltha palustris. MARSH MARIgOLD The brightest yellow flowers of April are the Marsh Marigolds. IV. A. Brotherton urges that the owners of country estates should plant it by tens of thousands in every bit of

Six plants of any one kind will be furnished at five times the single rate, and a dozen plants of any one kind at ten times the price for each plant 


\section{Caltha palustris, continued}

damp woods or marsh that they own, in order to secure broad, shining bands of color in early spring. A few dozen plants scattered along a brookside soon spread into great beds of rich leaves that in spring are almost hidden by riotous yellow blossoms. They will grow well also in ordinary garden beds, but bloon longer in the marshes. One of our best native plants for low grounds. I te 2 feet. Strong plants, prepaid, I5c. each; larger sizes, purchaser paying transportation, $15 \mathrm{cts}$. and $25 \mathrm{cts}$. each.

C. palustris flore pleno. DOUBLE MARSH MARIGOLD. The showy, globe-shaped blooms of this variety have a merry, sturdy air, and look much like over-prosperous Buttercups. Blooms a little later in May, when the luxuriant young foliage is at its finest. Strong plants, prepaid. 25 cts. each ; larger sizes, purchaser paying transportation, $25 \mathrm{cts}$. and $35 \mathrm{cts}$. each.

\section{Campanula - The Bellflowers}

The smaller species of Bellflower, as the Harebell and Bluebell, have a dainty simplicity of beauty that has made them famous. From these range upward a number of taller species, until from the top of the towering Chimney Bellflower might be rung a whole chime of bells. Their beautiful shades of blue make them of great value to gardeners-a value enhanced by their diverse heights and habits. They give us a blue flower for almost every situation, moist or dry, sunny or shaded, and the flowers are produced in summer drought, when their color is needed for cool effects and when fine flowers are always at a premium. Valued also for cut-flowers.

Campanula carpatica. Carpathian HAREBELl. This little blue blossom, to those who know it well, is as precious as the Violet. It is a most charming as well as a most variable species, but in all its forms the flowerstems are loose and graceful and each branchlet terminates with a fine blue or white bell, often an inch or more wide. The plants are compact little tufts of dark green leaves from 6 to 12 inches high and produce flowers abundantly almost throughout the summer.

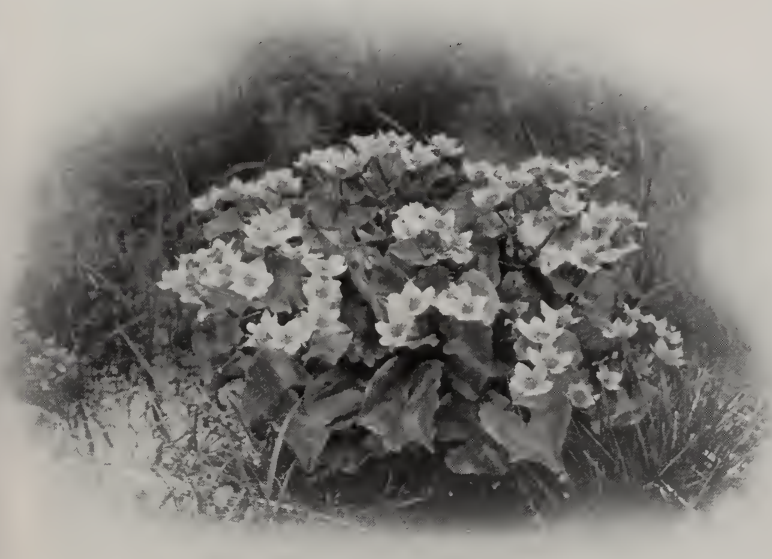

Caltha palustris
Campanula, continued

Campanula medium calycanthema. CANTERBURY BELLS. The quaint old Cup-and-Saucer Campanula, is still one of the best kinds grown. Artistically its great scalloped goblets of various colors are preferable in the single to the double and duplex forms. Below the cup of petals spreads a calyx of the same color into wide saucer shape, its form and size varying in sub-varieties. Besides the superb effect it gives when planted in masses, we find that it is not injured by transplanting when in full bloom to pots for house decoration, where, if the fading flowers are removed, it remains a thing of beauty for several weeks. Only the most symmetrical specimens should be selected for this purpose. The plant is robust, and its several stout stems carry well their showy burden of bloom. The colors vary through deep and light blue to white and pink. 2 to 3 feet.

C. persicifolia. PEACH Bells. One of the most graceful of the taller Bellflowers, its great white or blue cups nodding from the axils of the upper leaves of the clump of branching stems. The popular name is suggested semble those of the Peach. This and the double form below are of especial value for cutting. Height 2 to $3 \mathrm{ft}$.

C. persicifolia alba plena. DOUble Peach BELLS. A superb form of the preceding species, with large double flowers 2 inches or more in width, and having all the waxen regularity of Camellias. Pure white and very showy. Strong plants, prepaid, 25 cts. "each; larger sizes, purchaser paying transportation, 25 cts. and $35 \mathrm{cts}$. each.

C. pyramidalis. Chimney Bellflower. For nearly half their length the tall, tapering stems of this grand species are densely clothed with fine, deep blue, widely opened bells. The leaves are broad and handsome, forming a fine base for the long, branching pyramid of bloom. One of the most beautiful and conspicuous of our late summer flowers. Parisians love to grow it as a pot plant. Height 4 to 5 feet. Strong plants, prepaid, 25 cts. each ; larger sizes, purchaser paying transportation, $25 \mathrm{cts}$. and $35 \mathrm{cts}$. each.

C. rotundifolia. Bluebell of Scotland. From June to August the lovely little flowers hang daintily from slender wiry stems nearly a foot high. Growing in shaded woods, the stems are slenderer and taller than in the garden. The nodding flowers are a clear blue, the leaves almost linear along the stem, broadening at the root,- the whole plant singularly light and lovely in effect. This is the true Harebell or Bluebell which is mentioned so lovingly in Scotch song and story.

Any of the above, unless otherwise noted strong plants prepaid, $15 \mathrm{cts}$. each; larger sizes purchaser paying transportation, 15 cts. and 25 cts. each

SPECIAL OFFER. A collection of four Cam panulas, no two alike, our selection, strong plants, prepaid, 50 cts.; larger sizes, purchaser paying transportation, $50 \mathrm{cts}$. and $85 \mathrm{cts}$.

The perfume of plants is not for the pleasure of the senses merely, but is a rapid and wonderful stimulant to the brain, which receives the subtle essence before any fluid could be absorbed by skin or blood. 


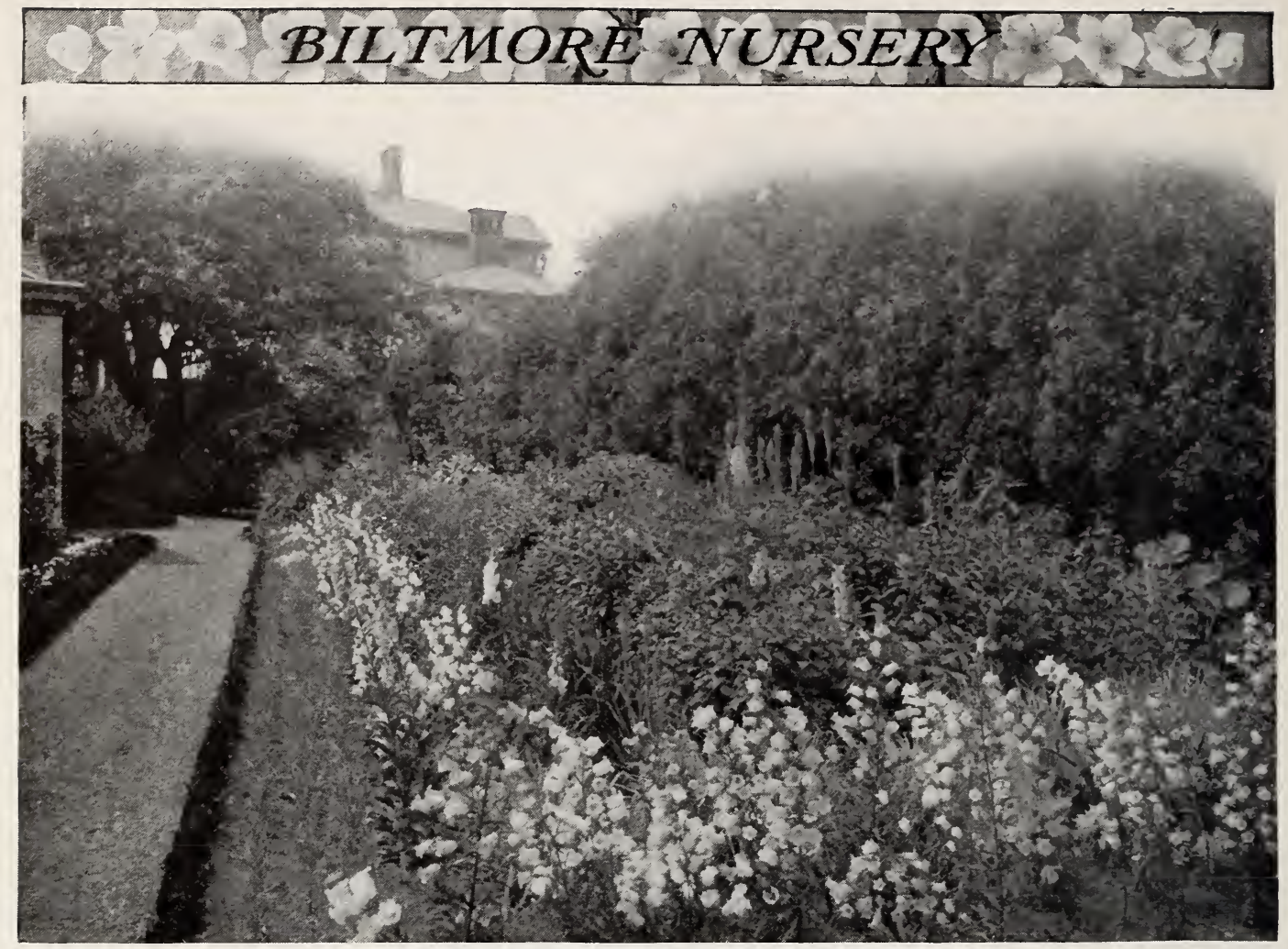

The dainty simplicity of beauty of the Bellflowers (see page 17)

\section{Cassia}

Cassia marilandica. American Senna. A tall, bushy plant with graceful, pinnate leaves resembling those of the Acacia. From their axils in July and August, large panicles of curiously shaped bright yellow flowers are borne abundantly. Sun-loving, and in a sandy soil attaining a height of 3 to 4 feet. A striking plant. Strong plants, prepaid, I5 cts. each ; larger sizes, purchaser paying transportation, I5 cts. and $25 \mathrm{cts}$. each.

\section{Centaurea}

Centaurea montana. Mountain Bluet. Sometimes called Perennial Corn-Flower, from a similarity in the shape and color of its blossoms to those of the real Corn-Flower. The young leaves of the plant are grayish and it forms pretty clumps I to 2 feet high that brighten a sunny border with many picturesque, clear or violet-blue flowers all summer. Strong plants, prepaid, 15 cts. each; larger sizes, purchaser paying transportation, I5 cts. and 25 cts. each.

\section{Cerastium}

Cerastium tomentosum. SNOW-IN-SumMER. An attractive, low and creeping plant, rarely exceeding 4 inches in height except when in bloom. Its downy white leaves, above which a profusion of charming white star-shaped flowers appear in May and June, probably suggested the common name. Much used for edging walks and carpeting beds, where it shines out in pleasing contrast to the grass and the flowers. In dry, sunny places it gives a suggestion of coolness and endures our changeable climate admirably. Strong plants, prepaid, I5 cts. each ; larger sizes, purchaser paying transportation, I5 cts. and $25 \mathrm{cts}$. each.

\section{Ceratostigma}

Ceratostigma plumbaginoides (Plumbago larpenta). LEADWORT. This pretty foreigner was first introduced for greenhouse culture and summer bedding, but proved so hardy that it is now a favorite for rockeries and edgings. Its network of red stems, gleaming here and there through the rich dark leaves, gives support to the many showy clusters of deep blue flowers which appear through late summer and early autumn. One of its chief merits is that it blooms profusely at a time when blue flowers are somewhat scarce among the hardy flowers. In cold climates or exposed situations a winter mulch for this plant is advisable. Strong plants, prepaid, I5 cts. each; larger sizes. purchaser paying transportation, $15 \mathrm{cts}$. and $25 \mathrm{cts}$. each.

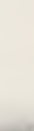

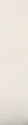

(a)

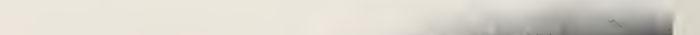




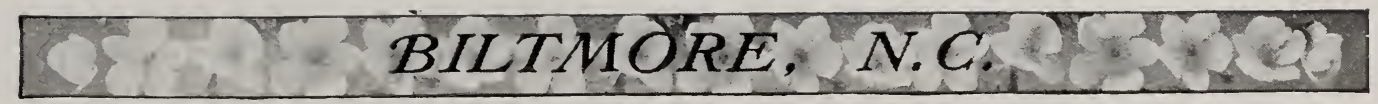

\section{Chelone}

Chelone glabra. Turtlehead. Shlill Flower. This plant has a piquant individuality; despite the fact that casual observers sometimes mistake it for "some kind of a white Closed Gentian." Usually its flowers are waxen white, though occasionally flushed with pink, and densely clustered at the top of stems 2 or 3 feet high. The quaintly formed corolla is 2-lipped, the upper one broad and arching, tne lower somewhat flattened and bearded in the throat; the leaves are lanceolate. Grows well in any good garden soil, but in moist situations is taller, with larger bloom-clusters and flowers. A heavy fertilizing mulch helps to establish the plant in dry soils. Strong plants, prepaid, 25 cts. each; larger sizes, purchaser paying transportation, $25 \mathrm{cts}$. and $35 \mathrm{cts}$. each.

\section{Chrysanthemum}

\section{The Graceful Hardy Pompon Group}

In colonial gardens these were known as Artemisias, perhaps because their bruised leaves exhale an odor similar to that of the true Artemisia, or Wormwood. They are the best autumnal flowers handed down to us from the old-time gardens, and the most resistant to frost and chilling winds. Even after several light falls of snow, in sheltered positions it is sometimes possible to cut uninjured clusters; and for weeks after they fail to pass muster as cutflowers, good mass plantings give life and color to

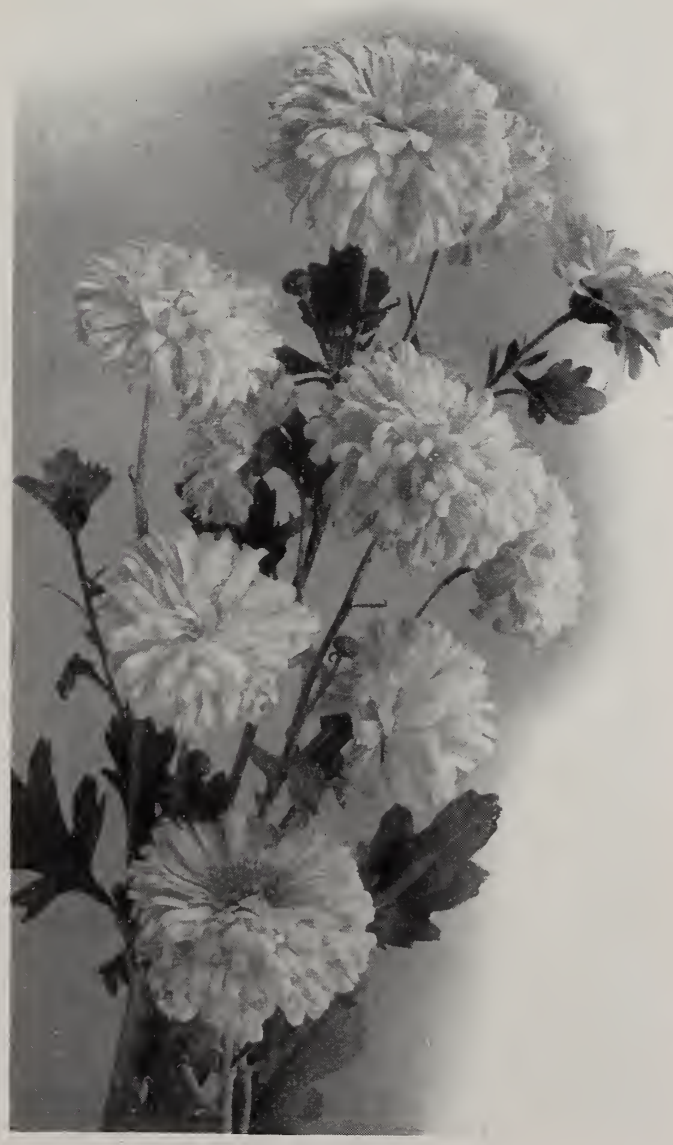

Pompon Chrysanthemums

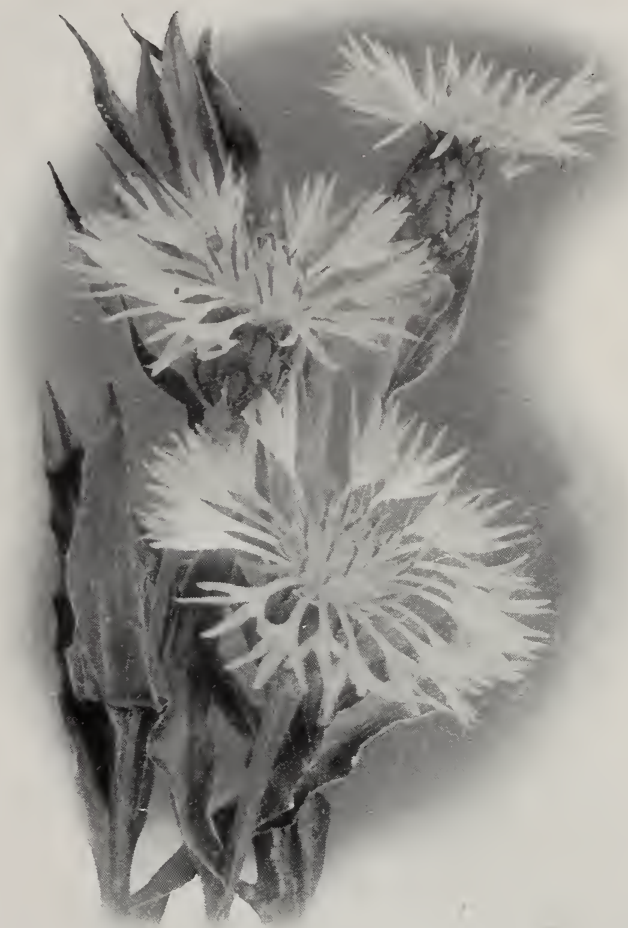

Centaurea montana (see page 18)

Chrysanthemum, continued

the garaen. Nothing else in our outdoor flora can, almost unaided, stave off winter desolation so long. A good border of Hardy Chrysanthemums means a real abundance of late fall flowers, something unknown at Thanksgiving in other ranks. Good taste requires that the vivid colors in early blooming varieties should be grown in colonies or masses by themselves, but the white and the late-flowering ones form good backgrounds for plants of lower stature. Their fine thick foliage makes a good screen or background, and their own blossoms spring into fullest beauty when the earlier flowers are gone. A border of these plants on the south side of wall or hedge remains bright several weeks later than one less happily located. We have selected the following varieties as among the best and showiest in a good range of colors:

Burnet. Rich red.

Danizula. Delicate pink, with dainty touches of rose.

Dundee, Crimson-maroon, lighted with scarlet.

Eagle d'0r. Sunny golden yellow.

Golden Fleece. Light pure yellow.

Golden Pheasant. Brilliant orange.

Julia Lagravere. Garnet-bronze.

President. Violet-red.

Prince of Wales. Pure white, exquisitely formed flowers. Queen of Bulgaria. Bright rosy crimson.

Rhoda. White, flushed with pink.

Veuve Cliquot. Terra-cotta, edged with yellow.

Any of the above Hardy Pompon Chrysanthemums, strong plants, prepaid, 15 cts. each; larger plants, purchaser paying transportation, $15 \mathrm{cts}$. and $25 \mathrm{cts}$. each.

SPECIAL OFFER. A collection of six Hardy Pompon Chrysanthemums, our selection of varieties, no two alike, prepaid, 75 cts.; larger sizes, purchaser paying transportation, 75 cts. and $\$ 1.25$. 


Q. BILTMORE NURSERY I PQ

Chrysanthemum, continued

Chrysanthemum balsamita. COSTMARY A tall, robust plant, grown for the mint-like fragrance of its irregularly oval leaves. The small, flat-topped clusters of flowers resemble those of the Tansy. Strong plants, prepaid, I5 cts. each; larger sizes, purchaser paying transportation, $15 \mathrm{cts}$. and $25 \mathrm{cts}$. each.

Chrysanthemum hybridum. SHASTA DAISY. Startlingly large, semi-double daisies, 3 to 4 inches across and pure white, with petals in two or more rows about a golden center. The plant is extra vigorous and maintains a fine show of great flowers throughout the summer and autumn. Strong plants, prepaid, I 5 cts. each; larger sizes purchaser paying transportation, I5C. and 25 cts. each.
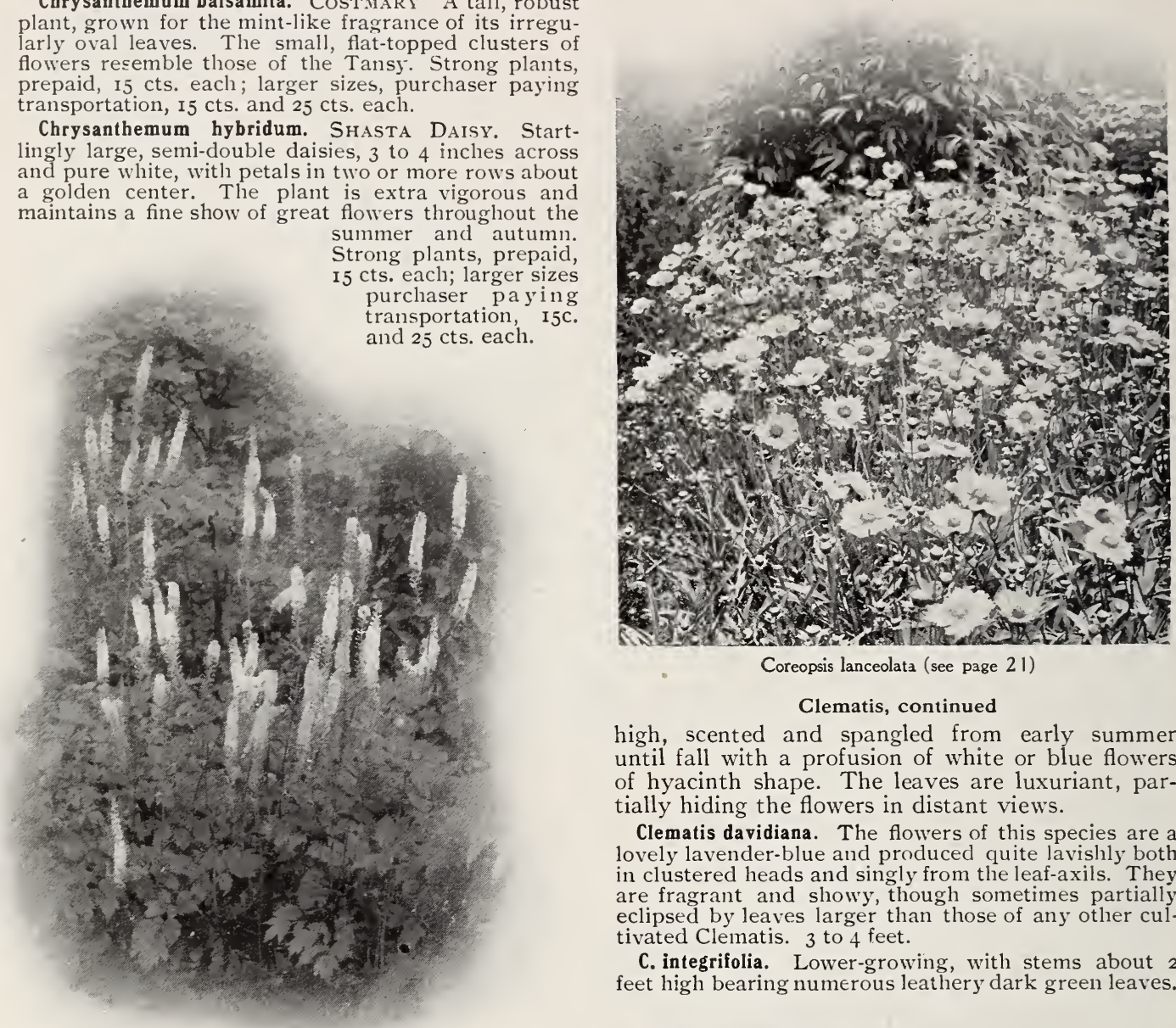

Coreopsis lanceolata (see page 21)

Clematis, continued

high, scented and spangled from early summer until fall with a profusion of white or blue flowers of hyacinth shape. The leaves are luxuriant, partially hiding the flowers in distant views.

Clematis davidiana. The flowers of this species are a lovely lavender-blue and produced quite lavishly both in clustered heads and singly from the leaf-axils. They are fragrant and showy, though sometimes partially eclipsed by leaves larger than those of any other cultivated Clematis. 3 to 4 feet.

C. integrifolia. Lower-growing, with stems about 2 feet high bearing numerous leathery dark green leaves.

Cimicifuga racemosa

\section{Cimicifuga}

Cimicifuga racemosa. Black SNakeroot. An odd, bold, distinct plant, conspicuous at long distances by its tall white rockets of bloom. These are held rigidily erect, to a height of from 4 to 6 feet, the effect being softened by the fluffy whiteness of the blossoms that densely clothe the flower stems. The fruits, which persist quite late, are also ornamental; the decompound leaves are dark and handsome. Strong plants, prepaid, 25 cts. each; larger sizes, purchaser paying transportation, $25 \mathrm{cts}$. and $35 \mathrm{cts}$. each.

\section{Clematis - The Herbaceous Species}

Although some forms of this type of Clematis have been cultivated for three centuries, they are still rare except in gardens of the discerning few. The herbaceous species are as beautiful in their way as the climbing ones, and have proved to be real aristocrats of the border. Single specimen plants also, when well established, in their blooming season are a grand sight. In good soils and sunny exposures they form rounded bushes 3 to 4 feet

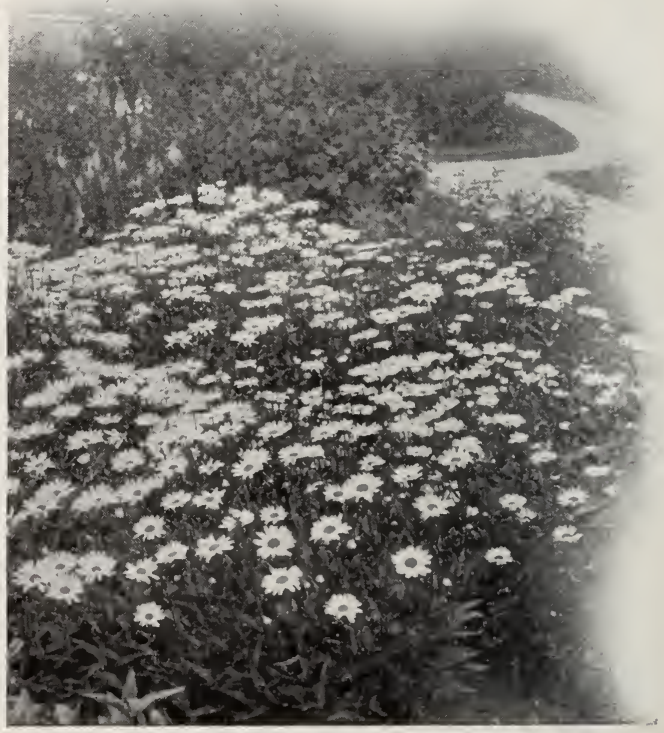

Chrysanthemum hybridum. Shasta Daisy 


\section{Q N BILTMORE, N.C.N NXED}

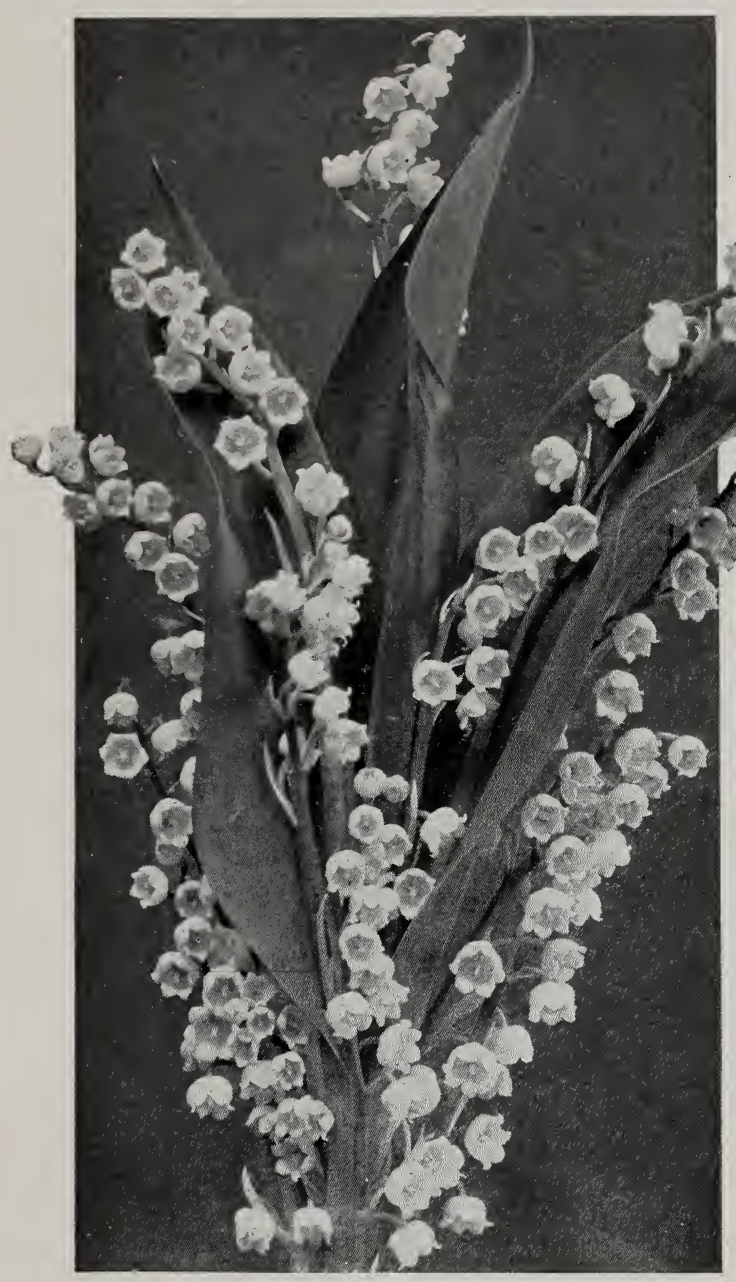

Convallaria majalis

Clematis integrifolia, continued

The flowers are large, from I to 2 inches long, the four recurving sepals dark blue without, lighter within; they are nodding and produced singly from the tips of lateral shoots in great abundance from June to Oct.

C. recta. This plant has dense panicles of fragrant small white flowers similar to those of the rampant climbing Japanese Clematis, $C$. paniculata. The tufted stems are from 2 to 3 feet tall, clothed to the flowers with pretty leaves, and may be had in almost any length their popularity for cutting demands.

Any of the above, strong plants, prepaid, $25 \mathrm{cts}$. each; larger sizes, purchaser paying transportation, $25 \mathrm{cts}$. and $35 \mathrm{cts}$. each.

\section{Convallaria}

Convallaria majalis. LILY-OF-THE-VALLEy. Although it loves rich soil and moist, cool places, it will flourish and cover wide bare spaces in full exposure to the sun, blooming well in early spring. However, in semishaded spots its fragrant nodding white bells are larger, the slender racemes longer, the soft green leaves broader and richer. One of those appealing little flowers that it seems inhuman to mistreat, and, therefore, the colonies of it are usually enriched and replanted every few years. Strong clumps, prepaid, I5 cts. each; larger clumps, purchaser paying transportation, I5 cts. and $25 \mathrm{cts}$. each.

\section{Coreopsis}

For daisy-shaped flowers of various colors, and notably for yellow shades, the Coreopsis is perhaps our best perennial. From June until September some member of the group furnishes an unfailing mass of glowing color for the garden and sheaves of long-stemmed flowers for the decoration of the home. The plants have none of the weedy appearance that mars some of our yellow flowers, yet they grow vigorously in any sunny situation.

Coreopsis lanceolata. LANCE-LEAveD TICKSEED. In this variety the flowers are about 2 inches wide, of a pure golden yellow color. The plant is very showy and remarkable for its freedom of bloum in summer and again in fall. I to 2 feet high.

C. tripteris. TALL Tickseed. Produces numerous large, bright yellow flowers on leafy stems 4 to 6 feet high.

C. rosea. Pink Tickseed. A pretty, creeping, slender-branched herb, with daisies pink instead of yellow, and an inch or less across, blossoming freely through several weeks of summer. The stems are from I to $\mathrm{I}^{\mathrm{T}} / 2$ feet high and clothed densely with narrow lea ves. A good plant for rock gardens.

Any of the above, strong plants, prepaid, $15 \mathrm{cts}$. each ; larger sizes, purchaser paying transportation, 15 cts. and 250 each.

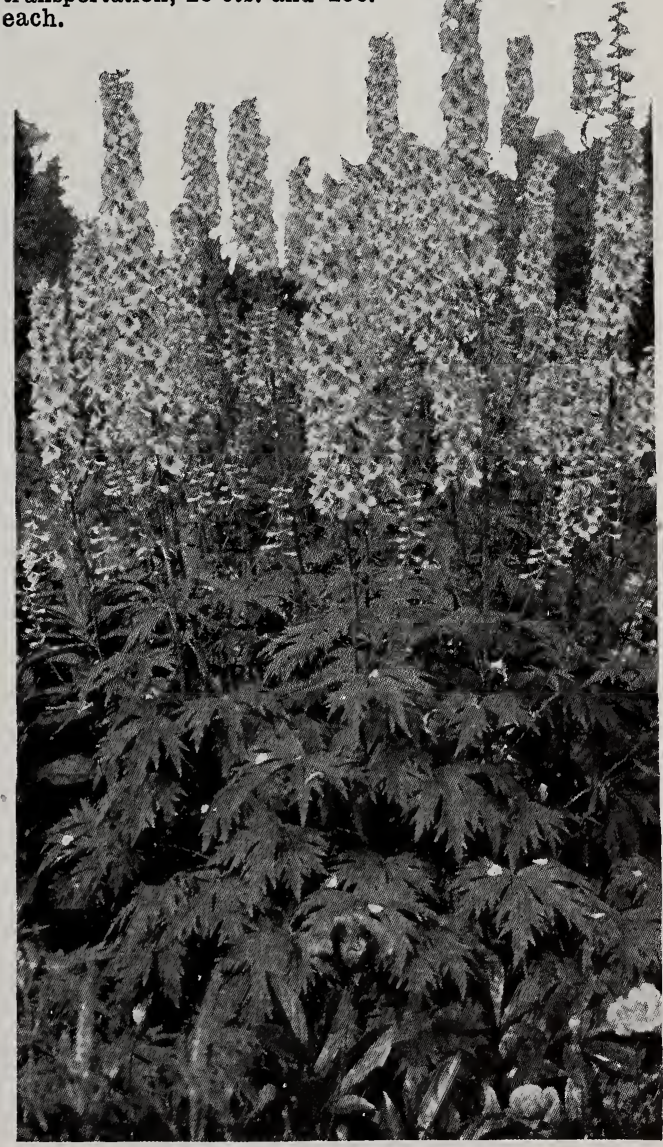

Delphinium formosum (see page 23) 


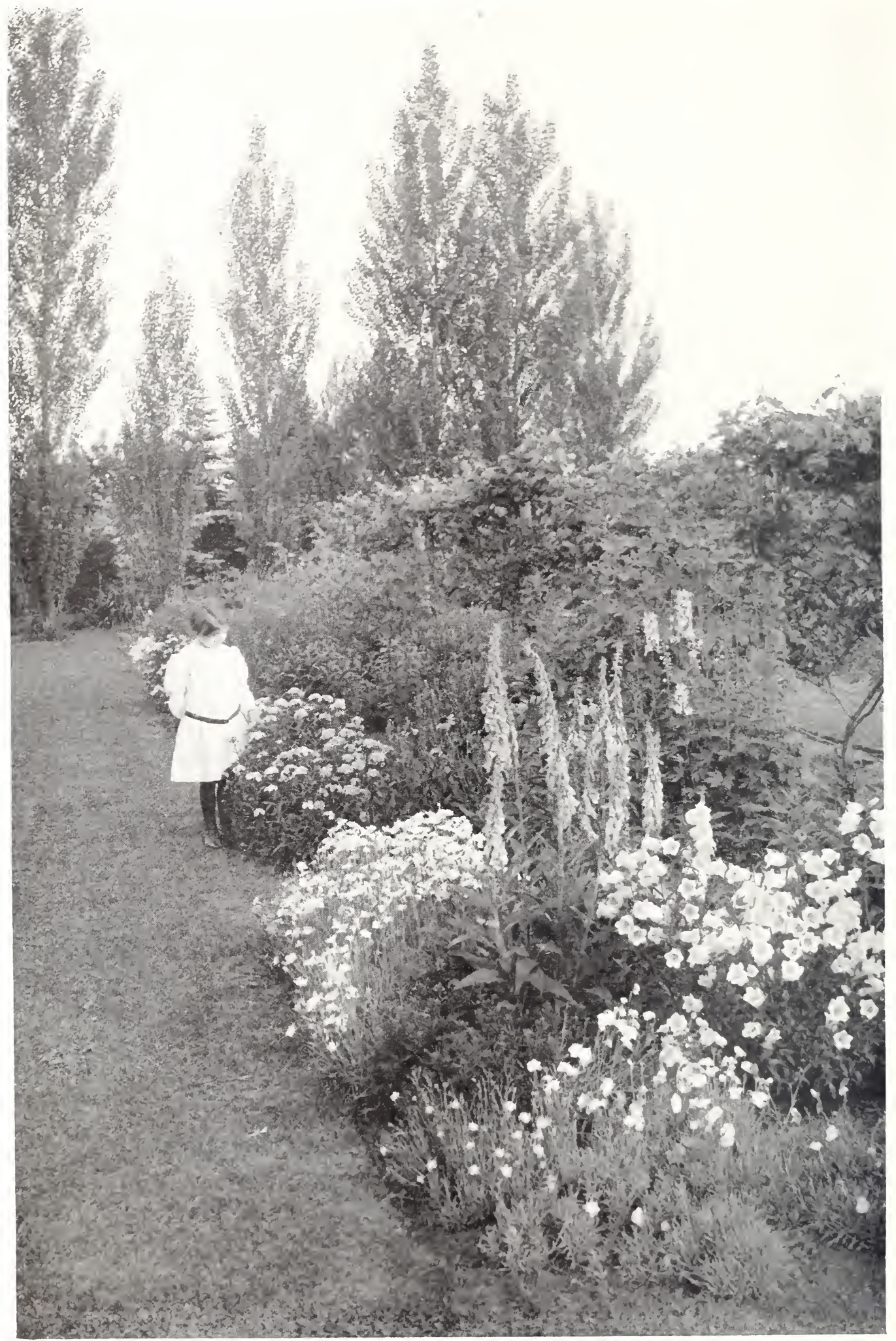

The beauty of the hardy garden is ever varying and ever appealing 


\section{Coronilla}

Coronilla varia. CRows Vetch. This vigorous, showy creeper spreads rapidly, making thick mounds of growth from $I$ to 2 feet high. The flowers are peashaped and borne in dense umbels from June until September, their bravest show occurring usually in July. The long, odd-pinnate leaves are rich, dark green. One of the best plants for covering waste places and rough, dry banks. Strong plants, prepaid, I5 cts. each; larger sizes, ptirchaser paying transportation, 15 cts. and $25 \mathrm{cts}$. each.

\section{Corydalis}

Corydalis nobilis. FunITORY. An odd and interesting perennial of neat habit, the delicately cut leaves suggesting those of the Bleeding Heart. The longspurred flowers of white and yellow are borne on stems a foot high in early spring. Native of Siberia. Hardy and permanent in growth. Strong plants, prepaid, 25 cts. each; larger sizes, purchaser paying transportation, 25 cts. and $35 \mathrm{cts}$. each.

\section{Delphinium - The Larkspurs}

One of the finest sights of modern gardens is a good collection of blooming Larkspurs. They give us the greatest abundance of flowers and the utmost variety in tints and shades of blue. Ellwanger says that Keats should have included them in his sonnet on blue. For the greater part of July the Larkspur is queen of the hardy border, and then you may see the rare color from palest sky tints to deepest hues of amethyst and violet, silvered and bronzed and velvet-dappled, in light-poised flowers of fanciful shape. Some of the bloom-stems will cluster in light loops at your feet; other tall spikes challenge your admiration face to face. Now the colors wane toward white; a further glance may startle you with stems of vivid red. England has made the Larkspur an exhibition flower, and hybrids with bloom-stems 3 feet high and blossoms $2 \frac{1}{2}$ inches across are not unusual there. Will this fine old perennial thus be over-developed and hybridized until good taste rebels and we are glad to return to the older normal sorts?

If the July flower-stems are cut away as soon as they fade, a second series of lighter ones will follow, and thus a succession of bloom be kept up until frost. Tall species make good border backgrounds, but all sorts are seen at their very best when grown in masses or large groups of separate colors. Although the plants thrive in any good garden soil, a deep, rich loamy one, with sunny exposure, is best suited to their needs. The species described below are among the best.

Delphinium cashmerianum. HimALAYAN LARKSPUR. An especially attractive dwarf species, from I2 to 18 inches high. The large flowers are about 2 inches long and so intensely blue that the upper petals seem almost black. The leaves are clustered about the root; the flower-stems abundant in summer.

D. formosum. SHOWY LARKSPUR. In the bloom of this species the blue tints are so shaded and disposed as to give unusually brilliant effects. The lighter center deepens to a blue-black margin; the spurs are violet. The stout stems are from 2 to 3 feet high and clothed
Delphinium formosum, continued

with fine delicately cut leaves. One of the most permanent older forms that blooms persistently through summer and responds readily to cutting back with spikes of fine autumn blossoms.

D. grandiflorum. CHINESE LARksPUR. A fine and sturdy old type, fascinating because of its many variations as well as for its beauty. In their blooming season a large bed of Chinese Larkspurs keeps their owner hovering about daily to see what new colors or freaks the flowers will display next. The leaves are finely cut and fern-like, the clustered stems branching, 2 or 3 feet high, the flowers single or double with long, tapering spurs and colors ranging from clear deep blue through various shades to creamy white. For about Io weeks of midsummer it makes a grand display of bloom. Young plants often show good flowers until smothered with snow.

D. nudicaule. CALIFORNIA LARKSPUR. This species is dwarf and compact-growing, with branching stems I 2 to 18 inches tall from a good cluster of root-leaves. The large outer segments of the flowers are orangered, the small inner ones yellow; they are disposed in graceful panicles that show distinctly each vivid blossom, and appear in early summer.

Any of the Larkspurs, strong plants, prepaid, 25 cts. each; larger sizes, purchaser paying transportation, 25 cts. and 35 cts. each.

SPECIAL OFFER. A collection of three Larkspurs, no two alike, our selection of varieties, strong plants, prepaid, 60 cts.; larger sizes, purchaser paying transportation, $60 \mathrm{cts}$. and $85 \mathrm{cts}$.

\section{Dianthus Pinks and Sweet Williams}

The sweet and spicy old Clove, Grass and May Pinks, together with Sweet Williams, are too lovely to be relegated entirely to old-time gardens. In his "Century Book of Gardening" Mr. E. T. Cook says that they are our most popular edging plants; and though we have many plants admirable for edgings, the statement may pass unchallenged. The more simple and unpretentious forms that cover the ground with close mats of silvery foliage, beautiful even in winter, and fill the air in spring with the clove scent of their myriads of blossoms, are generally used for this purpose. Gayest of all are the Chinese Pinks and Sweet Williams. For merry eyes and jocund effects they vie with the Auriculas, while their petals are almost as brilliant and much

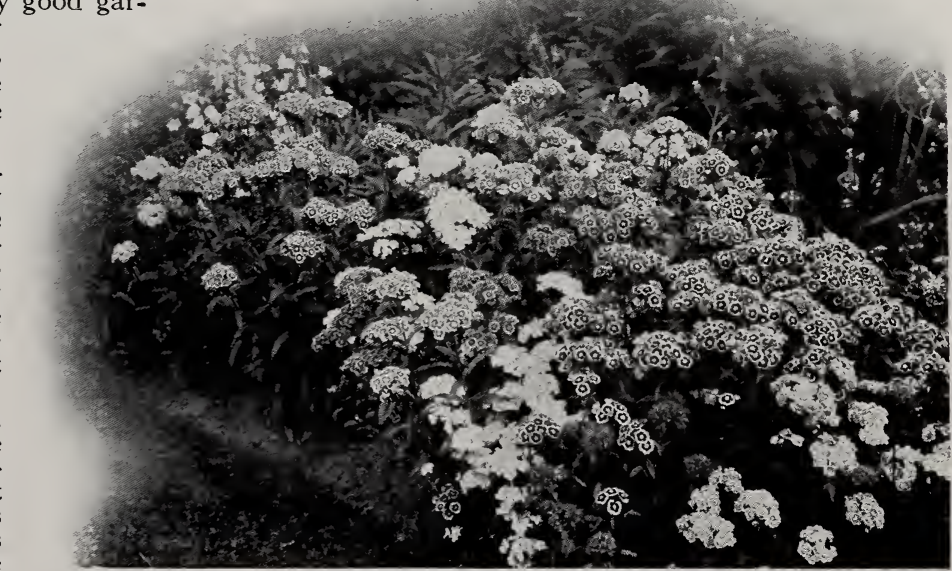

Dianthus barbatus (see page 24) 


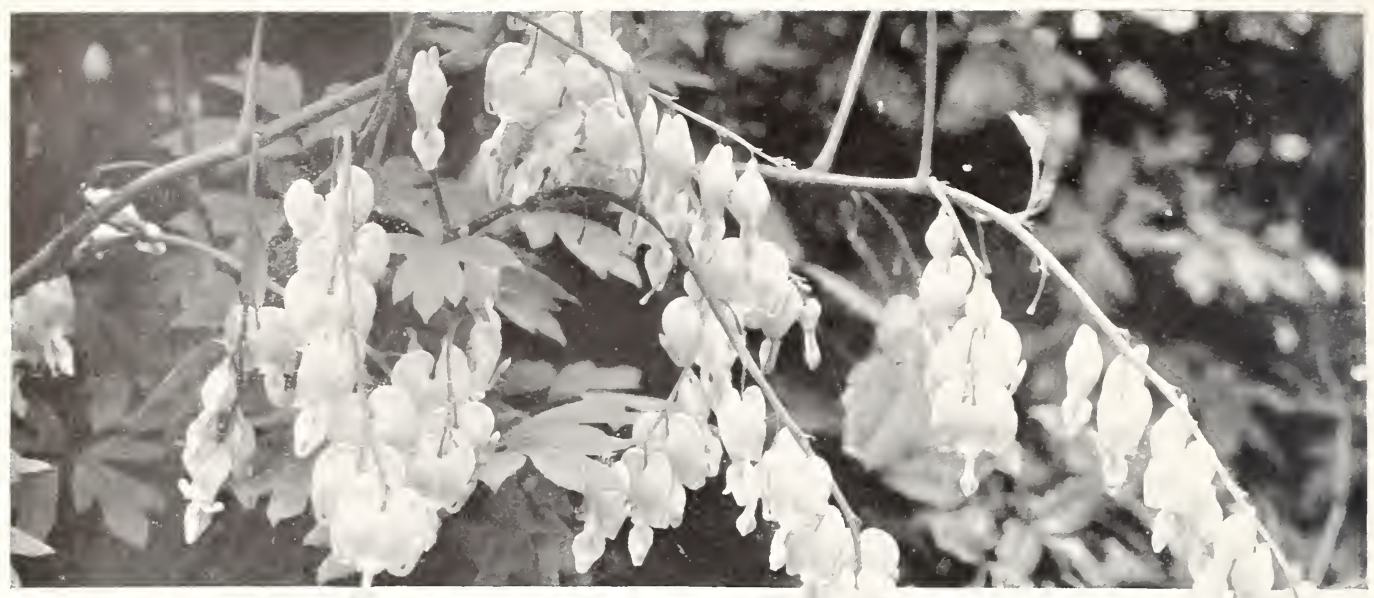

Dianthus, continued

more enduring than those of Poppies. Although they endure neglect and hard conditions, the plants quickly show their appreciation of warm soils and sunny exposures.

Dianthus barbatus. SweET Williar. The Sweet IVilliam gives to flowery May masses of color as brilliant as any of our perennials. The lavish flowertrusses are sometimes 4 inches across and fragrant, with all their florets daintily formed. For 5 weeks or more their splendor lasts, then, if the fading flowers are persistently cut away, fairly good fresh ones appear at intervals all summer. We offer both doubleand single-flowered forms in a orand mixture of varying shades, from white, through pink, to deep, dark red.

D. chinensis. Chivese or INDIAN PINk. This brilliant race has large flowers elegantly fringed and bordered in colors of rich red, crimson, maroon, clear pink, lilac, white, etc.

D. deltoides. MAIDEN PINK. One of the prettiest border pinks, forming neat mats of foliage starred with

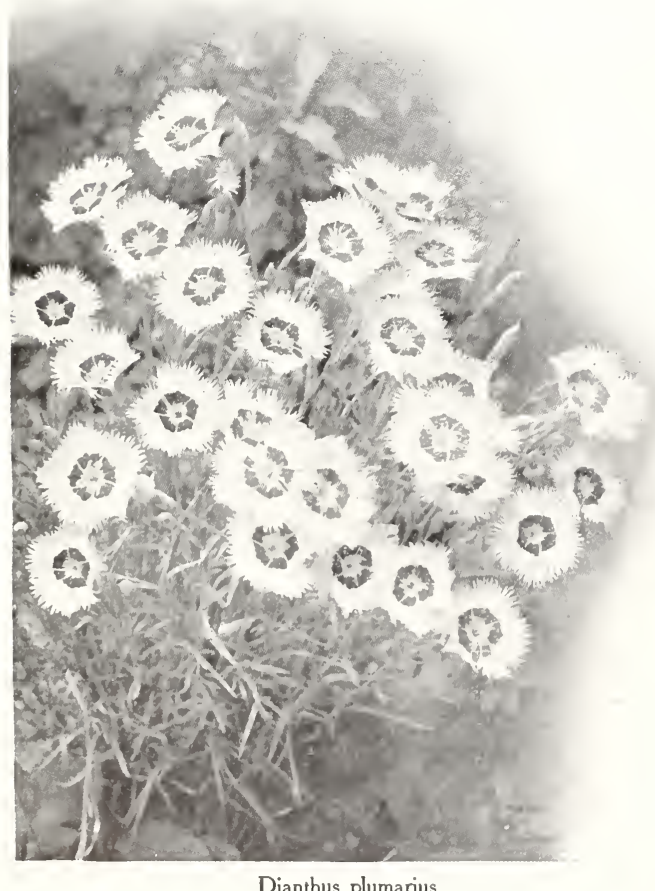

$$
-4-6 y
$$

Dianthus deltoides, continued a multitude of bright little flowers, deep red, with a crimson eye, in spring and early summer.

D. latifolius. Everblooning Sweet IVIllian. Very free-blooming, producing its large and very double blossoms in dense clusters on 6-to 12 -inch stems for the greater part of the growing season. Very showy, as their color is a fiery crimson.

D. plumarius. Scotch Pink. Grass Pink. PheasANT'S EYE PINK. The low, charming species so much used in old gardens for edging beds, bordering walks and naturalizing in great irregular patches. For rockeries, too, there is nothing finer. From its dense mat of silvery blue foliage spring myriads of tufted stems about a foot high, swaying with every breeze their fragrant, fringed, white, pink, or lilac blossoms. Single and double.

Any of the above, strong plants, prepaid, $15 \mathrm{cts}$. each; larger plants, purchaser paying transportation, $15 \mathrm{cts}$. and 25 cts. each.

SPECIAL OFFER. A collection of three Dianthus, no two alike, our selection of varieties, strong plants. prepaid, 35 cts.; larger sizes, purchaser paying transportation, $35 \mathrm{cts}$. and $60 \mathrm{cts}$.

\section{Dicentra - The Bleeding Hearts}

Bleeding Heart, the popular name of the Dicentras, is from the curious heart-shaped blossoms, with the drop of blood below, as seen in Dicentra spectabilis. These perennials were great favorites in the old gardens, and formed magnificent old clumps there. They are very hardy and permanent and bloom quite early in spring.

Dicentra eximia. Alleghany Bleeding Heart. Although a native and an unusually attractive plant, this is comparatively new to gardens. Its curving sprays of pink flowers appear from spring through summer, but are most abundant in May, when they give a solid mass of color if planted in large groups or ivide borders. The fresh, light green, delicately cut leaves are used like Ferns for bouquets.

D. formosa. Californian Bleeding Heart. Similar to the preceding, but has pale rose-colored flowers. Both are exquisite plants for the wild garden or for Rhododendron beds, but also grow well in open sun.

D. spectabilis. BleEding HeART. The taller oldtime favorite, with clustered stems i to 2 feet higlt, abundant deeply cut leaves of glaucous green and many long, curving sprays of deep rose flowers. It blooms very early in spring.

Any of the above, strong plants, prepaid, $15 \mathrm{cts}$. each; larger sizes, purchaser paying transportation, $15 \mathrm{cts}$. and $25 \mathrm{cts}$. each. 


\section{Dictamnus}

Dictamnus fraxinella. Gas Plant. FraxiNELLA. A tall, fine and remarkably vigorous old-time perennial that will flourish for decades undisturbed on the same spot. It forms dense clumps of pretty pinnate leaves on stems about 3 feet tall, crowned by showy terminal racemes of larkspur-like flowers in June. Both leaves and blossoms have a spicy citrus odor. The popular name is from the trautition of a volatile oil emitted by its flowers which caught flame from a lighted match.

D. fraxinella alba. Similar to the above, but with larger flowers of purest white in long racemes.

Either of the above, strong plants, prepaid, 15 cts. each; larger sizes, purchaser paying transportation, 15 cts. and $25 \mathrm{cts}$. each.

\section{Digitalis}

Digitalis purpurea. FoxGLOVE. "It is impossible to resist the spirit of the Foxglove," says Prof. F. A. VVaugh. "Its whole expression is one of aspiration. Every one who has the rudiments of an imagination thinks at once of churcl towers and bells. Although the foliage is somewhat heavy, the whole plant is one of the stateliest of perennials, having the same sort of formal beauty as the Larkspur, which a little later reigns in the same border." It is this dignified formal beauty which makes the Foxglove so desir-

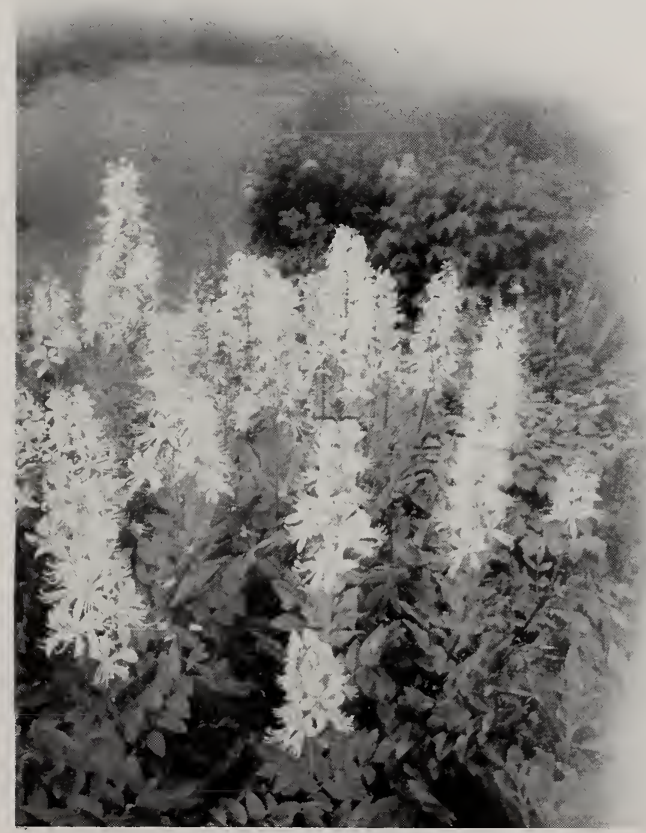

Dictamnus fraxinella alba

\section{Digitalis purpurea, continued}

able for planting near buildings, to repeat in its stately spikes their vertical lines; for backgrounds and contrast among shrubbery, also, it is a very fine plant. Above the soft, heavy leaves the great bloom-stems rise grandly sometimes for 5 feet, and the upper half of the stem is densely set with the tubular flowers of white, rose or purple, which are often curiously spotted in the throat. Although so tall, the stems require no staking, and remain perfect for weeks; they are succeeded by lighter lateral spikes if the first ones are cut away early. A capital plant for naturalizing. Strong plants, prepaid, I5 cts. each; larger plants, purchaser paying transportation, i 5 cts. and $25 \mathrm{cts}$. each.

\section{Dode- catheon}

Dodecatheon meadia. SHOOTING STAR . AMERICAN Cowslip. A particularly pretty and odd little plant with curious, cyclamen - shaped blossoms in an umbel at the top of a slender scape. The petals are pink or white, spotted with orange at the base, and recurve

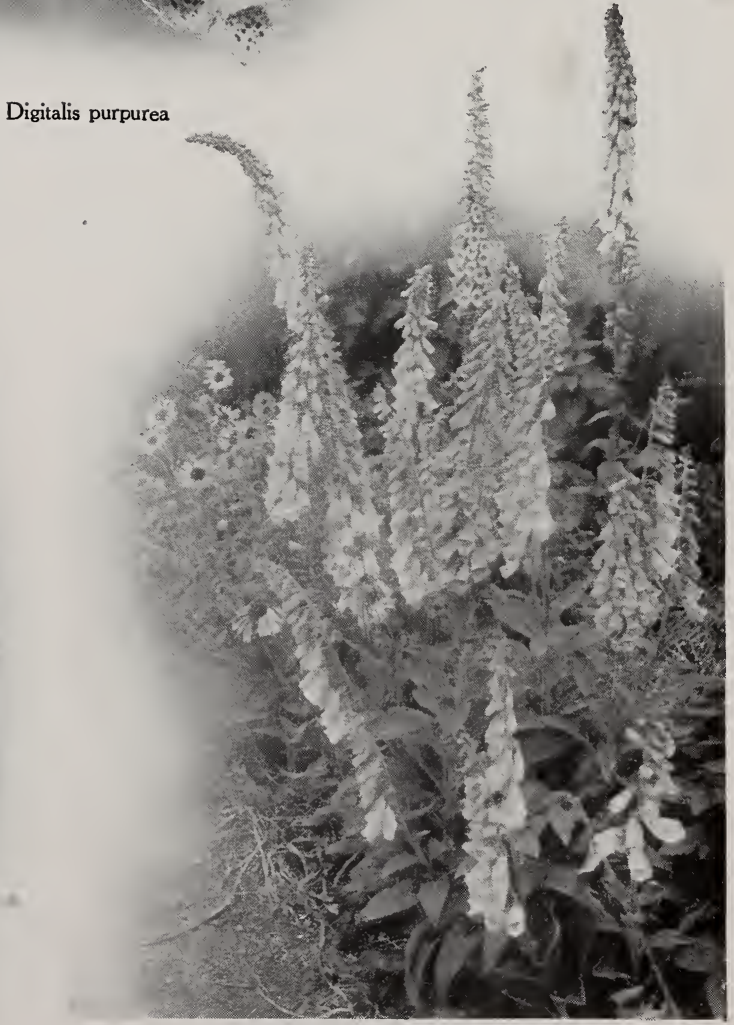

Digitalis, the stateliest of perennials 


\section{Q. BILTMORE NURSERY WIP}

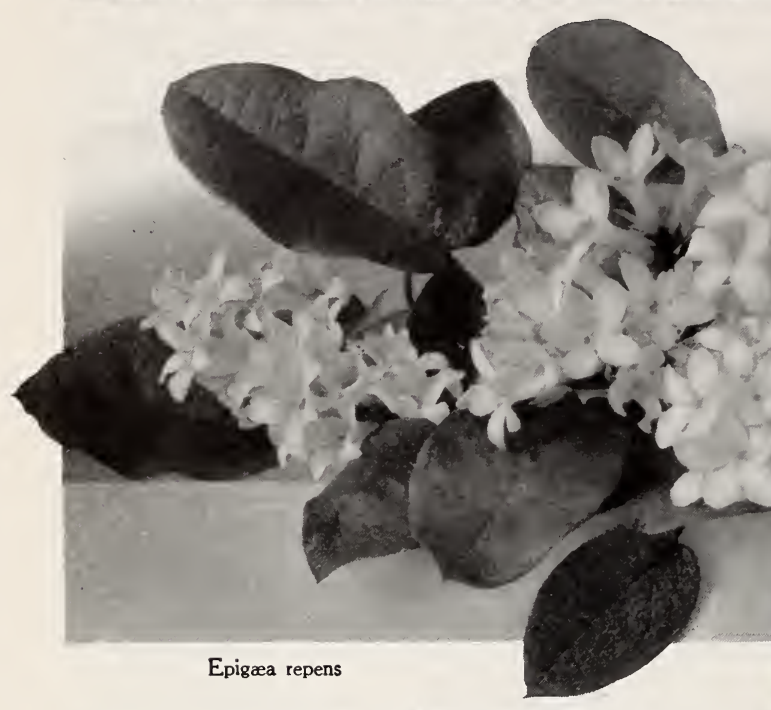

Dodecatheon meadia, continued sharply backward from the center. The bright green leaves are clustered at the root; the flowers open in spring. Somewhat rare in gardens, though easily grown. Strong plants, prepaid, I5 cts. each; larger sizes, purchaser paying transportation, $15 \mathrm{cts}$. and 25 cts. each.

\section{Doronicum}

Doronicum caucasicum. LEOPARD's BANE. The Doronicum is always welcome for the abundance of bright yellow daisies that it gives in early spring while such flowers are yet at a premium. They are 2 or 3 inches wide and can be cut with fine stems. The plant is of distinct, clean growth and has no weedy appearance. Those who have never tried potting the roots in fall to force like Daffodils in the window-garden or greenhouse have an interesting experiment yet in store. Single garden clumps give little idea of the beauty of which this perennial is capable when grown en masse. Easily grown, as sunny in its April effects as the Daffodil, and quite lasting in house decoration. Strong plants, prepaid, 25 cts. each; larger sizes, purchaser paying transportation, $25 \mathrm{cts}$. and $35 \mathrm{cts}$.

\section{Epigaea - Trailing Arbutus}

Epigaea repens. MAYFLOWER. The dainty Arbutus is sought for more eagerly in the wild than any other blossom. Its rough evergreen leaves guard and shelter carefully the delicate pink or white clusters of flowers. Often their fragrance is the first intimation that the shy beauties are hidden near-by. The brown stems of the little creeping vine are hard and woody, but they send roots downward every few inches, so that a thick mat of leaves several feet wide is formed in a few years. In transplanting Arbutus remember its native habitac, the rich, well-drained woods earth of shaded slopes; carefully place the compact ball of roots at their accustomed depth and dare to hope for surcess. Strong clumps, prepaid, 25 cts. each larger sizes, purchaser paying transportation, $25 \mathrm{cts}$. and 35 cts. each.

\section{Epimedium}

The Barrenworts are an exceptionally interesting group of perennials not yet given general culture in hardy gardens. The structure of the flowers is as intricate and fascinating as that of the Orchids, and in foliage and habits they

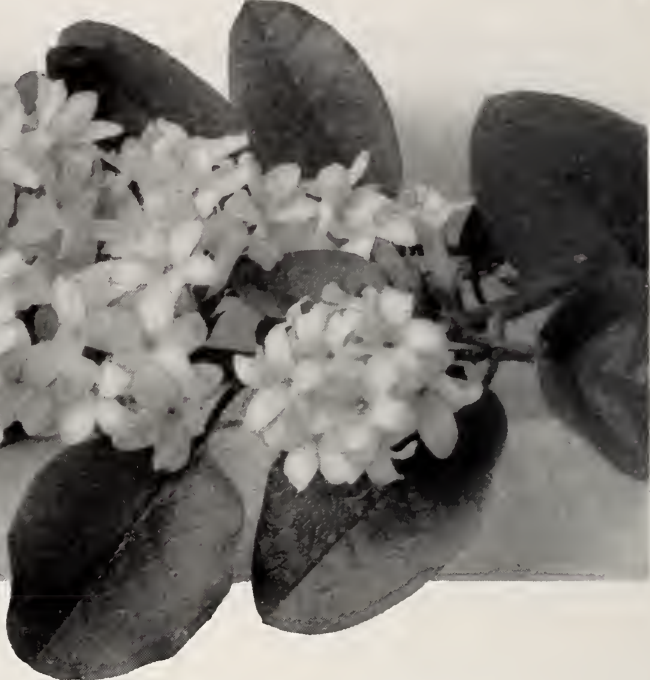

Epimedium, continued

have an odd, foreign air. The flowers have eight sepals and four petals, usually recurved and assuming fantastic shapes; the leaves are pinnately subdivided, deeply veined and serrate; the stems a foot or two high. The young leaves have bronzy tints and are sometimes used for decoration like those of the Galax; in sheltered spots they are persistent through winter, and brightly colored. Easily grown and particularly well suited to rockeries, and for low borders.

Epimedium coccineum. SCARLET BARRENWORT. Curious bright red flowers.

E. lilacea. LiLAC BARRENWORT. Especially odd and interesting; has long lilac spurs.

Either of the above, strong plants prepaid, 25 cts. each; larger sizes, purchaser paying transportation, 25 cts. and 35 cts. each.

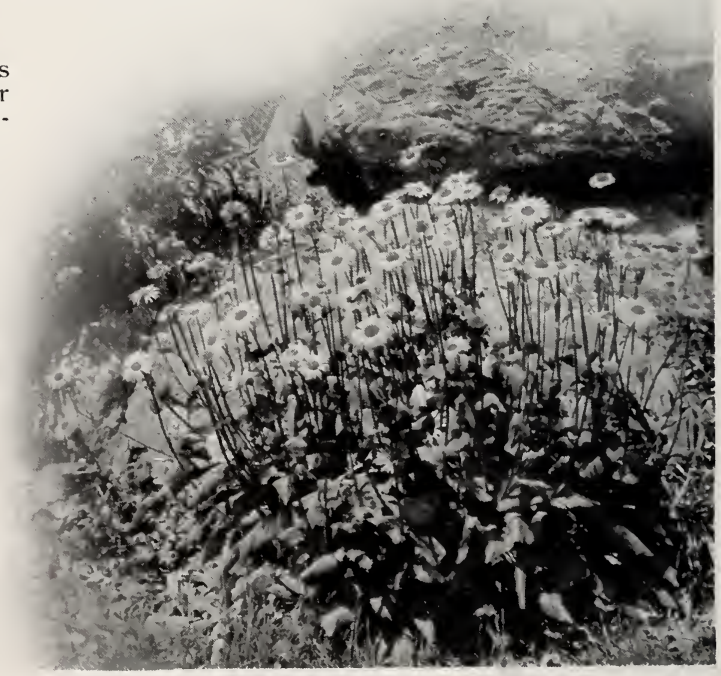

Doronicum caucasicum 

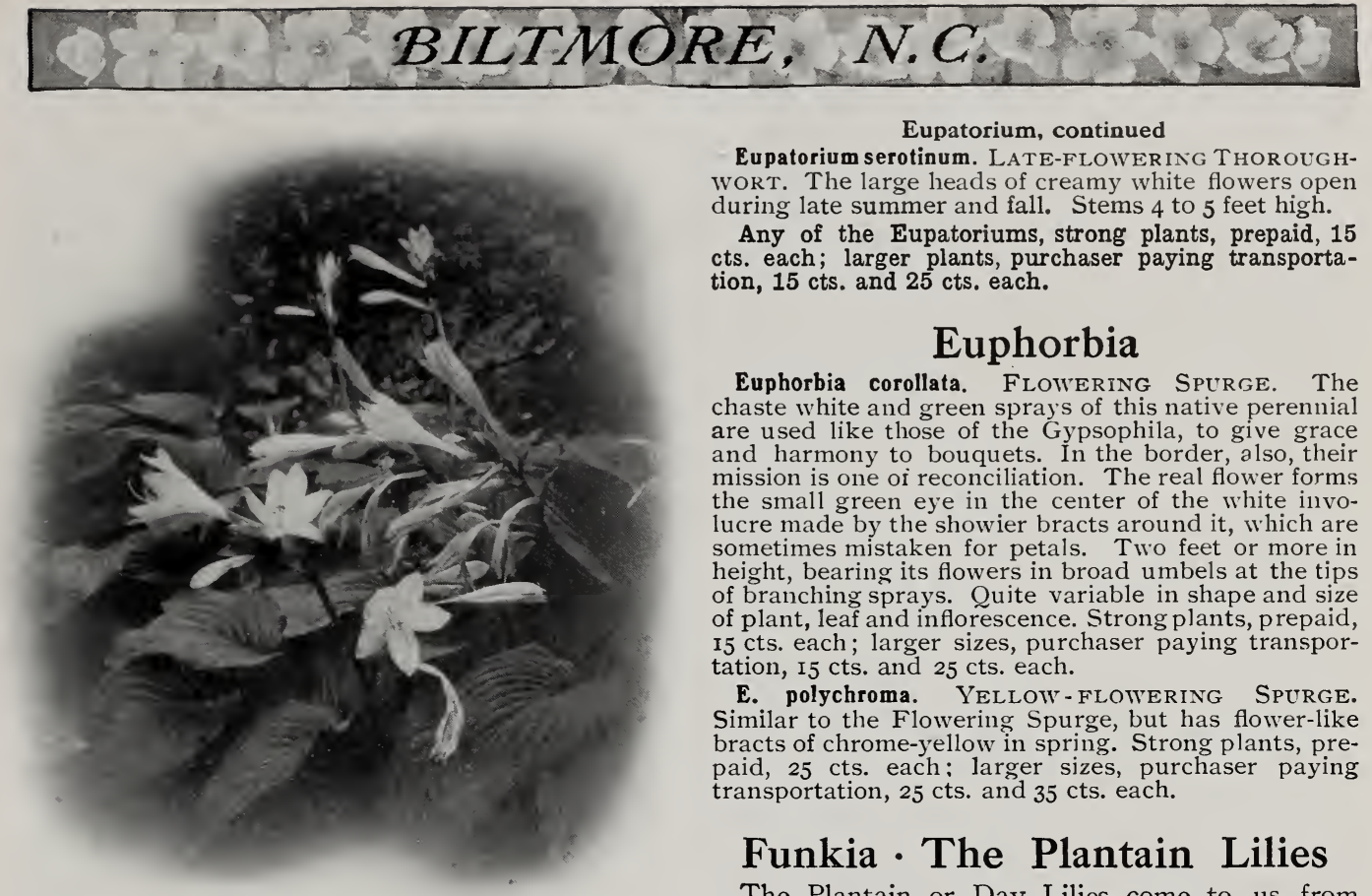

Eupatorium, continued

Eupatorium serotinum. LATE-FLOWERING THOROUGHWORT. The large heads of creamy white flowers open during late summer and fall. Stems 4 to 5 feet high.

Any of the Eupatoriums, strong plants, prepaid, 15 cts. each; larger plants, purchaser paying transportation, 15 cts. and 25 cts. each.

\section{Euphorbia}

Euphorbia corollata. Flowering SPURGE. The chaste white and green spray's of this native perennial are used like those of the Gypsophila, to give grace and harmony to bouquets. In the border, also, their mission is one of reconciliation. The real flower forms the small green eye in the center of the white involucre made by the showier bracts around it, which are sometimes mistaken for petals. Two feet or more in height, bearing its flowers in broad umbels at the tips of branching sprays. Quite variable in shape and size of plant, leaf and inflorescence. Strong plants, prepaid, I5 cts. each ; larger sizes, purchaser paying transportation, I5 cts. and $25 \mathrm{cts}$. each.

E. polychroma. Yellow-FLOWERING SPURGE. Similar to the Flowering Spurge, but has flower-like bracts of chrome-yellow in spring. Strong plants, prepaid, 25 cts. each: larger sizes, purchaser paying transportation, $25 \mathrm{cts}$. and $35 \mathrm{cts}$. each.

\section{Funkia - The Plantain Lilies}

The Plantain or Day Lilies come to us from

Funkia subcordata (see page 28)

\section{Erigeron}

Erigeron glauca. Fleabane. A bright-flowered, lowgrowing plant similar to the English Daisy in habit, seen at its best when grown in masses in border or wild garden. The rosy violet blossoms are borne singly on stems 9 to 15 inches high and are suitable for cutting; the leaves form a close rosette above the root and are silvery hoary. Akin to the "Spring Daisies" and the Robin's Plantain. Strong plants, prepaid, I5 cts. each; larger sizes, purchaser paying transportation, I5 $_{5} \mathrm{cts}$. and $25 \mathrm{cts}$. each.

\section{Eupatorium}

This showy and picturesque family of plants is earning for itself the recognition it deserves in landscape gardening. We have few plants better for naturalizing along brooksides or for grouping among shrubs and as border backgrounds. The Eupatoriums will grow literally anywhere, but love full sun and moist places best. The small, individual flower-heads of all the species are aggregated into broad showy masses.

Eupatorium ageratoides. IVhite SNAKeroot. An attractive, shade-loving border plant, with small loosely graceful heads of white blossoms massed in wide, irregular corymbs on stems 3 to 4 feet high in August and September.

E. coelestinum. HARDY AgERAtum. So lavish of bloom that a good border mass of it forms a solid flake of color, exquisitely blue, in August and September. I8 to 24 inches.

E. purpureum. Joe Pye IVEed. No plant of our waning summer is more boldly conspicuous and handsome than Joe Pye, wrongly, as we maintain, called a weed. Given the right landscape uses it makes noble pictures, with its long, whorled leaves, 8 -foot stems and great, rounded flower-heads. The specific name, also, is misleading, for the small flowers of the huge, fluffy cluster are lavender-pink, instead of purple, with lighter instead of darker shades. A good plant for bold grouping, for distant effects and for waterside planting.

Japan and are among the most honored of our older garden plants. Their glossy, parallel-veined leaves all spring from the root and many flower-stems rise from the center of a good clump. The flowers are white, blue or lilac, in terminal racemes or spikes. Although each one lasts for only a day, new flowerstems are sent up continuously through August and

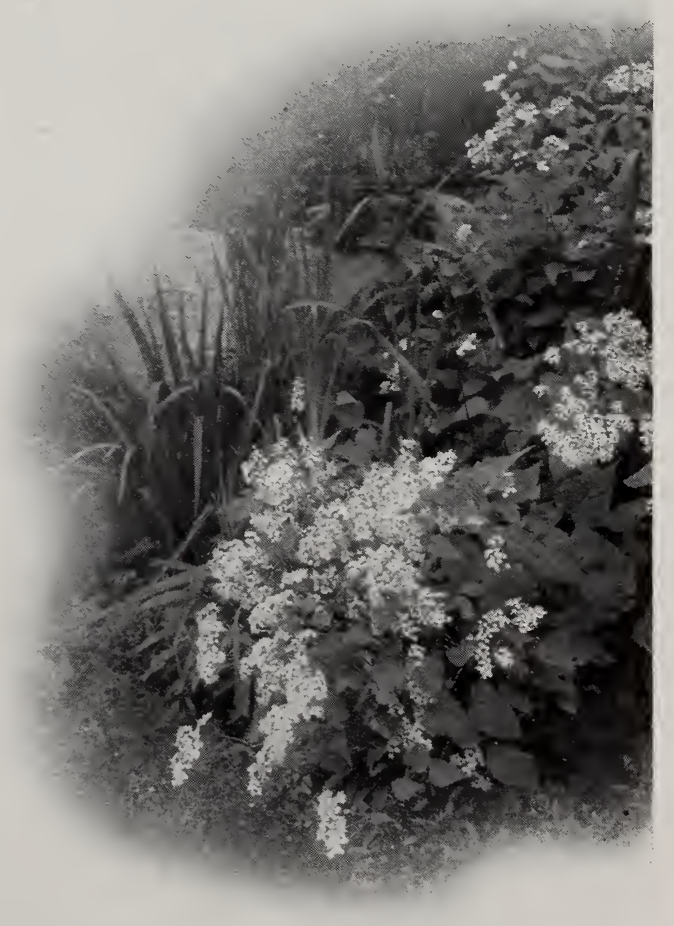

Eupatorium ageratoides 


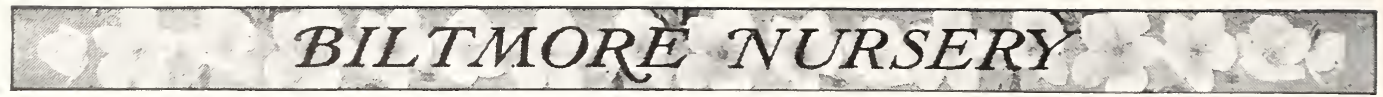

Funkia, continued

the flowers are abundant all through that month. In rich, deep, semi-shaded soil the clumps improve with age. Good plants for the angles of buildings and for defining walks or drives.

Funkia lancifolia. NARROW-LEAyed DAy Lily. From the center of a good clump of this species spring many wand-like stems a foot or two high strung with from 6 to Io little nodding pale lilac lilies. The shining, lanceolate leaves form a thick cluster about the root.

F. ovata. BROAD-LEAVED DAY LILY. This species has broader leaves and larger flowers of a deeper blue. More showy and less dainty.

F. subcordata. White DAy Lily. A superb old perennial of much bolder growth. forming luxuriant clumps several feet in width. The leaves are broad, heart-shaped, glossy and deeply veined-almost as handsome as the flowers, which are from 4 to 6 inches long, pure white, and scent the garden at evening with a delightful orange-like odor.

Any of the Funkias, strong plants, prepaid, 15 cts. each; larger sizes, purchaser paying transportation, 15 cts. and $25 \mathrm{cts}$. each.

SPECIAL OFFER. One each of the above, strong plants, prepaid, 35 cts.; larger sizes, purchaser paying transportation, $35 \mathrm{cts}$. and $60 \mathrm{cts}$.

\section{Gaillardia}

Gaillardia grandiflora. BLANKET Flower. The Gaillardias are glorious for rich and barbaric colors in the many rings and eyes of their blossoms. Glorious, too, for the wonderful way in which they keep these colors all a-glitter in thousands of flowers from early summer until frost. Far from quenching their brilliant shades of orange, yellow, brown and red, a long drought merely emphasizes the value of Gaillardias, by showing their indifference to it, while other plants hang drooping heads. This large-flowered variety is the best in the perennial species. Its flowers have centers of dark red-brown; its petals are marked with rings of rich crimson, orange and vermilion. The plant grows about 2 feet and thrives in any sunny, well drained spot. Strong plants, prepaid, I5 cts. each ; larger sizes, purchaser paying transportation, $15 \mathrm{cts}$. and $25 \mathrm{c}$. each.

\section{Galax}

Galax aphylla. Galax. Colt's Foot. One of the most beautiful evergreen herbs, so beautiful, in fact, as to threaten its extinction in the wild, for its glossy, brilliant leaves are gathered and shipped in carloads for house decoration. These leaves are round-cordate, with crimped edges and sprightly undulations, and stand in shining groups several yards wide where good colonies of two or three years have been established.

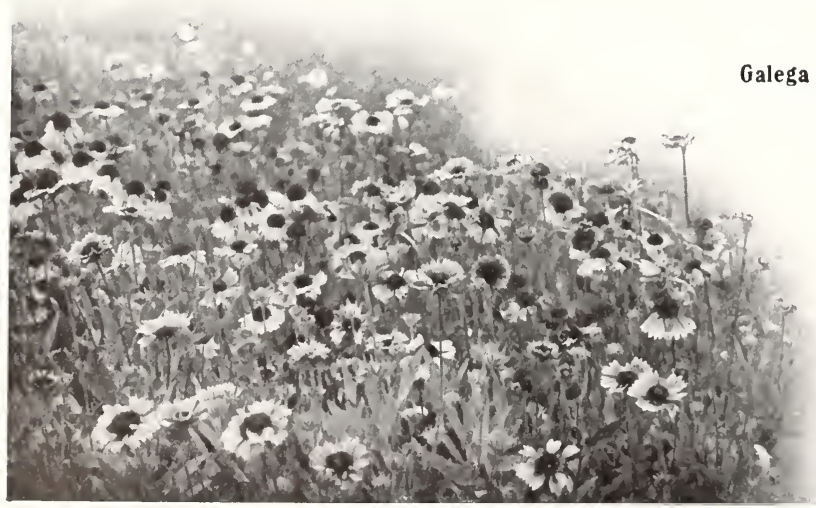

Gaillardia grandiflora

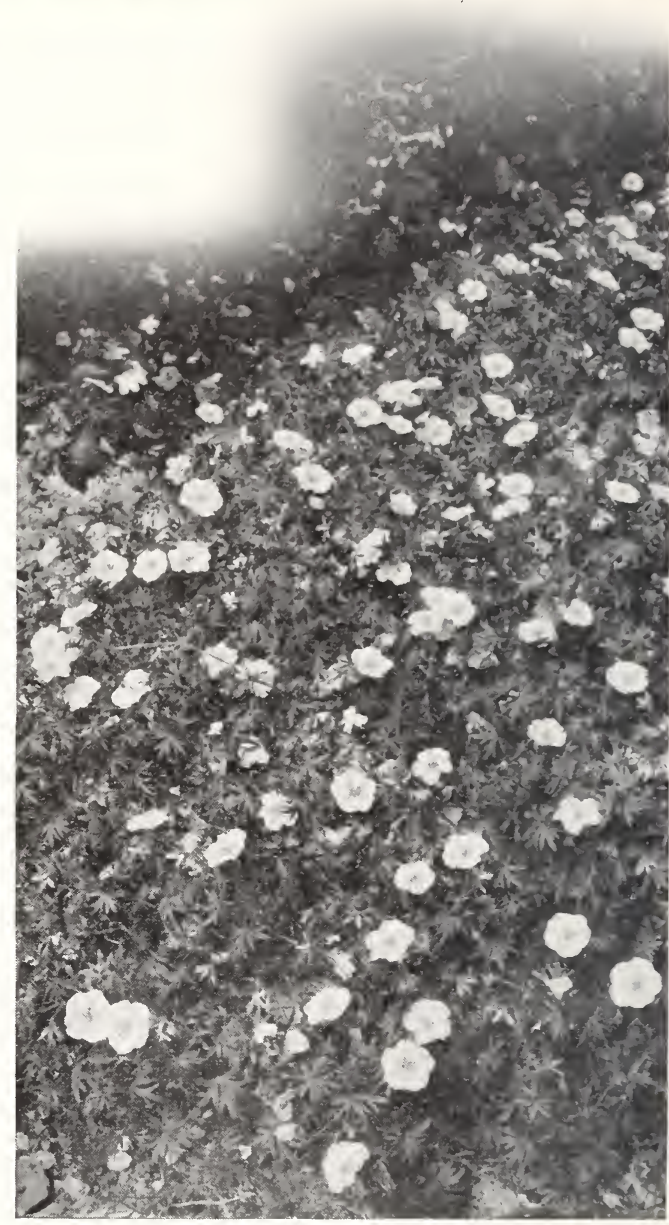

Geranium sanguineum (see page 30 )

Galax aphylla, continued

In exposed places they color brilliantly to bronze and red in fall. Slender scapes of white flowers appear among them in April. The Galax forms a capital ground cover for beds of Kalmias and Rhododendrons, and is quite hardy as far north as Boston. Strong clumps, prepaid, 25 cts. each; larger sizes, purchaser paying transportation, $25 \mathrm{cts}$. and $35 \mathrm{cts}$. each.

\section{Galega}

alega officinalis. GoAT's RuE. In Juiy and August the Galega bears many dense axillary and terminial clusters of fine purplish blue peashaped flowers that are useful for cutting. They form bushy plants about 3 feet high, have graceful, pinnate leaves and are easy to grow in almost any situation. Strong plants, prepaid, I5 cts. each; larger sizes, purchaser paying transportation, I5 cts. and 25 cts. each.

\section{Galium}

Galium verum. Bedstraw. Always attractive and interesting on account of its odd formation. The stems are 4angled and elongated; the long, narrow leaves are arranged in regular whorls. The flowers are yellow, disposed in 


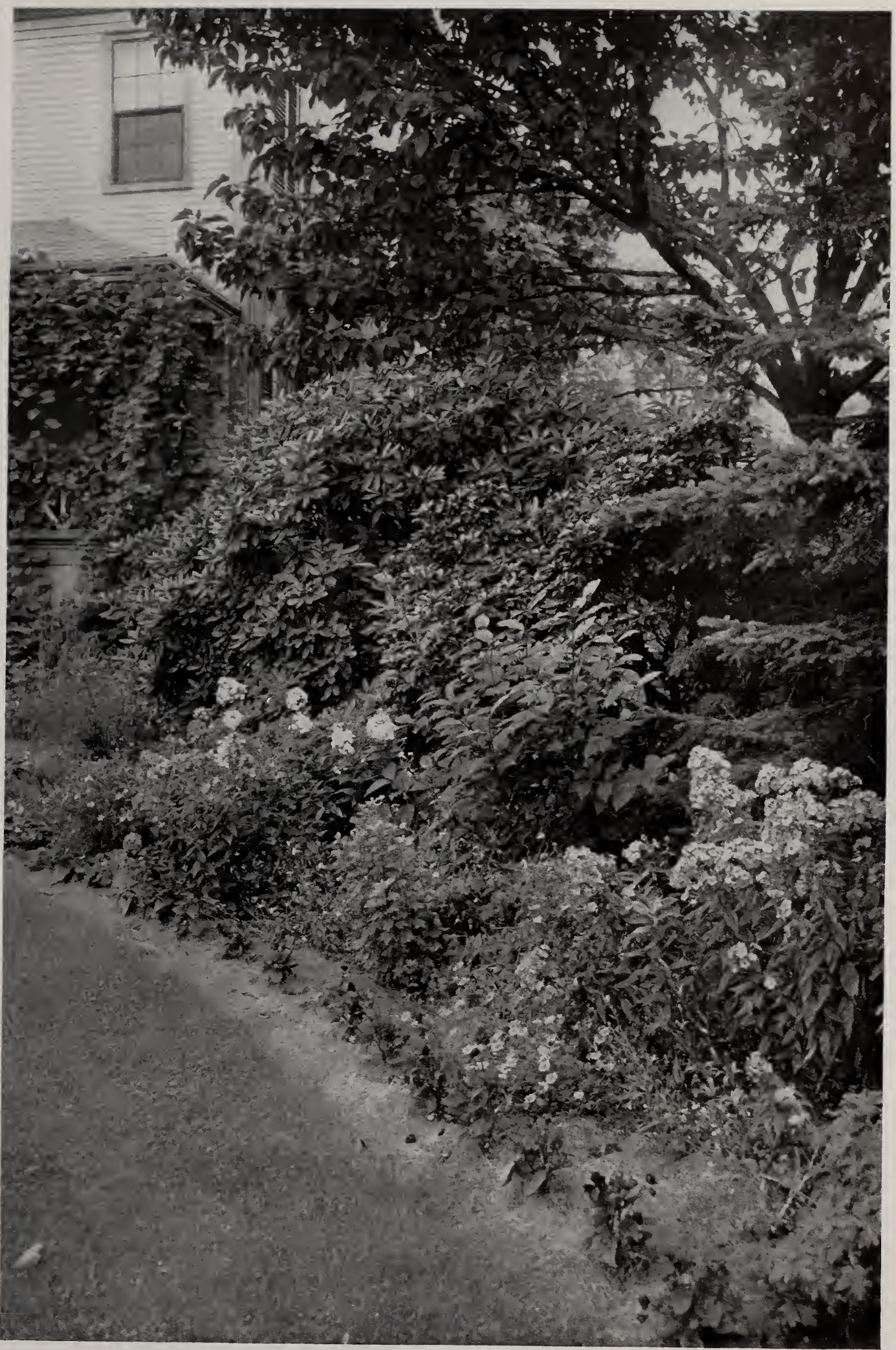




\section{CILTMORE NURSERY WWP}

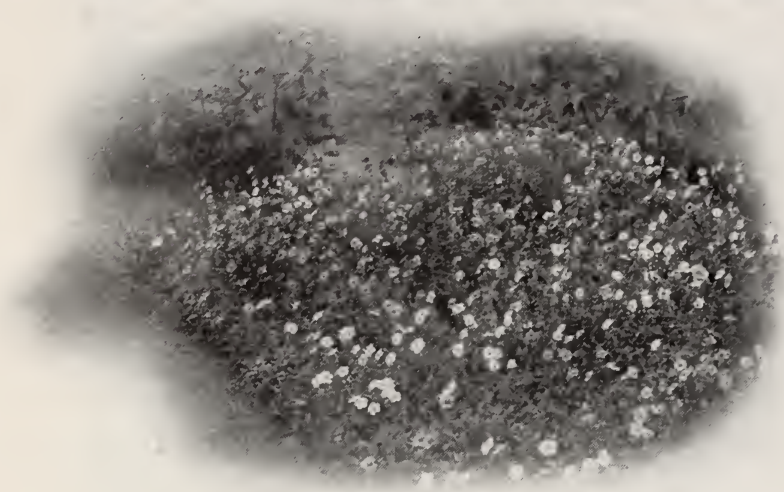

Helianthemum chamæcistus

Galium verum, continued

graceful panicles in summer; their delicate sprays resembling those of the Gypsophila. Valuable for ground covering and rockeries. Strong plants, prepaid, I5 cts. each; larger plants, purchaser paying transportation, $15 \mathrm{cts}$. and $25 \mathrm{cts}$. each.

\section{Gemmingia}

Gemmingia chinensis (Belemcanda and Pardanthus chinensis). BLACKBERRY LILY. This fine old perennial has peculiarly spotted orange-colored flowers, which are produced in clusters at the top of four-foot stems. They close at night and eventually produce a seed capsule so like a Blackberry that they are said to deceive even the birds. The leaves are similar to those of the Iris. Also known as Leopard Lily. Hardy as far north as Chicago with only ordinary winter protection. Strong plants, prepaid, 15 cts. each; larger sizes, purchaser paying transportation, $15 \mathrm{cts}$. and 25 cts. each.

\section{Geranium}

Geranium sanguineum. Cranesbill. The hardy Geraniums are much more graceful than the tender Pelargoniums which have for so long masqueraded under their name, if not so brilliant in blossom. This species, however, has quite large blood-red flowers in great abundance from June to August and is very showy. The branching stems are about $\mathrm{I}^{1 / 2}$ feet high; the leaves are deeply cut, and, like the flowers, have fine stems. Strong plants, prepaid, I5 cts. each; larger sizes, purchaser paying transportation, I5 cts. and 25 cts. each.

\section{Geum}

Geum atrosanguineum. Arexs. A bright-flowered border plant that forms tufted leaf-mats about 8 inches high. The flower-stems rising above them are 18 to 20 inches in length and laden through summer and fall with numerous bright scarlet flowers about an inch wide, curving the stems to half-nodding or trailing habit with their burden. Variable, sun-loving, easy to grow. Strong plants, prepaid, I5 cts. each; larger sizes, purchaser paying transportation, 15 cts. and 25 cts. each.

\section{Gypsophila}

Gypsophila paniculata. BABY's BreATH. A veritable sprite among flowers that at blooming time seems rather to float above the soil than to grow from it. Its grace and airiness are inimitable in the whole plant kingdom. The gauzy tissue of branching stems is sometimes 2 ftet high and spreads diffusely outward into cloud-like sprays that in August and September is sprinkled with minute white flowers so numerous that they seem inseparable. Although so delicate in appearance, this is a perennial of the easiest culture in
Gypsophila paniculata, continued open, rather dry soil, and is sometimes used to cover even waste, unkempt places with a mass of delicate bloom. Its greatest value, however, is to furnish flowers for cutting. To any arrangement of cut-flowers it gives informal, softening touches, toning down with its white lacework colors that seem ton high or too strongly contrasted. Strong plants, prepaid, 15 cts. each ; larger sizes, purchaser paying transportation, is cts. and $25 \mathrm{cts}$. ear.h.

\section{Helenium}

Helenium autumnale. SxeEzeweEd. As showy as some of the Sunflowers and Rudbeckias and useful in the same way. The stems grow 4 to 6 feet high, branch near the top and bloom continually through the autumn months. The drooping rays are fringed at the tips and the disk is cone-shaped.

H. hoopesi. EARLY-FLOWERING SNEEZEWEED. One of the earliest-blooming composites, gay witl clusters of large yellow blossoms from May to September. The flower-heads are orange-yellow, about 3 inches wide, with rays nearly horizontal. Stems I to 3 feet high. Its long-continued season of bloom commends it favorably for keeping up the beauty of the hardy garden.

Either of the above, strong plants, prepaid, $15 \mathrm{cts}$. each; larger plants, purchaser paying transportation, 15 cts. and 25 cts. each.

\section{Helianthemum}

Helianthemum chamaecistus. Rock Rose. A daintily brilliant evergreen creeper, rare yet in American gardens, but useful in so many ways and so easy to grow and so altogether charming that we are glad to help make it better known. Its many small leaves and stems form a thick mat of green over which the loose, half-nodding flower-clusters gleam in a rich embroidery of colors; yellow, red or copper-colored, crimson, and rarely white, with a variety of lovely intermediate shades. It thrives best in a light, well-drained soil and in sunny nooks, blooming best through the warmest season. It has the advantage of being extra strong and hardy. Strong plants, prepaid, I5 cts. each; larger sizes, purchaser paying transportation, 15 cts. and $25 \mathrm{cts}$ each.

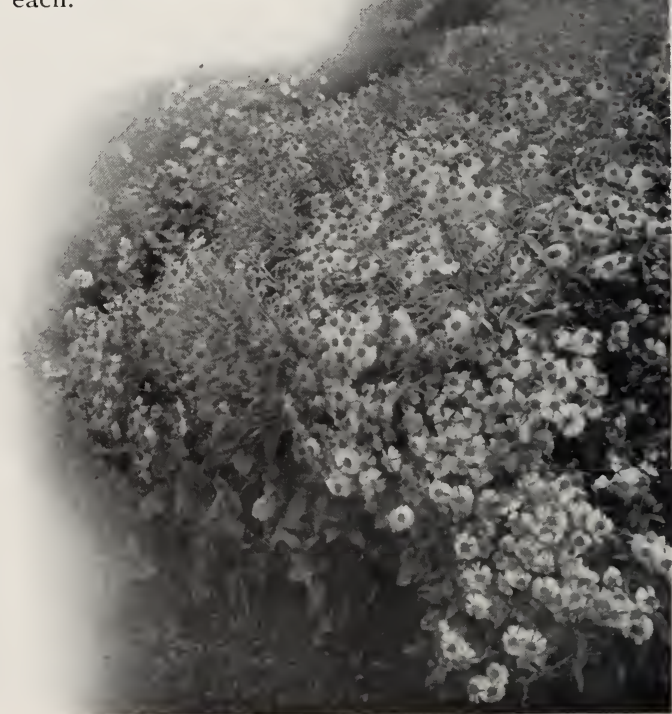

Helenium autumnale 

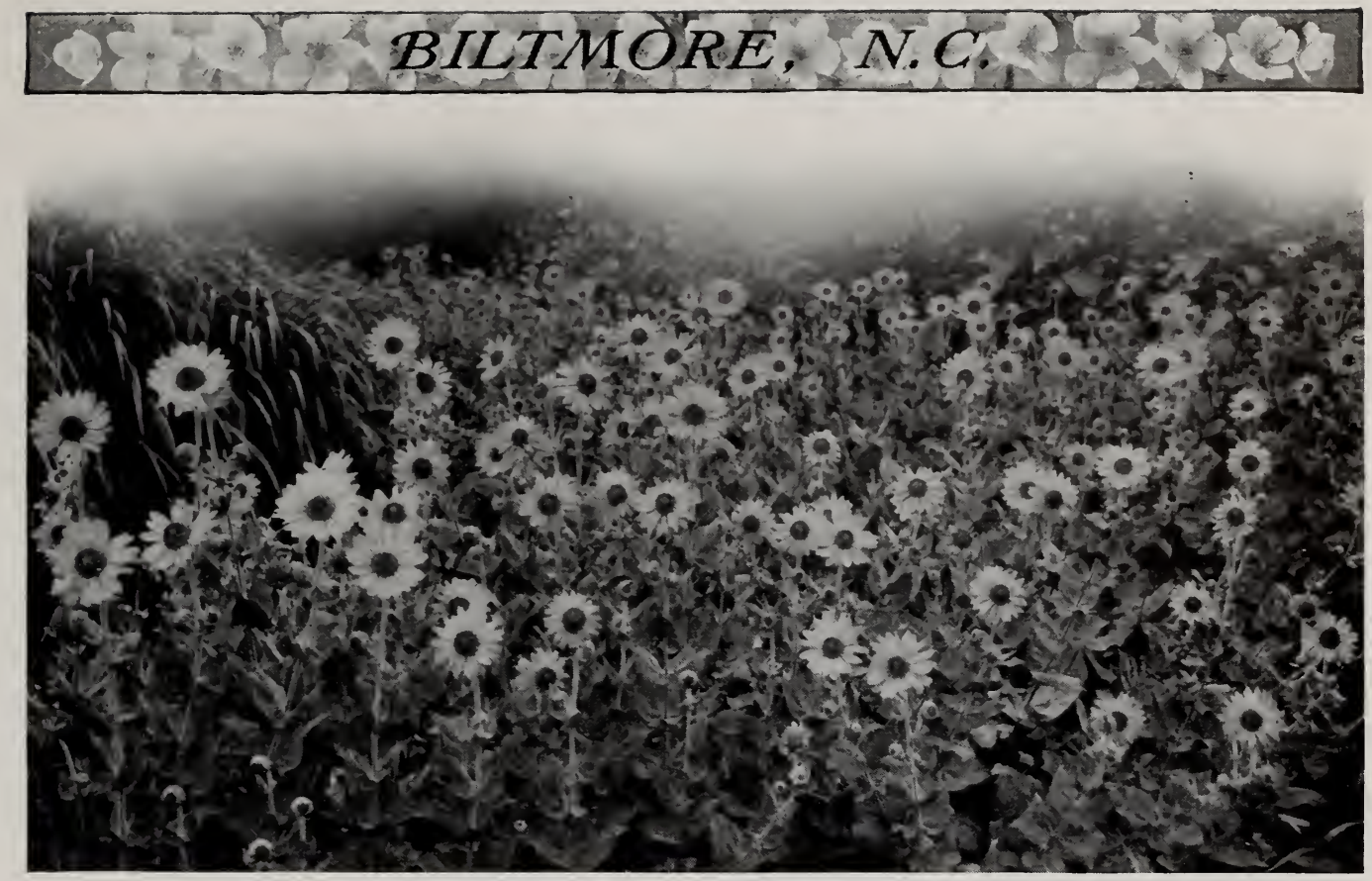

Helianthus mollis, the glory of the autumn months

\section{Helianthus . The Perennial Sunflowers}

Our literature is rich in legends and songs of the Sunflower, which once figured both as a sacred and an artistic emblem. The tall perennial sorts are still "planted for their gilded show" in increasing numbers, for they give a great wealth of picturesque, glittering yellow flowers at a time when the garden could ill spare them. Some of the species have no hint of weediness; in others this quality may be concealed by skillful grouping or forgiven on account of the flowers' brightness. The species below are all bold and erect, growing from 3 to ro feet high and fairly glorifying the autumn months with their gay hosts of blossoms.

Helianthus angustifolius. SWAMP SUNFLOWER. Handsome though rarely seen in cultivation. 2 or $3 \mathrm{ft}$. high.

H. decapetalus maximus. LARGE-FLOWERED PERENNIAL SUNFLOWER. A giantflowered form of the Thin-leaved wild Sunflower and doubtless the greatest flowered of all perennial Helianthus. The leaves are broadlanceolate, the stems 5 to 6 feet high, branching and bearing very large, single, golden yellow flowers 6 to 8 inches across. Superb.

H. decapetalus Soleil d'Or. Double GoldEN SUNFLOWER. A remarkable garden form of the native Thinleaved Sunflower, with flowers resembling those of the Cactus Dahlia.

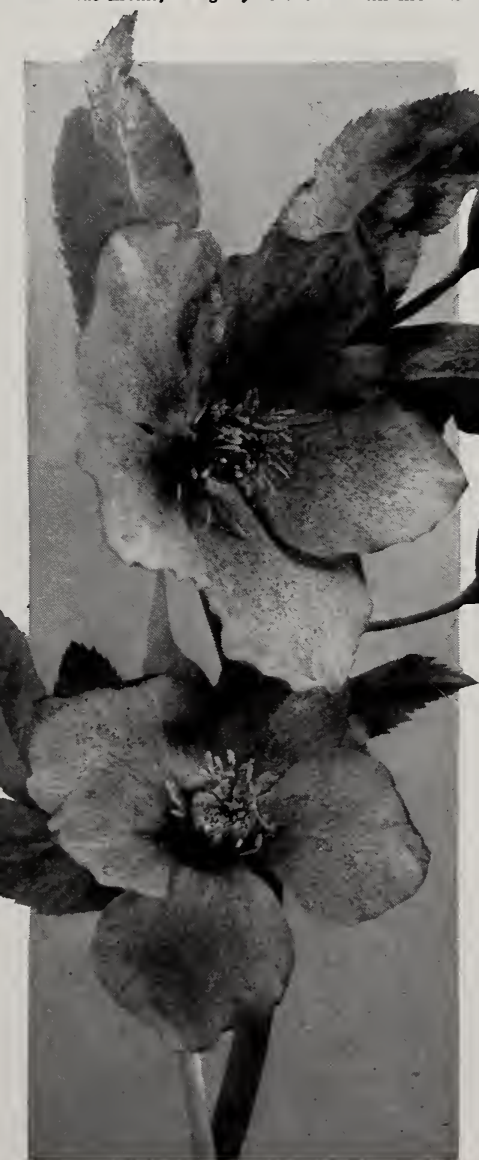

The odd and interesting Christmas Rose, Helleborus niger (see page 32)
Helianthus, continued The large, verydouble golden yellow blossoms open in late summer and autumn, showing bravely on their 4- to 5-foot stems. The petals a re broad pointed and bea $\mathrm{t}$ if u $11 \mathrm{y}$ quilled.

H. mollis. HAIRY SUNFLOWER. Con. trasts large, single, light yellow blooms with lanceolate, dow ny white leaves. 3 to 4 feet.

H. multiflorus flore pleno. DOUBLE HARDY SUNFLOWER. A favorite in gardens for its symmetrical habit, the regularity of its double golden yellow blossoms and the long time they remain perfect. It is always among the most conspicuous of perennials, carrying its great, 5 -foot sheaf of bloom through several weeks of late summer, brightening the garden on the dullest days.

H. orgyalis. LANCE-LEA VED SUN-FLOWER. GRACEFUL SUNFLOWER. Perhaps the most refined and decorative of all this race of perennials. It has distinct, long, narrow leafage, clothing the stems densely and having no suggestion of coarseness. A good root soon forms a large clump, 6 to ro feet high and the upper third-sometimes almost half-of its stature is a waving mass of small lemonyellow flowers, poised lightly on slender stems. It blooms later than most species and is injured 


\section{BILTMORE NURSERY क सही}

Helianthus orgyalis, continued only by freezing weather. Exceedingly effective both for garden and house decoration.

Any of the Hardy Sunflowers, strong plants, prepaid $15 \mathrm{cts}$. each; larger plants, purchaser paying transportation, $15 \mathrm{cts}$. and $25 \mathrm{cts}$. each.

SPECIAL OFFER. A collestion of three Perennial Sunflowers, no two alike, our selection of varieties, strong plants, prepaid, 35 cts.; larger sizes, purchaser paying transportation, 35 cts. and $60 \mathrm{cts}$.

\section{Heliopsis}

Heliopsis pitcheriana. EVERBLOOMING OX-EYE. Fron June until autumn this plant has the most constant flashing yellow of the garden. It is a treasure for dry soils and droughty seasons, which rarely cause it to flag or cease blooming. It grows freely an ywhere, spreading into graceful clumps 2 or 3 feet high. The long, pointed petals of the blossoms are thick in texture and the stems ample, thereby enhancing their value and lasting qualities as cut-flowers. Strong plants, prepaid, I5 cts. each; larger sizes, pur chaser paying transportation, $15 \mathrm{cts}$. and $25 \mathrm{cts}$. each.

\section{Helleborus}

Helleborus niger. CHRISTMAS ROSE. "The most surprising plant of winter," writes Leonard Barron, "is surely the Chistmas Rose, which blooms outdoors amid the snow. Only those who ave had the pleasure of gathering

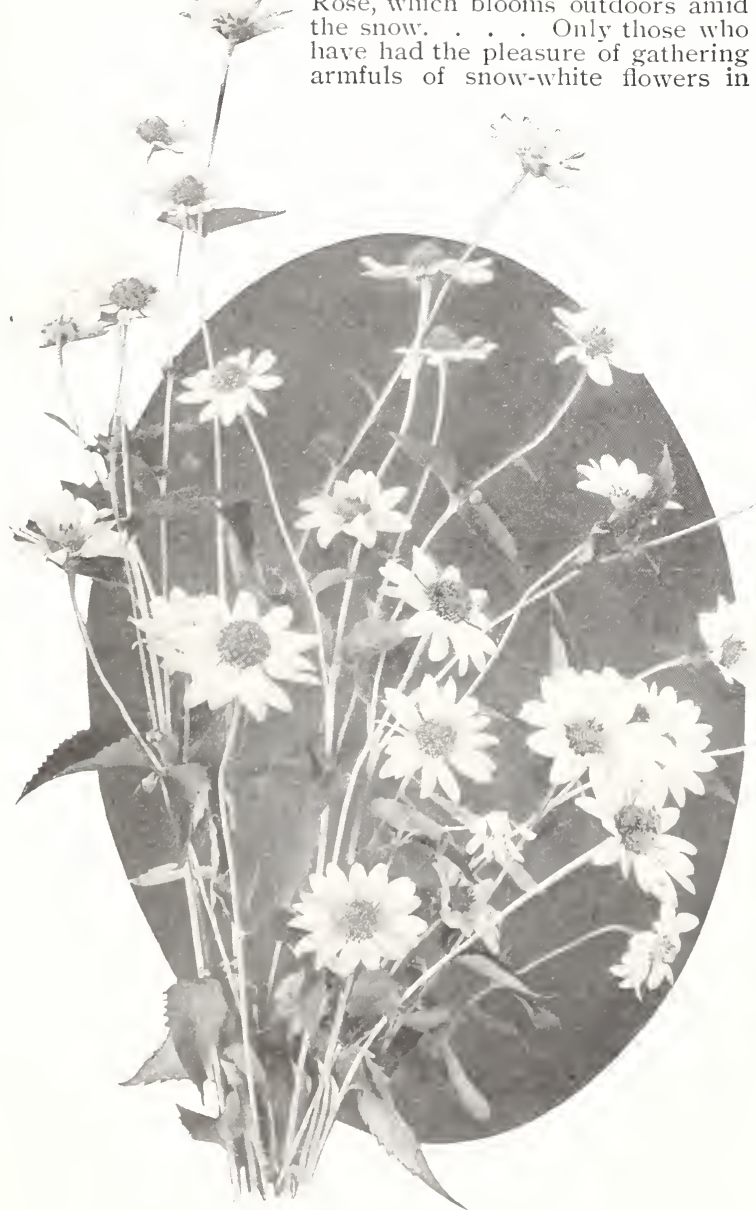

the middle of winter realize what is meant by the possession of a bed of Christmas Roses. The glistening white of the flowers endures for the first few days. For best effects indoors they must be cut before they begin to show pink tinges. . The true Christmas Rose, Helleborus niger, flowering from December to March, is by all odds the most interesting member of this family, all the members of which produce their flowers sometime during the winter or early spring before the very earliest of our other outdoor blossoms begin to open. The Christmas Rose has evergreen foliage, palmately cleft, grows about a foot high, and the pure white flowers, borne two or three on a stalk, are usually about 2 inches across." It is the sepals of this blossom that are showy. A few mild days together at any time from November to March may uncurl the glistening white buds. The culture is something like that of the peony the plants like rich, moist, yet well-drained soils and partially shaded positions best, and to remain undisturbed except for top-dressing over the roots in winter for a long tern of years. Strong plants, prepaid, 25 cts. each; larger sizes, purchaser paying transportation, $25 \mathrm{cts}$. and $35 \mathrm{cts}$. each.

\section{Hemerocallis - The Yellow Day Lilies}

These, like the Funkias or White Day Lilies, are among the oldest and bestloved of garden plants. All species of Hemerocallis have narrow grass-like leaves, instead of broad ones, as in the White Day Lily, and their blossoms are borne in corymb-like panicles instead of racemes. The flowers, too, have widler funnels than those of the Funkias and a less pervading but pleasant fragrance. The individual blooms are short-lived, but there is a good succession of them for most of the season, if all the better sorts named below are planted. The colors are in various shades of yellow-rich, soft tones shading to orange, or clear, pure, golden ones. The roots are semi-tuberous, very hardy and persistent. They need no winter protection and thrive in any good soil, preferring, however, a rich. moist loam. For garden borders and waterside Heliopsis pitcheriana planting few perennials are more satisfactory. 


\section{BILTMORE, N:C. P \&}

Hemerocallis, continued

Hemerocallis aurantiaca. FRAGRANT ORANGE L1LY. Distinguished by its quite large flowers of bright orange, which are 5 or 6 inches across, and open in late summer. The leaves are long and relatively broad; stems about 3 feet high. Strong plants, prepaid, $25 \mathrm{cts}$. each; larger sizes, purchaser paying transportation, 25 cts. and 35 cts. each.

H. dumortieri. DWARF ORANGE LILY. Handsome, short-tubed orange-colored blossoms, flamed with velvety maroon on the outside of the petals. Blooms earlier than most other species. Stems I to 2 feet high.

H. flava. LEMON LILY. A good clump of this fine old lily, when blooming in June, lights up the border superbly with many tall stems of fragrant, waxen, clear yellow blooms. It is one of the most satisfactory and delightful of all hardy flowers.

H. fulva. TAwNy DAY LILy. Very showy in late summer, when its tawny orange blossoms open on 3to 4 -foot stems. So vigorous that it will soon dispossess some of our weed pests in waterside planting.

H. fulva kwanso. DOUBLE ORANGE LILY. A doubleflowered form of the Tawny Day Lily, more effective for bright color patches, as the plants bloom longer and the flowers are more durable.

H. thunbergi. LATE-FLOWERED LEMON LILY. Differs from the beautiful old Lemon Lily chiefly in the later production of its wealth of pure golden yellow blossoms, which appear in midsummer.

Any of the above, unless otherwise noted, strong plants, prepaid, 15 cts. each; larger sizes, purchasec paying transportation, $15 \mathrm{cts}$. and $25 \mathrm{cts}$. each.

SPECIAL OFFER. One each of the Yellow Day Lilies, six in all, strong plants, prepaid, 85 cts.; larger sizes, purchaser paying transportation, $85 \mathrm{cts}$. and $\$ 1.35$.

\section{Hesperis}

Hesperis matronalis. SwEET ROCKET. DAME'S VIOLET. A bright and fragrant-flowered old-time plant, forming clumps 2 to 3 feet high, branched from the base and lighted by showy terminal pyramids of 4-pet-

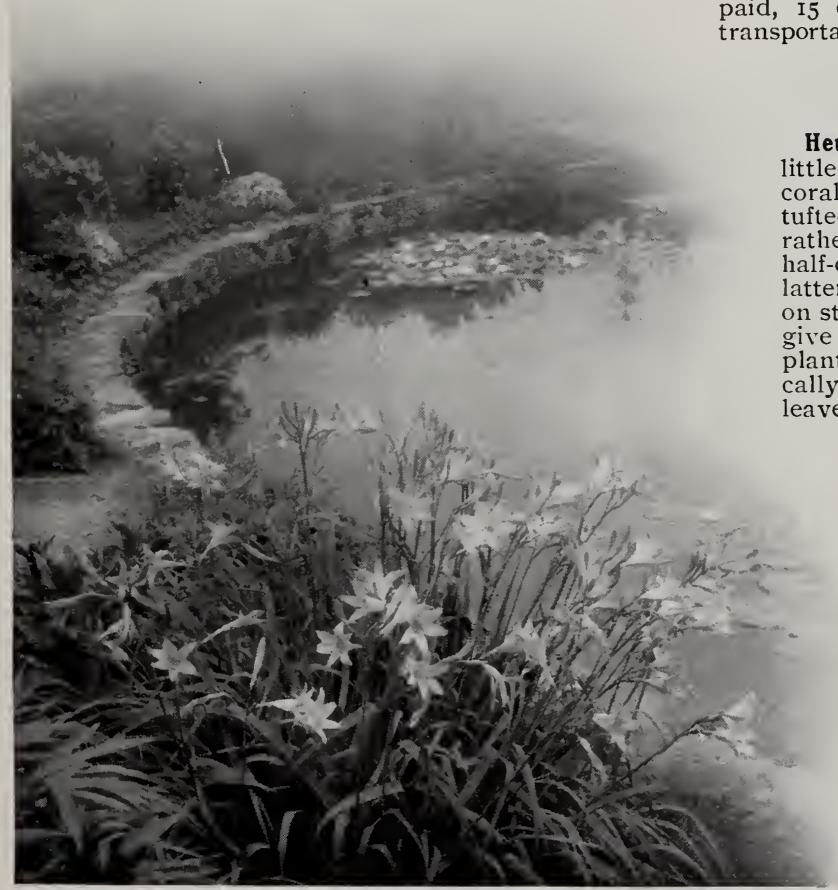

Hemerocallis flava

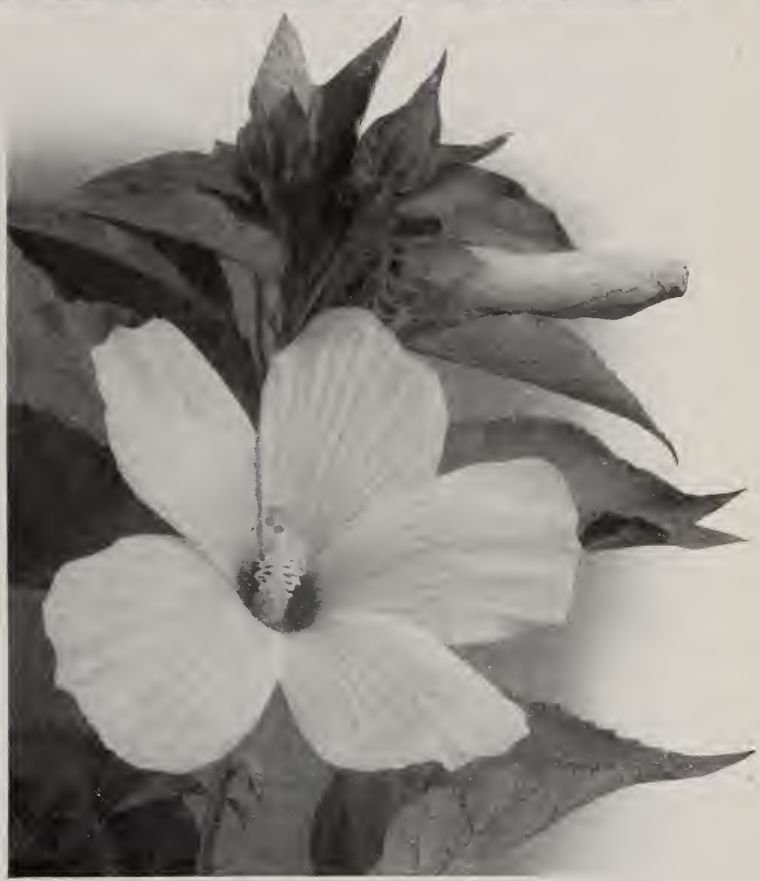

Hibiscus moscheutos (see page 34 )

Hesperis matronalis, continued aled blossoms resembling Stocks. In warm climates or sheltered positions the blossoming begins in April and extends into June; a good bed of plants showing white, pink, various shades of lilac and purple in its flowers. With us the leaves are bright green through winter and the plant an excellent one for rocky banks or naturalizing in wild gardens. Strong plants, prepaid, I5 cts. each; larger sizes, purchaser paying paid, I5 cts. each; larger sizes, purch
transportation, I5 cts. and $25 \mathrm{cts}$. each.

\section{Heuchera}

Heuchera sanguinea. CORAL BELLS. A dainty little plant, with delicate, long, slender spikes of coral-scarlet flowers rising from its evergreen, tufted and brightly marbled foliage. Although of rather recent introduction it ranks among the half-dozen best plants with small red flowers. The atter are shaped like Lilies-of-the-Valley, borme on stems a foot or more high in loose panicles, and give a very delicate, airy effect. One of the best plants for the hardy border, as it blooms practically all the season, and has attractive winter leaves. Strong plants, prepaid, I5 cts. each ; larger sizes, purchaser paying transportation, $15 \mathrm{cts}$. and $25 \mathrm{cts}$. each.

\section{Hibiscus . The Rose Mallows}

The Rose Mallows are tall and shrub-like in effect, stiff stems and broad, handsome leaves being needed to present well their great pink, white, or lavender-colored flower-bowls, which measure, in some species, 5 to 8 inches across and may be either self-colored or darker centered. The roots are remarkably long-lived and vigorous, sending their stems to a height of five or six feet and keeping them aglow with great flowers all 


\section{Q BILTMORE NURSERY Y XEA}

Hibiscus, continued

through midsummer. Ideal plants for bold effects near streams or pools, which reflect the great bright blossoms.

Hibiscus militaris. HalBert-Leaved Rose MALLOW. The flowers of this species are from 3 to 5 inches across and delicate pink or light rose, with a dark, velvety center. The handsome leaves are lobed near the base; the stems are 4 to 6 feet high.

H. moscheutos. Rose MALLOW. Most showy of all the species, with superb flowers 5 to 8 inches across, pure pink, white, or lavender self-colored, or else with darker centers. The leaves are downy-white beneath ; the stems 3 to 5 feet high.

H. oculiroseus. Crinson-eyed Hibiscus. Similar to the Rose Mallow, but with huge flowers of creamy white, having large crimson centers.

Any of the Rose Mallow, strong plants, prepaid, 25 cts. each; larger sizes, purchaser paying transportation, $25 \mathrm{cts}$. and $35 \mathrm{cts}$. each.

SPECIAL OFFER. One each of the Rose Mallow, as above, strong plants, prepaid, $60 \mathrm{cts}$.; larger sizes, purchaser paying transportation, $60 \mathrm{cts}$. and $85 \mathrm{cts}$.

\section{Hudsonia}

Hudsonia montana. MOUntain Hudonia. A bushy, shrubby, little plant, 4 or 5 inches high, with awlshaped leaves scattered along its branches and small but showy bright yellow blossoms crowded along their tips. This quaint and rare plant, native of the Caroina mountains, is beautiful for carpeting rockeries or rough wild spots with its almost evergreen leaves, and in places where grass will not thrive it soon covers the ground with its dainty foliage, forming a solid mat of green almost the year through. Blooms in May and June. A gem, both in rarity and excellence. Strong plants, prepaid, 25 cts. each; larger plants, purchaser

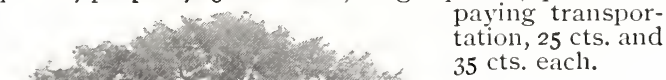
25 cts. and

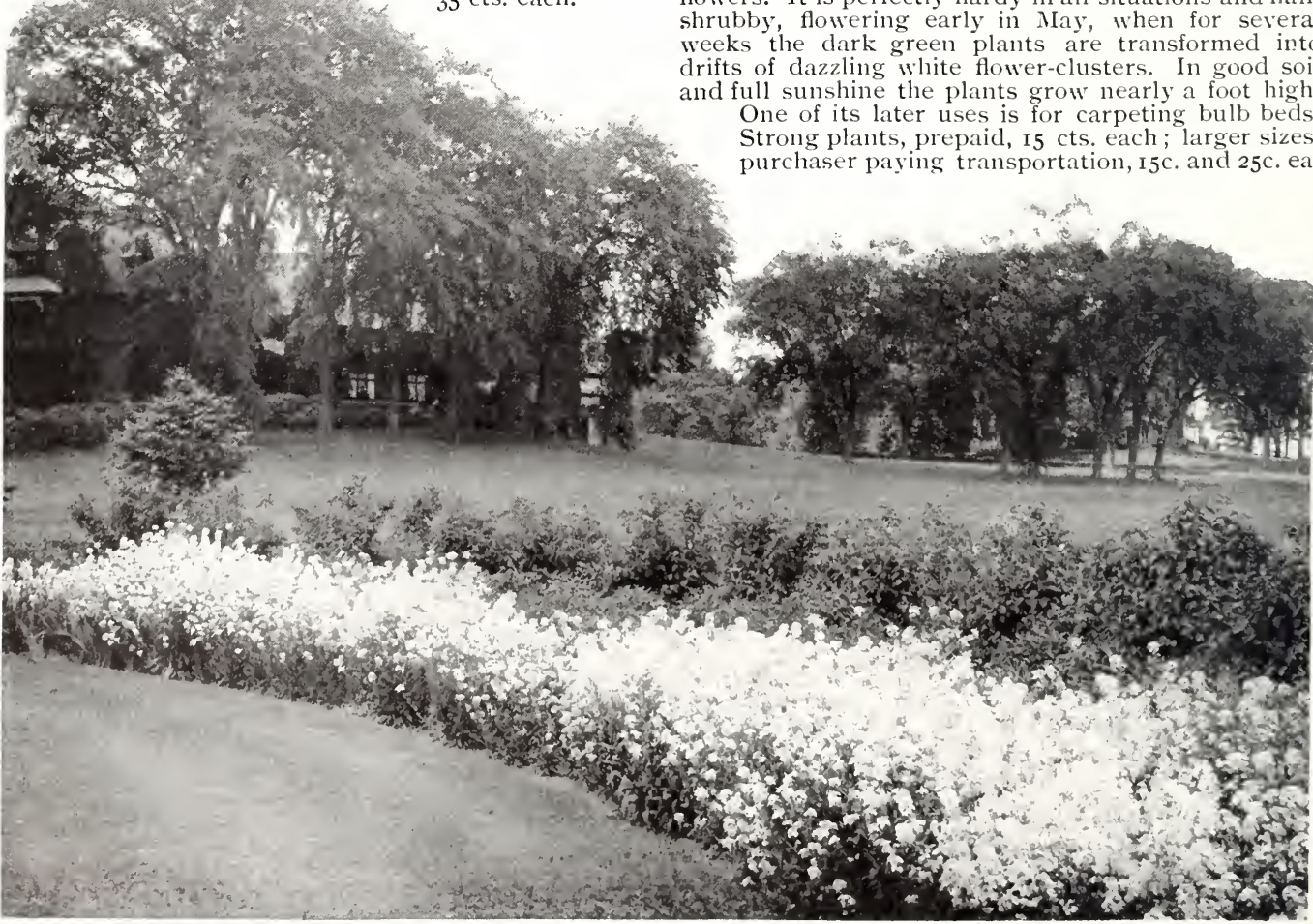

Hesperis matronalis, a bright and fragrant-flowered old-time plant (see page 33)

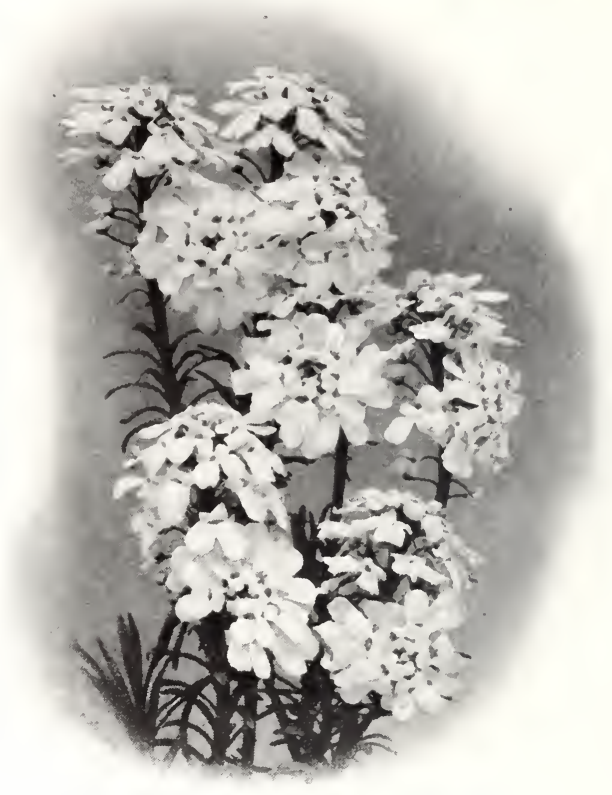

Iberis sempervirens

\section{Iberis}

Iberis sempervirens. EVERGREEN CANDYTUFT. This Iberis is one of the most charming of evergreen rockplants, the coolest-looking of the spreading spring flowers. It is perfectly hardy in all situations and half shrubby flowering early in Nay, when for several cels the dark green plants are transformed into rifts of dazzling white flower-clusters. In good soi

trong plants, prepaid, I5 cts, each; larger sizes, 


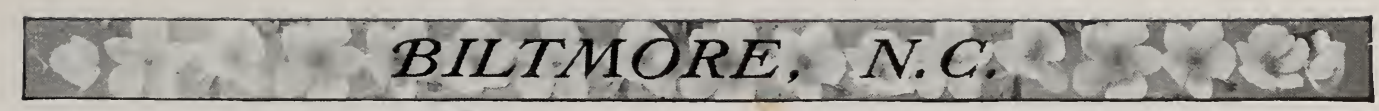

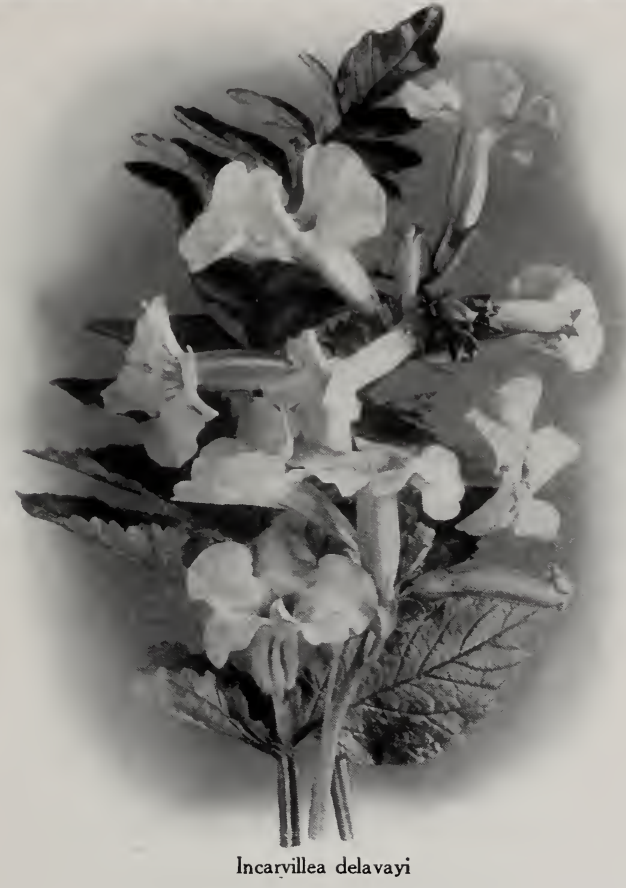

Incarvillea

Incarvillea delavayi. HARDY GLOXINIA. The large and remarkably handsome flowers of this perennial resemble those of the Gloxinia and Bignonia. They are borne on scapes from I to 2 feet high from the center of a rich cluster of pinnate leaves about a foot in length. The flowers are trumpet-shaped, with yellow, tubular throats and spreading rosy purple petals; they are 2 to 3 inches long and borne in showy clusters. A protection of leaves or litter is needed in winter in cold climates. Strong plants, prepaid, $25 \mathrm{cts}$ each; larger sizes, purchaser paying transportation, $25 \mathrm{cts}$. and $35 \mathrm{cts}$. each.

\section{Iris · Fleur de Lis}

The Iris is a flower of song and story, having a long train of associations for nearly all who plant it in their gardens. Although some of its species can show flowers larger than those of any other hardy perennial, it is not mere size and showiness that have made it perhaps the best-loved and most largely grown of all herbaceous plants. Its classical beauty of structure, purity and delicate richness of color, and unusually beautiful combinations of tints and shades, are unparalleled among flowers. Through a long season, too, these strange, rich flowers are plentiful. The low blue stars of the little dwarf Iris cristata begin to twinkle over rocks and sunny slopes before the gold of the Daffodil is yet dim. Iris pumila follows closely with larger flowers more boldly displayed. In May the German Iris is queen of perennials, followed by the Siberian Irises of June, and in July the great Japan Iris, now grown in grand collections, draws crowds of people to see a flower-show finer than any ever spread under glass. All these species are hardy and of the easiest culture, thriving best in rich, moist loam and sunny exposures. If, perchance, your garden has a pond or brookside, the Irises will love it and make its banks more beautiful than any other flower could. But if the garden is on a dry hilltop they will

\section{Iris, continued}

Hourish there, too, giving almost as much beauty for a little more care in fertilizing, planting and watering. As the clumps increase in size, liberal mulching and occasional replanting will be repaid by larger and richer flowers in greater numbers.

Iris cristata. CRESTED IRIS. Smallest and daintiest of all the Irises, but sending up its short flower-stems so thickly over a wide mat of grass-like leaves that its light blue blossoms make bright flakes of color both cheery and conspicuous in early spring. The larger outer segments of the flowers have a bright orange crest.

I. florentina, ORRIS ROOT. The Florentine Iris, usually called white, though its petals are tinged with lavender just enough to give a silvery effect, opens its fragrant flowers a little earlier than the German varieties. Its dried root is the orris root of commerce. A distinct and always desirable species.

I. germanica. GERMAN IRIS. FLEUR DE LIS. The great bearded Iris is one of our border royalties, born to the purple, indeed, and to almost all the other beautiful colors obtainable in a flower. It has large, bright, glaucous leaves and usually three or four large flowers to a stem ; the latter may be from I to 2 feet high, according to soil and variety. The center of the flowers is hidden by three petals, or "crests," rising above it ; three others, broader and richly marked - the "falls" -droop between them. Their blooms last several days when cut just before expanding and make excellent decorative material. With care a good clump may be lifted while the leaves are yet small and flowered in a jardinière on the porch or indoors. We offer a superb strain of assorted colors as well as the following:

Amas. Inner segments sky-blue, the outer segments deep violet. A splendid variety.

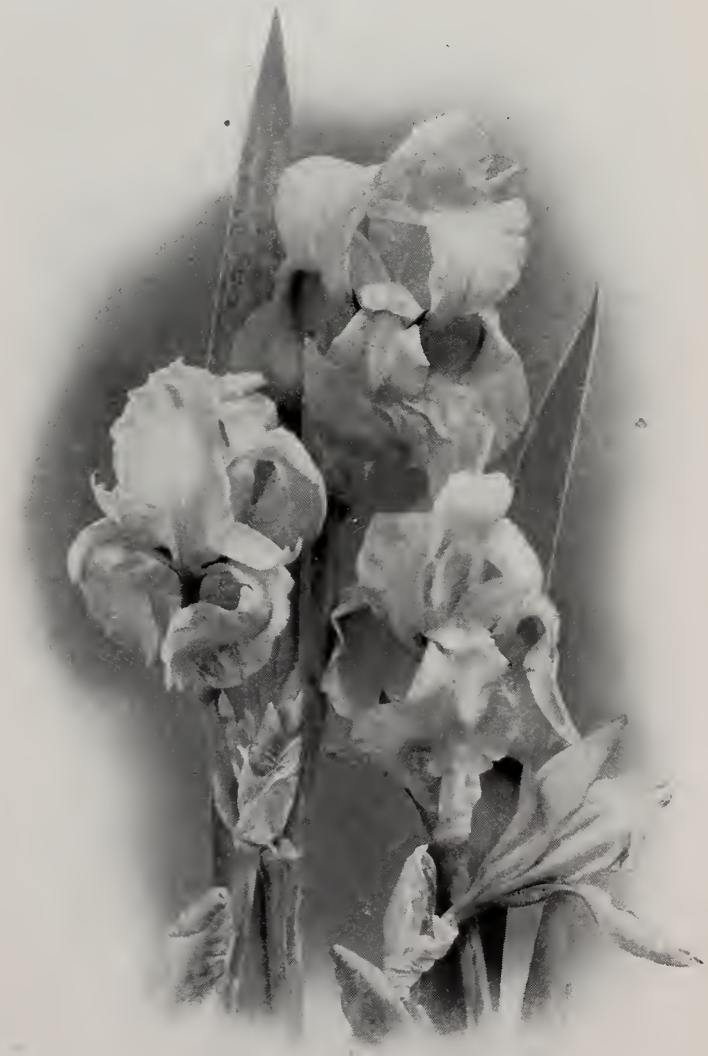

Iris florentina 


\section{BILTMORE NURSERY \& WO}

Iris germanica, continued

Benacensis. Flowers very large and showy, deep blue and purple.

Bridesmaid. White suffused with blue.

Cordelia. Inner segments lavender, the outer segments with a heary purple blotch on lavender ground. Extra fine.

Golden King. The deepest colored of the yellow forms.

Magnifique. Inner segments golden yellow, the outer very dark brown. Sujerl.

Mme. Chereau. White, beatutifully edged with blue. One of the most charming forms.

Prince of Wales. Pure white. A grand varicty.

Queen of May. Bright rosy lilac. Tall and handsome.

Sans Souci. Golden yellow and chocolate.

Spectabilis. Rich purple. A grand roval flower.

Victorine. White, flaked with riolet.

Any of the named varieties of Iris germanica, strong plants prepaid, 25 cts. each; larger sizes, purchaser paying transportation, 25 cts. and 35 cts. each.

SPECIAL OFFER. One each of the named varieties of German Iris, strong plants, prepaid, \$2.50; larger sizes, purchaser paying transportation, $\$ 2.50$ and $\$ 3.50$.

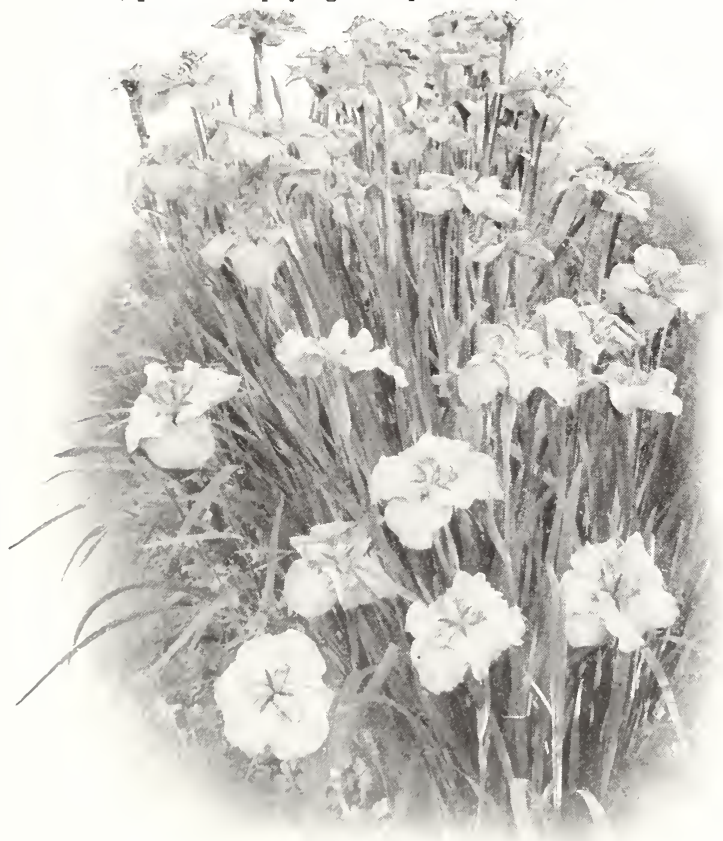

Iris sibirica (see page 37 ,

Iris lævigata, continued

white, deep blue, purple, lavender-pink, lilac, maroon and many rich combinations of these colors. In addition to all its other charms, the Japanese Iris is so supremely hardy that it requires no protection in the coldest winter, and multiplies with amazing rapidity. We offer a superb collection of mixed varieties of richest and most delicate colors, as well as the named sorts which follow:

\section{Double-flowered Forms}

Artist. Lavender ground with violet-blue penciling.

Cassy. White, heavily penciled with sky blue.

Clarissa. Rosy purple, shading to white.

Defiance. Rich velvety crimson-purple.

Delicata. Pale mauve, shading to white.

Empress Queen. A grand large white.

Evelyn. Delicate rosy mauve, marbled and mottled on lighter ground.

Grand Duchess. Rich blue, with vellow center.

Lady Ardilaun. White, bordered with rosy purple.

Lady Roberts. Rosy purple, with white veins and yel-

low center.

Picturata. White, with a broad border of rosy purple.

Portia. White, delicately veined with purple.

The great, lightly poised blossoms of Iris lævigata

Iris laevigata. JAPANESE IRIS. "It is little wonder," writes Neltje Blanchan, "that a plant so boldly decorative in outline and bearing a flower of exquisite coloring so marvelously formed slould make its strongest appeal to the artistic Japanese. From these foremost gardens of the world has come a strain of Irises that neither Orchids nor Lilies can rival in beauty of form, texture, coloring, marking or general effectiveness. Naturalized in the water garden, where the tall, narrow leaf-blades rise in phalanges round the shore and the stately beauty of the flowers is reflected in the water below, they are idleally situated; but let no one forego the delight of growing Japanese Irises merely for lack of a pond or stream. Some exceedingly fine specimens have been grown in a city back-yard." The long, bright green leaves of the Japanese Iris are much overtopped by their 2- to 3 -foot bloom-stems, on which float great, lightly poised blossoms 6 to 9 inches across,

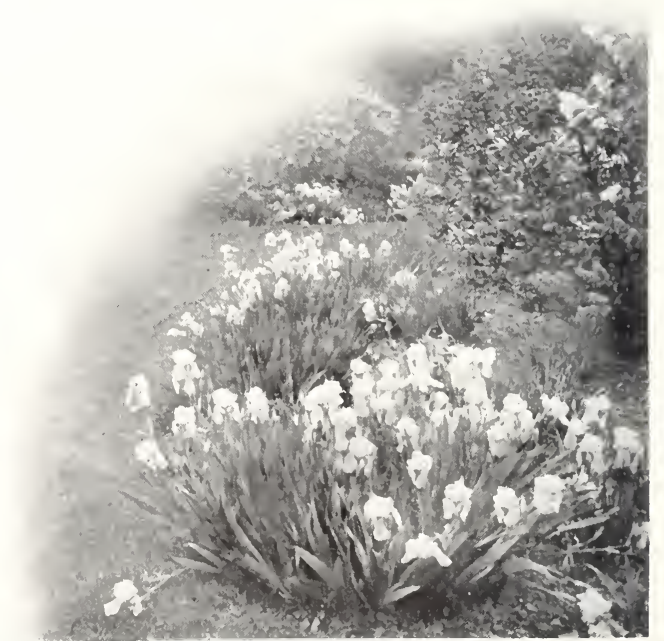

A strong clump of Iris germanica 


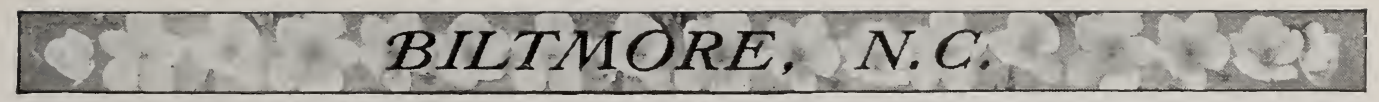

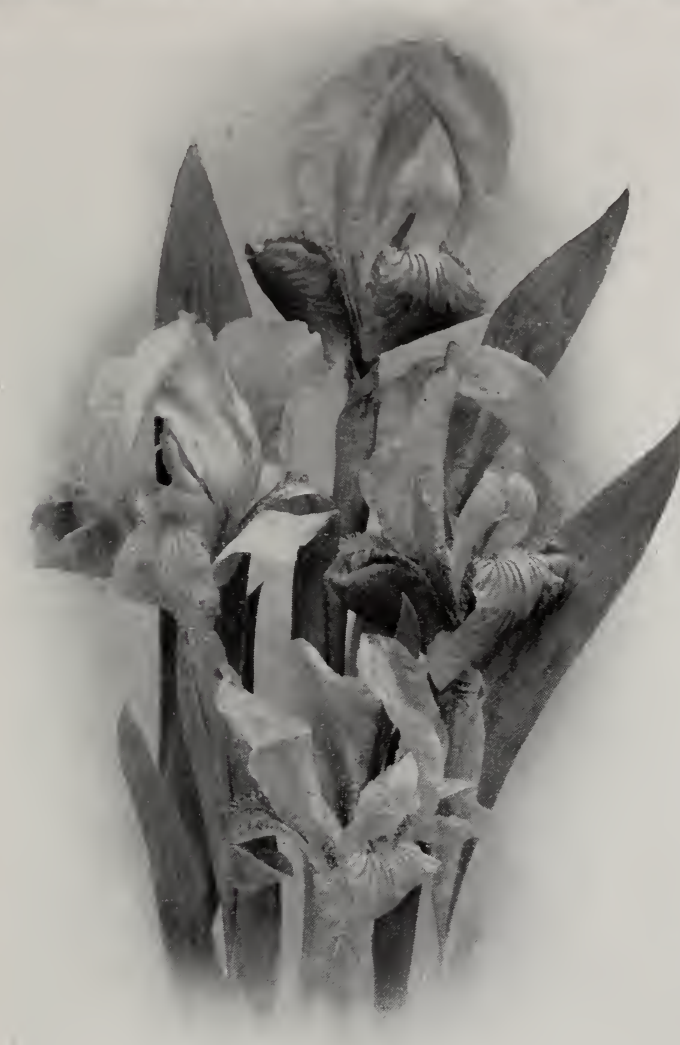

Iris pumila

\section{Iris, Single-flowered Forms}

Agnes. Large, pure white.

Bride. Superb white flowers.

Constance. White, suffused and bordered with rosy purple.

Esther. Light rose, veined and tinted with purple.

Favorite. IWhite, delicately washed with pale blue.

Lady Margaret. Bright rose, with a white and yellow center. Charming.

Meta. Grayish white with bluish purple veins.

Rosea. Clear silvery rose. Perfect in tone.

Splendor. Pale rosy lilac, with deeper marks. Superb.

Sprite. Bright blue, splashed with lighter shades.

The Queen. Extra large, pure white.

Violescens. Rich purple, very free-flowering.

Prices of the named varieties of Iris laevigata, strong plants, prepaid, $25 \mathrm{cts}$. each; larger sizes, purchaser paying transportation, $25 \mathrm{cts}$. and $35 \mathrm{cts}$. each.

SPECIAL OFFER. Twelve named varieties of Japanese Iris, any of the sorts, your selection, strong plants, prepaid, $\$ 2.50$; larger sizes, purchaser paying transportation, $\$ 2.50$ and $\$ 3.50$.

I. missouriensis. Western Blue Flag. The bright lilac flowers of this species have a yellow center and are borne on stems I to 2 feet high, somewhat taller than the pale green, delicately ribbed leaves. Native to our Western states. Blooms early.

I. pumila. EUROPEAN DWARF IRIS. The narrow leaves of this pretty dwarf are from 2 to 4 inches long and very early in spring the white, violet or purple flowers appear just above them quite abundantly. It makes a fine edging plant for borders if grown in a broad line and also looks well in masses. A good species, too, for slow forcing in bulb pans in winter.

I. sibirica. SIBERIAN IRIS. Tall and slender-growing,
Iris sibirica, continued

with flowers like those of the German Iris in structure, but smaller and much more numerous. The plant forms large, strong, compact clumps and blooms so freely that its deep blue blossoms give solid color effects.

I. verna. AMERICAN Dwarf IrIS. This slender little dwarf opens its fragrant blue flowers early in April or May. The segments are crestless and brightened with touches of yellow; the odor is like that of Violets. The leaves are narrow and somewhat taller than the flowers which nestle among them.

I. versicolor. BLUE FLAG. A handsome native species, with large and showy blossons of violet-blue, purple-veined and sometimes variegated with green, yellow or white. One to 3 feet high, with stout stems and sword-shaped leaves.

Any of the Irises, except where noted, strong plants, prepaid, 15 cts. each; larger sizes, purchaser paying transportation, $15 \mathrm{cts}$. and $25 \mathrm{cts}$. each.

SPECIAL OFFER. A collection of six distinct species of Iris, our selection of varieties, strong plants, prepaid, 75 cts.; larger sizes, purchaser paying transportation, 75 cts. and $\$ 1$.

\section{Lathyrus}

Lathyrus latifolius. PERENNiAL PEA. A very permanent, vigorous vine that climbs to a height of about 5 feet. The foliage is similar to that of the Sweet Pea and persistent through winter; the blossoms are white or rosy and about the size of the Sweet Pea's, but borne in much larger clusters and scentless. So rampant growing that its chief use is as a trellis plant or for covering wild rough places which it masks with a web of beauty. Grows rapidly even in shaded and sterile spots, but is impatient of removal or disturbance. Strong plants, prepaid, 15 cts, each; larger sizes, purchaser paying transportation, I5 cts. and $25 \mathrm{cts}$. each.

My order of plants came promptly and safely. I am pleased and hope they will fulfil my expectations. Very truly, Miss ElizaBFTH Lewis, Bridge-cote, I7I2 Yale Avenue, Knoxville, Tenn., November 9.

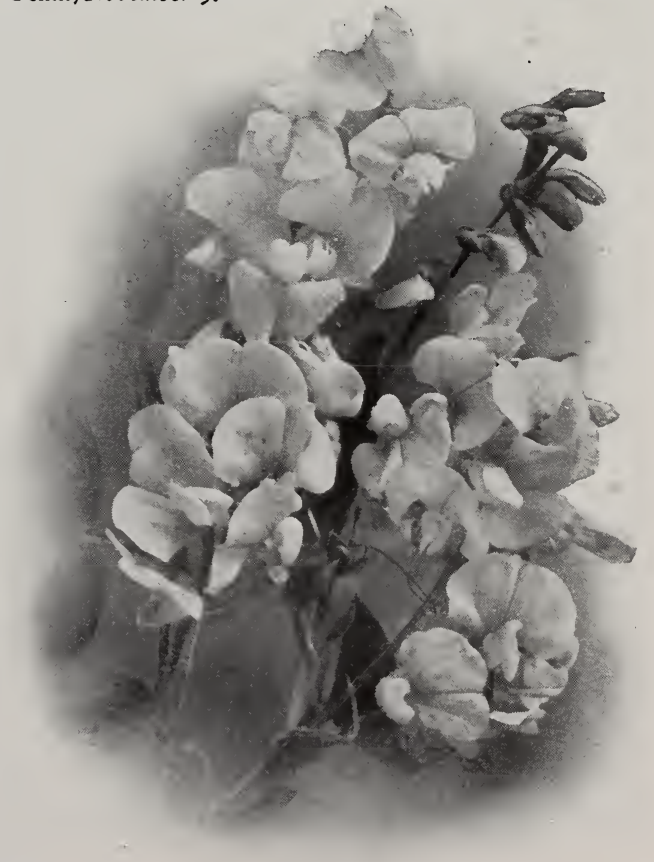

Lathyrus latifolius 


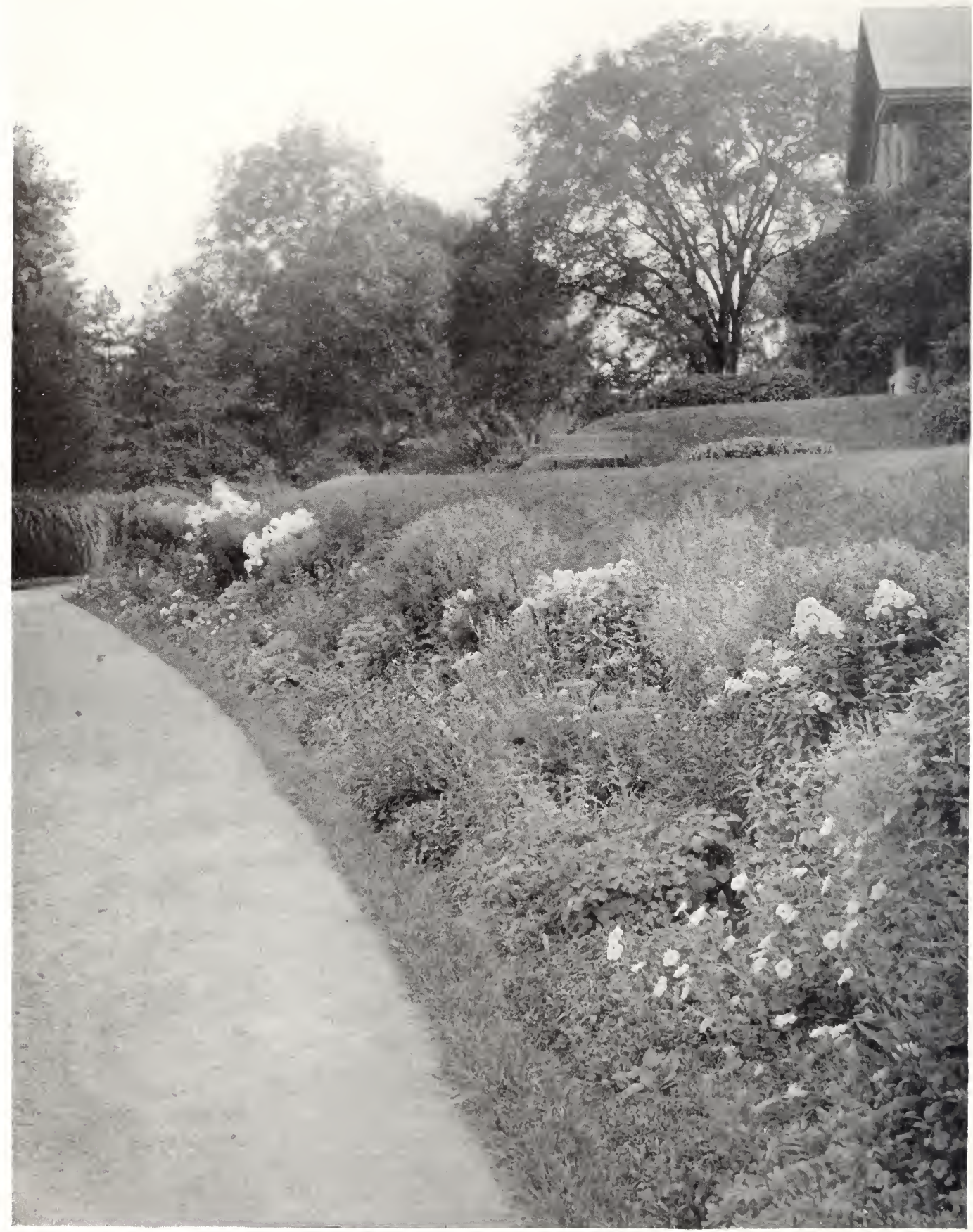

The garden retreat, cool and restul 


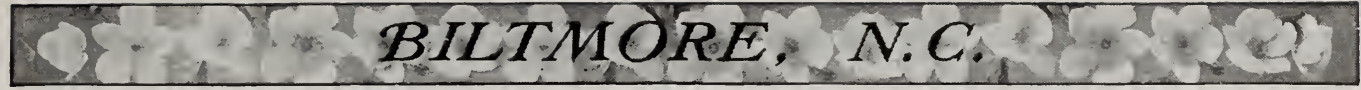

\section{Lavandula}

Lavandula vera. TRUE LAVENDER. The silvery downy leaves of the Lavender give us the most delicate and delightful of garden perfumes, while from its abundant terminal spikes of flowers originated the soft and charming tint known as lavender-blue. The plant is much branched and densely leafy, tufts of smaller leaves often springing from the axils of the larger ones. In favorable climates these beautiful fragrant leaves are persistent, of nearly so, making the Lavender an ideal edging plant. Lavender walks are a famous feature of English gardens, where the plant sometimes grows 4 feet high. It is hoped that in portions of our own country, where the Lavender proves hardy and evergreen, similar ones may be enjoyed. Here it grows from 2 to 3 feet high and thrives best in a light, well-drained soil fully exposed to the sun. In colder sections it needs a winter protection of coarse iitter or evergreen boughs. Strong plants, prepaid, I5 cts. each; larger plants, purchaser paying transportation, 15 cts. and 25 cts. each.

\section{Lespedeza}

Lespedeza japonica. WHITE-FLOWERED LESPEDEZA. A pretty, shrubby perennial of the easiest culture, that soon forms dense clumps of strong, wiry shoots and a mound of beautiful light green leafage that is attractive all the season. In September and October every twig of these numerous stems droops with pretty racemes of pure white flowers. The leaves are compound, as in Clover, each one having three small leaflets. One of the best perennials for adding variety and late bloom to the border.

L. sieboldi (Desmodium penduliflorum). SiebolD's D. syodiur. The rose-colored Desmodium blooms a week or two earlier than the white, has darker leaves and is much showier, if not so dainty. Its clustered stems arch gracefully from a height of 2 or 3 feet and its very numerous flower-stems, panicled near the top of the plant, droop in cascades of long, rose-pink racemes over the bright green, airy mass of leaves with exquisite effect.

Either of the Lespedezas, strong plants, prepaid, 15 cts. each; larger sizes, purchaser paying transportation, $15 \mathrm{cts}$. and $25 \mathrm{cts}$. each.

SPECIAL OFFER. One each of the Lespedezas, as above, strong plants, prepaid, 25 cts.; larger sizes, purchaser paying transportation, $25 \mathrm{cts}$. and $40 \mathrm{cts}$.

The stock was duly received and I am well pleased with it. Shall be glad to report to you later what surcess I have with the several plants, as I am looking forward with a greal dea of pleasure to the flowering season. Yours truly, MrS. D. E. SPANGle R, Roanoke, Va., November 2, 1909.

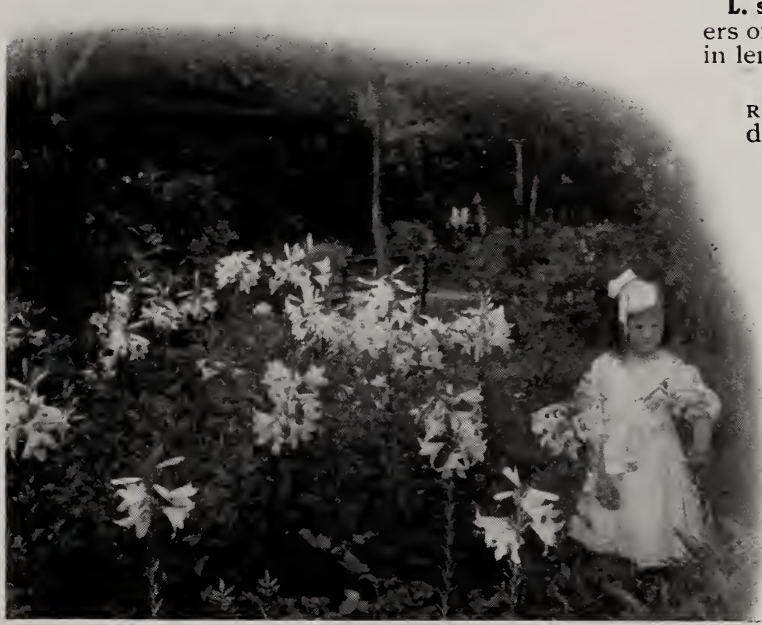

Lilium candidum, one of the most permanent of all (see page 40)

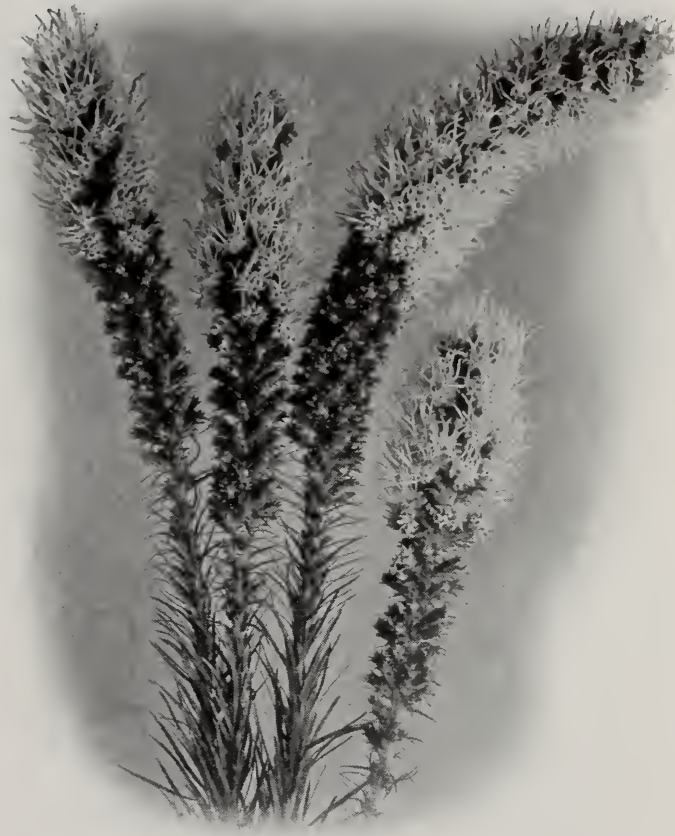

Liatris pycnostachya

\section{Liatris}

A fine, tall and permanent type of perennials, with flowers of such unusual brilliancy as to win for them the name of Blazing Star. The blossoms are set thickly along wand-like spikes, or racemes, several feet in heighi, in late summer and autumn. A good mass of Liatris always attracts attention, and is usually the brightest bit of autumn color in the garden.

Liatris pycnostachya. KANSAS GAY FEATHER. Very odd and striking, as well as very beautiful. The slender bloom-spikes appear in August and September, growing 5 to 7 feet high. Their light, rosy purple blossoms are often surrounded by butterflies.

L. scariosa. LARGE Buttox-Sxakfroot. The flowers of this species are deep purple, in spikes 3 to 4 feet in length.

L. spicata. Dense-flowered Button-SnakeROOT. Lower-growing, with purplish flower-spears densely set with bloom and from 6 to 12 inches long. Strong plants of the above, prepaid, 15 cts. each; larger sizes, purchaser paying transportation, 15 cts. and 25 cts. each.

\section{Lilium - The Hardy Lilies}

In some of the older gardens we find fine examples of the use of Lilies. Some of the original clumps are blooming still, for Lilies are more permanent than is popularly supposed. Along the walks, or beside the grape arbor, you may see the shining flowers of the stately white Madonna Lily; or perhars tall stems of their spiritual flowers are silhouetted against dark firs or boxwoods on either side the garden entrance. Tiger Lilies, bold and tawny, from the glossy black bulbils in the axils of their leaves have multiplied themselves into great beds among 


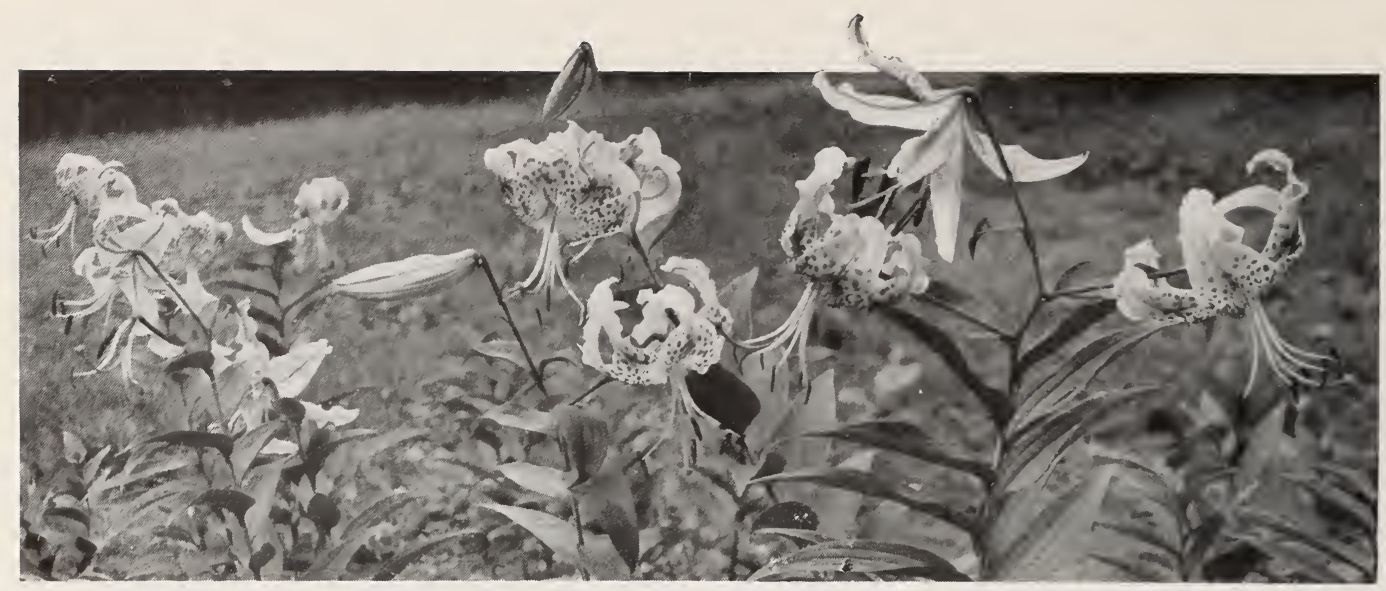

The serene, stately, faultless beauty of the Lilies. Lilium speciosum

Lilium, continued

the shrubs and lean toward you with leering, mocking grimaces. Sometimes there is a vivid, tropical picture of American Turk's-cap Lilies lifting wide crowns of ruby flowers against the mirror-like leaves of Magnolia grandiflora. The hardy garden has need of Lilies in quantity and variety to brighten its somber spots and to give a touch of elegance. Their serene, stately, faultless beauty of outline is unapproached among flowers. Among the best of newer uses for Lilies is their association with broadleaved evergreens, notably Rhododendrons and other members of the heath family, which require a winter mulch and a cool, drought-proof soil in summer, just as Lilies do. It is a good scheme to give Lily roots shelter and their bloom a foliage foil; good also to brighten dark evergreen masses with a succession and variety of rich flowers. Lily bulbs planted sparingly are meager in effect until they have had time to multiply. Planted in groups of a dozen or hundred they immediately claim recognition. For both beauty and permanence plant deeply in well-drained soil, giving the bulbs a cushion and cover of sand. For the larger bulbs a foot in depth is not too much. All Lilies prefer that fertilizers should be used only as winter top-dressings.

Lilium auratum. GOLDEN-BANDED JAPAN LILY. A we!l-grown Auratum Lily with stout stem lifting its dozen or so delightfully scented flowers to a height of 5 or 6 feet may well be regarded as the grandest of all hardy flowers. Its great blooms of ivory-white and gold are flecked with crimson dots, open widely and recurve their petals gracefully. Good leaves clothe the stem up to its inflorescence and a large bulb produces several flower-stems. There are showier forms with crimson bands through the petals instead of gol. den ones, but none so universally admired. Bulbs, prepaid, 25 cts. each; larger sizes, pur. chaser paying transportation, $25 \mathrm{cts}$. and $35 \mathrm{cts}$. each.

L. canadense. Wild Yellow LILY. This American species is perhaps our best vivid-flowered, pell-shaped Lily. A distinguished horticulturist has said of it that tinctly American as the Cardinal Flower and the pink Lady's-Slipper. "Something it has of the wildness, the suppleness and charm of cool leafy places, -in its polished wand, its fluttering leaf-whorls, its inimitable grace. With what life and fire it rises from beds of green Onocleas!" Its flowers are dainty bells of yellow, red or orange, with numcrous darker spots, swinging from stems 2 to 5 fect high. A good species for naturalizing, as it grows well even in boggy places. Bulbs, prepaid, I5 cts, each; larger sizes,
Lilium canadense. continued

purchaser paying transportation, $15 \mathrm{cts}$. and $25 \mathrm{cts}$. each.

L. candidum. Madonna Lily. The fine old Annunciation Lily, with tall stems of sweet white flowers in June. One of the most permanent garden Lilies, and, after centuries of culture, still one of the best. Its snowy bell-shaped blooms are 4 to 5 inches long, very fragrant, and average 8 to to in clusters on stems 3 to 4 feet high. The Lily of old paintings and poetical myths. Bulbs, prepaid, 25 cts. each; larger sizes, purchaser paying transportation, $25 \mathrm{cts}$. and $35 \mathrm{cts}$. each.

L. carolinianum. CAROL.rNA LILY. A graceful native, with gay flowers of intense orange-red, purple-spotted on the strongly reflexed petals, and nodding from stems 2 to 3 feet high. Quite variable in color, height. and number of blooms to the stem. Bulbs, prepaid, 25 cts. each; larger sizes, purchaser paying transportation, 25 cts. and $35 \mathrm{cts}$. each.

L. elegans ( $L$. umbellatum). JAPANESE ERECT LILY. The erect, cup-shaped flowers of this Lily are ustually self-colored in some brilliant shade of yellow, orange or red. The stems are I or 2 feet high, I- to 5flowered, and the lilies measure 5 or 6 inches across. This is perhaps our most useful garden Lily for giving in a short time, rich, solid masses of color, as it thrives in any ordinary border and multiplies at a surprising rate, asking only for fairly good soil, plenty of room and full sunshine. Bulbs, prepaid, $25 \mathrm{cts}$. each; larger sizes, purchaser paying transportation, $25 \mathrm{cts}$. and 35 cts. each.

L. speciosum. Japanese Pink Lily. This species and its varieties have great individuality in manner of growth and structure of flowers. The latter are delicately fragrant, nodding, recurved, white more or less suffused with pink or rose and brightly flecked with red; the throat of the flower has a glistening corona-like fringe of white. The stems grow 2 to 4 feet high and carry several to many blooms. Less showy than the Auratum Lily, lut more permanent, and our most satisfactory pink-and-white Lily of the Turk's cap type. Bulbs, prepaid, 25 cts. each; larger sizes, purchaser paying transportation, 25 cts. and $35 \mathrm{cts}$. each.

L. superbum. A IIERICA TURK's-CAP LILY. In deep rich soil this Lily grows from 8 to in feet high, carrying a brilliant crown of 30 or more-on one stem 57 were counted-recurved, orange-red blossoms, spotted with scarlet. The tallest of our native Lilies, with the greatest number of flowers to the stem, and very permanent in 


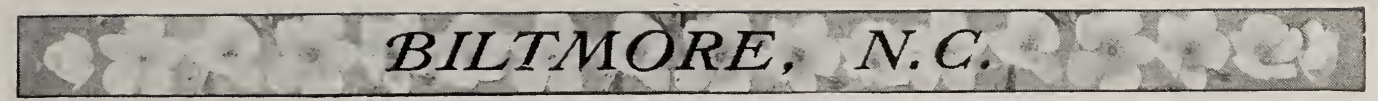

Lilium superbum, continued

character, though so variable in color, height, etc. It is easy to establish, growing even in wet soils, and nothing could be finer for grouping among Rhododendrons, or along tall borders. The texture of the flowers is such that they last longer than those of most other sorts. Bulbs, prepaid, $25 \mathrm{cts}$. each ; larger sizes, purchaser paying transportation, $25 \mathrm{cts}$. and $35 \mathrm{c}$. each.

L. tigrinum splendens. TIGER LILI. Although one of the most widely distributed species, this fine old Lily is never common when well grown. Its odd Chinese color and pronounced spots show best when the blossoms are seen in masses. The dark leaves that clothe its stem are superlatively glossy, and the nodding, black-spotted, orange flowers are picturesquely showy. The splendens strain is extra-robust, permanent and free-flowering. 3 to 5 feet. Bulbs, prepaid, 15 cts. each ; larger sizes, purchaser paying transportation, $15 \mathrm{cts}$. and 25 cts. each.

L. tigrinum flore pleno. Double Tiger Lily. Similar to the type, but has showier, more durable flowers, and an excess number of petals. Bulbs, prepaid, I5 cts. each; larger sizes, purchaser paying transportation, I5 cts. and 25 cts. each.

SPECIAL OFFER. A collection of six Lilies, no two alike, our selection of varieties, strong bulbs, prepaid $\$ 1$; larger sizes, purchaser paying transportation, $\$ 1$ and $\$ 1.50$.

\section{Linum}

Linum perenne. PerenNial Flax. An unusually attractive little plant with small, bluish green leaves and many slender stems tipped with several widely opened, dainty flowers of azure-blue or white. It grows from I2 to 18 inches high and blooms so constantly through summer as to make it of distinct value for borders and rockeries. Strong plants, prepaid, I5 cts. each; larger plants, purchaser paying transportation, I5 cts. and 25 cts. each.

\section{Liriope}

Liriope graminifolia (Ophiopogon spicatus). PURPLE SNAKEBEARD. An odd and pretty plant, with grass-like leaves growing in dense tufts from which spring one or more fine spikes of many small lavender or violetpurple flowers. Although ordinarily grown as a greenhouse plant this has withstood a temperature several degrees below zero here in our nursery and we recommend it as a dainty acquisition to the herbaceous border. Strong plants, prepaid, I5 cts. each; larger sizes, purchaser paying transportation, $15 \mathrm{cts}$. and $25 \mathrm{cts}$. ea.

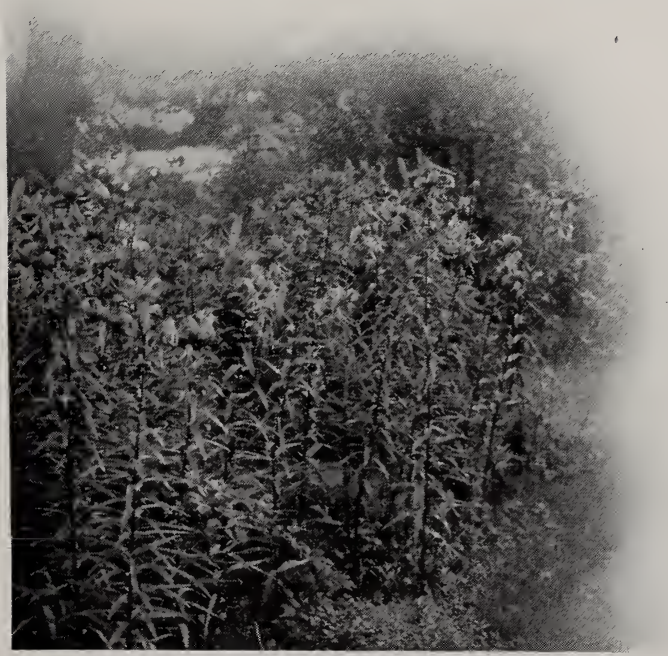

Bed of Tiger Lilies

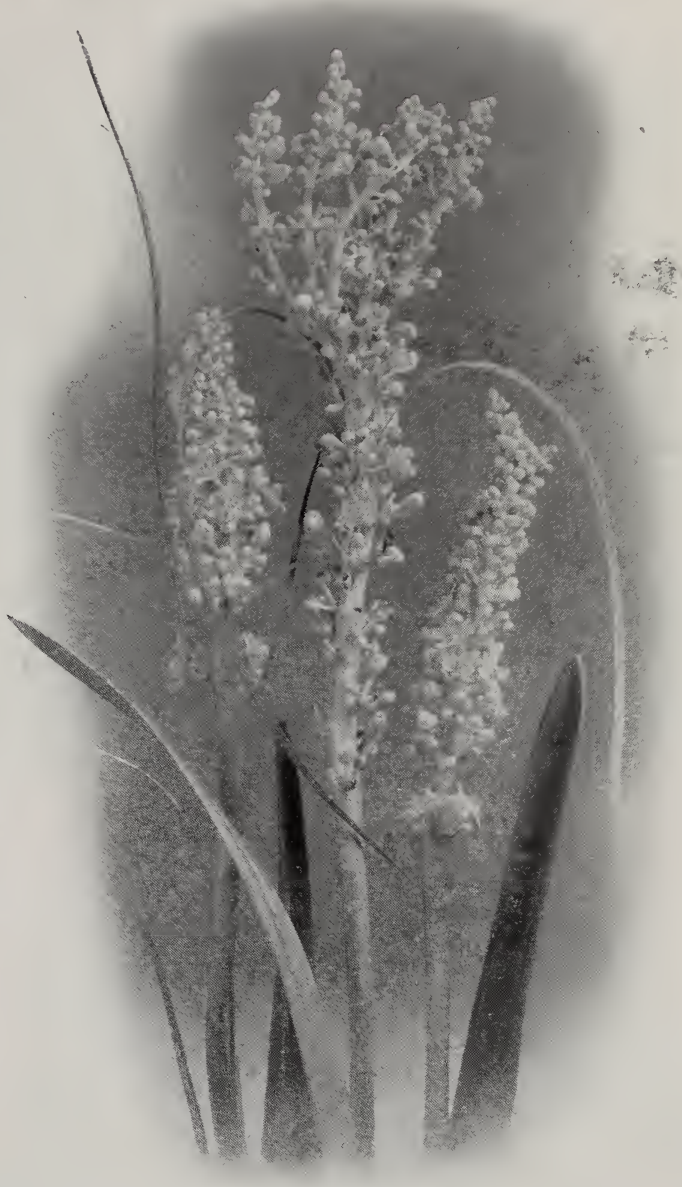

Liriope graminifolia

\section{Lobelia}

Lobelia cardinalis. CARDINAL FlOWER. This glowing flower-prelate is our most vividly colored native perennial. In a wild state it loves the haunts of the ferns and to blazon with its red banners cold bogs and ditch banks. Its tall spikes of bloom are very striking and well worth the little trouble required to establish a colony of the plants. A good clump will send up from 1o to I5 tall spikes of flashing, velvety scarlet flowers, the lower buds of which open first, so that the glowing color burns like a torch toward the top. Amid the lush green of bog and water plants their effect is meteoric. When grown outside the bog garden they like a deep, moist loam and a mulch about their roots in summer. Stems 2 to 3 feet high. Strong plants, prepaid, 15 cts. each; larger plants, purchaser paying transportation, I5 cts. and 25 cts. each.

\section{Lupinus}

Lupinus polyphyllus. LUPINE. The blue flowers of this Lupin suggest those of the Wistaria, but appear in handsome, upright spikes some time in June. The plants are robust, easily grown in any soil that does not contain lime, and are lavish of their flowers. The stems are stout and erect, 2 to 5 feet high, with leaves in distinct whorls. Gives fine border masses of blue. Strong plants, prepaid, I5 cts. each; larger sizes, purchaser paying transportation, $15 \mathrm{cts}$. and $25 \mathrm{cts}$. each. 


\section{CIN BILTMORE NURSERY ENE}

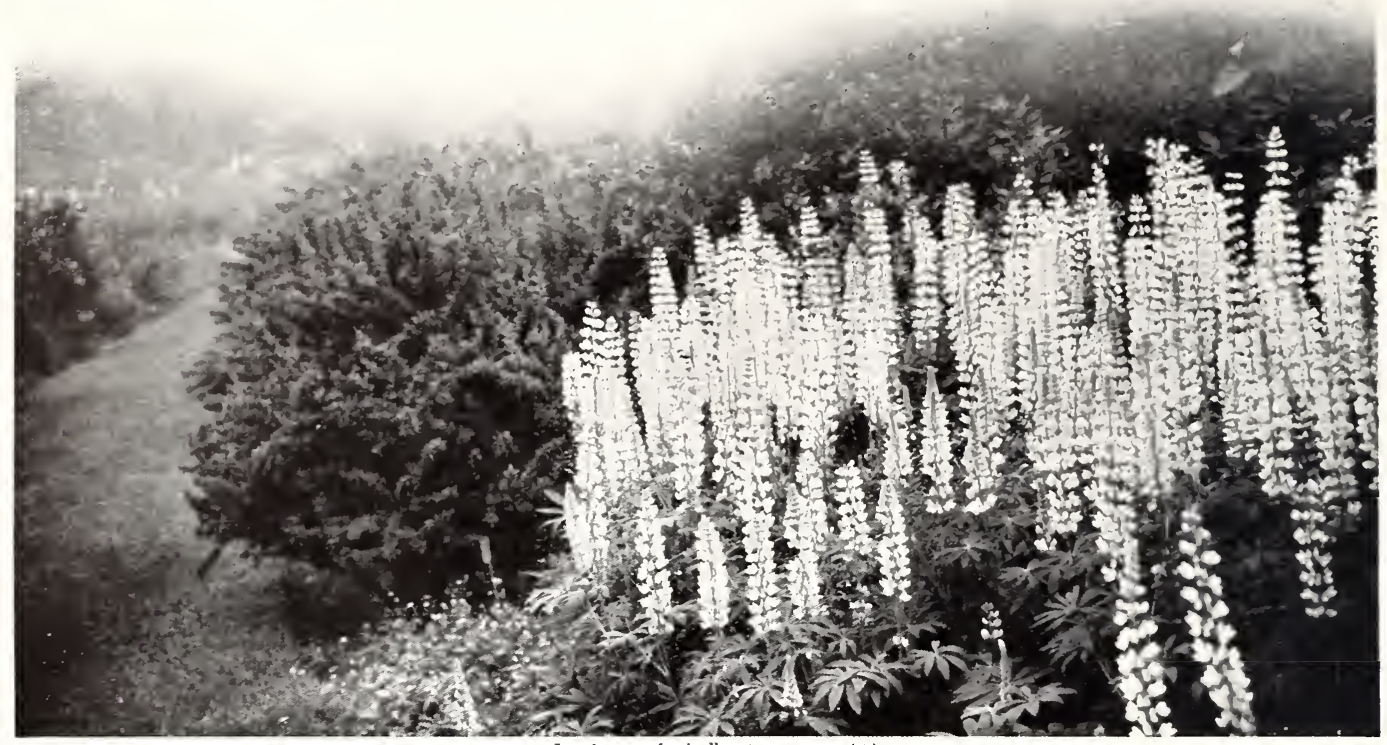

Lupinus polyphyllus (see page 41)

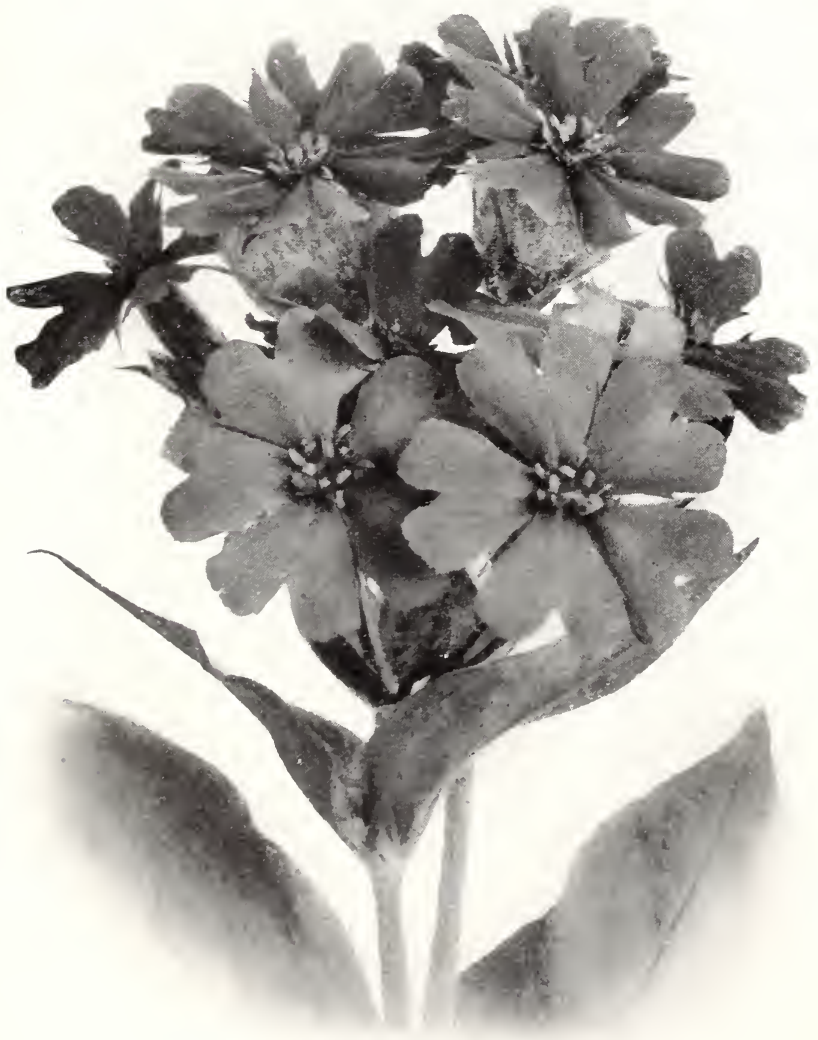

Lychnis haageana
Lychnis - The Lamp Flowers

Old time gardens owed much of their gaiety to these plants, some species of which are next to the Cardinal Flower in brilliancy. All are good border and rockery plants for sunny situations and add a brilliant touch to the garden all summer.

Lychnis chalcedonica. MALTESE Cross. LOXDON PRIDE. Through July and August this tall plant's many clusters of small flowers glow with the most vivid scarlet of the garden. 2 to 3 feet.

L. hageana. SCARlet Maltese Cross. Lowergrowing, with larger flowers from vermilion-scarlet to crimson in May and June. 6 inches to I foot.

L. viscaria splendens. Geritax CatchFly. The pretty rose-pink blossoms are pleasantly fragrant and borne on long spikes in summer. I5 inches.

Any of the above, strong plants, prepaid, $15 \mathrm{cts}$. ea.; larger sizes, purchaser paying transportation, $15 \mathrm{cts}$ and $25 \mathrm{cts}$. each.

\section{Lysimachia}

Lysimachia clethroides. Loosestrife. The long, dense, recurved stems of this handsome plant are closely set with delicate white flowers resembling those of the Clethra. They are abundant in summer and valuable for cutting. A robust, showy border species, with leafy stems 2 to 3 feet high. Strong plants, prepaid, I5c. ea.; larger sizes, purchaser paring transportation, $15 \mathrm{cts}$. and $25 \mathrm{cts}$. each.

L. nummularia. MoNerwort. One of the best creepers for carpeting the ground in moist, shaded places where grass will not grow. Its nearly round leaves clothe the stems thickly, and there is also a profuse embroidery of small golden vellow blossoms. Strong plants, prepaid, 15 cts. each; large clumps, purchaser paying transportation, $15 \mathrm{cts}$. and $25 \mathrm{cts}$. each

\section{Lythrum}

Lythrum roseum superbum. ROSY LOOSESTRIFE. Willow - like herbs with long spikes of bright flowers that give radiant effects in our marshes or naturalized in low places. This species

It is well when one can ordain to dwell among serene horizons and pure odors, purest and most penetrating of all, the Carnation, Lavender and Rosemary 


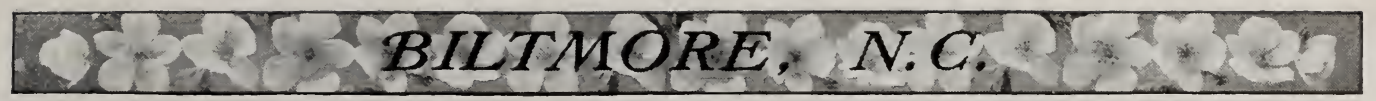

Lythrum roseum superbum, continued grows 3 or 4 feet high and has good spikes of large, bright rose-colored blossoms. It thrives well in the border and deserves room there, as it blossoms from July to September.

L. salicaria. PURPLE Loosestrife. Gives cheery masses of bright flowers when planted in boggy places or among shrubs, where it forms fine clumps. The pinkish purple flowers are in loose spikes 2 to 3 feet high.

Either of the Lythrums, strong plants, prepaid, 15 cts. each; larger sizes, purchaser paying transportation, $15 \mathrm{cts}$. and $25 \mathrm{cts}$. each.

\section{Marshallia}

Marshallia grandiflora. LARGE-FLOWERED MARSHALLIA. The Marshallias have pretty rose-purple flower-heads similar to those of the Scabious, to which a curious effect is given by the numerous blue anthers. The stems grow a foot or more in height and the leaves are distinctly veined; the blossoms appear in early summer. This fine species is a meritorious novelty.

M. trinervia. BROAD-LEAVED MARSHALliA A broad-leaved species, growing about 15 inches high, of neat habit. The flower-heads are white, flushed with pink or purple and suggest a long-stemmed, large-flowered White Clover. The plant blooms freely from June to Aupust and is useful for brightening damp shaded spots.

Strong plants of either of the above, prepaid, at $25 \mathrm{cts}$. each; larger sizes, purchaser paying transportation, 25 cts. and 35 cts. each.

\section{Mentha}

Some species of the mint family are easily naturalized in low, damp spots about the grounds, where they exhale a quaint, spicy fragrance when brushed in passing by and are always ready for mint sauces.

Mentha piperita. Peppermint. The dark, leafy stems grow from I to 3 feet in height and terminate in thick terminal spikes of purplish white flowers.

M. spicata. SPEARMINT. A familiar plant in the older gardens, where it grows I to 2 feet high and bears its whorled flowers in narrow spikes.

Either of the above Mints, strong plants, prepaid, 15 cts. each ; larger sizes, purchaser paying transportation, $15 \mathrm{cts}$. and $25 \mathrm{cts}$. each.

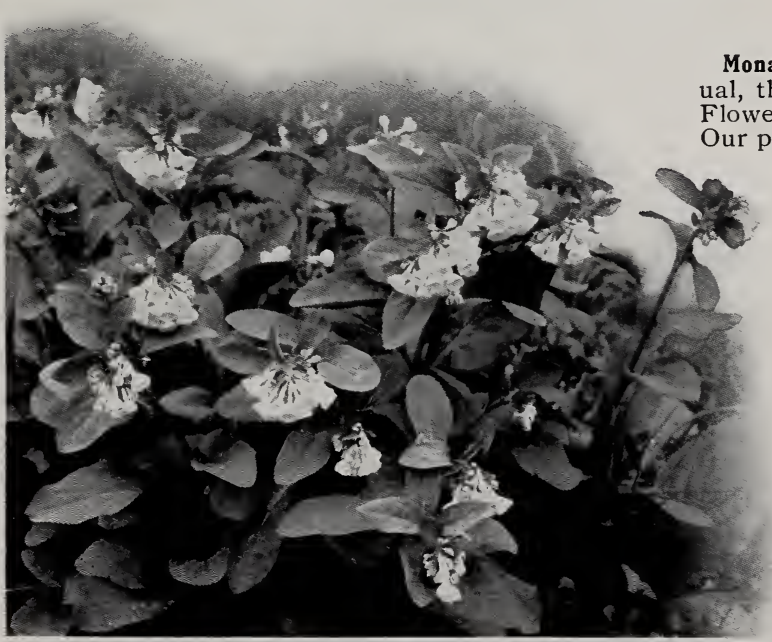

Mertensia virginica

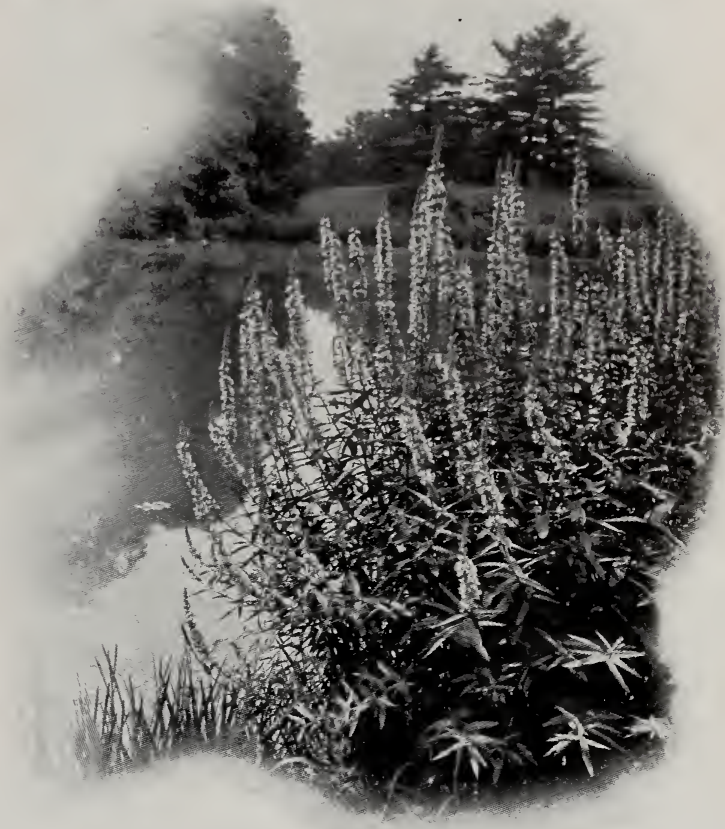

Lythrum roseum superbum

\section{Mertensia}

Mertensia virginica. VIRGINIAN Cowslip. BLUE BELLS. One of the earliest and loveliest of spring flowers, abounding along stream banks and in moist meadows through April and May. Its drooping bells of porcelain-blue are frequently shaded with lilac, and in size and shape suggest those of the true Cowslip. In exposed positions and deep, moist soils the rich dark purple of the early leaves is almost as beautiful as the flowers. The uncurling racemes show pinkish buds and straighten, as the flowers expand, to a height of I or 2 feet. The so-called bells are really trumpetshaped, but usually drooping, and about an inch long, in graceful clusters. Also called Lungwort. Delights in a moist, loamy soil. Strong plants, prepaid, 15 cts. each; larger sizes, purchaser paying transportation, I5 cts. and $25 \mathrm{cts}$. each.

\section{Monarda}

Monarda didyma. BeE BALM. Oswego Tea. As us, the old Indian name of O-gee-chee, "Flaming ower," is much the most appropriate and poetic. Our popular one of Oswego Tea probably came from the medicinal use of it by that tribe. This is the showiest of all the larger-flowered Labiates and the finest plant of its genus. Its bold, bright scarlet flower-heads are two or more inches across on leafy, angled stems about 3 feet high, and when massed for distant effects against a dark backg ound, give bright, semitropic garden pictures in late summer. Both bees and humming-birds love them and they continue bright for many weeks. The leaves have a pleasant mintlike odor. Strong plants, prepaid, is cts. each; larger sizes, purchaser paying transportation, I 5 cts. and 25 cts. each.

Last year you sent me amongst other plants some Alpine Rhododendrons (I think that was the name), which have done so well here, and so much better than the Laurel, that I wish you would send me a dozen more of those plants. All the Biltmore things are doing well. WiNSTON CHURCHILl, Harlakenden House, Cornish, N. H., April II, I908. 


\section{QT BILTMORE NURSERY XNE?}

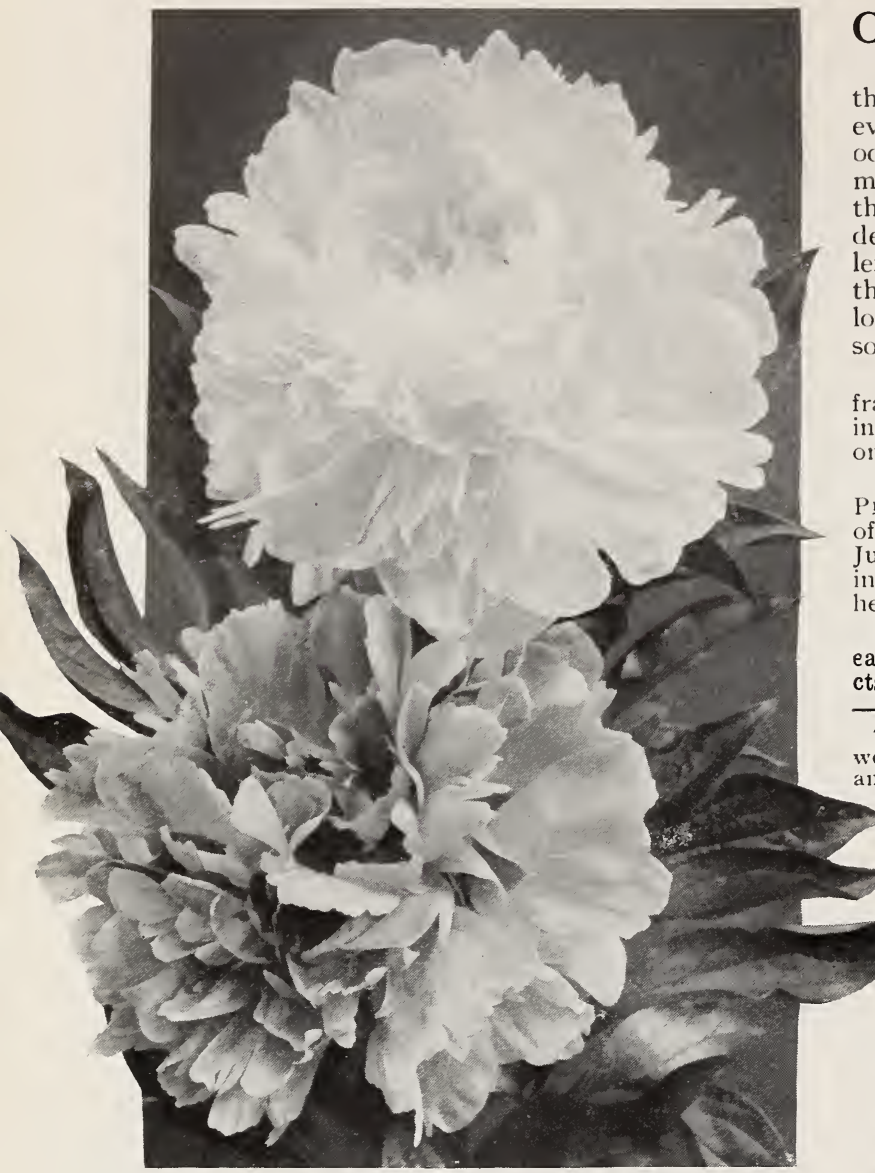

Enothera - Evening Primroses

The half-trailing Evening Primroses that open their great, luminous yellow flowers in the dusk of evening, attracting night-moths and wafting sweet odors abroad, add no little to the spell of enchantment lying over a moonlit garden. So far, however, they have not been widely used in American gardens, though commuters and others who have leisure for gardens only in the evenings, would find them most enjoyable. The species below are sunloving, robust and very permanent in dry, gravelly soils.

OEnothera fraseri. FRASER's Sundrops. Handsome, fragrant and free-blooming in midsummer when grown in good soil. The flowers are a beautiful rich yeliow, on $I^{1 / 2}$ - to 2 -foot stems.

OE. missouriensis. LARGE-FLOWERED EVENING PRIMROSE. A superb trailer, with enormous flowers of soft, sulphur-yellow, sometimes 5 inches across, in June and July. They open more widely in the evening and are quite fragrant. Rarely more than a foot in height, but very robust, growing even in stiff clay.

Either of the above, strong plants, prepaid, $15 \mathrm{cts}$. each; larger sizes, purchaser paying transportation, 15 cts. and 25 cts. each.

Types of large-flowering Peonies (see page 45)

\section{Myosotis}

Myosotis palustris. TRUE FORGET-ME-NOT. One of the cheeriest and most charming of our low, blue-flowered perennials. Its pretty, dainty sprays of small, soft blue blossoms, with smiling yellow eyes, are loved, familiar feature of old-fashioned gardens, where, in moist, shaded places, the plants form dense mats of bright green, sprinkled plentifully through May and June with the blue and gold of their flowers. Strong plants, prepaid, ${ }_{5} \mathrm{cts}$. each: larger sizes, purchaser paying transportation, $15 \mathrm{cts}$. and $25 \mathrm{cts}$. each.

\section{Nierembergia}

Nierembergia rivularis. White CuP. This choicest of the Nierembergias spreads a thick mat of creeping stems about 6 inches in depth over which to display its white flower-cups. These are large and beautiful, $1 \frac{1}{2}$ to 2 inches across, and creamy white, sometimes faintly flushed with pink or blue, and blotched with yellow in the throat. The growth is most luxuriant in moist, semi-shaded spots, but the plant occasionally forms fine colonies on dry banks, or even in rockeries, blooming from June to September. This use of it is strongly recommended on account of its continuous bloom. Strong plants, prepaid, $15 \mathrm{cts}$. each; larger sizes, purchaser paying trans portation, $15 \mathrm{cts}$. and $25 \mathrm{cts}$. each.

The plants came in fine condition. They were put out at once and are doing well. Thanks for the extra. Your plants are excellent size and look stocky and sure of good results. Very truly yours, Mrs. C. W. SAPPELL, Frankfort Ky.

The plants ordered from you were received in fine condition and most of them planted, and it can be neither your fault nor mine if they do not prosper. Yours truly, ANNIES. BEAN, San Jose, Cal., March 8,1909 .
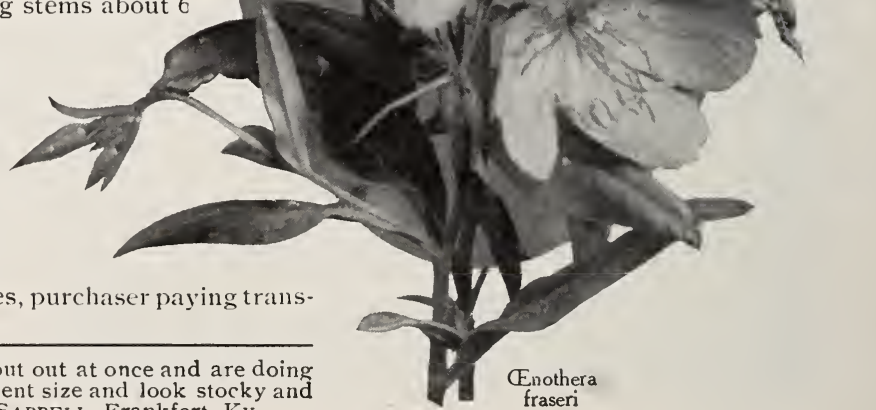


\section{BILTMORE, N.C. DT NO?}

\section{Opuntia}

0puntia vulgaris. PrICKLY PEAR. Hardy CaCtus. This picturesque, hardy old plant is a great favorite for rockeries, especially with fanciers of cactaceous or succulent plants who have not space for a good collecare prostrate and resemble round, flattened green cushions glinting with sharp spines. In late spring and summer, large yellow flowers 2 inches across further decorate their edges and are followed by red pear-shaped fruits about an inch in diameter. Mr. William Falconer recommends their use on bleak, exposed banks and rocky knolls in connection with Yuccas, and finds them perfectly hardy where so used in Schenley Park. Pittsburgh. Given a porous, welldrained soil and sunny exposure, they should prove hardy even in our more northern states. Strong plants, prepaid, I5 cts. each; larger sizes, purchaser paying transportation, $15 \mathrm{cts}$. and $25 \mathrm{cts}$. each.

\section{Pachysandra}

Pachysandra procumbens. Alleghary Spurge. The evergreen creeping Spurges go far toward solving the problem of finding a low, dense ground-cover that is beautiful even in winter. The matted rootstocks of the Alleghany Spurge spread rapidly and in all except severe climates its oddly mottled green leaves are persistent through winter. Quaint little spikes of white or lilac-tinted flowers are produced from the base of the stems with the earliest breath of spring, attracting multitudes of bees.

P. terminalis, JAPANESE SPURge. Even in our coldstretches closely with its distinctively shaped, thick, glossy, light green leaves. In this species the white flowers appear in terminal spikes, usually in May. They are followed by white, waxen berries somewhat smaller than a cranberry. This is the hardier species and the one most often cultivated. Both combine beautifully with our evergreen Ferns for massing in moist, half-shaded places, as above a spring of running water.

Price of either of the above, strong plants, prepaid, 15 cts. each; larger plants, purchaser paying transportation, 15 cts. and 25 cts. each. tion of tender sorts. Its thick and fleshy jointed stems est states this is a true evergreen, carpeting wide

\section{Paeonia $\cdot$ The Peonies, or Pineys}

After many years of comparative neglect the Peony has again come into its own. The recent enthusiasm for all varieties has made prominent their claim to entire hardiness, vigor, permanence and wonderful brilliancy of bloom. A good clump is easily established and each succeeding year adds to its size and beauty. The Peony has the largest double flowers of all the hardy perennials, while some of its single types are as graceful and artistic as Anemones, and not unlike them. The newer double varieties show the hybridizer's skill in delicately tinted, cupped blooms, enormous in size and almost with the finish of fine Roses. Peonies thrive best in rich, moist loam, well-enriched and fully exposed to the sun. In planting, the crowns should be set two or three inches below the surface of the ground; too deep planting is sometimes a cause of failure to bloom. An annual top-dressing of good compost will help to establish the roots and keep them vigorous.

Double-flowered forms of Chinese Peonies Achille. Very delicate pink or flesh-color; nearly white. Agida. A superb dark glowing red.

Alba plena. A fine pure white.

Alexandrina. Beautiful lilac-rose.

Ambrose Verschaffelt. Wine-red, with lighter tips. Andre Lauries. Rich velvety red; late-flowering.

Anemoneflora. Dark crimson, with center of small petals. Bicolor. Light pink with a cream-colored center. Buycchi. Delicate pink, changing to white. Comte Neipperg. Brilliant reddish crimson.

Delachei. Deep crimson; late-flowering.

Duc de Cazes. Dark rose, shading to salmon.

Duchesse de Nemours. Pure white; extra large and fine. One of the very best varieties.

Duchesse d'0rleans. Dark rose, with shades of salmon in the center.

Duke of Wellington. Yellowish white; very soft.

Edulis superba. Rose, tinted with violet.

Festiva alba. Pure white; large and fine.

Festiva maxima. White, with the central petals flaked with red. A superb variety. Formosa rosea. Light rose, paler in the center.

Humei. Rich rose; late.

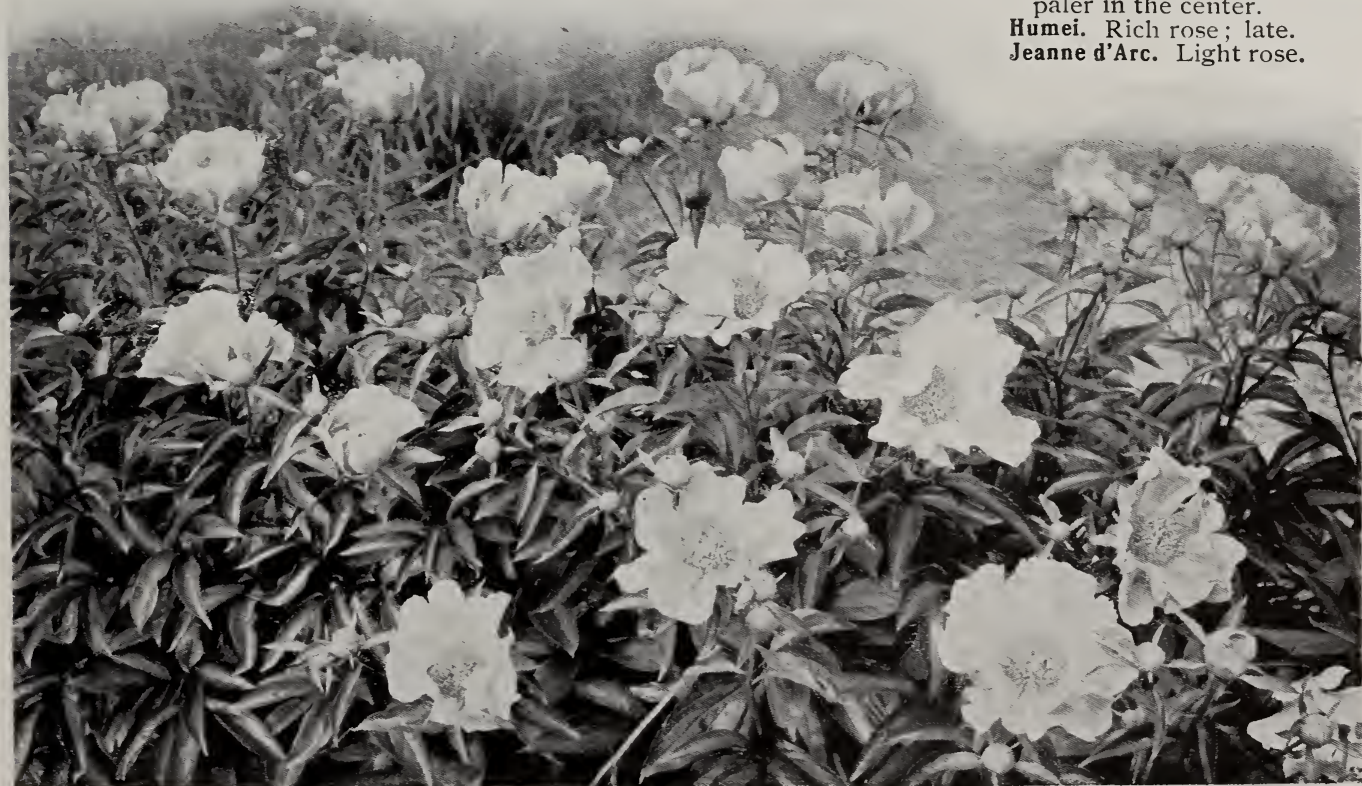

A bed of Single-flowered Chinese Peonies (see page 46) 

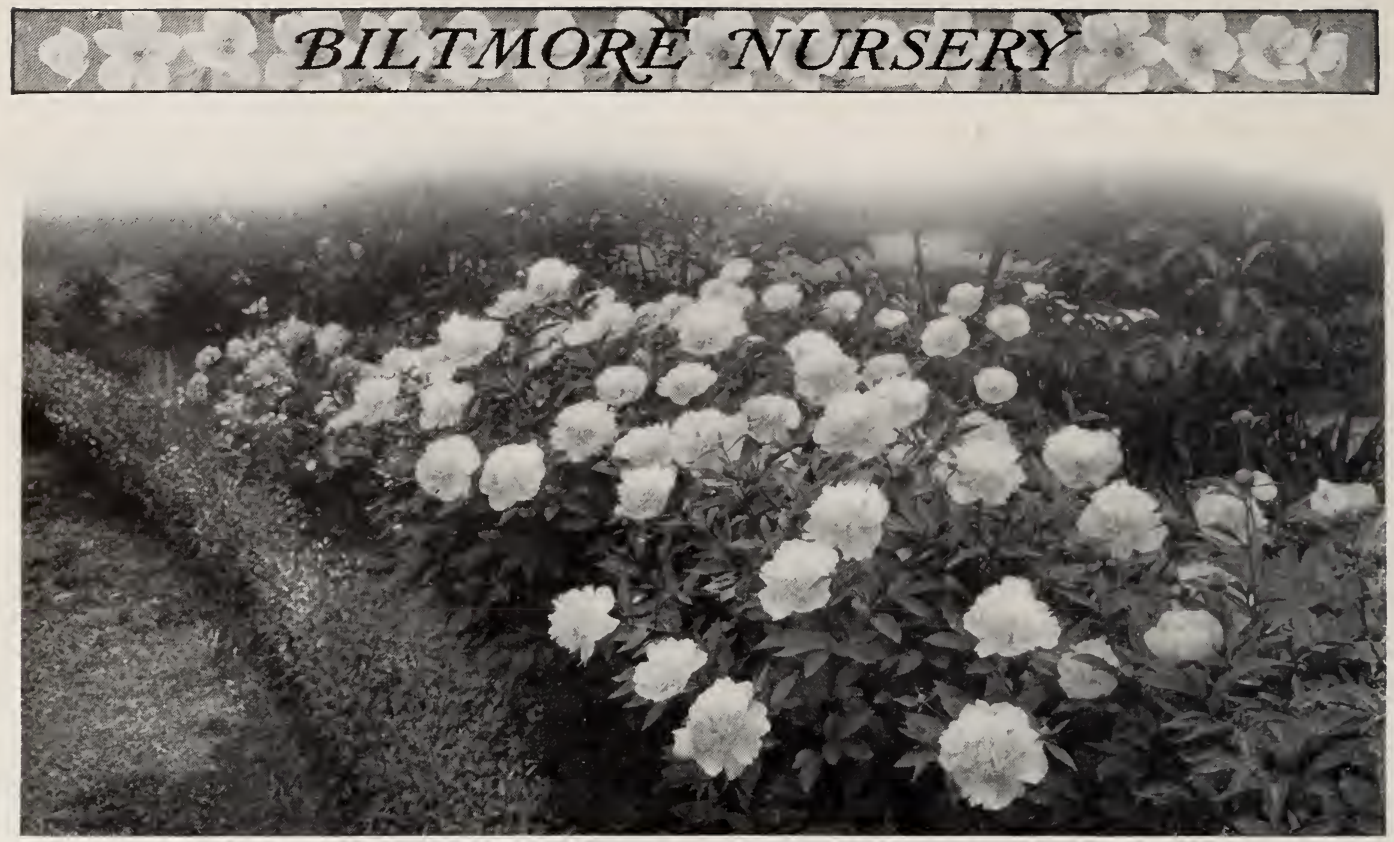

The Double Peonies make a gorgeous show in early June

Double Peonies, continued

Lamartine. Beautiful violet-rose. One of the largest.

L'Esperance. Pink, striped with carmine.

Louis Van Houtte. Bright satiny crimson.

Marshall Vaillant. Violet-purple ; late-flowering.

Ne Plus Ultra. Delicate shell-pink.

Paganini. Violet-rose with a sulphur-yellow center.

Poiteau. Flesh-white.

Princess Mathilde. Violet-rose.

Queen Victoria. White; very free-flowering.

Reine des Fleurs. Fine rosy pink with a salmon center.

Reevesi. Large, light pink.

Rosea elegans. Soft rose, with light center.

Sydonie. Delicate rose.

Whittleyi. A fine early-flowering white variety.

Any of the above named varieties of Chinese

Peonies, strong plants, prepaid, $35 \mathrm{cts}$. each;

larger sizes, purchaser paying transportation,

$35 \mathrm{cts}$. and $50 \mathrm{cts}$. each.

We also offer an assortment of doubleflowered Chinese Peonies, strong plants, in various shades of color, our selection, prepaid, 25 cts. each; larger sizes, purchaser paying transportation, $25 \mathrm{cts}$. and $35 \mathrm{cts}$. each.

Single-flowered Chinese Peonies Abidan. Purple.

Abora. Rosy lilac.

Abyla. Carmine.

Iphis. Maroon. Josephine. Dark red.

Libon. Rose-pink.

Gabreta. Dark crimson. The Bride. White.

Any of the above named varieties of Singleflowered Chinese Peonies, strong plants, prepaid, $50 \mathrm{cts}$. each; larger sizes, purchaser paying transportation, $50 \mathrm{cts}$. and $65 \mathrm{cts}$. each.

We also offer an assortment of Single-flowered Chinese Peonies, in various shades, our selection, strong plants, prepaid, $35 \mathrm{cts}$. each larger sizes, purchaser paying transportation $25 \mathrm{cts}$. and $50 \mathrm{cts}$. each.

Double-flowered forms of Pæonia officinalis, the old-time Peony

Blossoming ten days or a fortnight earlier than the forms of Chinese Peonies. These are the old-fashioned Peonies with very full, double, fragrant flowers.

Alba. Blush-white. Rosea. Bright rosy pink. Rubra. Glowing crimson; the earliest of all

Any of the above, strong plants, prepaid, $35 \mathrm{cts}$. each; larger sizes, purchaser paying transportation, $35 \mathrm{cts}$. and $50 \mathrm{cts}$. each.
The Cut-leaved Peony.

Paeonia tenuifolia. Flowers single or double, rich scarlet. Leaves deeply cut into numerous linear lacelike segments. The single species resemble Tulips or large Japanese Anemones, and make a handsome show with their broad, silky petals and brilliant golden stamens. Strong plants, prepaid, $35 \mathrm{cts}$. each; larger sizes, purchaser paying transportation, $35 \mathrm{cts}$. and $50 \mathrm{cts}$. each.

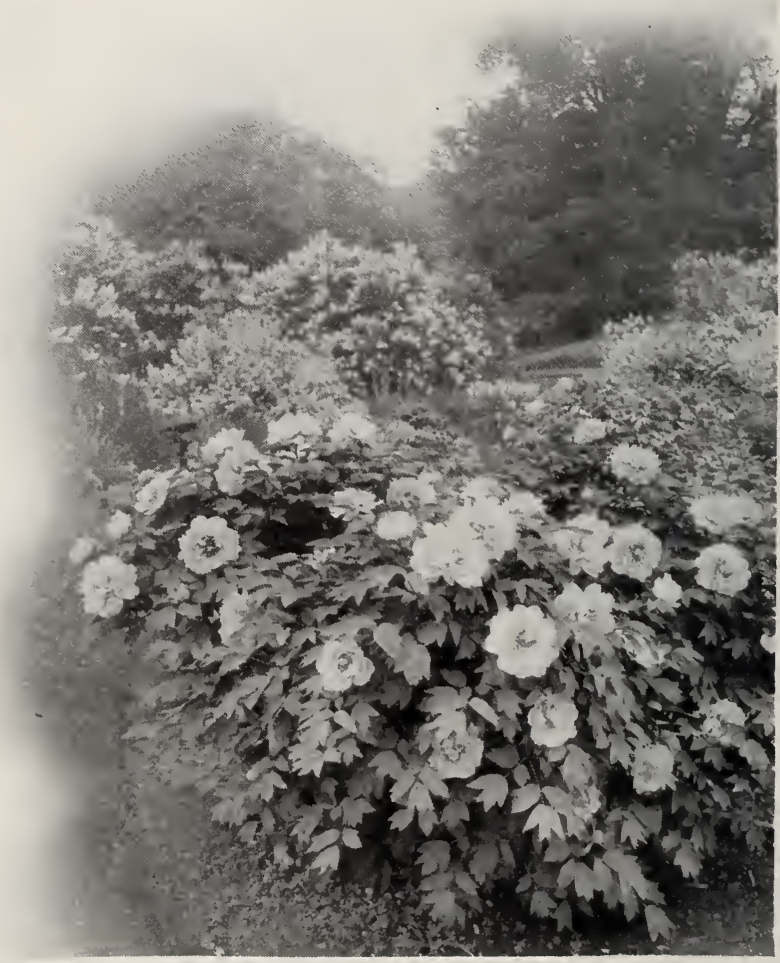

Tree Peony (see page 47) 


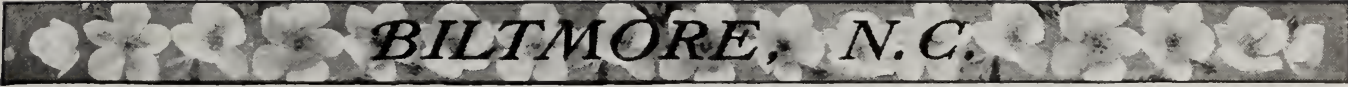

\section{Tree Peonies - Pæonia moutan}

The shrubby stems of the Tree Peonies are not killed back in winter like those of the Chinese herbaceous section. In time they grow from 3 to 6 feet high, and there are traditions of a Tree Peony that held 500 great flowers at a time. These flowers are distinct from those of the herbaceous section, open about two weeks earlier, and a re remarkably beautiful. The list appended contains some of the most desirable forms in cultivation.

Comte de Plandres. Dark rose.

Elizabeth. Rosy red.

Gloire des Belgiques. Rose.

Guillaume Tell. White.

Regina belgica. Rose.

Semperflorens alba. White.

Van Houttei. Lilac-rose.

Any of the above named varieties of Tree Peonies, strong plants, prepaid, $\$ 1$ each; larger sizes, purchaser paying transportation, $\$ 1$ and $\$ 1.25$ each.

\section{Papaver}

Papaver orientale. ORIEnTAL POPPY. The scarlet flame of the great Oriental Poppies dominates all other colors in their blooming season. They are not for mixed borders, but glow like beacons when isolated groups of them are seen from a distance against a green background. At the bottom of its great silken 6to 8-inch cup, the Oriental Poppy wears its insignia of rank, a Maltese cross of purple-black. Its stems are 3 to 4 feet tall and its large, rich, deeply cut leaves are silvery with pubescence. The popular name is well given, for every suggestion of the flower is Oriental, from its color to its gorgeous effects. Strong plants, prepaid, I5 cts. each; larger sizes, purchaser paying transportation, I5 cts. and $25 \mathrm{cts}$. each.

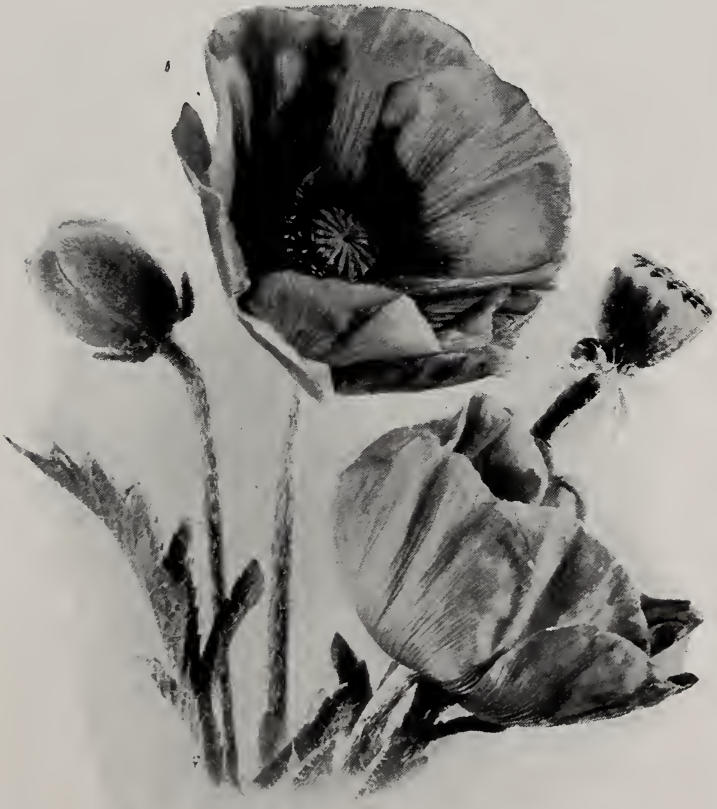

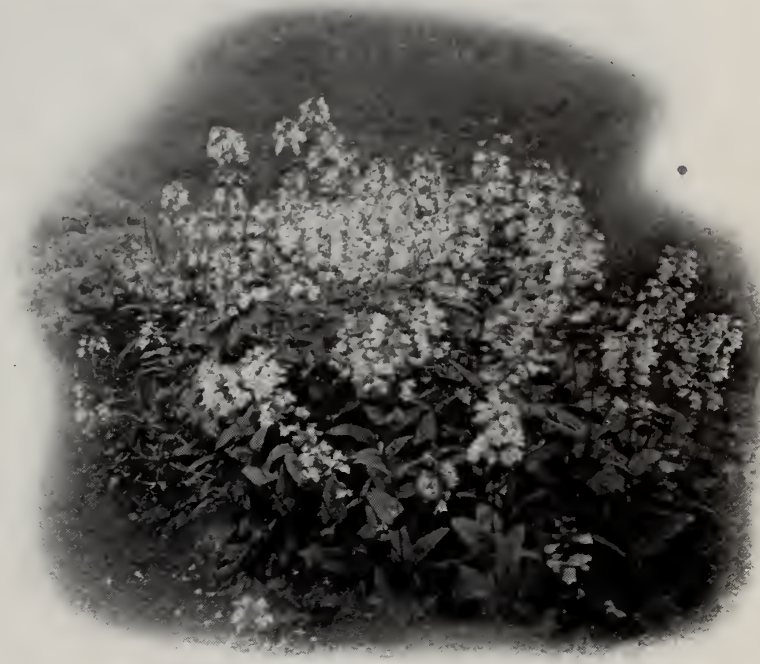

Pentstemon digitalis

\section{Pentstemon}

The Beard-Tongues have a spirited grace all their own and many good colors from which to choose in grouping a border. Their odd, long-tubular and sometimes two-lipped blossoms are grouped in leafy clusters and keep the space allotted to them rife with color all through July and August. A sandy, well-drained soil, somewhat moist in summer and containing some leaf-mold, suits them to perfection. Though usually hardy they frequently suffer more from too much moisture in winter than from frost. A winter mulch is beneficial in severe climates. The species below are the hardiest and handsomest.

Pentstemon barbatus torreyi. SCARLET BEARD-TONGUE. A good mass of this plant is very bright in effect from the pure and brilliant scarlet of its 2-inch long tubular flowers. They are like miniature scarlet Foxgloves loosely strung on slender, nodding stems, the length of which is good for cutting. Grows 3 to 4 feet high and blooms from June to August.

P. digitalis. Foxglove Beard-Tongue. The pretty lilac blossoms of this species have deep purple throats and are borne in fine spikes on stems 2 to 3 feet high in midsummer.

Any of the above, strong plants, prepaid, 15 cts. each ; larger sizes, purchaser paying transportation, $15 \mathrm{cts}$. and 25 cts. each.

\section{Phlox - The Perennial Types}

Garden forms of the tall, spectacular Phloxes naturally figure prominently in American gardens, for they are distinctively American plants - the product of two or three native species. Their huge dome-shaped panicles are sometimes a foot in length and of almost every color imaginable; pure white, scarlet, salmon, pink, purple, rose and crimson. In the stately summer pageant they are worthy successors to Peonies and Poppies, filling right royally the space between these and the Chrysanthemums. The spring-blooming Phloxes, on the contrary, are low and lovely and lovable, making

Papaver orientale

Six plants of any one kind will be furnished at five times the single rate, and a dozen plants of any one kind at ten times the price for each plant 


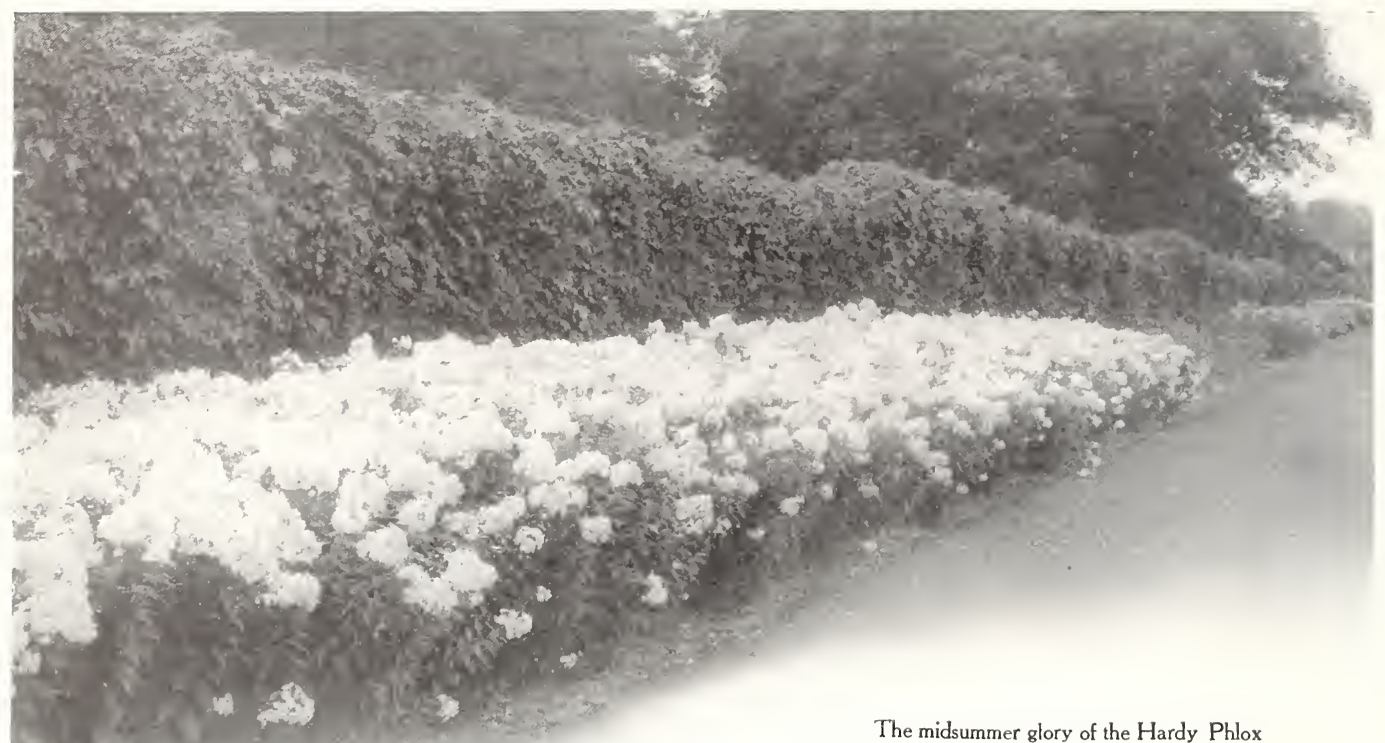

The midsummer glory of the Hardy Phlox

Phlox, continued

Phlox, continued

the same sort of an appeal to us that Pansies and Daisies do. A few of them are fragrant and all are easily grown in any sunny, well-drained soil of average fertility. The tall Phloxes give finer flowerheads in a moist fertile loam. From the species and varieties described below, by careful grouping and selection, a border planted with Phlox alone can be kept attractive all the season.

Phlox amoena. HAIRY PhLox. The pink, white or lilac blossoms of this Phlox spread cheery flakes of color in late spring, wherever we have given them leave to grow, taking up the color scheme as the Moss Pink begins to fail. It is not quite so dense in growth as the latter and is taller, from 6 to 12 inches high, and blooms longer. It is useful for dry banks or rockeries.

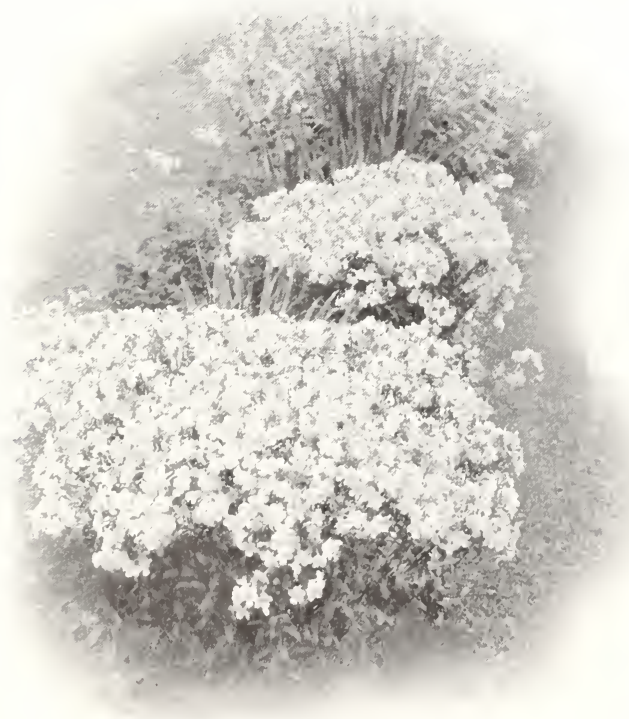

Phlox ovata
Phlox glaberrima. Shooth Phlox. A species so distinct and promising that several choice varieties of it have been disseminated. Its pink or rosy lilac flowers appear in late spring and early summer in flattened clusters, on stems I to 2 feet in height. The smooth leaves are narrowly lanceolate. The varieties described below are all distinct and desirable, blooming several weeks earlier than Phlox paniculata and its tribe, usually in May.

Indian Chief. Rosy purple, with crimson eye.

Lady Musgrove. White, each petal having a band of ruddy purple.

Nettie Stewart. Soft rose.

Perfection. White, with carmine eye.

Snowdon. Pure white.

Any of the named varieties of Phlox glaberrima, strong plants, prepaid, 25 cts. each; larger sizes, purchaser paying transportation, $25 \mathrm{cts}$. and $35 \mathrm{cts}$. each.

P. ovata. Mountain Phlox. Carolina Phlox. This handsome native of our mountains grows from I to 2 feet high and has many large, bright pink or rosy purple blossoms. The leaves are ovate, or broadly lanceolate, and rich green. It blooms in May and June and is one of the best sorts for bright effects in spring bedding. Only lately has it begun to receive the recognition it deserves.

P. paniculata. TALl GARDEN PhLOX. It is upon this splendid species that gardeners have expended most of their skill, to which it responds with wonderful readiness. The average height of the stems is now from 2 to 4 feet, and from the rosy purple color of the original species a marvelous range of tints, shades and markings has been developed. The first great bloom-heads appear in July and August; if these are cut away when faded, lighter ones follow and are gay until frost. By cutting out all the weaker stems of a good clump, those remaining can be made to produce panicles a foot in length, if well watered and fertilized. Or by pinching back some clumps in early June and a sain in July their blooming time is postponed until September. Thus botin the character of the flowers and their season are in the gardener's control. The finest flower-trusses are produced on plants 2 or 3 years old, and frequent division or transplanting is necessary in some soils. Where it continues to thrive, however, the magnificent crown of bloom given by an old plant is far more effective than the few large trusses of a younger one. WVe offer a superb collection of varieties, embracing the best forms in cultivation.

Andreas Hoffer. Pure white.

Bouquet de Fleurs. White, with deep rose ere.

Bridesmaid. White, with a large crimson eye.

Champs-Elysees. Rich purplish crimson.

Coquelicot. Scarlet, with dark carmine eye. 


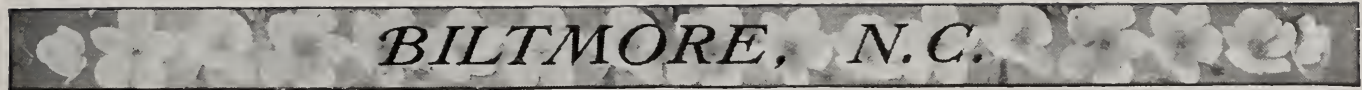

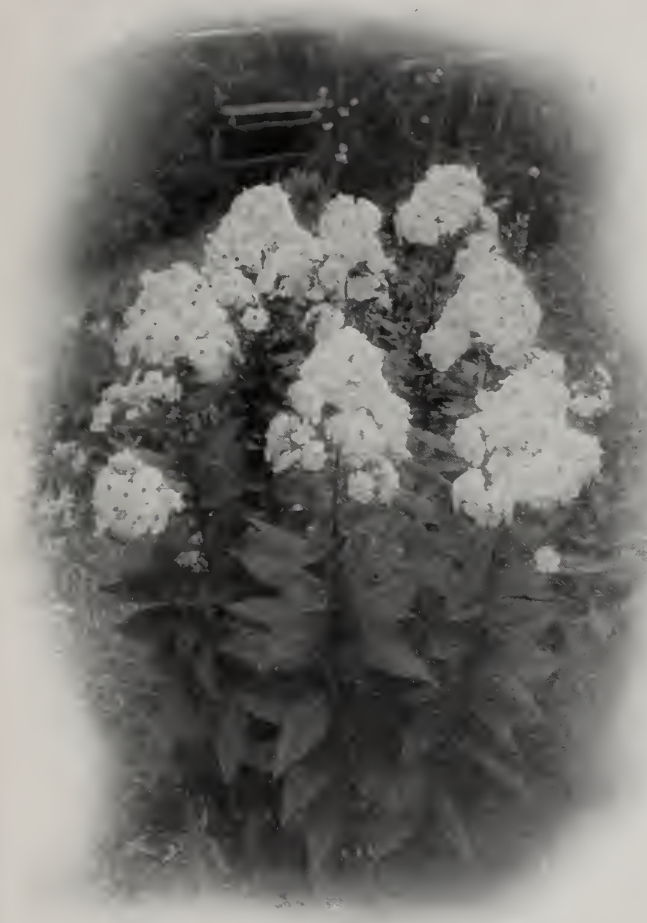

Hardy Phlox, Jeanne d’Arc

Phlox paniculata, continued

Cross of Honor. Lilac, margined with white.

Eclaireur. Purplish crimson, with bright shades toward the edge of petals.

Esclarmonde. Lilac, mottled with white; deep rose eye. Eugene Danzanvillier. Lilac, with white edge and center. Jeanne d'Arc. White; large and late-flowering.

Jocelyn. Salmon.

Jules Finger. White, with red eye.

La Fondre. Purple-crimson, with carmine center.

La Vogue. Rosy mauve, with red eye.

Lothair. Salmon, with crimson eye.

Marquis de St. Paul. Rosy salmon, with crimson eye.

M. Gladstone. Soft rose, with crimson eye.

0rnament. Rosy magenta, with crimson eye.

Pantheon. Deep rosy salmon.

P. Bonnetain. Rose, overlaid with salmon.

Prof. Schliemann. Lilac-rose, with carmine eye.

P. reptans. CREePING Phlox. This is the species which makes so beautiful our open woods in spring. The flower-color varies with soil and situation from light lilac to deep violet. The stems are from 6 to 12 inches high and droop at a graceful angle; both stems and leaves disappearing entirely after the blooming season, which begins here in April, but farther north is May and June.

P. subulata. Moss PINk. This daintiest of the Creeping Phloxes is also the most useful member of a group unequaled for garden decoration among hardy plants. Its soreading stems and narrow, moss-like leaves form thick evergreen mats that brighten in spring even before the grass, and soon are quite hidden by drifts of flowers. In autumn the plants bloom again, but not so profusely. It is one of the best plants that can be used for rockeries, wall-tops, rock ledges, dry terrace banks and gravelly hillsides, growing literally in any soil that is not either wet or deeply shaded. We offer also some garden forms distinguished by the colors of the flowers :
Atropurpurea. Rosy purple. Rosea. Bright rose.

Except where noted, any of the species or varieties of Phlox, strong plants, prepaid, 15 cts. each; larger sizes, purchaser paying transportation, $15 \mathrm{cts}$. and $25 \mathrm{cts}$. ea.

SPECIAL OFFERS. A collection of twelve named varieties of Tall Garden Phlox, no two alike, our selection, strong plants, prepaid, $\$ 1.25$; larger plants, purchaser paying transportation, $\$ 1.25$ and $\$ 2.25$.

A collection of six Dwarf Phlox, including vacieties of the Moss Pink and other forms, no two alike, our selection of varieties, strong plants, prepaid, $75 \mathrm{cts.;} \mathrm{larger}$ sizes, purchaser paying transportation, $75 \mathrm{cts}$. and $\$ 1.25$.

\section{Physostegia - Dragon Heads}

The False Dragon Heads are not new to culture, but gardeners generally are just discovering how beautiful they are when grown in large clumps and masses. A few straggling specimens rarely give a good idea of the possibilities of any flower. The Physostegias are robust in habit, soon spreading into fine masses that bloom lavishly from June until frost if prevented from seeding. They have strong, rigid, stately flower-stems 2 to 4 feet high and heavily freighted with bloom. The blossoms resemble in outline a much magnified flower of the Heather. The species below all give choice flowers for cutting.

Physostegia virginiana. FALSE DRAGON HEAD. A handsome native species that grows from I to 4 feet high and blooms all summer. The flowers are about an inch long and pale rose-pink or purple in color.

P. virginiana alba. An exceedingly pretty white-flowered form of the species just described, having all its good traits and an even more delicate beauty.

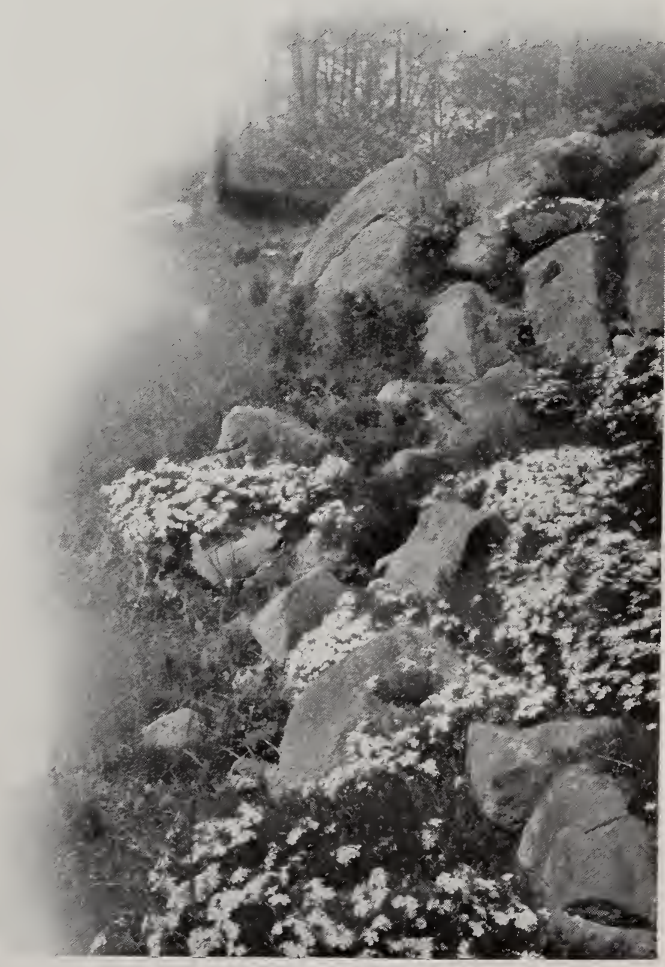

Phlox subulata 
Physostegia, continued

Physostegia virginiana speciosa. Similar to the preceding, with flowers of a soft and delicate pink.

Any of the Physostegias, strong plants, prepaid, 15 cts. each; larger sizes, purchaser paying transportation, 15 cts. and 25 cts. each.

\section{Platycodon Balloon Flower}

Platycodon grandiflorum. Chinese Bellflower. BALLOON FLOWER. A choice and extra-free flowering old-time perennial of dense habit; muchbranched, from I to 2 feet high and bearing a great blue or white flower at the tip of each branchlet. The balloon-shaped buds are almost as handsome as the star-shaped blossoms, which resemble Campanulas. A we 11. established plant has from 8 to 12 stems and keeps up a fine display of flowers for a good part of the summer, and is one of the most conspicuous and beautiful plants in the hardy garden.

P. grandiflorum mariesi. Glaucous Chinese BELLFLOWER. A lower and more compact form with stouter stems and larger flowers. The contrast of the blue or lavender blossoms with the very glaucous leaves is

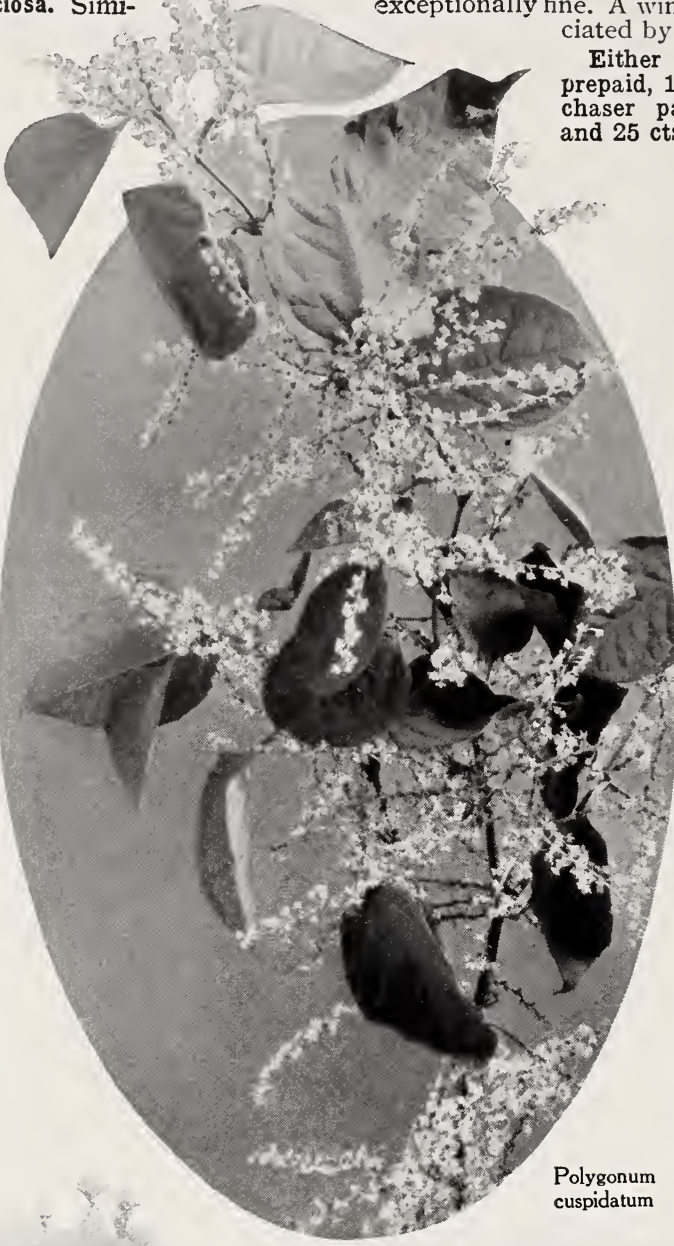

Platycodon grandiflorum mariesi, continued xceptionally fine. A winter protective mulch is appreted by both these Platycodons.

El of the above, strong plants, . and 25 cts. each.

\section{Polemonium}

Pol e moini um caeruleum. JACOB'S LADDER. A quaint old-fashioned plant of easy culture and charming individuality. Its spikes of showy blue flowers appear in late spring and early summer on stems about a foot high, above compound, deep green leaves. Fine for adding a touch of blue to the hardy garden.

P. caeruleum album. Flowers white. A useful border plant, of graceful growth and free-flowering habit.

Prices of the above, either color, strong plants, prepaid, 15 cts. each; larger sizes, purchaser paying transportation, 15 cts. and 25 cts. each.

\section{Polygonum}

Polygonum cuspidatum. Japanese Polygonum. A bold, handsome plant, 4 to 6 feet tall, with stout, clustered stems. From the axils of the leaves are borne myriads of small white flowers in a cloudlike mass of sprays, giving a soft, misty effect. Hardy and stately ; useful for giving bold masses of foliage and tropical effects. Strong plants, prepaid, I5 cts. each; larger plants, purchaser paying transportation, 15 cts. and $25 \mathrm{cts}$. each.

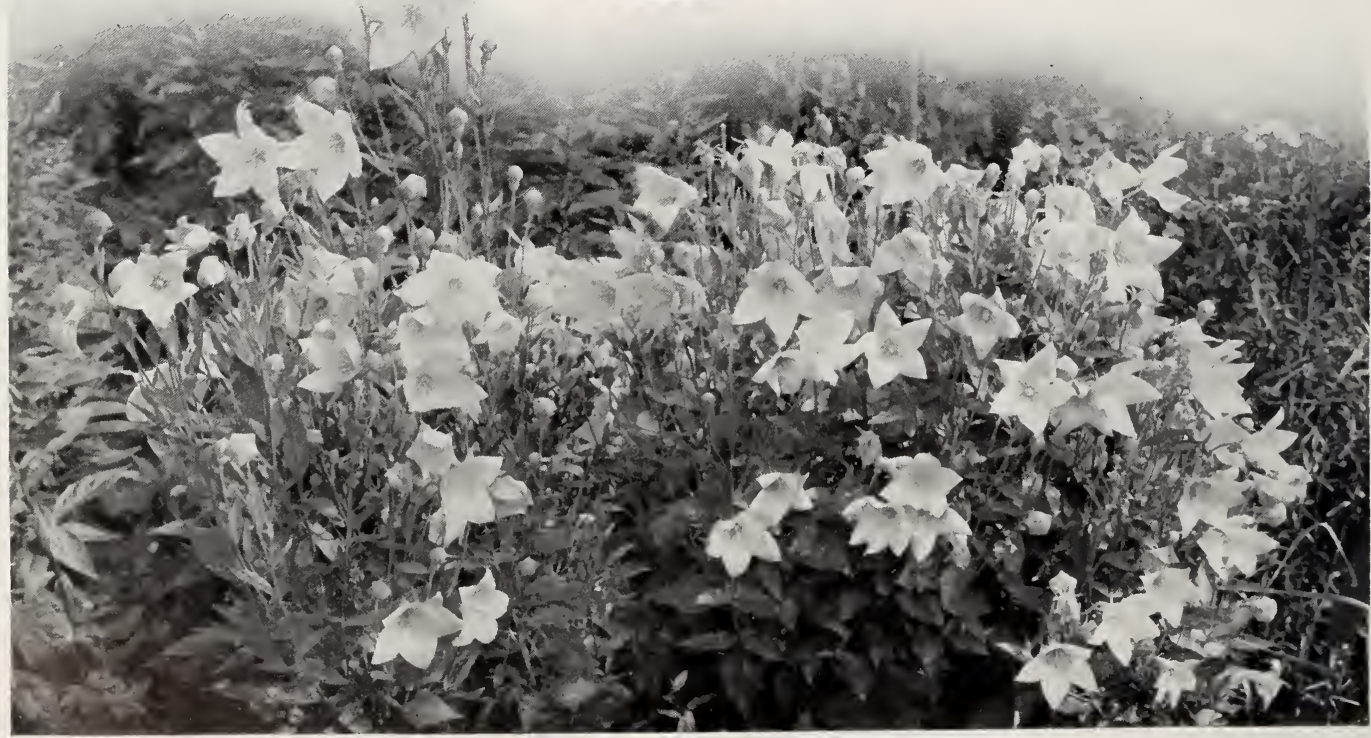

Platycodon grandiflorum keeps up a fine display almost all summer 


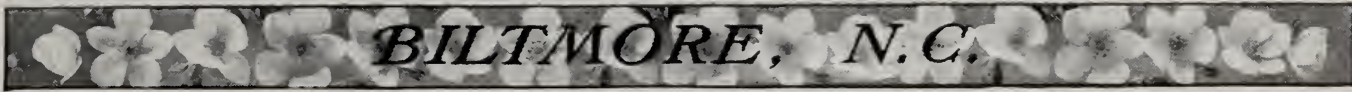

Primula, continued

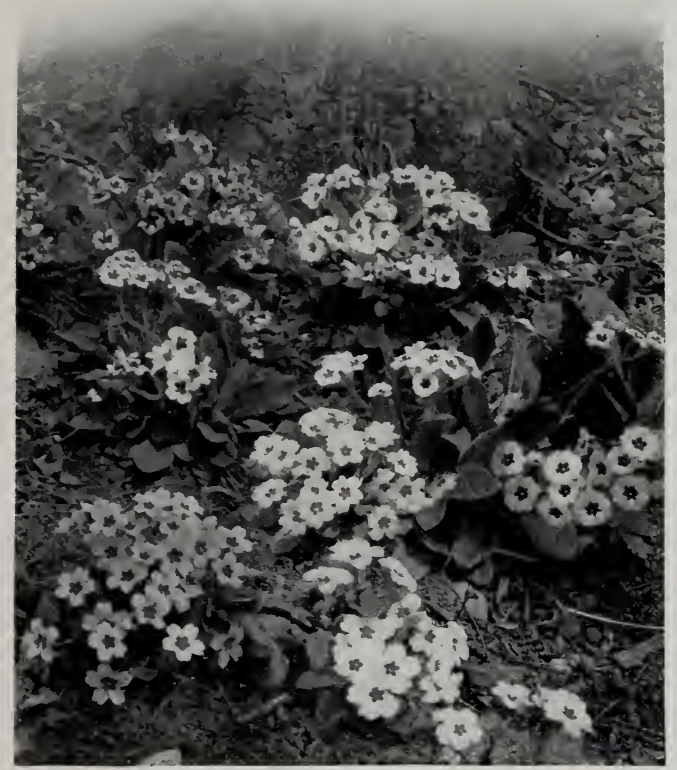

Types of Hardy Primroses

\section{Potentilla . The Cinquefoils}

Potentilla formosa ( $P$. nepalensis). RED-FLOWERED Cinguefoil. A fine erect perennial, with stems i8 inches or more in height, and attractive 5- to 7 -parted leaves near the root. Its single, wine-red flowers are produced in great abundance from June until August. The Potentillas succeed in almost any soil and require little care.

P. tridentata. Evergreen Cinouefoil. A low evergreen plant well adapted for rockeries and as a ground cover. It has very small white flowers, opening in summer, and dark green leaves, thrice divided, assuming rich tones of red and bronze in winter. A very hardy and useful American species for use in places where grass will not thrive.

Either of the above, stcong plants, prepaid, $15 \mathrm{cts}$. each; larger sizes, purchaser paying transportation, 15 cts. and 25 cts. each.

\section{Primula $\cdot$ Hardy English Primroses}

All who have seen how beautiful Primroses can make the early spring of England, are advocates of their wider planting elsewhere. Meadow and orchard and brookside are steeped in their fragrance and carpeted with their flowers. A tradition to the effect that the American climate is inhospitable to the English Primrose still makes it rather rare in our gardens. But some species, notably those described below, really flourish well here with a minimum of care, and their hardiness has been well tested. Not the cold of our winters, but the heat and drought of the American summer and autumn prove trying to some of the less rugged sorts favored abroad. In partially shaded, moist locations, even when neglected, colonies of these plants have graced some of our old gardens for decades of years. As the few essentials to success in Primrose culture become better understood the different species are being used more largely, not only for border work, but for spring bedding, frame culture and house decoration. A clump of blooming Primroses lif ts readily to pot or fern-dish and goes on flowering happily for weeks as a table or window ornament. Literature is full of allusions to the Primrose and it has many endearing popular names. Hardy Primroses are among the earliest, the freest blooming and the richest colored of all our perennials-it is a flower for the million and not for the few.

Primula auricula. Alpine Primrose. One of the prettiest species, much loved for its fragrance and freedom of bloom. The umbels sometimes contain 20 or more flowers, and have a great variety of colors, yellows, with their " merry eyes," predominating. A good, permanent sort, easily established.

P. officinalis. Cowslip. Pretty flowers of bright, light yellow on stems 6 inches to a foot high, a dozen or more in a cluster and all facing one way. The "eye" is usually lighter than the rest of the flower, but the coloring is variable.

P. polyantha ( $P$. variabilis). Polyanthus An exceptionally charming and variable garden form, better known in this country than any other. The flowerscapes are erect and tall, standing well above the long leaves; a good clump has many of them and the trusses are large. The flowers are usually a velvety reddish brown, with bright yellow center and golden border, but vary into self-colored flowers with yellow eyes and lacings. Indeed, this is the most freakish of the species, the hose-in-hose being one of its forms. One of the best sorts for forcing, spring bedding and cutflowers.

P. vulgaris ( $P$. acaulis). ENGLish Primrose. This is the favorite wild Primrose of England and Scotland having, in the wild state, canary-yellow flowers of delightful fragrance. A low, tufted plant, about 6 inches high, very free and early-blooming, to which cultivation has brought various colors and forms.

Any of the Primulas, strong plants, prepaid, $15 \mathrm{cts}$. each; larger plants, purchaser paying transportation, $15 \mathrm{cts}$. and $25 \mathrm{cts}$. each.

The plants were splendid specimens and reached me in good condition, beautifully packed. Apparently they are all living and doing well. I can scarcely tell you how much pleased I and doing well. I can scarcely tell you how much pleased the fifteen plants I purchased of you just a year ago, I did not lose one, which is most gratifying.
Yours very truly, WM. M. REDWOoD, Yours very truly, WM. M. R
Asheville, N. C., May 4, Igog.

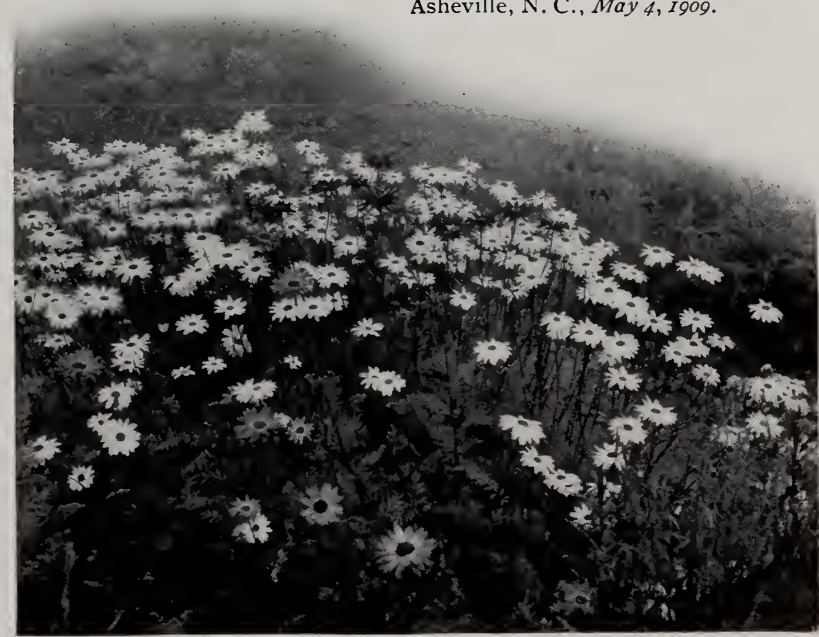

Pyrethrum hybridum, singled-flowered (see page 52) 


\section{BILTMORE NURSERY . NET}

\section{Pyrethrum}

Pyrethrum hybridum (Chrysanthemum coccineum). PERSIAN I)AISY. To all who wish an unstinted supply of flowers for cutting we commend the Pyrethrums. They are as beautiful in many colors as the Marguerites are in two or three, and bloom even more abundantly. If cut back after their grand spring overture, new growths and new flowers are produced through autumn. They have larger flowers than the Marguerites, the same perfection of grace, the same long, supple stems, with a petal-texture that is not injured by storms or hot sunshine. A good, rich, loamy soil and mulching during dry weather help to secure larger, more brilliant flowers and a longer succession of them.

P. uliginosum. Giant Daisy. An unusually tall, fine, single Pyrethrum, with great white daisies freely produced from July to September. The plant grows 3 to 5 feet high and the flowers are sometimes 3 inches wide.

Either of the Pyrethrums, strong plants, prepaid, 15 cts. each ; larger sizes, purchaser paying transportation, $15 \mathrm{cts}$. and $25 \mathrm{cts}$. each.

\section{Ranunculus}

Ranunculus repens flore pleno. Creeping ButTercup. A very bright-flowered little plant that raises its thick crop of golden buttons to a height of 6 to 12 inches during May and June. The flowers are very double; the leaves feathery. A good plant for childrens' gardens, as well as for flower and wild gardens. Strong plants, prepaid, I5 cts. each ; larger sizes, purchaser paying transportation, I5 $\mathrm{cts}$. and $25 \mathrm{cts}$. each.

\section{Rosmarinus}

Rosmarinus officinalis. ROSEMARY. Of all the sweet old-fashioned aromatic herbs this one has perhaps the longest list of reputed virtues, and, next to Lavender, the most delightful odor and attractive appearance. From 2 to 4 feet is its height in modern gardens, but "It overtoppeth all the flowers in the garden," quoth old Roger Hacket, in I607. "It helpetl the braine, strengtheneth the memorie, and is very medicinable for the head." Truly Rosemary should be grown plentifully in these strenuous times, even if it does not attain the stature credited to it in its home by the Mediterranean! It is a shrubby plant with dark, stiff leaves, and small, axillary light blue flowers in early spring, most attractive to the bees. Rosemary is not as tender as reputed. It
Rudbeckia laciniata Golden Glow

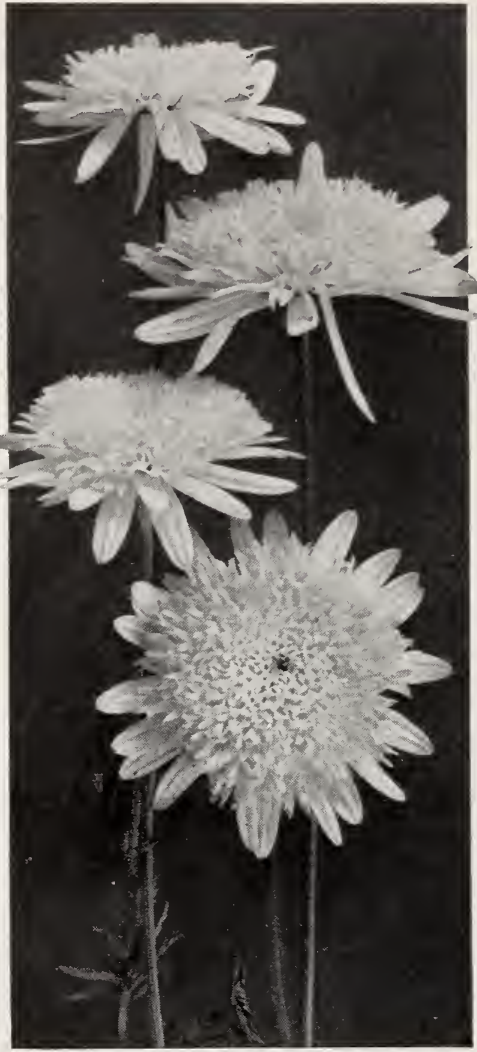

Pyrethrum hybridum, Double-flowered
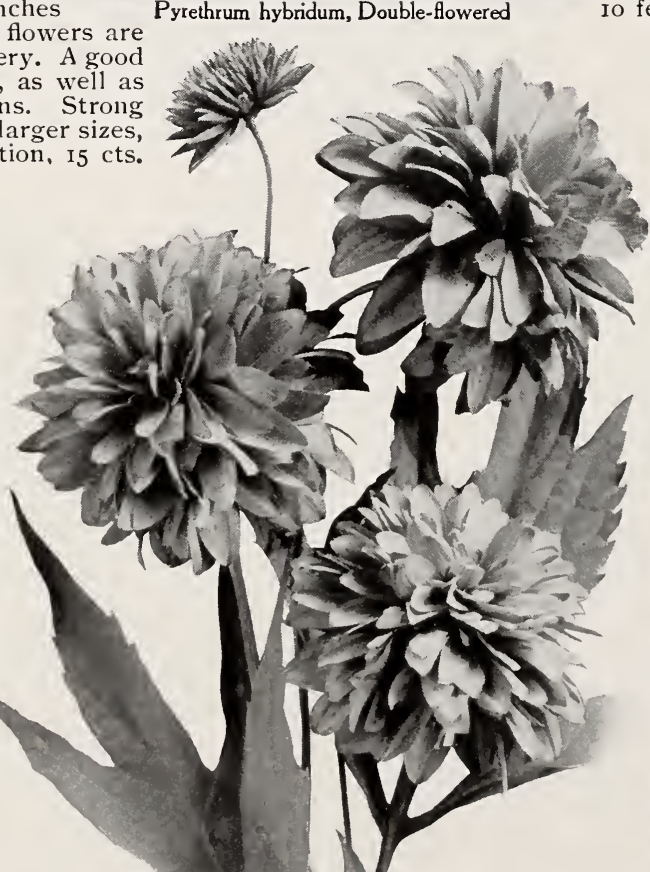
rary screens and distant garden pictures.

R. speciosa. Showy ConeFLOWER. A handsome native species, 2 or 3 feet in height, with leafy, branching stems and numerous brilliant yellow blooms, ringed with orange about the brown-purple central disk. Makes a good border for the taller species above.

R. subtomentosa. SWEET CONEFLOWER. Dwarfer, forming a densely branched pyramid about $2^{1 / 2}$ feet high that looks, for a good part of the summer, as if it were merely a mound of bright lemon-yellow flowers. Can also be used with good effect in front of Golden Glow.

Any of the Rudbeckias, strong plants, prepaid, 15 cts. each; larger sizes, purchaser paying transportation, 15 cts. and $25 \mathrm{cts}$. each.
The trees and shrubs were very nice, and the evergreens especially so. I want to personally thank you for the Hydrangea sent gratis. R. N. KFSTERSON, Greenwood Cemetery Co., Knoxville, Tenn., May 17, I909. 


\section{C) A BILTMORE, N.C.N R WS}

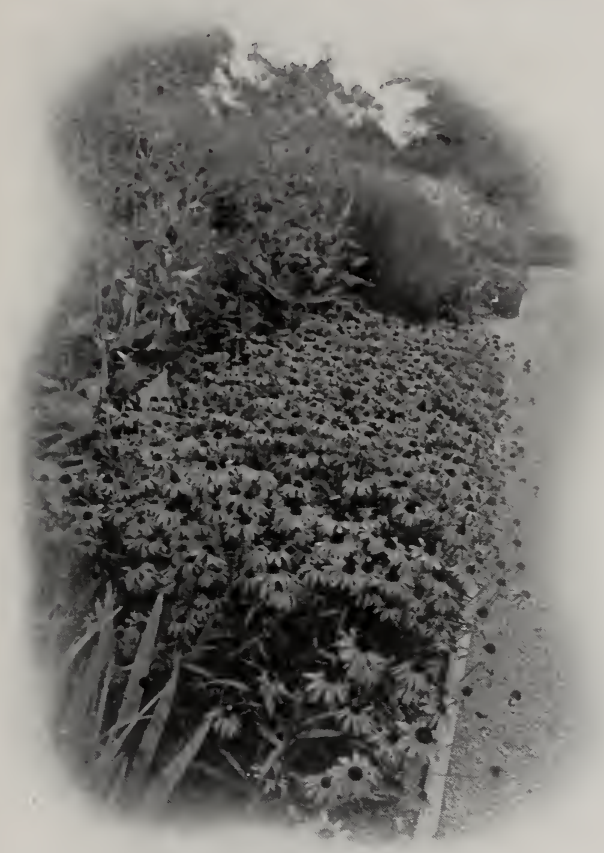

Rudbeckia speciosa (see page 52)

\section{Salvia}

Salvia azurea grandiflora. Rocky Mountain SAgE. The perennial Sages have blue flowers gracefully disposed and, in several sorts, silvery pubescent leaves. This delightful species grows from 2 to 3 feet high and opens many loose panicles of pure blue flowers in August and September. Exquisite for cutting and a border gem.

S. pratensis. MEADOw SAGE. The rare, deep blue flowers of this Sage are abundant from May to July, giving, with the above species, a long succession of flowers for cutting in a color much prized.

Either of the Salvias, strong plants, prepaid, $15 \mathrm{cts}$. each; larger sizes, purchaser paying transportation, 15 cts. and 25 cts. each.

\section{Sanguinaria}

Sanguinaria canadensis. BLOODROOT. The enthusiasm with which we greet the first few flowers of early spring, peering out into a world still cold, is due alike to their beauty and bravery. The Bloodroot's thick, strong leaves, each curled firmly about a tender flower-bud, appear in March or April. Strange that to the thick red sap, leaving so dark a stain, the world should owe such an early and yet such an ethereal blossom, with many slender, starry white petals encircling a disk of gold! It is only in stormy weather that the flowers are transitory. In mild spring weather they ordinarily close at night, opening wide next morning and persisting usually for at least two days, - longer than most of the Poppyworts. Relays of blossoms crowd up plentifully for some weeks after the first ones have faded. There is much vigor and energy in the thick, fleshy roots of this wilding, and appreciation of garden hospitality is quickly shown by their spreading into broad masses, very beautiful for spring gardening, especially when combined with Trilliums and similar early-blooming plants.
Sanguinaria canadensis, continued

In rich soils the flower-scape lengthens to 6 or 8 inches and the flower measures 2 inches or more across, becoming quite showy. The irregularly and deeply lobed leaves are a silvery, glaucous blue, sometimes 8 inches broad, and remain bright for most of the season. Strong plants, prepaid, 15 cts.; larger sizes, purchaser paying transportation, $15 \mathrm{cts}$. and $25 \mathrm{cts}$. each.

\section{Santolina}

Santolina chamaecyparissus. LAVENDER COTTON. This quaint and altogether charming little evergreen deserves wider planting. It is half-shrubby, low-growing, densely branched, and when cut back, as is usual in border culture or for specimens, makes dense mounds or cushions of silvery gray leaves, with small, globular heads of golden yellow flowers suggesting golden pins. Strong plants, prepaid, I5 cts. each larger sizes, purchaser paying transportation, is cts. and 25 cts. each.

\section{Saponaria}

Saponaria ocymoides. SOAPWORT. A gay-flowered, half-trailing plant, growing 6 to 9 inches high, with many branches terminating in loose, broad cymes of bright pink flowers in summer. Easily established in almost any soil and similar to some of the creeping Phloxes in effect. Strong plants, prepaid, 15 cts. each ; larger sizes, purchaser paying transportation, $15 \mathrm{cts}$. and 25 cts. each.

\section{Saxifraga}

Saxifraga cordifolia. Rockfoil. A low plant, of bold habit, forming masses of large, handsome, glossy leaves, beautiful throughout the season. Very early in spring appear dense panicles of pretty lilac-pink flowers, making the plant doubly attractive and interesting. It grows about a foot high and succeeds better in our climate than most other species. A mulch of leaves in winter is beneficial. Strong plants, prepaid, $25 \mathrm{cts}$. each; larger plants, purchaser paying transportation, 25 cts. and 35 cts. each.

The shrubs arrived in most excellent condition and I wish to thank you for your generosity Yours very truly, MRS. Chas. E. QuinlaN, Waynesville, N. C., Dec. 3. Igog. 


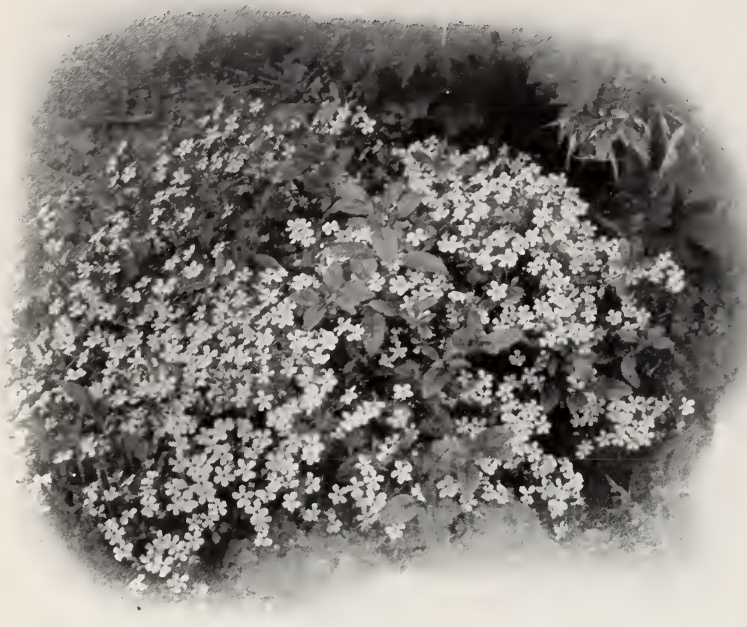

Saponaria ocymoides (see page 53)

\section{Scabiosa}

Scabiosa caucasica. Scabious. A choice hardy perennial of the easiest culture in well-drained, sunny soils, where it spreads masses of delicately cut foliage as a foil to its distinct, long-stemmed, flattened heads of lovely lavender-blue flowers. One of the best hardy plants grown for cut blooms. Strong plants, prepaid, I5 cts. each ; larger sizes, purchaser paying transportation, $15 \mathrm{cts}$. and $25 \mathrm{cts}$. each.

My order No. F I27I received today and plants came in fine condition. They are the best and largest mailing plants I have ever received from any nursery, and packed in the best manner ossible. I want to thank you for your promptness in sending and the excellent plants which you sent. Respectfully, Mrs. J. M. SHOR ROCK, Westport, Mass., April 27, I909.

\section{Sedum - The Stonecrops}

This is one of the oddest and most interesting plant-groups in our whole outdoor flora; so varied, too, in character that its different members help to solve a number of garden problems. Although all the species have succulent leaves, these are very differently arranged and show dozens of forms so diverse that they seem entirely unrelated. The flowers are usually small, but are grouped into numerous showy cymes or clusters. One common characteristic, however, is their willingness to grow in any welldrained, sandy soil. They are both rock-ioving and sun-loving, disliking above all things, a wet soil in winter.

Sedum acre. Mossy StONecrop. Wall PePPER. A low, spreading, moss-like species, 2 or 3 inches high, useful in many ways and always attractive. In early summer it is a mass of starry yellow bloom. A favorite for carpeting bare spots and for pockets in rock yardens.

S. album. White Stonecrop. Flowers white, with reddish anthers, in abundant branching cymes. The bright green leaves are half an inch long, the plant 4 to 6 inches high. Is used like the Moss Pink

S. maximum. LARGE STONECROP. The large and fleshy leaves are densely disposed; theclustered stems I5 to 20 inches high; the flowers waxen white, with pink centers.

S. maximum atropurpureum. PURPLE STONECROP. Similar, but has dark bronze-purple leaves.

S. pulchellum. Widow's CRoss. Of especial beauty and daintiness. The plant is tiny, only 3 to 6 inches high, spreading its stems and minute leaves over the surface of the ground in most engaging fashion. The leaves, at first bright green, change to rich tones of red and purple, contrasting brightly with the gracefully arched cyme-tendrils of pink or white flowers. Native of the Southern States.

S. sexangulare. DARK Green Stonecrop. Forms a fine ground cover on account of the dense moss-like

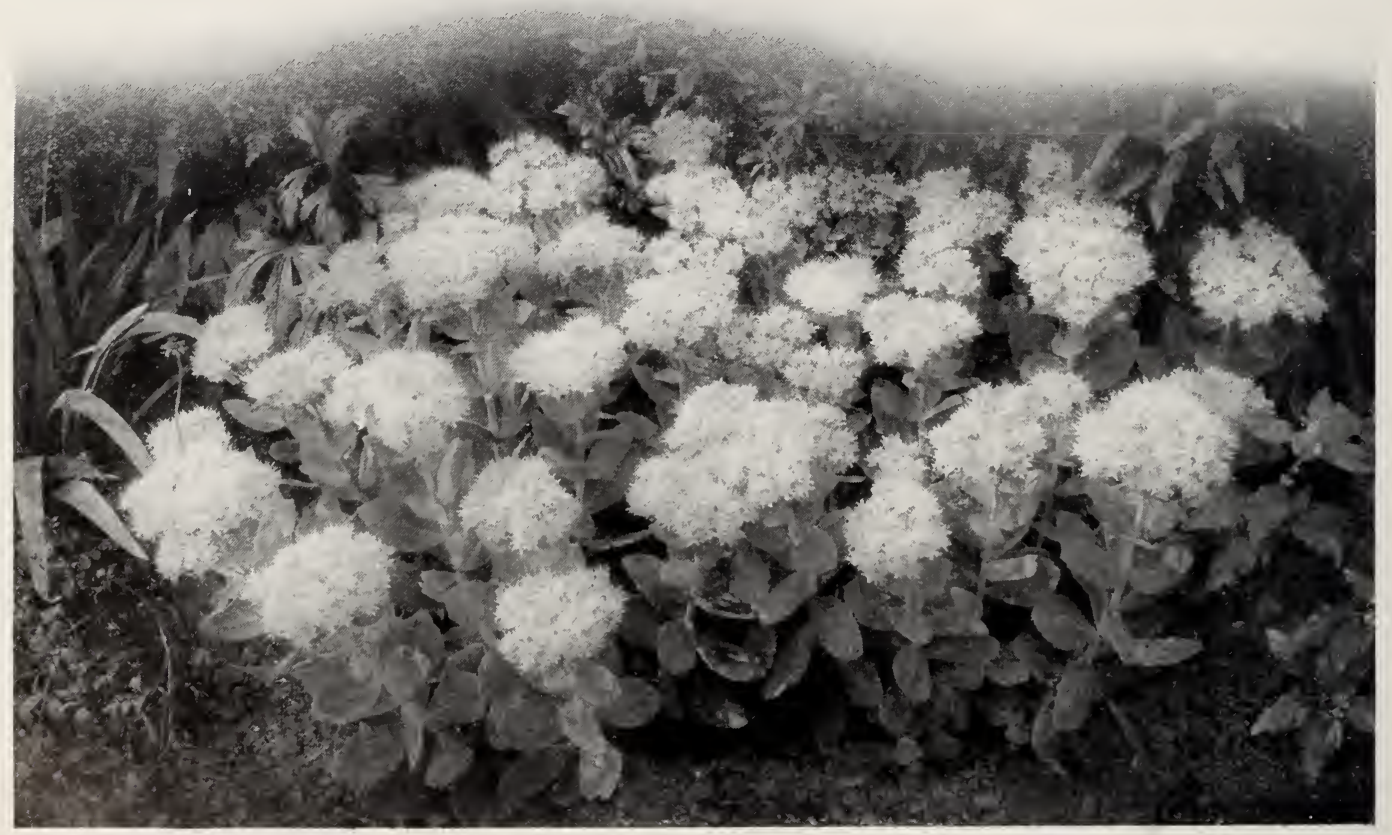

Sedum spectabile, one of the most interesting plants of our gardens (see page 55) 


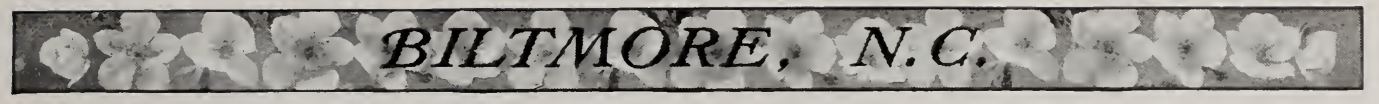

Sedum sexangulare, continued

growth of the slender branches. The yellow flowers ate abundant in early summer above short, dark green, thick-set leaves. 3 to 6 inches high.

S. spectabile. BRILLIANT STONECROP. This tall, bold, handsome species is remarkably distinct and makes one of our best late-blooming border plants. The rich, glaucous leaves that clothe the base of the 2 -foot stems are always effective, but when the great, flat cymes of rose-colored flowers appear the plant is notably beautiful.

S. spectabile atropurpureum. DARK-FLOWERED STONECROP. Similar to the preceding, but has deep rosy crimson flowers.

S. spurium. SPREADING STONECROP. Of peculiar growth, with long, trailing stems that take root at the joints. The leaves are irregularly cut or toothed and glaucous green; the flowers are pink, with reddish anthers.

S. spurium coccineum. Crimson-Flowered STONECROP. A variety of the last, with rich crimson flowers.

S. ternatum. WILD STONECROP. A handsome native tufted species, with creeping stems and leaves disposed in rosettes at the tips of the branches. The flowers are white, in branching cymes.

Any of the Stonecrops, strong plants, prepaid, 15 cts. each; larger sizes, purchaser paying transportation, 15 cts. and 25 cts. each.

SPECLAL OFFER. A collection of six Stonecrops, no two alike, our selection of varieties, strong plants, prepaid, 60 cts.; larger sizes, purchaser paying transportation, 60 cts. and $\$ 1$.

\section{Sempervivum}

The Sempervivums, or Houseleeks, are evergreen succulents, with some characteristics of the Sedums, but increase by rosettes sent out from the parent plant. They are grown chiefly for their beautiful leaves, which are often bright colored at their tips. Their flowers are larger than those of the Sedums, but in less. showy clusters. They are of the easiest culture and useful for covering dry banks, sandy wastes and rorks. IVe offer a variety of the best species. Strong plants, prepaid, 15 cts. each; larger sizes. purchaser paying transportation, $15 \mathrm{cts}$. and $25 \mathrm{cts}$. each.

\section{Shortia}

Shortia galacifolia. In horticultural journals this rare and most local of historic American plants has been given much space It is a beautiful, shade-loving evergreen, native to the mountains of the Carolinas, and the story of its rediccovery among them after a long lapse of years has been frequently told. The leaves are oblong or rounded, resembling those of the Galax, its neighbor in our woods. Its white, nodding flowers, about an inch across, suggest thuse of a Primrose. They appear on slender, wiry stems, 3 to 6 inches high, in early spring. Entirely hardy. Strong plants, prepaid, $25 \mathrm{cts}$. each, larger plants, purchaser paying transportation, $25 \mathrm{cts}$. and $35 \mathrm{cts}$. each.

\section{Solidago - The Goldenrods}

We cannot spare entirely to wild gardens the glitter of the Goldenrods. Their golden plumes are needed as a complement to the blue stars of the Michaelmas Daisies which, in culture, have captivated all hearts, and to show in our gardens a sympathetic appreciation of Nature's great autumn pageant. Intelligent transplanting and cuttingback will give later and lighter touches of color for garden enjoyment after the glamor outside is gone. The species below respond with rich, full plumes or "rods" to cultivation, and we consider them among the best.

\section{Solidago, continued}

Solidago canadensis. Canadian Goldenrod. Conspicuous for its height, poising rich plumes composed of small, short flower-heads massed in great numbers on the recurving branches of tall, stout stems. 3 to $6 \mathrm{ft}$.

S. nemoralis. GREY GOLDFNROD. Lower-growing, with showy rayed flower-heads forming a pyramidal, recurved, usually one-sided panicle. The silvery pubescence on leaves and stems gives the plant a hoary look. 3 feet.

S. rigida. HARD-LEAVED GoldenRod. Bold and distinct in leaf and flower, with quite large, flattened compound corymbs terminating the stout, simple stems. 2 to 5 feet high

S. speciosa. Showy GoldenRod. A particularly fine species, with large lower leaves, stout stems 3 to 6 feet high, and numerous erect racemes which form a great glowing pyramidal panicle.

Any of the Solidagos, strong plants, prepaid, $15 \mathrm{cts}$. each; larger sizes, purchaser paying transportation, 15 cts. and 25 cts. each.

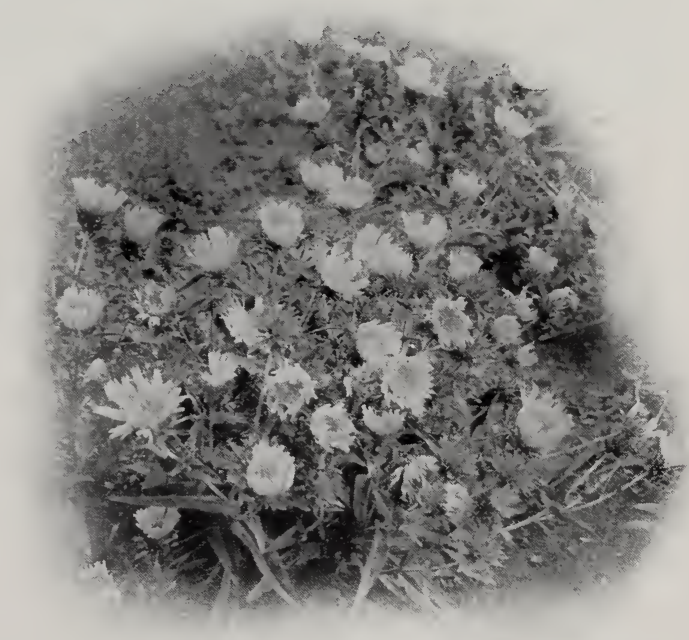

Stokesia cyanea (see page 56)

\section{Statice}

Statice latifolia. SEA Lavender. From a deep, strong root this fine perennial sends up a mound of dark green leathery leaves, and cruwns them in midsummer with large, feathery panicles of small blue flowers, on scapes about two feet high. Another pretty blue flower for cutting. The plant requires a sunny spot and a rich, deep soil. Strong plants, prepaid, I5 cts. each; larger sizes, purchaser paying transportation, 15 cts. and $25 \mathrm{cts}$. each.

\section{Stenanthium}

Stenanthium robustum. Mountain Feather FLEece. A tall and handsome perennial, native to the Southern Alleghanies and recently introduced for garden culture. The pure white flowers are borne in graceful compound panicles often 2 to 3 feet long. The plant grows from 3 to 5 feet high and a good clump of it in full bloom is a beautiful sight. Entirely hardy, blooming for several weeks in summer. Strong plants, prepaid. $35 \mathrm{cts}$. each; larger sizes, purchaser paying transportation, $35 \mathrm{cts}$. and $50 \mathrm{cts}$. each.

I beg to acknowledge receipt of box of plants recently ordered we may have success in growing them. I wish to thank you we may have success in growing them. I wish to thank you for your promptness in shipping as well as for your courteous
letter as to how to plant. Yours very truly, R. M. DAIN, Edge. wood, $\mathrm{Pa}$., May 4, I909. 


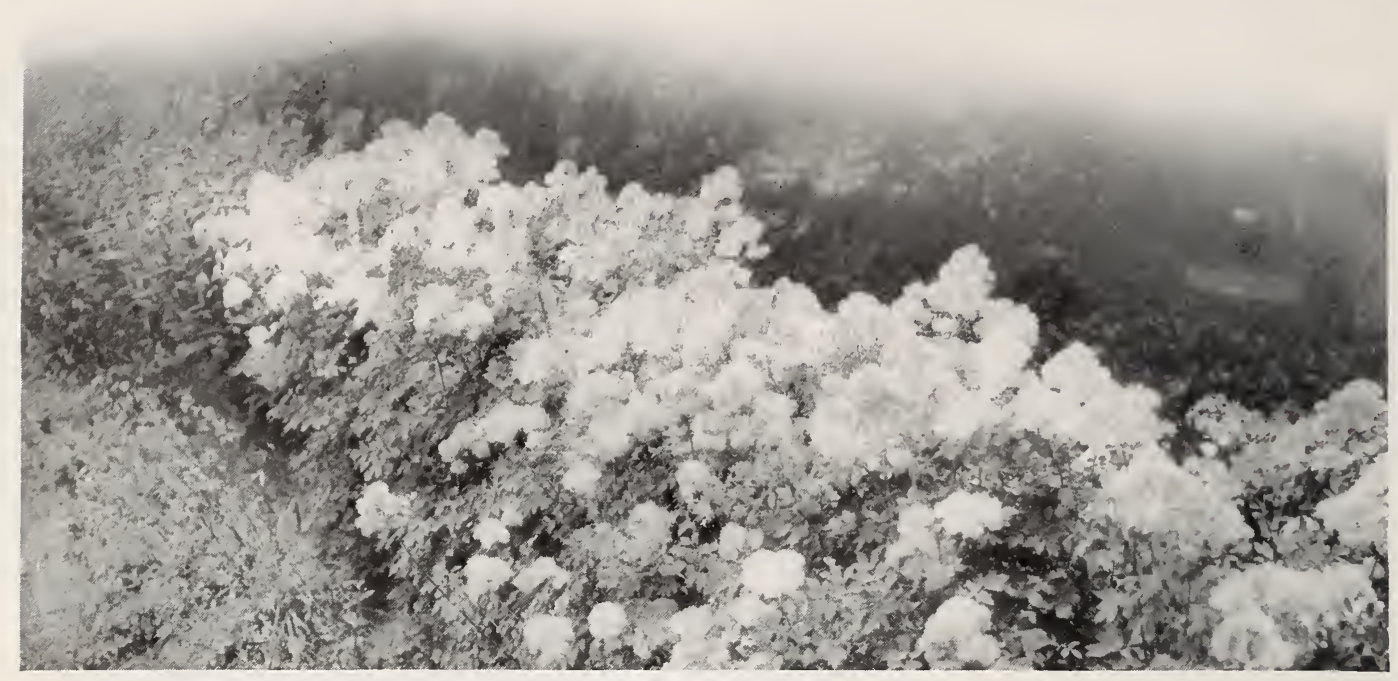

Thalictrum aquilegifolium

\section{Stokesia}

Stokesia cyanea. STOKES' AsTER. This beautiful native of the Carolinas made its debut in England many years ago, furnishing there, in late fall, the chief supply of blue flowers to the Covent Garden market. Greatly improved by selection, it made a second debut in America a few years since and has been received with great favor. The plant grows from one to two feet high, branching and bearing many large, clear blue flowers, 3 to 4 inches across, resembling semidouble China Asters. In dry, well-drained soil it proves quite hardy. The largest blue flower of the wonderful Composite family. Strong plants, prepaid, I5 cts. each ; larger sizes, purchaser paying transportation, i5 cts. and $25 \mathrm{cts}$. each.

\section{Tanacetum}

Tanacetum vulgare crispum. CURLY-LEAVED TANSY. In herb borders of the old-time garden there were always some clumps of Tansy. This curly-leaved species deserves a place in the flower or shrub border. Its deep green, scented leaves breathe out a refreshing odor as you pass and are as beautifully crisped and curled as those of some ferns. A robust plant, growing 2 or 3 feet high and crested in midsummer with many small, bright yellow blossoms. Has well-known medicinal uses. Strong plants, prepaid, I5 cts. each ; larger sizes, purchaser paying transportation, $15 \mathrm{cts}$. and $25 \mathrm{cts}$. each.

\section{Thalictrum}

Thalictrum aquilegifolium. MEADOW RUE. The Meadow Rues all have exquisite foliage, in shape and multiple divisions suggesting the Columbines, in delicate texture and airy poise the pinnules of the Maidenhair Fern. The leaves of this species are large, deep green above and silvery beneath, giving delightful sylvan effects when stirred by the wind. From the tall stems, in midsummer, appear large, fleecy, compound panicles of small white or cream-colored flowers. A good mass of this Rue makes a delightful study in delicate color and foliage tints. The smaller, fresh young leaves are beautiful for cutting. Strong plants, prepaid, $15 \mathrm{cts}$. each: larger sizes, purchaser paying transportation, I5 cts. and 25 cts. each.

\section{Thymus}

All the Thymes have a pleasant, mint-like fragrance, their name-from thumos, courage, strength - fitting the reviving quality of their scented leaves. Any one who has noticed the feeling of wonderful refreshment gained in working over or resting near beds of Thyme and other fragrant herbs, will bear witness to this virtue. The Thymes are useful in borders, rockwork, edgings and for ground-covers. The creeping habit of some species, the ability of all to persist in dry, poor soils, and the fragrance of their sometimes evergreen leaves, give them a number of important uses.

Thymus citriodorus. LEMon THyile. An attractire little trailing plant especially useful for evergreen borders and cushioning rockwork. The tiny, round, persistent leaves have tinier flowers in whorls from their axils. Frequently used in seasoning.

T. lanuginosa. Downy THyme. A quaint little species with small, downy, persistent leaves and minute flowers. Especially adapted for dainty evergreen edgings.

T. serpyllum. Mother of THYME. The familiar evergreen Thyme used for edgings in old gardens. The stems are slender, creeping on the surface of the ground; the leaves are mere evergreen dots or dashes; the flowers are mauve, from the leaf-axils.

T. vulgaris. Common Thyme. The old Thyme of herb plots, much prized in cookery. The stiff, wiry stems are I2 to I 8 inches high, the leaves linear, the lilac flowers in terminal spikes. One of the hardiest and most permanent of plants.

Any of the above, strong plants, prepaid, $15 \mathrm{cts}$. each larger sizes, purchaser paying transportation, $15 \mathrm{cts}$. and 25 cts. each.

\section{Tradescantia - The Spiderworts}

The Spiderworts have much individuality and beauty, as well as permanence and hardiness. The plants are more or less succulent in texture, their jointed stems and linear leaves suggesting the grasses. They are quite vigorous, thriving in almost

Many of the hardy flowers are worthy of pot culture and special exhibition. Take for instance, the Epimediums, of which Wilhelm Miller writes: "A collection of these plants should make a charming study. The whole tribe to which it belongs is exceptionally interesting, and is one of the most striking of those rare cases in which the cultural, botanical and artistic points of view have much in common. A well-grown collection of these plants in pots would almost certainly win high praises and prizes.' 


\section{BILTMORE, N.C. N N W}

Tradescantia, continued

any sunny spot, soon forming large clumps I to 2 feet high, that open hundreds of showy, three-petaled white or blue flowers every morning for weeks, and, in some cases, for months together. The three species offered here are native to the Southern Alleghanies.

Tradescantia montana. MOUNTAIN SPIDERWORT. The delicate bluish purple flowers of this species appear in early summer. Leaves and stems form a dense mound about 12 to 18 inches high with the cheery blossoms scattered over its surface.

T. reflexa. Glaucous SPIDERwORT. The contrast between the bright blue flowers and glaucous foliage of this species is striking. The plant is vigorous, growing about 2 feet high, with clustered stems and very long, slender, drooping leaves of bluish green. The delicate blue petals of the flowers are a mere film of color. They last but for a day, but multitudes of fresh ones appear every morning for several weeks of summer.

T. virginica. COMMON SPIDERWORT. Similar to the last in height and habit, save that the leaves are a rich green. The flowers are violet-blue, an inch or more across, very showy and abundant for the greater part of the summer. Plants of this are found still growing in old cottage gardens from beside which the house crumbled years ago.

T. virginica alba. A variety of the preceding species having pure white flowers.

Any of the Tradescantias, strong plants, prepaid, 15 cts. each; larger sizes, purchaser paying transportation, $15 \mathrm{cts}$. and $25 \mathrm{cts}$.

SPECIAL OFFER. A collection of three distinct Spiderworts, your selection of varieties, strong plants, prepaid, 35 cts.; larger sizes, purchaser paying transportation, $35 \mathrm{cts}$. and $50 \mathrm{cts}$.

\section{Trillium}

Nature held even more strictly to the rule of three in fashioning the Trillium than in the Tradescantia, for leaves, petals and flowers are all in triangles. Yet it is an example of how lovely even angular things may be, in flowers, for to the Trillium the triangles have merely given a piquant personality.

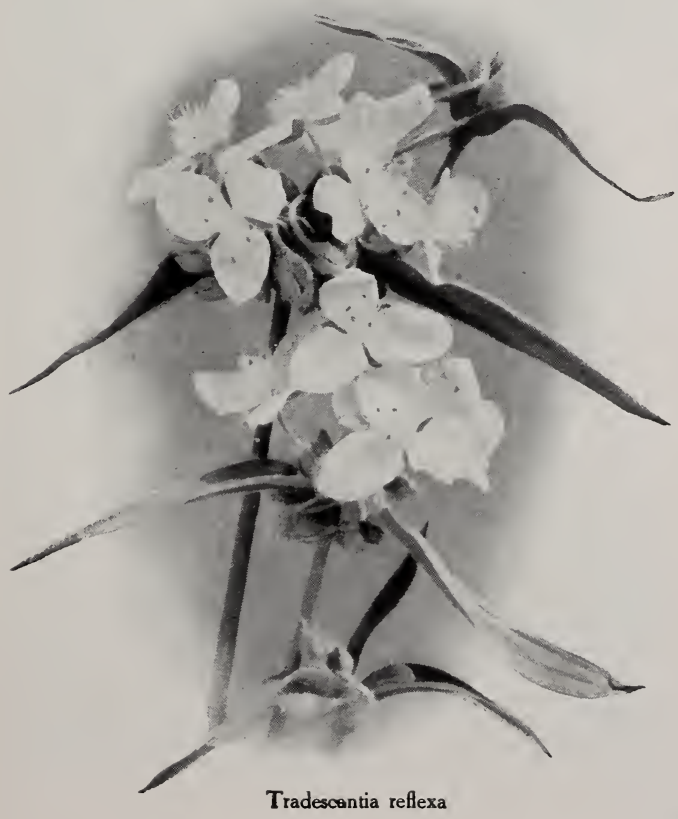

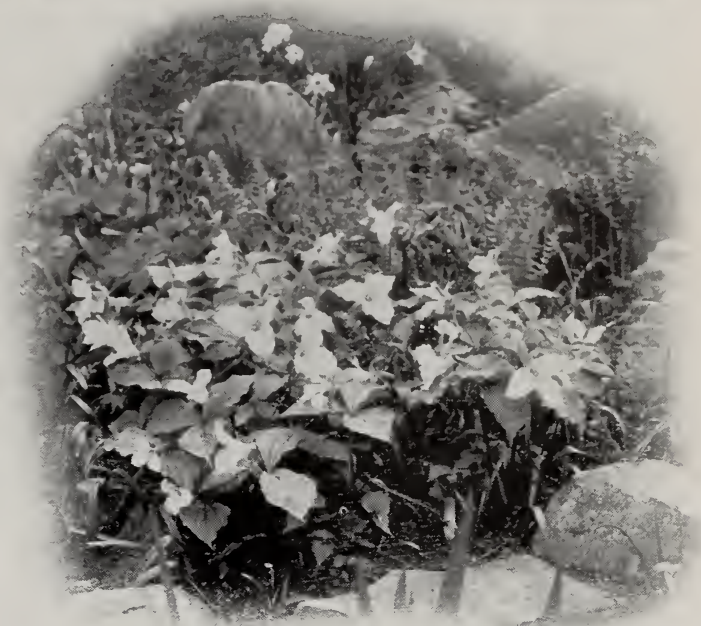

Trillium grandiflorum

Trillium, continued

Our White Wood Lily is a much-honored flower abroad, and all who will naturalize it along with Bloodroot, by hundreds under trees, or in shaded spots in the garden, as a noted gardener suggests, will find the honor bestowed worthily.

Trillium erectum. WAKE ROBIN. The earliest species of all to flower, spreading its reddish brown corolla in jaunty fashion above the three deeply veined, shining leaves, in April or May.

T. grandiflorum. WHITE IVOoD LILY. A little later, on a somewhat longer stem open the "chaste white triangles" of the large white Trillium. Professor Bailey says this is one of the relatively few flowers that is showy without being coarse. The three deep green, shining leaves just beneath its nodding flower greatly enhance its beauty, and the stem, which sometimes lengthens to IS inches in cultivation, is tall enough to give true stateliness. The root is a rounded tuber, and flourishes in deep, rich leaf-mold in partial shade.

Either of the Trilliums, strong plants, prepaid, $15 \mathrm{cts}$. each ; larger sizes, purchaser paying transportation, 15 cts. and 25 cts. each.

\section{Tritoma}

Tritoma pfitzeri (Kniphofia), RED-HOT POKER, FLAME Flower. Used first merely in bold groups among shrubbery in a tentative way, the Tritoma gave such vivid effects and proved so hardy that it is now one of the great bedding plants, the richest-flowered of any in its season. The plant forms a grand circle of swordshaped leaves from the midst of which rise several scapes 4 to 5 feet high. The upper foot or more of the stem is a brilliant spike of overlapping, tubular, drooping flowers, each more than an inch long, and of "fiery, untamed red." A first sudden view of the flowers is startling and rocket-like in effect. Under date of October I5, Mr. IVilliam Falconer writes of this plant: "Torch Lily, or Flame Flower is now grand in the Park nursery, where we have a large bed of it containing hundreds of torches all afire. There is nothing else, indoors or outside, in the way of flowers, to compare with this mass of floral fire, and its continuing now, after frost has come and destroyed the other pretentious flowers, makes it doubly valuable." T. pfitzeri is an improvement over older kinds in its earlier and more continual and profuse production of finer flowers from August to November. Give the roots a good protective mulch in winter in cold climates. Strong plants, prepaid, I5 cts. each; larger sizes, purchaser paying transportation, $15 \mathrm{cts}$. and $25 \mathrm{cts}$. each. 


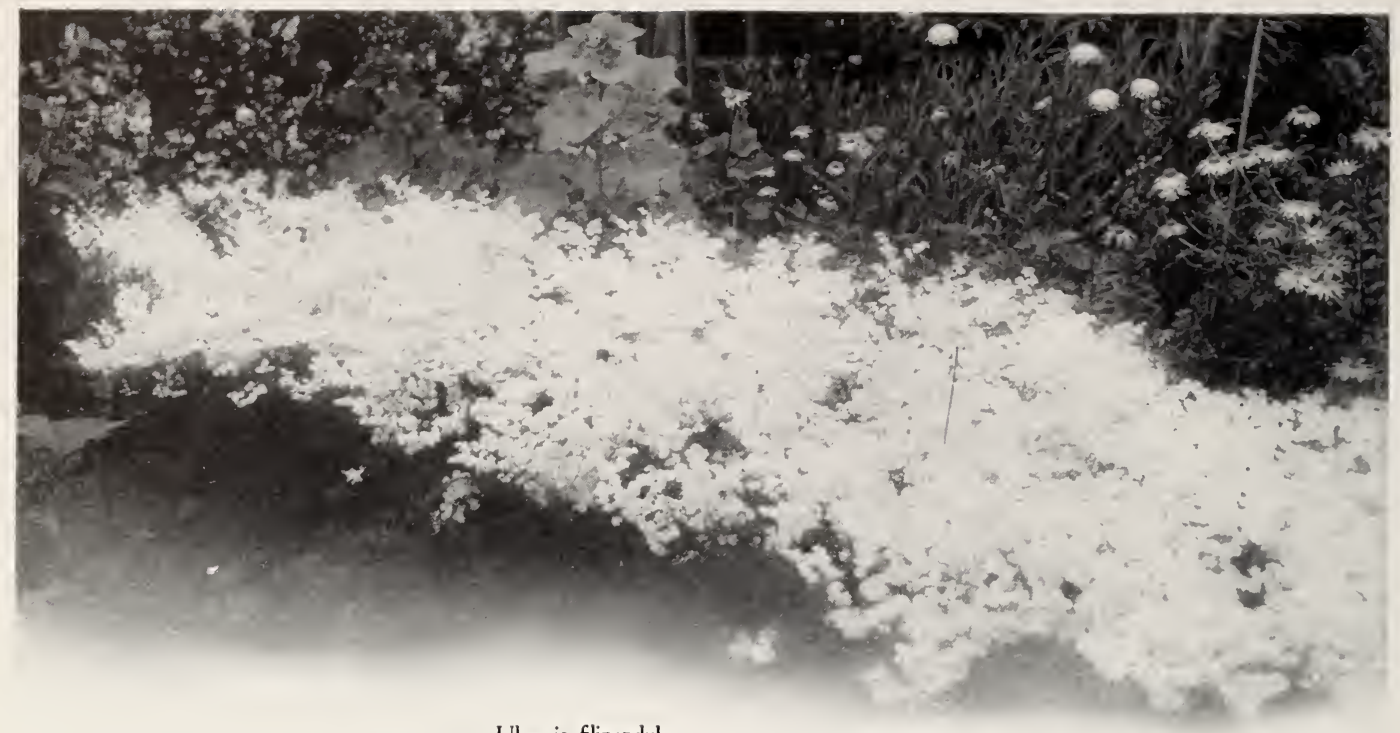

Ulnaria filipendula

\section{Trollius}

Trollius europaeus. Globe Flower. Sometimes called Giant Buttercup, because, on a larger scale, its dark green, finely cut foliage and double, rich yellow flowers recall the Crowfoot family. It is one of the early and particularly welcome spring flowers that does not forsake us with the coming of hot weather. A good border mass keeps its great golden bosses of flowers sparkling until August. These blossoms are from $I^{1 / 2}$ to 2 inches across, beautifully cupped and rounded and carried well above the foliage on stems 2 feet high. It succeeds well in a semi-shaded position and, preferably, in light, well-drained soil. Strong plants, prepaid, I5 cts. each; larger sizes, purchaser paying transportation, 15 cts. and 25 cts. each.

\section{Tunica}

Tunica saxafraga. SAXIFRAGE PINk. A pretty, tufted, prostrate plant, that suggests the Gypsophila in the relicate, branching habit of its wiry stems, and the Dianthus in the formation of its small, rosy white, lilac or pale purple flowers, daintily notched along the edges. It blooms all summer and is useful alike is rock garden or border. Height, 6 to Io inches. Strong plants, prepaid, $25 \mathrm{cts}$. each; larger sizes, purchaser paying transportation, $25 \mathrm{cts}$. and $35 \mathrm{cts}$. each.

\section{Ulmaria - The Herbaceous Spireas}

Although the Ulmarias vary greatly in height and considerably in color, they all have handsome fernlike foliage in rosettes about their roots and their showy terminal corymbs of flowers are feathery in effect. They bloom in early summer and midsummer, making handsome border plants, the majority of them delighting in rich moist soil, and enduring some shade. Their long, pliant stems give them a billowy grace, that in the white-flowered species planted en masse has been likened to white caps of sea-foam.

Ulmaria filipendula (Spircea filipendula). HERBACEOU MEADOW SWEET. From a close, flat rosette of dark green, fern-like leaves, rise several slender stems that, at the height of a foot or more, break into an inflorescence of marvelous grace, floating out horizontally into tender pink buds and fleecy white open flowers. This is a sun-loving species and likes a drier soil than the others for its tuberous roots. It blooms in June and may be had in double- or single-flowered forms.
Ulmaria, continued

Ulmaria pentapetala (Spircea ulmaria). QUEENOF THE MEADOw. Sometimes called "Honey-sweet" from the fragrance of its fine clusters of creamy white flowers carried with stately grace on stems 3 to 4 feet tall, in July and August. Its lateral leaflets resemble somewhat those of the Elm, but the handsome lower ones are compound and variously lobed.

U. pentapetala flore pleno. DOUBLE-FLOWERED ULMARIA. Flowers very full and double, pure white, more durable than in the single form above.

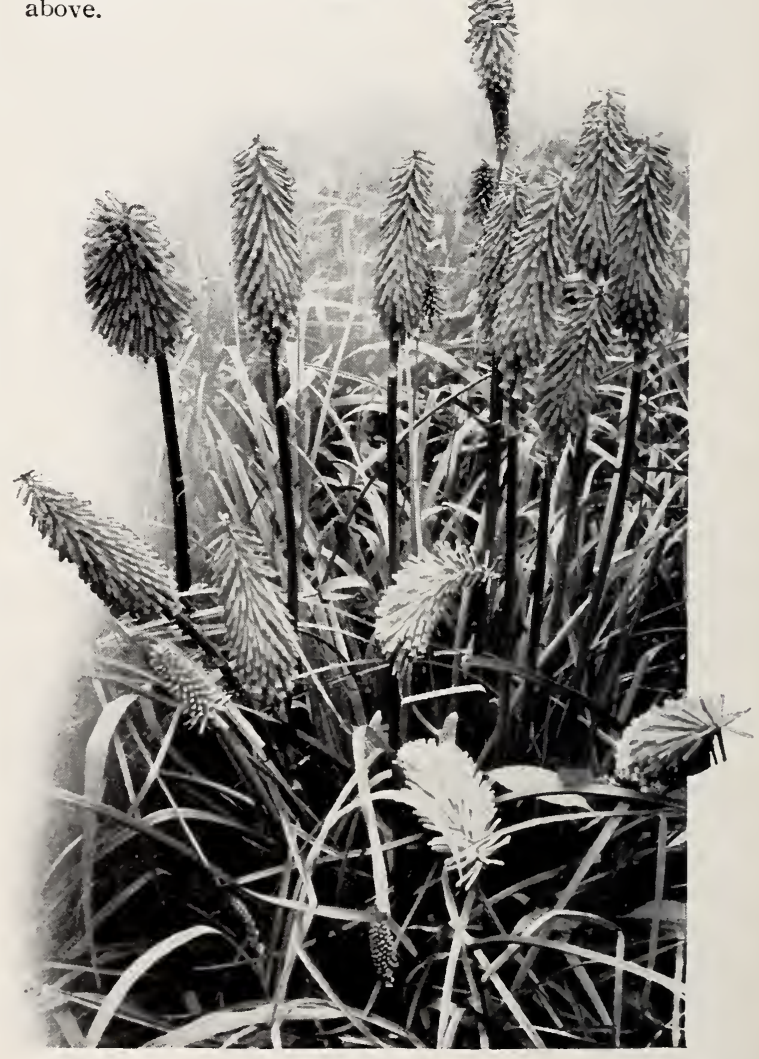

Tritoma pfitzeri (see page 57) 


\section{Ulmaria, continued}

Ulmaria purpurea (Spircea palmata). JAPANESE IEADOW SWEET. A superb species, with stems and branches of deep purplish red, contrasting sharply with the rich green, deeply lobed leaves. The plant produces a fine clump of them, usually 2 to 4 feet high, and bearing clusters of leep pink or purple flowers.

U. rubra. QUEEN OF THE PRAIRIE. A beautiful species with very large and showy terminal clusters of pink flowers waving in summer from stems sometimes 6 feet high. Particularly effective for garden grouping.

Any of the above, strong plants, prepaid, $15 \mathrm{cts}$, each ; larger sizes, purchaser paying transportation, $15 \mathrm{cts}$. and 25 cts. each.

\section{Valeriana}

Valeriana officinalis. GARUEN HELIOTROPE. In the older gardens this was a much-prized plant, not only for the spicy fragrance of its large clusters of small pink flowers, but for their value in bouquets. The plant is vigorous, spreading rapidly and soon forming fine clumps. The flowers appear abundantly, on tall stems, in spring and summer. Strong plants, prepaid, I5 cts. each; larger sizes, purchaser paying transportation, I5 cts and 25 cts.. each.

\section{Vernonia}

Vernonia noveboracensis. IRONWEED. The rich purple, brush-like blossoms of the Vernonia, held rigidly erect in open cymes upon their tall stalks in late summer and autumn, cannot fail to attract the eye that loves rich color and distinctive form. Each separate cluster is about an inch long and composed entirely of small tubular flowers, the many small clusters forming a rich array when grouped. The plant has long lanceolate leaves to further ornament its stem, and is in place in the background of borders, in wild gardening, or for grouping among shrubs. Strong plants, prepaid, I5 cts. each; larger sizes, purchaser paying transportation, $15 \mathrm{cts}$. and $25 \mathrm{c}$.

\section{Veronica - The Speedwells}

The taller species of the Speedwells have long, slender flower-spikes, composed of many small, deep blue flowers. They are among the best border plants, spending their rich color constantly from May until frosts. The dwarf species are also charming and fairly smothered with lovely blue flowers in spring.

Veronica longifolia subsessilis. JAPANESE SPFEDWEI. BI.UE JAY Flower. The tall, leafy stems of this elegant species end in deep blue flower-spikes sometimes a foot long. The habit is neat and robust, a good plant forming a number of stems 2 or 3 feet in height and waving all summer its long plumes of intense blue. Strong plants, prepaid, 25 cts. each ; larger sizes, purchaser paying transportation, $25 \mathrm{cts}$. and $35 \mathrm{cts}$. each.

V. rupestris. ROCK SPEEDWELL. Small and dainty, growing only 4 or 5 inches high, with thickly matted deep green foliage, hidden in spring under clouds of bright blue blossoms. An especially fine rock-cover or edging plant.

V. spicata. EUROPEAN SPEEDWELL. Flowers violetblue, in long slender spikes through summer. The densely disposed rich green leaves are an inch or two in length, the flower-stems $1 / 2$ to 2 feet tall.

Any of the Speedwells, unless otherwise noted, strong plants, prepaid, 15 cts. each; larger sizes, purchaser paying transportation, $15 \mathrm{cts}$. and $25 \mathrm{cts}$. each.

\section{Vinca $\cdot$ Periwinkles}

Vinca major. LARGER PERIWINKLE. A handsome trailing plant, with deep green, rounded, glossy leaves, strung in opposite pairs on long slender stems. Its large. salver-shaped flowers of light blue appear in spring or early summer and contrast beautifully with the rich leaves. Its most familiar use is in garden vases, window boxes and in rock gardens. In mild climates it makes a capital ground cover, but is not so hardy as the smaller-leaved species.

V. minor, CoMmoN PERIWINKLE, OR TRAILING MYRTLE. A hardy and delightful little evergreen trailer, closely associated with fine old gardens. Its clear blue flowers appear among the dark leaves as early as the Violets in spring, and its stems delight to spread their glossy lengths in cool, shaded places, forming a dense carpet of shining green. It endures denser shade than most creeping plants and is recommended for border-

Thank you for the plants, which came in good condition and are now snugly in their places. Your catalogues are among the most fascinating books I've seen this summer, and my hope is some day to see the nursery itself. WVishing you great success, I am, yours, John J. Llovd, Big Stone Gap, Va., December 2, 1909. 


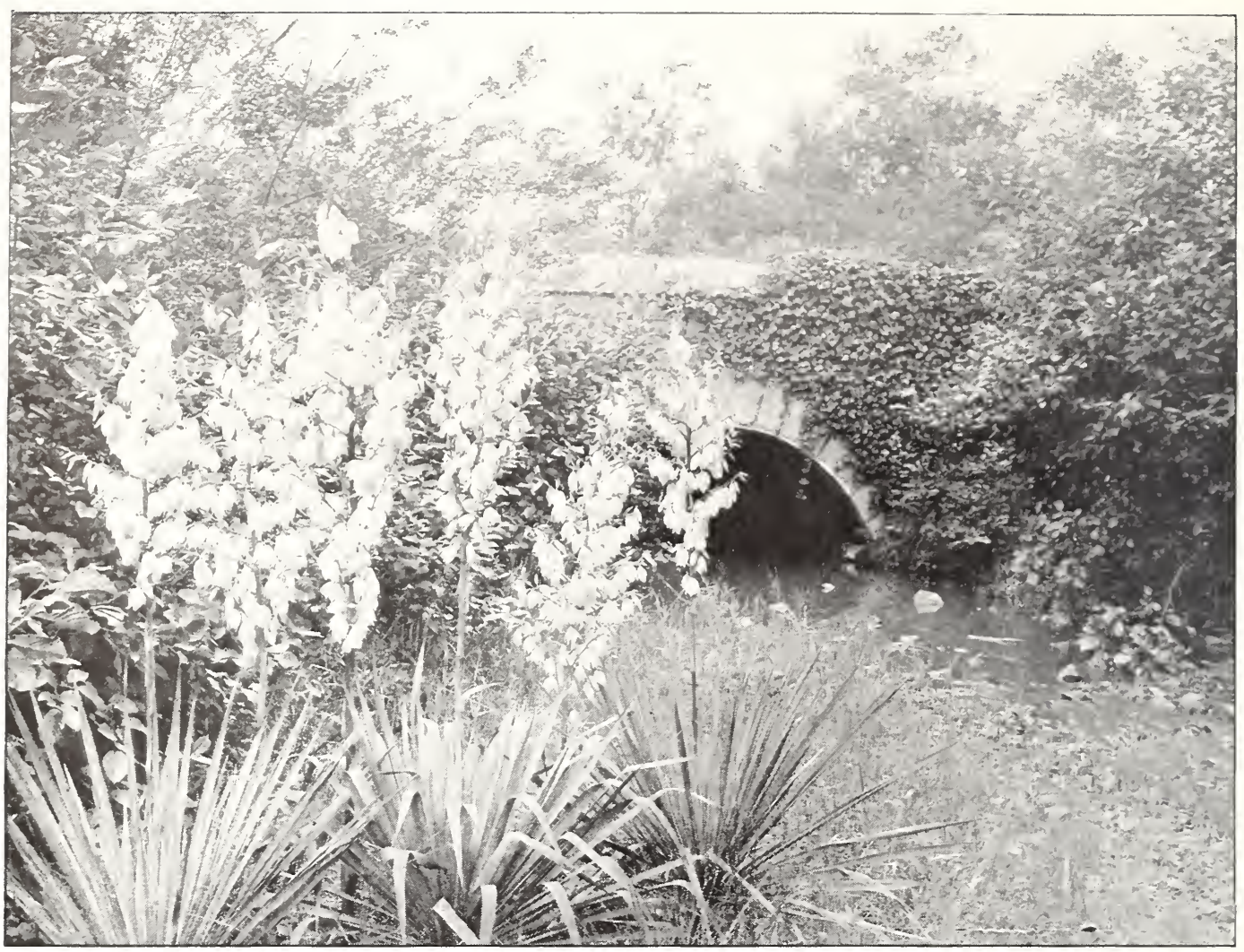

The stately spires of Yucca filamentosa

Viola, continued

I Tola odorata-but its double form which is also quite fragrant and hardy. Either form of the above, strong plants, prepaid, I5 cts. each; larger sizes, purchaser paying transportation, $15 \mathrm{cts}$, and $25 \mathrm{cts}$. each.

\section{Yucca}

Yucca filamentosa. ADAM's NeEdLE, BEAR Grass. From beds or belts of Yuccas the coldest of our states may have fine tropical-flower effects in summer and broad-leaved everoreen richness in winter. It has the largest flower-spike among perennials, its stateiy spires of large, lily-like blossoms frequently measuring 4 feet in height, sometimes 6 feet. These flowers are creamy white drooping and massed in hundreds on tall, branching stems, giving, in a moonlit garden, a broad flash of white, like that of marble columns or statuary.
Yucca filamentosa, continued

The plant is native to our Atlantic States and very hardy; vigorous, too, and delighting in dry, hot situations where other broad-leaved evergreens sometimes decline to flourish, and keeping green through winter its wide circles of stiff, lance-like leaves. Along their edges these have odd, curling white threads running down from the sharp point and probably suggesting the popular name. Strong plants, prepaid, 15 cts. each; larger sizes, purchaser paying transportation, i5 cts. and $25 \mathrm{cts}$. each.

Y. filamentosa variegata, VARIEGATED YUCCA, An odd and striking form of the last, having its leaves striped lengthwise with yellow and green. It is apparently quite as vigorous and permanent as the type and contrast with it, in grouping, gives bright effects. Strong plants, prepaid, 25 cts. each; larger sizes, purchaser paying transportation, 25 cts. and 35 cts. each.

\section{Testimonials}

The Vagnolias that I bought of you last spring are growing finely. Next spring I will wish to get some more. Yours truly, Thos. H. Rogers, Monmouth, Ill.

The plants you mailed to our address have duly arrived. We more than appreciate your promptness and we certainly will remember where to order next year. Thanking you very kindly, I remain, MIRS. ERnest F. Bisch, zoo Salena St., St. Louis, Mo., Lay II, Igog.

Several months ago I bought Chinese Privet hedge from your nursery and beg to say that the hedge has been doing beautifully, having grown something over three feet since planted. Yours truly, R. L. IICKINNEr, Columbia, Tenn., Aug. 7, 1909 .

Thank you very much for your kind and generons treatment. Very truly yours, MRS. A LBERT S. COOPER, Edehwald, Cassadaga, N. Y., May 22, I908.
Ny order of October oth arrived O. K, by exrress, today as per your letter of advice of October 19, ex quisitely packed, in perfect condition and entirely satisfactory. I hope they will be for years all their appearance promises they may be. IVe shall make further orders. Very truly, Johx Brivet Many Pines, Flat Rock, N. C., October 20, 1908.

Shrubs received in good condition. Thanks for prompt delivery and careful packing. HEXRY' ('BRIEX,

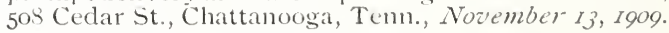

Your system of packing seems to be very nearly perfect and I am more than pleased with the plants as well. Very truly yours, WV. ScotT WAY, Easton, MId. November it, igog.

Everything came in fine condition and was very satisfactory. Yery truly yours, N. B. Dow Nivg, I262 Lawrence St., Brookland, D. C., November 29, 1909. 


\section{Testimonials, continued}

I have received the Roses called for in my order and the Crimson Rambler which you very kindly sent gratis. Allow me to thank you for the extra Rose and for the very nice stock you sent on all the items. I have never seen as carefully packed a shipment, and such careful packing means much at this end of the line. I shall hope to favor you with further orders as I need anything in your line. Very truly, A. WOODWARD STEPHeNs, Lewisburg, Pa., May I, I909.

The shrubs that I ordered arrived yesterday in fine condition. I regard this experience as unique, for each specimen was much farther advanced and far more vigorous than I had anticipated from the catalogue description. If they do not thrive I shall be sure the fault is not yours. Again, let me express my satisfaction and pleasure at the manner in which my insignificant order was filled. It will be larger next season. Yours sincerely, FloreNCE Lyox NORTON (Mrs. S. V. Norton), Valhalla-in-Aqueduct Road, Akron, O., Oct. I, 1909.

The plants arrived in good condition and are doing fine. Nany thanks for extra one sent. F. M. MARSH, I4 Io Ambert Ave., St. Louis, Mo., May 5, 1909.

The White Pine has just come and is set out. I am much pleased with the size and packing. We hope it will live and be an ornament to the campus. Respectfully, AxNa M. CoIT, Barium Springs, N. C., February 1,1909 .

I have received your shipment of evergreen trees and shrubs and am delighted with the plants. My gardener says they are the finest specimens he has seen and that they arrived in perfect condition. Accept my thanks for your liberality in sending so many. Very truly yours, W. T. IRwiN, Cincinnati, O., May 3,1909 .

I received the trees and was very much pleased with them. They came in excellent condition and I trust they will grow. Yours very truly, J C. HEFFERIEs, Gaffney, S. C., March 30, 1907.
My shipment of plants has arrived in good condition and I return thanks for careful packing and your gif of several dormant Roses. I am hoping that you wil remember me with your catalogue in the future. Very truly yours, DR. MARY HARLEY, Sweet Briar College, Sweet Briar, Va., March 16, 1907 .

The nursery stock ordered from you arrived yesterday in good condition. Thank you for the care you took in packing and sending, also for the extras. Yours truly, Lucy E. LEwis, Ashland, Mass., May 5, 1909.

The box of plants came day before yesterday and I am greatly pleased with them. Everything was fresh and in good condition. Very truly, MRS. C. R. BRECKFNRIDGE, 504 N. I6th St., Fort Smith, Ark., December 23, 1909 .

The package of Honeysuckle vines has just arrived, and they look in such hardy condition and were done up in such a fine parcel, I must tell you of it. I have never received, from any nursery, an order so well done up. Thanks for the Hibiscus. Will you kindly send me your complete catalogue. MRS. J. C. How Ridgewood Farm, Old Mission, Mich., April 23, 1909.

My plants arrived, by mail, last night and I want to thank you for the admirable manner in which they were packed and the distinct manner in which they were labeled and for the size of the plants. They were very fresh and good. Yours and oblige, GEORGE HoLlis, I 28 Hollis St., South Weymouth, Mass., April 19, 1909.

I want to thank you for your prompt attention to my insignificant order. I never received plants in such excellent condition, nor so carefully packed. When I have another order I shall take pleasure in remembering you. I really cannot express my appreciation of the excellence of plants and your care in filling my order. Am sorry I did not give you my entire order instead of dividing it as I did. Respectfully yours, Mrs. H. N. Mills, 2433 Independence Boulevard, Kansas City, Mo , April 19, 1909.

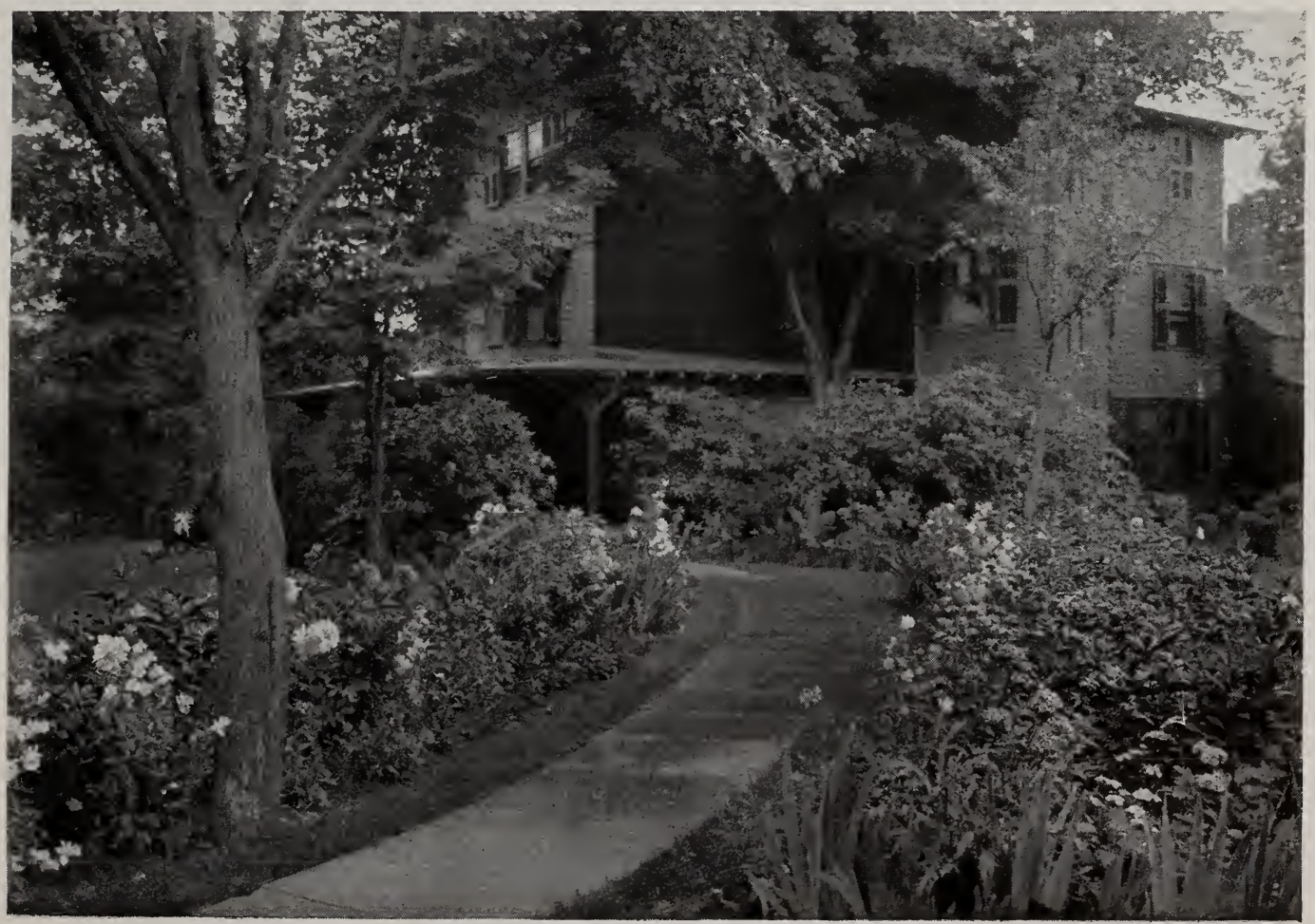

The happy result of a simple and informal planting 


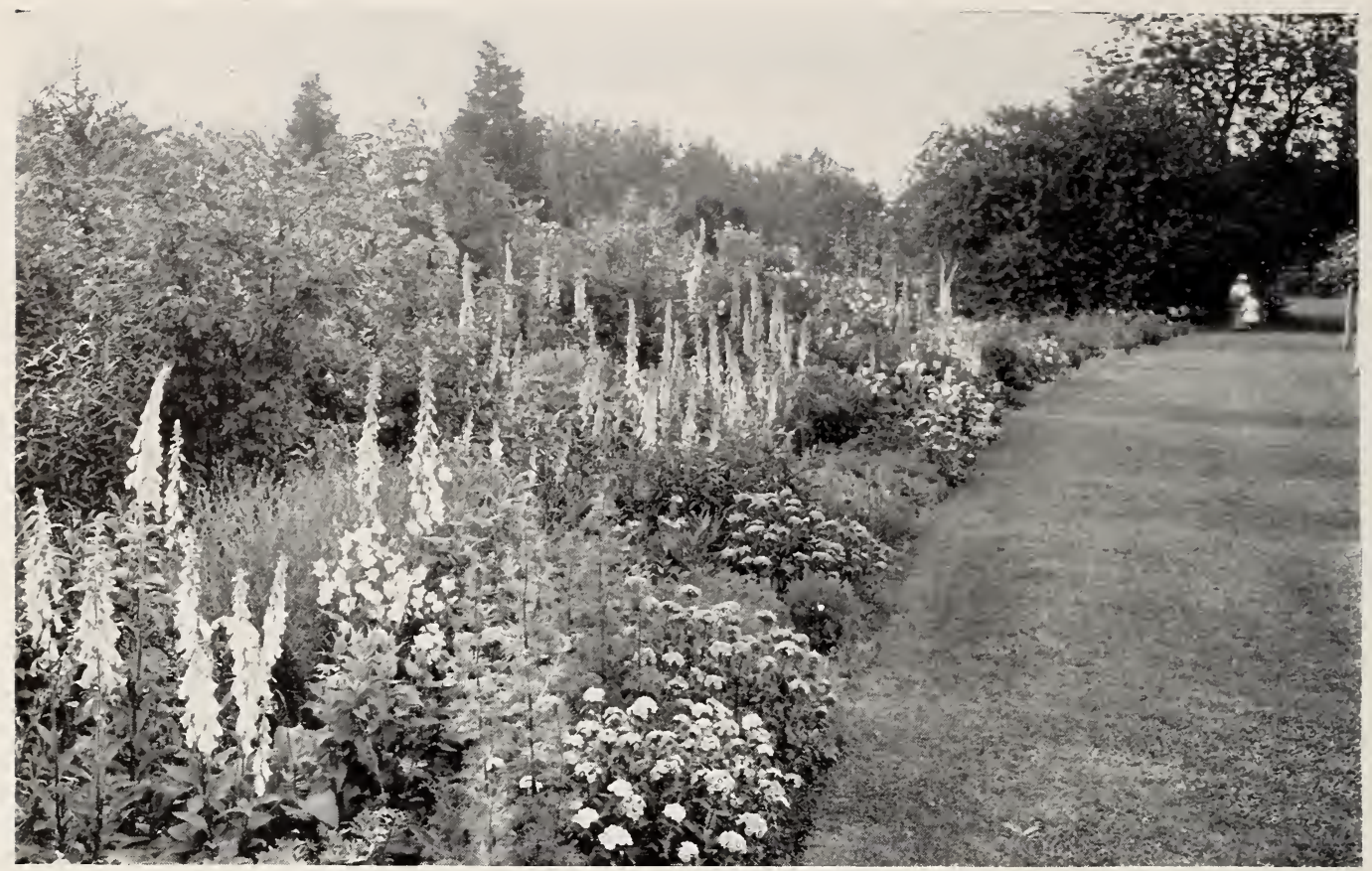

This reinstatement of Hardy Flowers rejoices the heart of the landscape gardener

\section{Sets of Hardy Garden Flowers}

The collections embrace some of the showiest and best of Herbaceous Perennials and are offered with a view of aiding the novice in securing garden flowers that are famous for their beauty. For convenience in ordering, patrons may designate by key letter as indicated.

Twenty - five Herbaceous Perennials noteworthy for their great beauty and lavish display of flowers. Set L.

Aconitum napellus. Monk's-hood.

Anemone japonica. Japanese Windflower.

Chrysanthemum, Hardy Pompon.

Convallaria majalis. Lily-of-the-Valley.

Delphinium. Larkspur.

Dianthus plumarius. Scotch Pink.

Dicentra spectabilis. Bleeding Heart.

Dictamnus fraxinella. Fraxinella.

Digitalis purpurea. Foxglove.

Funkia subcordata. White Day Lily

Helianthus multiflorus flore pleno. Double Hardy Sunflower.

Hemerocallis flava. Lemon Lily

Hibiscus moscheutos. Rose Mallow.

Iberis sempervirens. Evergreen Candytuft.

Iris germanica. Fleur-de-Lis.

Iris laevigata. Japanese Iris.

Iris sibirica. Siberian Iris.

Lilium tigrinum splendens. Tiger Lily.

Paeonia sinensis. Peony.

Papaver orientale. Oriental Poppy.

Phlox paniculata. Garden Phlox

Rudbeckia. Golden Glow.

Sedum spectabile. Brilliant Stonecrop.

Tradescantia virginica. Spiderwort.

Yucca filamentosa. Bear Grass.

One each of the above, twenty-five in all, strong plants, prepaid, $\$ 3.50$; larger sizes, purchases paying transportation, $\$ 3.50$ and $\$ 5$.

Twelve Herbaceous Perennials selected for their wonderful durability and attractiveness. Set M.

Convallaria majalis. Lily-of-the-Valley.

Dianthus plumarius. Scotch Pink.

Dicentra spectabilis. Bleeding Heart.

Dictamnus fraxinella. Fraxinella.

\section{Set $M$, continued}

Hemerocallis flava. Lemon Lily.

Hibiscus moscheutos. Rose Mallow.

Iris sibirica. Siberian Iris.

Paeonia sinensis. Peony.

Papaver orientale. Oriental Poppy.

Phlox paniculata. Garden Phlox.

Rudbeckia. Golden Glow.

Sedum spectabile. Brilliant Stonecrop.

One each of the above, twelve in all, strong plants, prepaid, $\$ 1.75$; larger sizes, purchaser paying transportation, $\$ 1.75$ and $\$ 2.50$.

Twelve Herbaceous Perennials blooming in Spring and early Summer. Set N.

Adonis vernalis. Pheasant's Eye.

Aquilegia canadensis. American Red Columbine.

Convallaria majalis. Lily-of-the-Valley

Dianthus plumarius. Scotch Pink.

Dicentra spectabilis. Bleeding Heart.

Hemerocallis flava. Lemon Lily.

Iberis sempervirens. Evergreen Candytuft.

Iris germanica. Fleur-de-Lis.

Iris pumila. European Dwarf Iris.

Paeonia sinensis. Peony.

Papaver orientale. Oriental Poppy.

Phlox subulata. Moss Pink.

One each of the above, twelve in all, strong plants, prepaid, $\$ 1.75$; larger sizes, purchaser paying transportation, $\$ 1.75$ and $\$ 2.50$.

Twelve Herbaceous Perennials blooming in summer. Set $\mathbf{O}$.

Asclepias tuberosa. Butterfly IVeed.

Coreopsis lanceolata. Lance-leaved Tickseed.

Delphinium. Larkspur.

Digitalis purpurea. Foxglove.

Gaillardia grandiflora. Blanket Flower.

Hemerocallis thunbergi. Late-flowered Lemon Lily. 


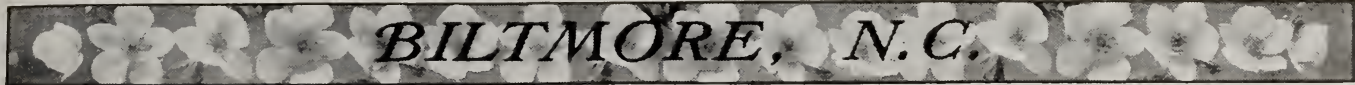

Set $O$, contintied

Iris laevigata. Japanese Iris.

Lychnis viscaria splendens. German Catchifly.

Phlox paniculata. Garden Phlox.

Physostegia virginiana. False Dragon Head.

Rudbeckia. Golden Glow.

Veronic longifolia subsessilis. Japanese Speedwell.

One each of the above, twelve in all, strong plants, prepaid, $\$ 1.75$; larger sizes, purchaser paying transportation, $\$ 1.75$ and $\$ 2.50$.

Twenty-five of the most popular Perennials Set P.

Althaea rosea. Hollyhock.

Anemone japonica. Japanese IVindflower.

Aquilegia. Columbine.

Campanula. Bellflower.

Convallaria majalis. Lily-of-the-Valley.

Chrysanthemum, Hardy Pompon.

Coreopsis lanceolata. Tickseed.

Delphinium. Larkspur.

Dianthus barbatus. Sweet William.

Dianthus plumarius. Scotch Pink.

Dicentra spectabilis. Bleeding Heart.

Digitalis purpurea. Foxglove.

Funkia subcordata. White Day Lily.

Gaillardia grandiflora. Blanket Flower.

Helianthus multiflorus flore pleno. Double Hardy Sun-

flower.

Hemerocallis flava. Lemon Lily.

Iris germanica. Fleur-de-Lis.
Set $P$, continued

Iris laevigata. Japanese Iris.

Lilium tigrinum splendens. Tiger Lily.

Paeonia sinensis. Peony.

Papaver orientale. Oriental Poppy.

Phlox paniculata. Garden Plilox.

Phlox subulata. Moss Pink.

Platycodon grandiflorum. Balloon Flower.

Pyrethrum hybridum. Persian Daisy.

One each of the above, twenty-five in all, strong plants, prepaid, $\$ 3.50$; larger sizes, purchaser paying transportation, $\$ 3.50$ and $\$ 5$.

Twelve of the most popular Perennials. Set R.

Althaea rosea. Hollyhock.

Anemone japonica. Japanese IVindflower.

Aquilegia. Columbine.

Delphinium. Larkspur.

Dianthus plumarius. Scotch Pink.

Dicentra spectabilis. Bleeding Heart.

Helianthus multiflorus flore pleno. Double Hardy Sunflower.

Hemerocallis flava. Lemon Lily.

Iris germanica. Fleur-de-Lis.

Paeonia sinensis. Peony.

Papaver orientale. Oriental Poppy.

Phlox paniculata. Garden Phlox.

One each of the above, twelve in all, strong plants, prepaid, $\$ 1.75$; larger sizes, purchaser paying transportation, $\$ 1.75$ and $\$ 2.50$.

The plants arrived in good condition yesterday. Yours truly, Louis JAck, Moylan, Pa., October 6, 1909.

The plants arrived in very good condition. Kindly accept my thanks. Respectfully yours, Mrs. WALTER M. Wellias, The Homestead, Clinton, Conn., May $18,1908$.

The shrubs, which I ordered some time since, arrived in good condition. Yours truly, Mrs. H. WILsON, 4630 Indiana Ave., Chicago, Ill., September $30,1909$.

The plants have arrived in excellent condition and I wish to thank you for your prompt attention to our order. Very truly yours, DANiel FAIRChILD, Agricultural Explorer in Charge, U. S. Department of Agriculture, Bureau of Plant Industry, Washington, D. C., November $20,1908$.

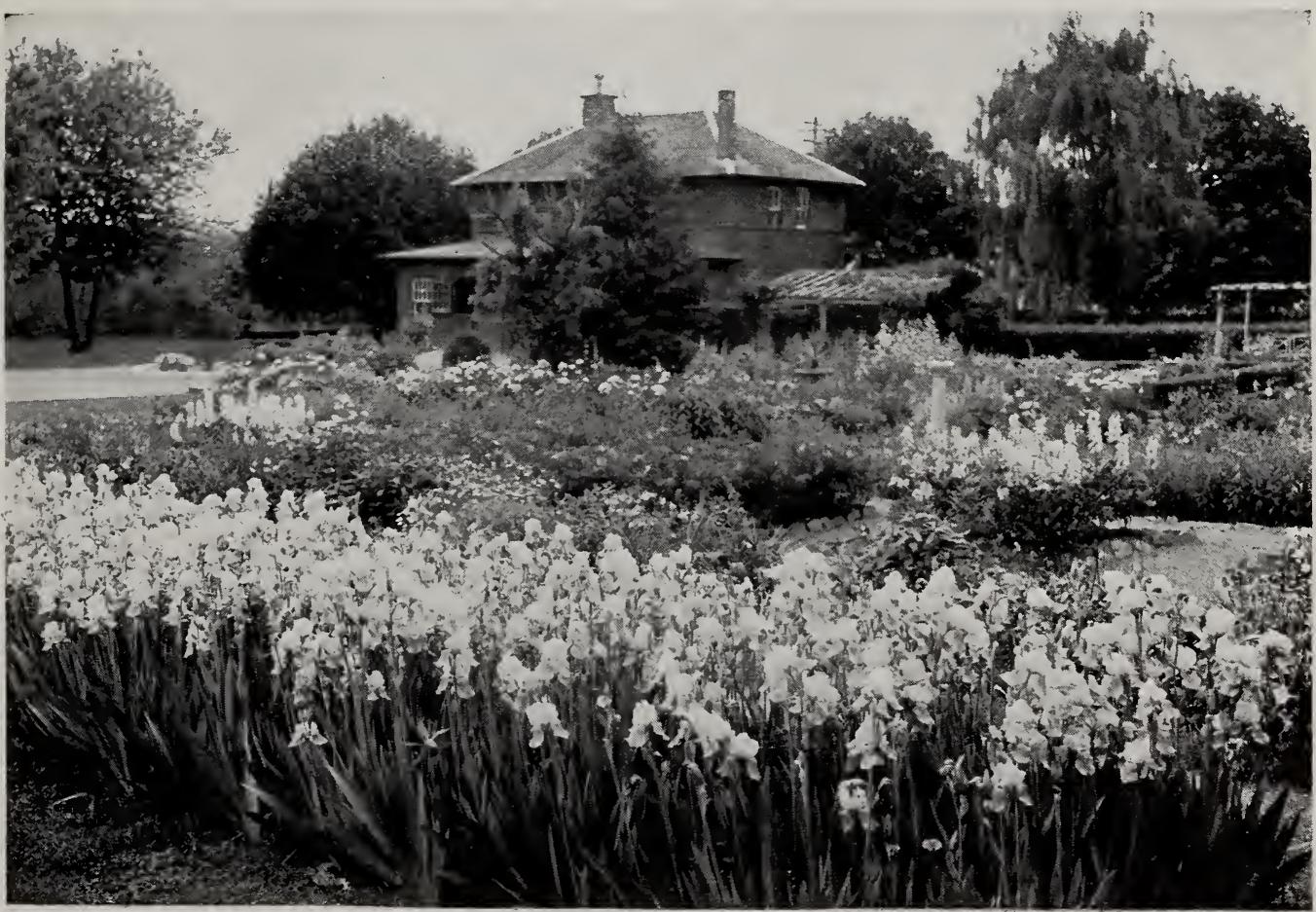

The joy of a garden is worth ten times its cost! 


\section{INDEX}

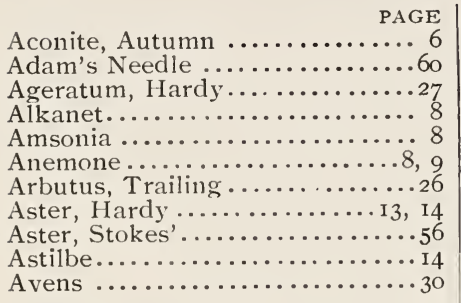

Baby's Breath...................30

Balloon Flower...............50

Balm, Bee ..................... 4.3

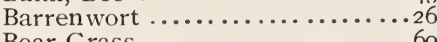

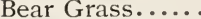

Bear's Breech ...............5, 6

Beard Tongue ............... 47

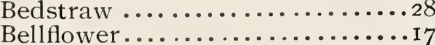

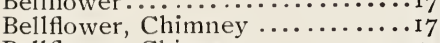

Bellflower, Chinese ............ 50

Blanket Flower ................28

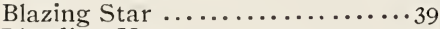

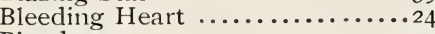

Bloodroot .................. 53

Blue Bells..........................

Blue Bells of Scotland............ 7

Blue Jay Flower ............. 59

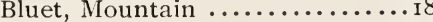

Bugle Vine ................ 7

Buttercup.................. $5^{2}$

Butterfly Weed............. I2, I3

Cactus, Hardy ................ 45

Campion, Rose ............. 7

Canterbury Bells ...............

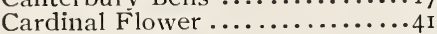

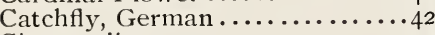

Chamomile ................ 9

Chamomile, False.............. 6

Christmas Rose...................

Chrysanthemum, Hardy Pompon

Cinquefoil $\ldots \ldots \ldots \ldots \ldots \ldots \ldots \ldots \ldots \ldots \ldots \ldots \ldots \ldots \ldots$

Clematis, Herbaceous ........20, 2 I

Colt's Foot ................... 88

Columbine................. Io, I I

Coneflower, Purple ............... 6

Coneflower, Yellow ............. $5^{2}$

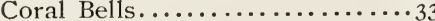

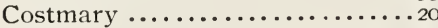

Cowslip .....................

Cowslip, Virginian ............

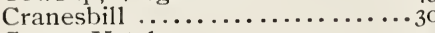

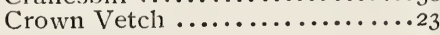

Daisy, English ........... I4, I6

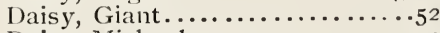

Daisy, Michaelmas............... 3

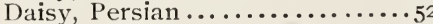

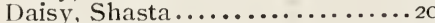

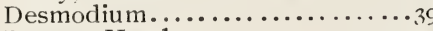

Dragon Head .............49, 50

Feather Fleece, Mountain ......55

Flag, Blue .............................

Flame Flower ............. 57

Flax, Perennial .............. II

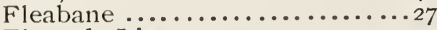

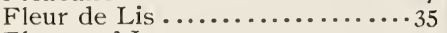

Flower of Jove............. 7

Forget-me-not ..............44

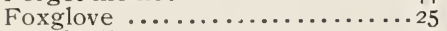

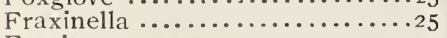

Fumitory .................. 33
PAGE

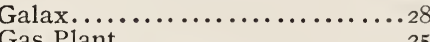

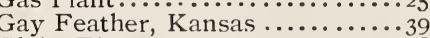

Globe Flower.........................

Gloxinia, Hardy ................

Goat's Beard .................. 2

Gold Tuft ................. 8

Golden Glow ................ . . 52

Goldenrod ....................55

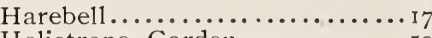

Heliotrope, Garden ............59

Hibiscus, Crimson-eyed ........34

Hollyhock..................

Houseleek.................. 55

Hudsonia ......................

Indigo, Blue .................. I4

Iris $\ldots \ldots \ldots \ldots \ldots \ldots \ldots \ldots . . . \ldots \ldots 5^{-37}$

Ironweed ....................59

Jacob's Ladder ............... 50

Joe Pye Weed ...............27

Lamp Flower...............42

Larkspur ...................

Lavender Cotton ..............53

Lavender, Sea.............. 55

Lavender, True...............

Leadwort ................... 18

Leopard's Bane................26

Lespedeza ................. 39

Lily, Blackberry ................

Lily, Hardy Garden .........39-4I

Lily, Lemon .................. 33

Lily, Orange....................

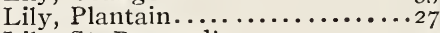

Lily, St. Bernard's..............

Lily, St. Bruno's ..............

Lily, White Day $\ldots \ldots \ldots \ldots \ldots \ldots 28$

Lily, White Wood ............57

Lily, Yellow Day ...........32, 33

Lily-of-the-Valley .............. II

London Pride ...............42

Loosestrife.................442

Loosestrife, Rosy ..........42, 43

Lungwort.................43

Lupine ....................

Mallow, Poppy .............. 6

Mallow, Rose ..............33, 34

Maltese Cross.................42

Marguerite, Hardy Golden ....... Io

Marigold, Marsh........... 6 , I7

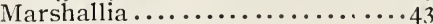

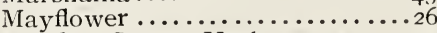

Meadow Sweet, Herbaceous ....5.59

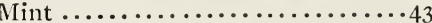

Moneywort ..................42

Monk's-Hood ................. 6

Moss Pink

Mullein Pink ............... 7

Myrtle, Trailing ..............59

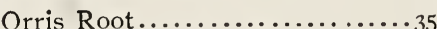

Ox-eye, Everblooming ..........32

Peach Bells .................. I7

Pea, Perennial ..............................

Pear, Prickly ................ 45

Peony .................. 45 $45^{-47}$

Peppermint ...................44

Periwinkle.................. 59

Pheasant's Eye..............6, 7

Phlox ...................44-49

Piney.....................45-48

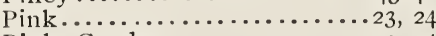

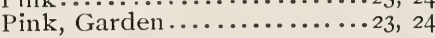

Pink, Moss .... PAGE

Pink, Mullein .............................

Pink, Saxifrage ..................59

Polyanthus ...................

Polygonum .....................

Poppy Nallow ................. 6

Poppy, Oriental ............47

Poppy, Plume ............... 6

Primrose, Alpine .............. I

Primrose, English ............

Primrose, Evening............44

Queen of the Meadow ............58

Queen of the Prairie ........... 59

Red-Hot Poker ................57

Rock Cress ................... II

Rock Rose...................30

Rocket, Sweet ................. 33

Rockfoil .................... 53

Rose Campion ............... 7

Rose, Christmas ................ 32

Rose, Rock .....................

Rosemary .................. 52

Rue, Goat's..................28

Rue, Meadow................... 56

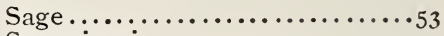

Sanguinaria $\ldots \ldots \ldots \ldots \ldots \ldots \ldots \ldots$
Saxifrage, Pink $\ldots \ldots \ldots \ldots \ldots$

Scabious.................... 54

Sea Thrift $\ldots \ldots \ldots \ldots \ldots \ldots \ldots \ldots$ II

Senna, American ............... 8

Shell Flower................. I9

Shooting Star $\ldots \ldots \ldots \ldots \ldots \ldots 25,26$

Shortia ...................... 55

Snakebread, Purple ............ II

Snakeroot, Black .............. I9

Snakeroot, Button...$\cdots \cdots \cdots \cdots \cdot \cdots$

Snakeroot, White..............27

Sneezeweed.................... 30

Snow-in-Summer ............. 8

Soapwort $\ldots \ldots \ldots \ldots \ldots \ldots \ldots \ldots \ldots \ldots \ldots \ldots \ldots \ldots \ldots \ldots \ldots$

Southernwood.............. I I, 12

Spearmint ...................43

Speedwell .................... 59

Spiderwort $\ldots \ldots \ldots \ldots \ldots \ldots \ldots \ldots \ldots \ldots \ldots \ldots \ldots \ldots, 57$

Spirea, Herbaceous .......... $5^{8}, 59$

Spurge, Alleghany ............. 45

Spurge, Flowering ............27

Spurge, Japanese...$\cdots \cdots \cdots \cdots \cdot 45$

Stonecrop ................ 54, 55

Sundrops $\ldots \ldots \ldots \ldots \ldots \ldots \ldots \ldots . \ldots \ldots \ldots$

Sunflower, Perennial …........ 3 r, 32

Sweet William.................23

Sweet Woodruff ................13

Tansy .................. $6,{ }^{6}$

Tansy, Double-flowered White... 6

Tea, Oswego $\ldots \ldots \ldots \ldots \ldots \ldots \ldots, \ldots$

Thrift....................... II

Thyme ..................... 56

Tickseed .................. I I

Thoroughwort, Late-flowering ...27

Turtlehead ..................

Vetch, Crown................23

Violet, Dame's............... 33

Violet, Hardy Sweet $. . . \cdots \cdot 57,5^{8}$

Wake Robin .................. 57

WVall Pepper ...................54

White Cup ..................... 44

IVidow's Cross................... 54

IVindflower $\ldots \ldots \ldots \ldots \ldots \ldots \ldots, 9$

Woodruff, Sweet............... 3

Yarrow $\ldots \ldots \ldots \ldots \ldots \ldots \ldots$ 


\section{ORDER}

THIS BLANK MATERIALLY AIDS IN FILLING YOUR ORDER PROMPTLY AND ACCURATELY

\section{BILTMORE NURSERY Biltmore, North Carolina}

Send

State if you have selected prepaid sizes of plants, or those upon which you will assume transportation charges

To.

P. O. Box, Street

or Rural Delivery

Post Office

County

State

Name of Railway

Station or

Express Office

Only when different from Post Office
Date

AMOUNT ENCLOSED

Cash.

Draft .

P. O. or Exp. Order

Stamps

If goods are wanted by express C. O. D., 25 per cent of the amount of the order must be paid in advance.

\section{RECORDED}

Forward Now or About

The prices in the Catalog are net. To avoid confusion, please exiend the price of each item.

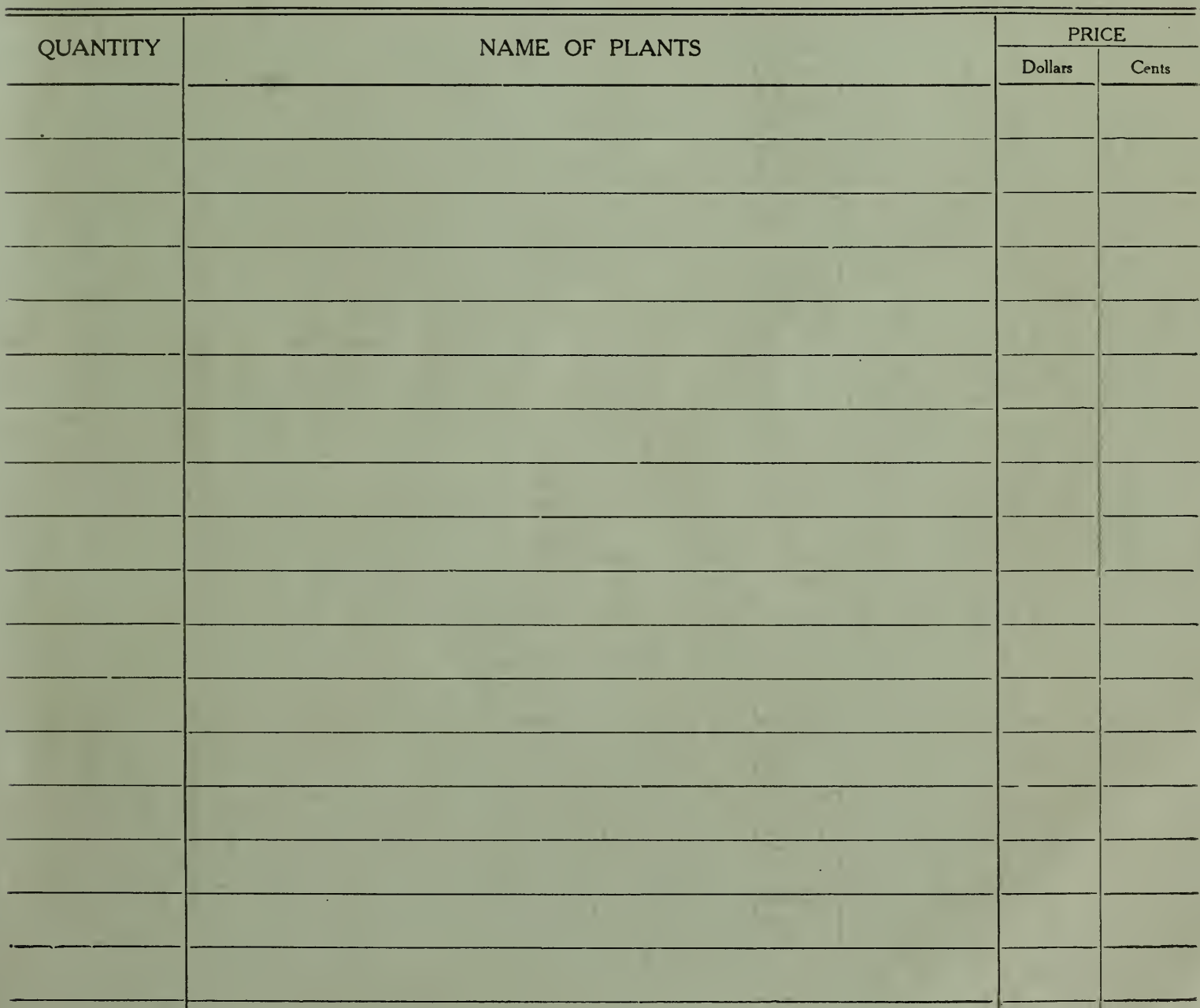


6.

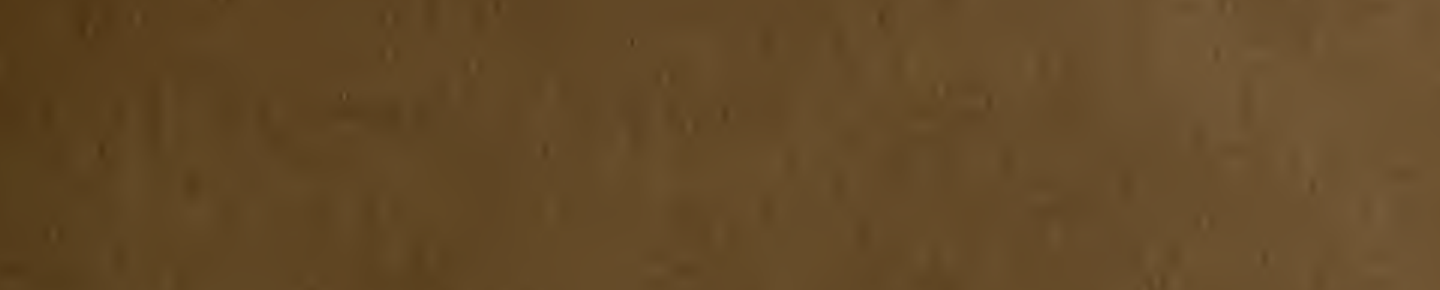
i)

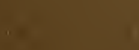

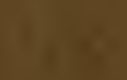

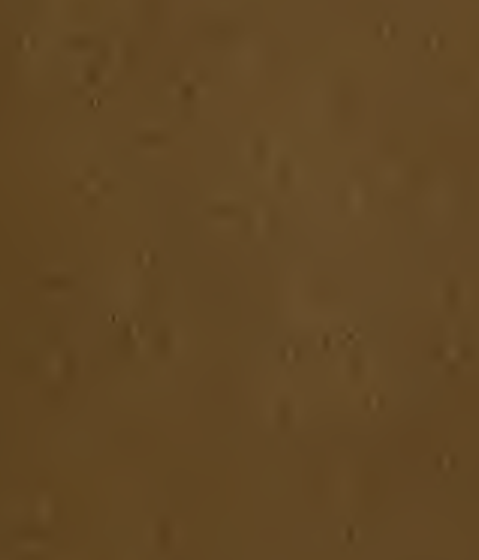

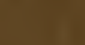

$$
\begin{aligned}
& \text { and }
\end{aligned}
$$

$$
-x+1,
$$$$
\text { s }
$$

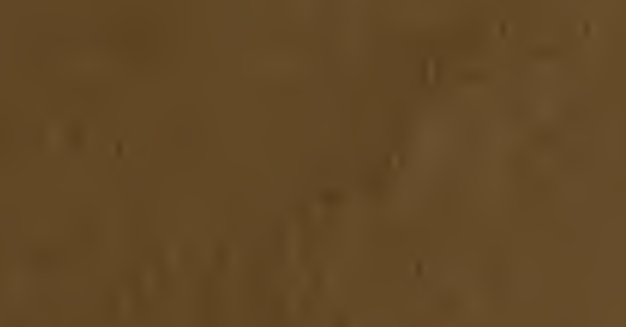

$$
\begin{aligned}
& \text { a } 1
\end{aligned}
$$

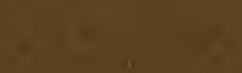

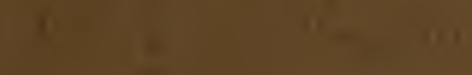




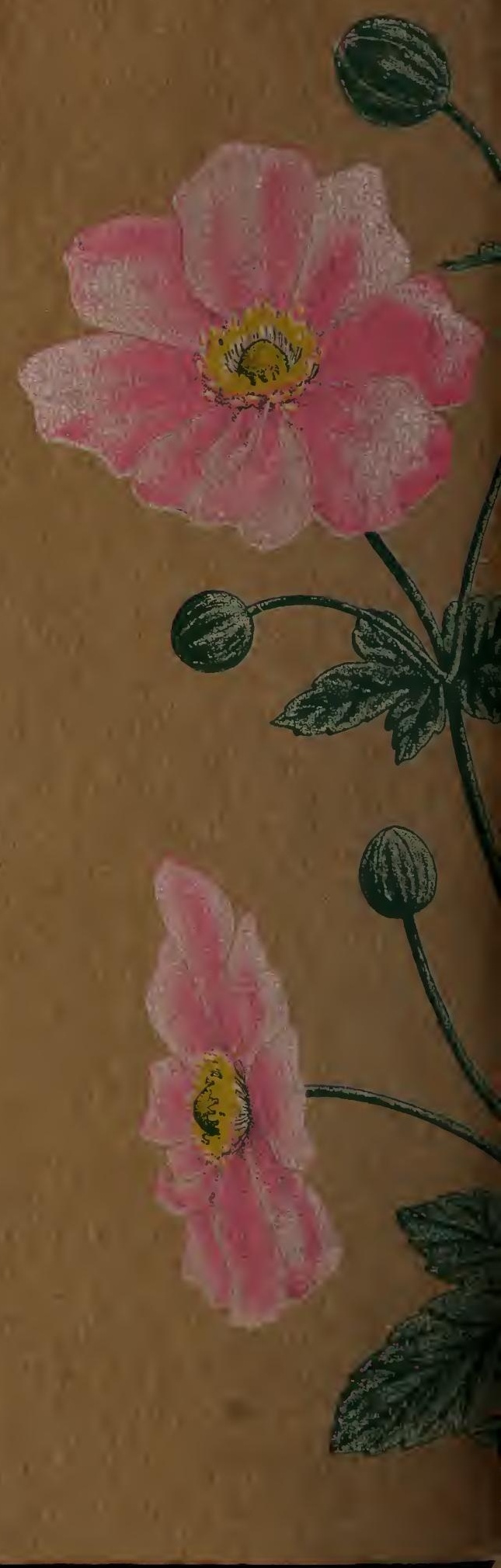

